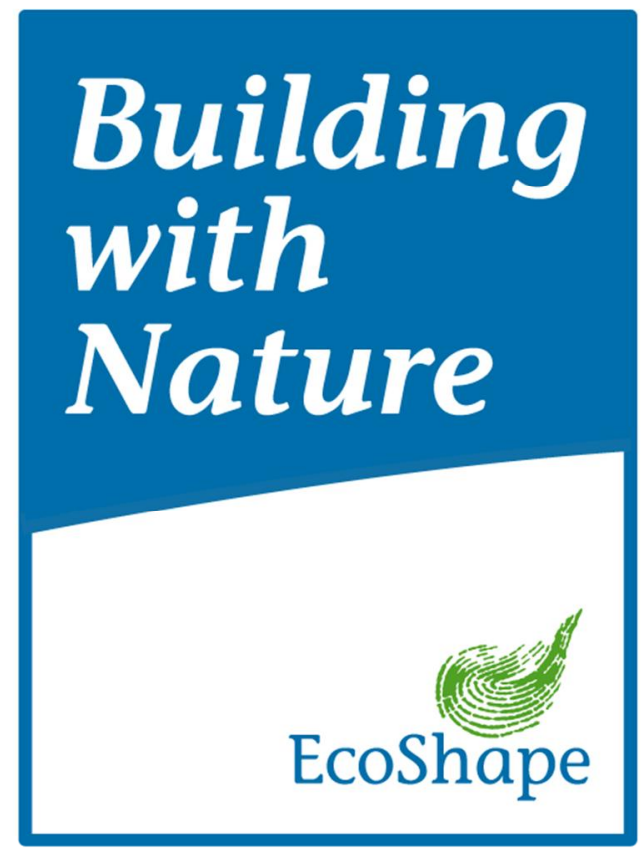

\title{
Building with Nature pilot Zandmotor Friese IJsselmeerkust
}

Hoe effectief is de zandmotor als ecodynamische strategie voor het versterken van de Friese IJsselmeerkust?

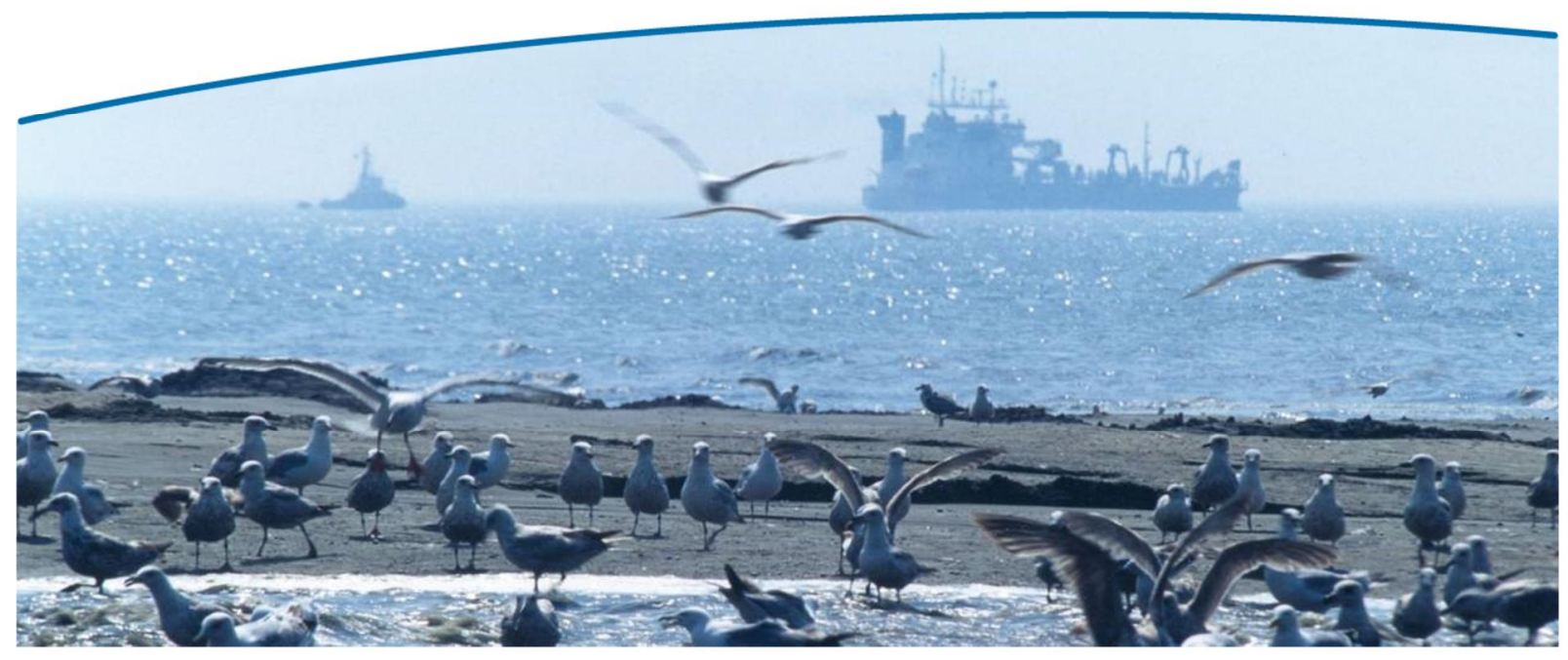





\section{Building with Nature pilot Zandmotor Friese IJsselmeerkust}

Hoe effectief is de zandmotor als ecodynamische strategie voor het versterken van de Friese IJsselmeerkust?

$1220414-000$ 

Titel

Building with Nature pilot Zandmotor Friese IJsselmeerkust

Project

Kenmerk

Pagina's

1220414-000

1220414-000-BGS-0003

51

\begin{tabular}{cllll}
\hline Versie Datum & Auteur & Organisatie Paraaf Review & Paraf Goedkeuring \\
\hline juni 2016 & Ane Wiersma & Deltares & \\
\hline & Tim van Hattum & Wageningen UR \\
\hline Marieke de Lange & Wageningen UR \\
\hline Erik van Slobbe & Wageningen UR \\
\hline
\end{tabular}

\section{Status}

definitief

Alterra-rapport nummer: 2706

ISBN: 978-94-6257-835-7

DOI: http://dx.doi.org/10.18174/383749 



\section{Inhoud}

1 Inleiding 1

1.1 Inleiding 1

1.2 Opgaven Friese IJsselmeerkust 1

1.3 Building with Nature als mogelijke oplossing 3

1.4 Pilots zandmotor Friese IJsselmeerkust 4

1.5 Doel 4

1.6 Leeswijzer 5

2 Systeembeschrijving Friese IJsselmeerkust $\quad 7$

2.1 Morfologische ontwikkeling van de Friese IJsselmeerkust $\quad 7$

2.2 Eerdere ingrepen $\quad 12$

2.3 Algemeen beeld van de aquatische vegetatie langs de Friese IJsselmeerkust 16

2.4 Algemeen beeld terrestrische vegetatie Workumer buitenwaard 16

3 Building with Nature aanpak Friese IJsselmeerkust 19

3.1 Wat is Building with Nature? 19

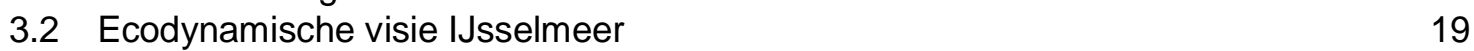

3.3 Ecodynamische bescherming Friese IJsselmeerkust 20

$\begin{array}{ll}3.4 \text { Het concept zandmotor } & 21\end{array}$

4 Werkwijze pilots Zandmotor Friese IJsselmeerkust 23

4.1 Drie Pilots Friese IJsselmeerkust 23

4.2 Monitoringsprogramma 23

$\begin{array}{lll}4.3 & \text { Zandmotor bij Workum } & 25\end{array}$

4.4 Zandmotor bij Oudemirdum 26

$\begin{array}{ll}4.5 & \text { Pilot Hindeloopen } \\ & 27\end{array}$

5 Resultaten monitoring zandmotoren Friese IJsselmeerkust 33

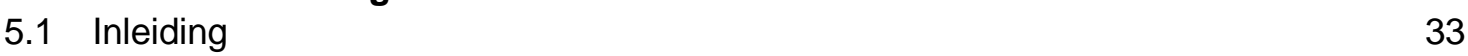

5.2 Resultaten pilot zandmotor Workum 33

5.2.1 Hoe verspreidt het zand zich en hoe snel beweegt het zand? 33

5.2.2 Effecten op de kust 34

5.2.3 Effecten van de palenrij 36

$\begin{array}{lll}\text { 5.2.4 Effecten op aquatische vegetatie } & 36\end{array}$

$\begin{array}{lll}5.2 .5 & \text { Effecten op terrestrische vegetatie } & 39\end{array}$

5.3 Resultaten pilot zandmotor Oudemirdum 41

5.3.1 Hoe verspreidt het zand zich en hoe snel beweegt het zand? 41

5.3.2 Effect op aquatische ecologie 42

6 Discussie en conclusies $\quad 45$

6.1 Geleerde lessen 45

6.1.1 Het morfologische systeem van de Friese IJsselmeerkust 45

6.1.2 Conclusies pilots zandmotor Workum en Oudemirdum 45

6.1.3 Zandmotoren, palenrijen en lage eilanden voor de kust 46

$\begin{array}{lll}6.2 & \text { Opschaling } & 48\end{array}$

$\begin{array}{lll}6.3 & \text { Vervolgstappen } & 50\end{array}$ 
7 Referenties

\section{Bijlage(n)}

\section{A Bijlage A}

A-1

Rapport Stand van zaken monitoring zandmotoren langs de Friese IJsselmeerkust

B Bijlage B

B-1

Monitoring of the vegetation development in the Workumer buitenwaarden for assessing the effects of sand nourishment 


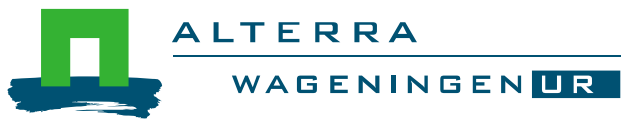

\section{Management samenvatting}

Dit rapport beschrijt de resultaten van de monitoring van de Building with Nature pilot langs de Friese IJsselmeerkust in de periode $2011 \mathrm{t} / \mathrm{m}$ 2015. De monitoring van de experimenten met zandmotors bij Workum en Oudemirdum is gericht op het begrijpen van het gedrag van de zandmotor, de effecten op de kust en op de ecologie. De monitoring loopt door tot en met 2017, dit rapport is dan ook te beschouwen als een tussenstand. Omdat er in 2016 een MIRT-pre-verkenning start met als doel het vaststellen van compenserende maatregelen langs de Friese IJsselmeerkust voor het veranderende peilregime van het IJsselmeer is het opportuun om nu met deze tussenstand van monitoringsresultaten te komen. In 2017 worden de definitieve resultaten gepubliceerd.

\section{Achtergrond}

Langs de Friese IJsselmeerkust liggen waardevolle buitendijkse gebieden. Deze buitendijkse gebieden zijn kwetsbaar en kunnen achteruitgaan door het nieuwe peilbeheer, zoals dat in het Deltaprogramma wordt voorgesteld. Het zogeheten flexibel peilbeheer dat nodig is voor het vergroten van de buffervoorraad zoetwater vereist extra bescherming van buitendijkse gebieden. Tien centimeter peilstijging betekent dat ruim honderd hectare land onder water komt te staan. Zonder aanvullende maatregelen zullen buitendijkse gebieden door erosie verdwijnen. De opgave is om de IJsselmeerkust dermate veerkrachtig te maken, dat het de negatieve gevolgen van het verhoogde waterpeil op kan vangen. Ook als het waterpeil in de toekomst nog verder omhoog gaat.

De belangen van gemeenschappen langs de Friese IJsselmeerkust zijn groot omdat de buitendijkse gebieden grote waarden vertegenwoordigen voor natuur, recreatie en de waterveiligheid. Daarom hebben de betrokken Friese partijen in 2010 besloten te investeren in innovatief kustbeheer. In het Building with Nature project de Zachte Zandmotor onderzoekt Ecoshape in hoeverre natuurlijke processen zoals wind en zandtransport ingezet kunnen worden voor een duurzame kustbescherming. Hierbij wordt onderzocht hoe de principes van Building with Nature toepasbaar zijn voor de Friese IJsselmeerkust. De kennis die in dit project wordt opgedaan vormt een belangrijke bouwsteen voor het ontwikkelen van een strategie voor duurzame kustbescherming en het versterken van de ecologische kwaliteit van de hele Friese IJsselmeerkust.

\section{Pilots zandmotor Friese IJsselmeerkust}

Het project de Zachte Zandmotor langs de Friese IJsselmeerkust bestaat uit praktijkonderzoeken naar een robuuste kustverdediging door natuurlijke processen. Daarvoor zijn op 2 proeflocaties zandsuppleties aangelegd: de pilots Workumerwaard en Oudemirdum. Voor de locatie Hindeloopen is gekozen voor het uitvoeren van een modelstudie. 

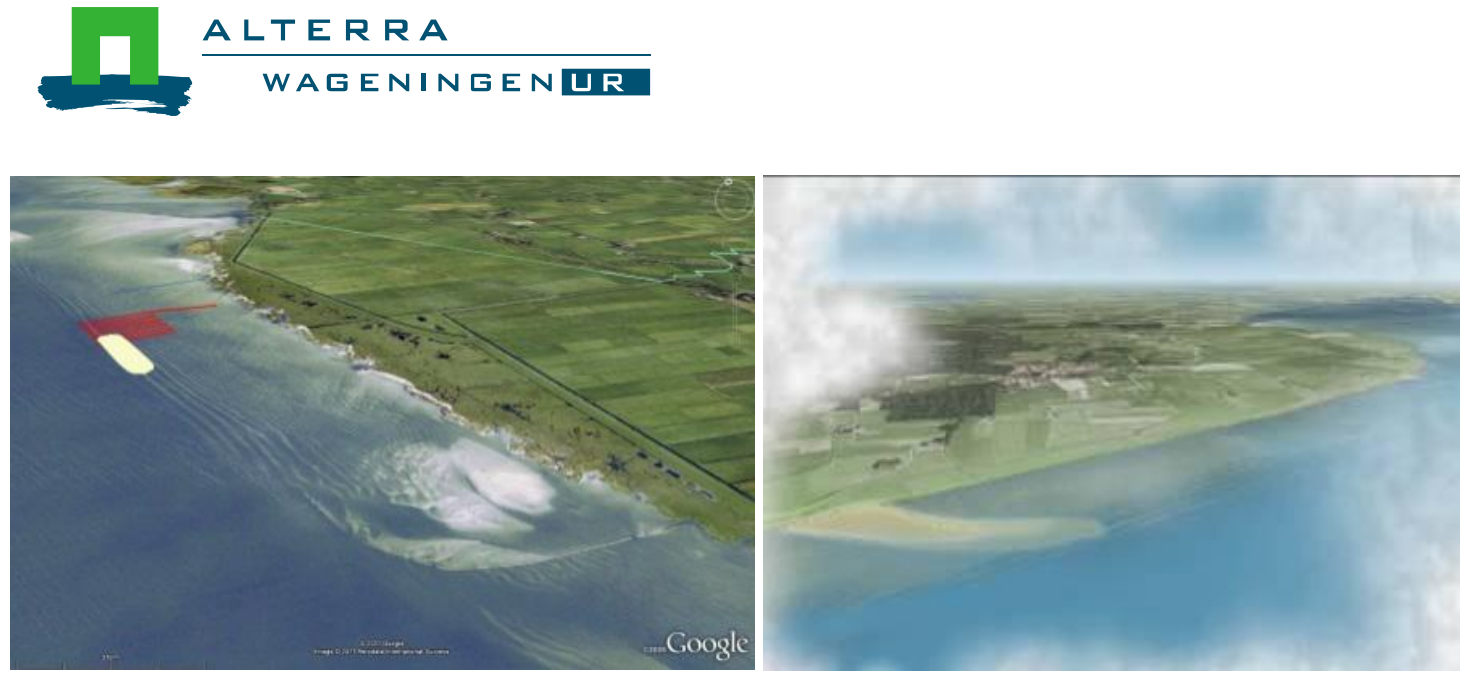

Afbeelding: Zandsuppletie bij de Workumerwaard (links) en Oudemirdum (rechts)

Er wordt onderzocht of een zandmotor kan leiden tot een duurzamere, goedkopere en ecologisch robuustere kustbescherming, waarbij men uitgaat van de inzet van natuurlijke processen bij de verdediging van de kust in relatie tot toekomstige peilstijging en peilfluctuaties. Om dit te testen is een uitgebreid monitoringprogramma opgezet die de effecten van de zandmotoren op de kust volgt, monitort hoe het zand zich beweegt en hoe de ecologie zicht ontwikkelt. Hierbij staan de volgende vragen centraal:

- Is de zandmotor een effectieve, duurzame en ecologisch robuuste maatregel voor het versterken van de Friese IJsselmeerkust?

- Kan het concept van de zandmotor worden opgeschaald naar andere locaties langs de Friese IJsselmeerkust?

\section{Conclusies}

De belangrijkste voorlopige conclusies van de pilots met de zandmotor zijn hieronder samengevat:

- De monitoringsgegevens tot en met 2015 laten zien dat het gesuppleerde zand in Workum en Oudemirdum langzaam wordt verspreid en dat er dynamiek en sedimentverplaatsing in het gebied aanwezig is. In de experimenten is echter geen kustversterking door aanzanding waargenomen. Wel kan een suppletie op de ondiepe vooroever golven breken en daarmee golfaanslag op de kust verminderen. Dit effect is tijdelijk als gevolg van de waargenomen dynamiek.

- $\quad$ Bij suppleties in het dynamische gedeelte van de vooroever aan de rand van het IJsselmeer (zoals bij Workum) wordt het zand snel verspreid en wordt de kust niet versterkt. Het in stand houden van de ondiepe vooroever is echter wel van belang, omdat op de rand ervan de grootste golven breken.

- $\quad$ Landwaarts van de dynamische zone (zoals bij Oudemirdum) blijt het verspoelde zand langer liggen en wordt een luwte gecreëerd.

- De monitoringsresultaten tot nu toe tonen dat de Oudemirdum zandmotor (dicht bij de kust in een haakvorm) langer haar vorm en functie behoudt dan de Workumerwaard zandmotor. Geen van beiden hebben gezorgd voor aanzanding aan de kust.

- De zandsuppleties leiden tot dissipatie van golfenergie. Ook de natuurlijke zandruggen op de rand van de vooroever dragen bij aan de golfdissipatie. Of de extra dissipatie door de zandsuppleties daadwerkelijk leidt tot afname van golfenergie op de kust in de luwte ervan is niet vastgesteld op basis van de metingen. Er is geen zichtbaar positief of negatief effect op de kust van de Workumerwaard sinds de aanleg van de zandmotor. Hieruit kan geconcludeerd worden dat de golfdissipatie door de zandsuppleties geen waarneembaar remmend effect heeft gehad op de eroderende werking van golfaanval op de kust. 
- De zandsuppleties onder water (dynamische suppletie) hebben geen significant aantoonbaar positief of negatief effect op ecologie. Bij beide pilot locaties zijn er geen significant aantoonbare positieve of negatieve effecten waargenomen op de vegetatie onder water en boven water.

- De omvang van het volume en de schaal van beide zandmotor experimenten is beperkt; zo beperkt dat geen significante effecten op ecologie waargenomen. Het ligt in de rede te verwachten dat bij opschaling deze effecten wel gaan optreden.

\section{Building with Nature strategie Friese IJsselmeerkust}

In het algemeen kan worden gesteld dat de Building with Nature pilots veel inzicht hebben opgeleverd over de werking van het systeem en de potentie van ecodynamische maatregelen voor het duurzaam versterken van de Friese IJsselmeerkust. Eén van deze inzichten is dat voor de Friese IJsselmeerkust geldt dat de westkust is versneden door vaargeulen waardoor compartimentering optreedt. Hierdoor hebben maatregelen met zand weinig potentie. De zuidkust daarentegen is één aaneengesloten systeem waardoor ingrepen met zand hier wel potentie heeft. Op basis van de kennis en inzichten uit deze studie zijn in tabel 1 Building with Nature maatregelen opgenomen die kansrijk zijn om de Friese IJsselmeerkust duurzaam te beschermen. Aanbevolen wordt deze maatregelen in de MIRT-verkenning mee te nemen. Een van de adviezen is om inzicht te krijgen in het morfologisch en ecologisch systeem van de Friese kust door scenarios te ontwikkelen voor de Friese kust over 100 jaar waarin geen ingrepen of onderhoud zijn uitgevoerd. 
Tabel 1: Opschaling van Building with Nature maatregelen in het langs de Friese IJsselmeerkust

\begin{tabular}{|c|c|c|}
\hline Opgaven & Building with Nature maatregel & Opmerkingen \\
\hline $\begin{array}{l}\text { Duurzame } \\
\text { kustbescherming } \\
\text { in combinatie met } \\
\text { dynamische } \\
\text { natuur }\end{array}$ & $\begin{array}{l}\text { Zandmotor/dynamisch zandeiland ter } \\
\text { hoogte van het Vrouwenzand met als } \\
\text { doel om de Friese zuidkust te voeden } \\
\text { op de schaal van tientallen jaren en als } \\
\text { dynamisch eiland om natuurwaarden } \\
\text { in stand te houden. }\end{array}$ & $\begin{array}{l}\text { Dit vraagt afstemming met het } \\
\text { voornemen om grof zand langs de } \\
\text { zuidkust te winnen en om afdekkende } \\
\text { lagen van de winning en vrijkomend slib } \\
\text { in het systeem te brengen. } \\
\text { Onderzoek is nodig naar locaties en } \\
\text { mogelijke effecten op zandtransport en } \\
\text { ecologie. }\end{array}$ \\
\hline $\begin{array}{l}\text { Tegengaan van } \\
\text { erosie } \\
\text { buitenwaarden }\end{array}$ & $\begin{array}{l}\text { - } \quad \text { Palenrijen evenwijdig aan de kust } \\
\text { - } \quad \text { Zandmotoren dicht op de kust naar } \\
\text { het model van Oudemirdum }\end{array}$ & $\begin{array}{l}\text { Doel is om de golfenergie te } \\
\text { verminderen. } \\
\text { Zandinbreng aan de westkust zal } \\
\text { potentieel het baggerbezwaar van de } \\
\text { vaargeulen laten toenemen. Zorgvuldige } \\
\text { locatiekeuze is nodig. }\end{array}$ \\
\hline $\begin{array}{l}\text { tegengaan van } \\
\text { erosie stranden } \\
\text { Molkwerum, } \\
\text { Hindeloopen, It } \\
\text { Soal, Makkum, } \\
\text { Lemmer, } \\
\text { Oudemirdum. }\end{array}$ & $\begin{array}{l}\text { Lage eilanden van biezenmatten of } \\
\text { palenrijen op plekken met voldoende } \\
\text { dynamiek zodat een pionier strand } \\
\text { ontstaat en water zich kan verversen, } \\
\text { zodat er geen blauwalg komt, maar } \\
\text { niet teveel dynamiek zodat erosie } \\
\text { tegengegaan wordt. }\end{array}$ & $\begin{array}{l}\text { Met deze maatregel is alleen met } \\
\text { simulatie modellen geëxperimenteerd bij } \\
\text { Hindeloopen. Lokale ondernemers geven } \\
\text { de voorkeur aan bescherming van het } \\
\text { strand door geotubes, omdat er zo geen } \\
\text { obstakel tussen strand en meer ontstaat. }\end{array}$ \\
\hline $\begin{array}{l}\text { Versterken dijken } \\
\text { met natuurlijk } \\
\text { ingericht voorland }\end{array}$ & $\begin{array}{l}\text { Zandmotoren, oeverdijken, vooroevers } \\
\text { en/of palenrijen dicht op de kust. }\end{array}$ & $\begin{array}{l}\text { Om golven af te vlakken, zodat de } \\
\text { dijkhoogte kan verminderen. Langs de } \\
\text { Markermeerdijk tussen Enkhuizen en } \\
\text { Amsterdam worden om dezelfde reden } \\
\text { oeverdijken aangelegd. } \\
\text { In de BwN pilot Houtribdijk wordt de } \\
\text { effectiviteit van een zandige vooroever } \\
\text { met vegetatie onderzocht. }\end{array}$ \\
\hline $\begin{array}{l}\text { Overstroming } \\
\text { voorlanden en } \\
\text { buitenwaarden }\end{array}$ & $\begin{array}{l}\text { - } \quad \text { Palenrijen, vooroevers en } \\
\text { zandmotoren } \\
\text { - } \quad \text { Luwte maatregelen ter bevordering } \\
\text { van rietoevers. Eventueel in } \\
\text { combinatie met een harde rand. } \\
\text { Risicospreiding / koppelen } \\
\text { natuurgebieden: zorg dat bij } \\
\text { extreme events altijd een } \\
\text { natuurgebied onaangetast blijft. } \\
\text { Het systeem op grotere tijd- en } \\
\text { ruimteschaal benaderen. }\end{array}$ & $\begin{array}{l}\text { Overstroming van de buitenwaarden is } \\
\text { alleen te voorkomen door de zomerdijk } \\
\text { naar de buitenwaarden te verhogen. De } \\
\text { erosieve effecten van de storm en de } \\
\text { opzet van water zijn te mitigeren door } \\
\text { palenrijen, zandmotoren en vooroevers. } \\
\text { Effectiviteit van maatregelen is } \\
\text { afhankelijk van de locatie. Palenrijen } \\
\text { langs de Makkumer en Workumer } \\
\text { buitenwaarden kunnen effectief zijn, daar } \\
\text { waar geen recreatie plaatsvindt. } \\
\text { Rietkragen kunnen effectief zijn in de wat } \\
\text { meer beschutte delen van de } \\
\text { buitenwaarden (bijvoorbeeld langs de } \\
\text { kanalen tussen de Makkumerwaarden). } \\
\text { Zandmotoren kunnen een golf } \\
\text { verminderend effect hebben, maar extra } \\
\text { zandinbreng is niet overal wenselijk (zie } \\
\text { eerdere opmerkingen hierover) }\end{array}$ \\
\hline $\begin{array}{l}\text { Baggerbezwaar } \\
\text { vaargeulen }\end{array}$ & $\begin{array}{l}\text { Slim baggeren is een oplossing om het } \\
\text { zandtransport langs de westkust deels } \\
\text { in stand te houden. Bijvoorbeeld door } \\
\text { zand uit de vaargeulen noordwaarts } \\
\text { van de vaargeul aan te leggen. }\end{array}$ & $\begin{array}{l}\text { De Workumerbuitenwaard zandmotor is } \\
\text { deels aangelegd met gebaggerd } \\
\text { materiaal uit de Workumer vaargeul. }\end{array}$ \\
\hline
\end{tabular}




\section{Inleiding}

\section{$1.1 \quad$ Inleiding}

In de periode $2011 \mathrm{t} / \mathrm{m} 2016$ zijn er op twee locaties voor de Friese IJsselmeerkust experimenten uitgevoerd met zandmotoren. Deze pilots bij Workum en Oudemirdum zijn uitgevoerd in het kader van het Bulding with Nature programma en zijn bedoeld om kennis op te doen over het systeem en de effectiviteit van ecodynamische maatregelen voor het versterken van de Friese IJsselmeerkust. Hiervoor is een monitoringsprogramma opgezet dat loopt van 2011 tot en met 2017.

De kennis die in dit project wordt opgedaan vormt een belangrijke bouwsteen voor het ontwikkelen van een strategie voor duurzame kustbescherming en het versterken van de ecologische kwaliteit van de hele Friese IJsselmeerkust. De monitoring is gericht op het begrijpen van het gedrag van de zandmotoren, de effecten op de kust en de ecologie. Het monitoringsprogramma heeft als doel de volgende vragen te beantwoorden:

- Hoe verspreidt het zand zich en hoe snel bewegt het zand?

- Welke weersomstandigheden domineren veranderingen?

- Wat is het effect van de zandmotor op de kust?

- Wat zijn de effecten van de zandmotor op de ecologie zowel boven als onder water?

Dit rapport beschrijt de resultaten van de monitoring voor de periode $2011 \mathrm{t} / \mathrm{m} \mathrm{2015}$. De monitoring loopt door tot en met 2017, dit rapport is dan ook te beschouwen als een tussenstand. Omdat er in 2016 een MIRT-pre-verkenning start met als doel het vaststellen van compenserende maatregelen langs de Friese IJsselmeerkust voor het veranderende peilregime van het IJsselmeer is het opportuun om nu met deze tussenstand van monitoringsresultaten te komen. In 2017 worden de definitieve resultaten gepubliceerd.

\subsection{Opgaven Friese IJsselmeerkust}

In het IJsselmeergebied zullen de gevolgen van klimaatverandering zichtbaar en merkbaar worden. De zeespiegel stijgt en de afvoer van grote hoeveelheden rivierwater neemt toe, evenals de kans op droge zomers en perioden met overvloedige regenval. Dit brengt nieuwe uitdagingen met zich mee voor het waterpeilbeheer in het grootste zoetwatergebied van Nederland, het IJsselmeer. In het Deltaprogramma IJsselmeergebied is een voorkeursstrategie ontwikkeld voor het op orde houden van de waterafvoer van het IJsselmeer richting Waddenzee, bij stijgende zeespiegel, het versterken van de zoetwatervoorziening en het zo effectief mogelijk garanderen van de waterveiligheid.

In de Deltabeslissingen van 2014 is afgesproken dat vaste peilen van het IJsselmeer worden vervangen door flexibel peilbeheer. Dit ten behoeve van de zoetwatervoorraad. Hierbij is het uitgangspunt dat het gemiddelde winterpeil in het IJsselmeer onveranderd blijft tot 2050 en dat in het zomerseizoen de zoetwatervoorraad wordt vergroot (Deltaprogramma, 2014; NWP 2016-2021). De eerste stap naar flexibel peilbeheer wordt gezet vanaf 2020; na 2050 wordt rekening gehouden met vervolgstappen. De maatregelen hiervoor in het hoofdwatersysteem worden uitgevoerd in samenhang met maatregelen in het regionale watersysteem en met eindgebruikers. 

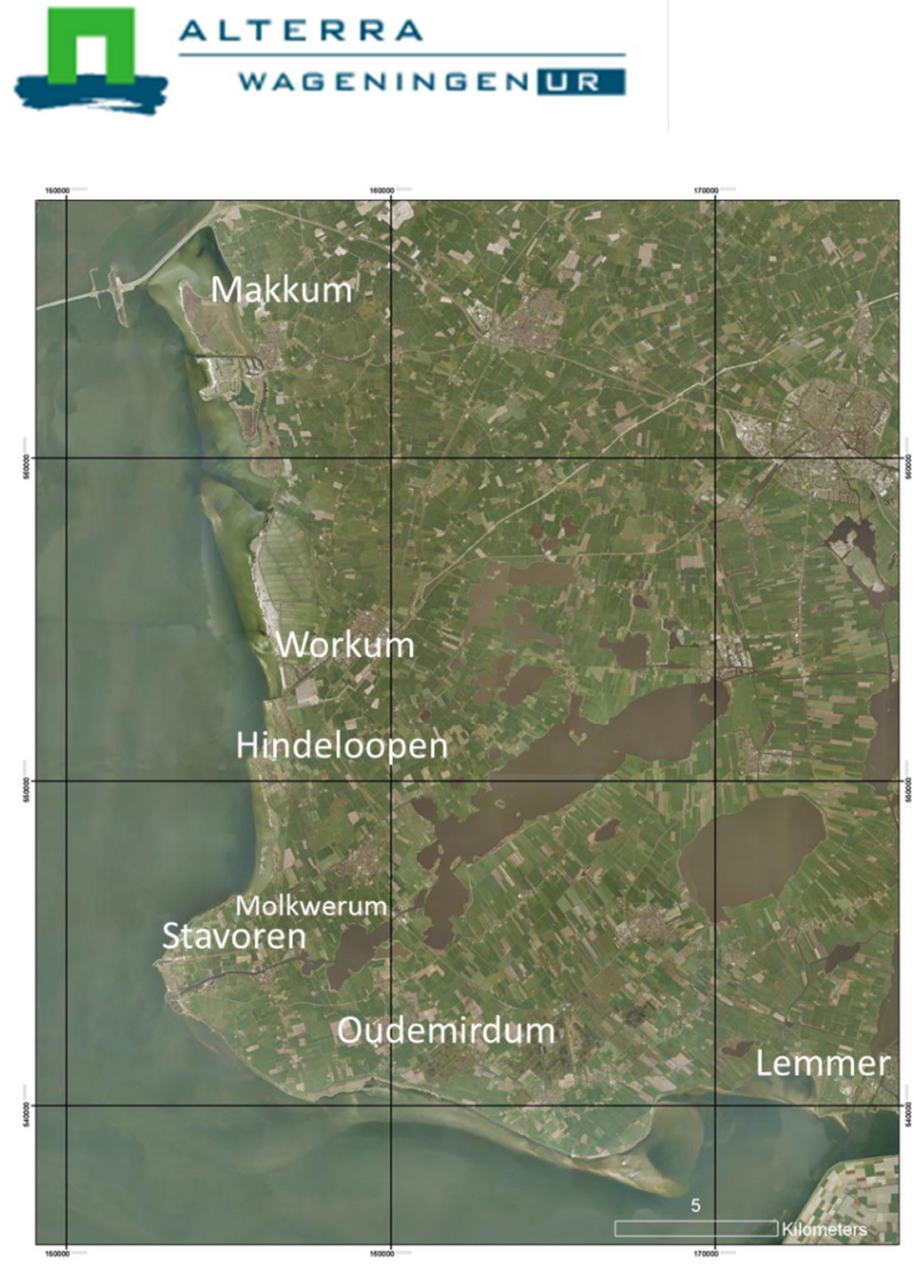

Figuur 1.1 Friese IJsselmeerkust en plaatsnamen.

Dit nieuwe peilbeheer heeft consequenties voor de waardevolle buitendijkse gebieden langs de Friese IJsselmeerkust (Figuur 1.1) en de waterveiligheid van het gebied daarachter. De buitendijkse gebieden zijn in de huidige situatie kwetsbaar voor erosie en komen bij storm onder water te staan. De buitendijkse gebieden langs de Friese IJsselmeerkust kennen een dynamisch evenwicht van erosie en sedimentatie (Menke \& Lenselink, 1998). Tien centimeter peilstijging betekent dat ruim honderd hectare land onder water komt te staan. Zonder aanvullende maatregelen zullen grote delen van de buitendijkse gebieden door erosie verdwijnen. Deze gebieden vertegenwoordigen belangrijke waarden voor natuur, recreatie en waterveiligheid. Daarom ontwikkelen betrokken partijen langs de Friese IJsselmeerkust - als nadere uitwerking van de Deltabeslissingen - een adaptatiestrategie voor een duurzame kustbescherming. De opgave is om de Friese IJsselmeerkust dermate veerkrachtig te maken, dat het de negatieve gevolgen van het verhoogde waterpeil op kan vangen. Ook als het waterpeil na 2050 verder omhoog gaat.

De Friese IJsselmeerkust heeft nu al een waterveiligheidsopgave. Tijdens de derde toetsronde Primaire Waterkeringen is een aantal dijktrajecten afgekeurd en andere trajecten hebben geen oordeel (Figuur 1.2). Het feit dat deze trajecten moeten worden versterkt biedt kansen om waterveiligheids- en ecodynamische oplossingen te combineren. De uitdaging bij de waterveiligheidsopgave is om deze sober en doelmatig op te lossen ("http://www.hoogwaterbeschermingsprogramma.nl"). Maar ook slimme combinaties, waarbij veiligheid en natuur (en andere waarden) worden vergroot, zijn mogelijk.

De Friese IJsselmeerkust valt onder de Habitatrichtlijn en is onderdeel van het N2000 gebied IJsselmeer. Het Habitatrichtlijngebied bestaat uit brede, ondiepe oeverzones (max. 2 meter diep), kale en begroeide zandplaten/schelpenbanken, moerassen en graslanden (waarden), klifkusten en ondiepe wateren op de zandplaten. De aangewezen habitattypen zijn 
kranswiervegetaties (H3140) en ruigten en zomen (H6430). De belangrijkste knelpunten voor deze habitattypen zijn: waterregime (het huidige omgekeerd peilbeheer), trofiegraad oppervlaktewater, optredende verzoeting, en beheer. De ontwikkeling en het perspectief van habitattypen voor komende decennia moet nader worden uitgewerkt in samenhang met de ontwikkelingen in het IJsselmeer (www.synbiosys.alterra.nl).

In het Deltafonds is 12 miljoen euro gereserveerd voor natuurmaatregelen om de nadelige effecten van het nieuwe peilbeheer te mitigeren. Rijk (ministerie I\&M) en regio (provincie Friesland) werken nu via een pré-verkenning (MIRT) samen aan een maatregelenpakket waarbij naast natuurdoelen ook andere doelen worden gerealiseerd. Er wordt vanuit de provincie gericht gezocht naar meekoppelkansen, om wensen en doelen vanuit recreatie, waterveiligheid, visserij en natuur te combineren.

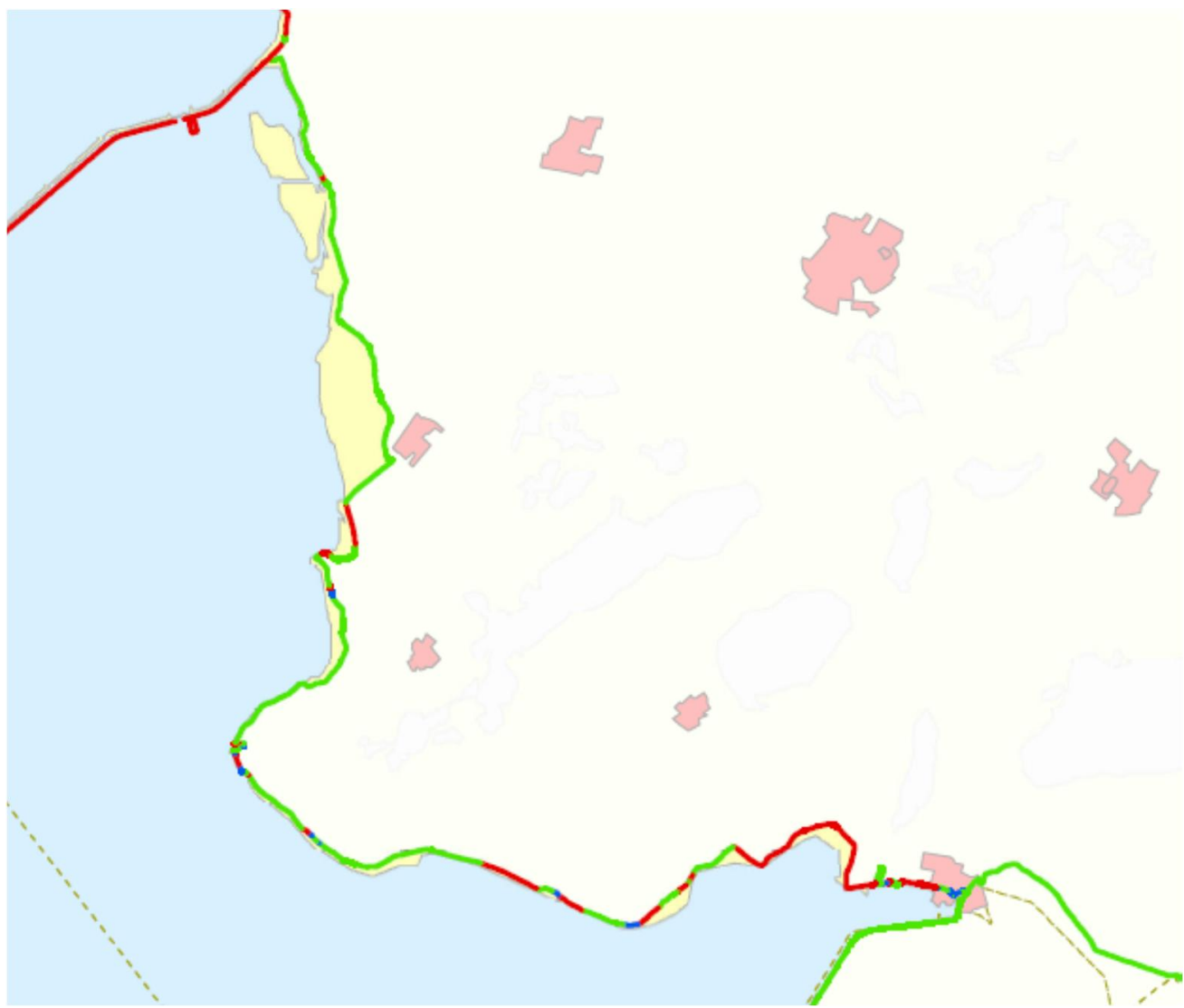

Figuur 1.2 Resultaten van de Derde Toetsing (2006-2011) Groen: waterkering voldoet aan de norm en is goedgekeurd, blauw: waterkering is niet beoordeeld, rood: waterkering voldoet niet aan de norm en is afgekeurd. De lichtgele gebieden geven de buitendijkse gebieden weer.

\subsection{Building with Nature als mogelijke oplossing}

Als reactie op het Advies van de Commissie Veerman (Deltacommissie, 2008) waarin een peilverhoging op het IJsselmeer werd voorgesteld besloot een consortium van Friese partijen (waterschap, gemeenten, provincie, Rijkswaterstaat, natuurorganisatie It Fryske Gea) en Ecoshape (consortium van baggeraars, adviesbureaus, overheden en kennisinstellingen) in 2010 om experimenten uit te voeren volgens de principes van Building with Nature (zie Hoofdstuk 3.). Dat principe behelst dat zo goed mogelijk gebruik gemaakt wordt van natuurlijke factoren zoals wind, water en golven, sediment en zandtransport, en vegetatie om 


\section{WLEENINGEN UR}

op duurzame wijze ecosysteemdiensten te leveren. Bij de Friese IJsselmeerkust gaat het bijvoorbeeld om het bijdragen aan functies en ambities voor natuur, waterveiligheid, zoetwaterbeschikbaarheid, visserij, recreatie en infrastructuur. Kustbescherming, waarbij de huidige buitendijkse gebieden, ondieptes, platen en banken in stand blijven, staat centraal.

Bij de kust van de Workumerwaard, Oudemirdum en Hindeloopen onderzoekt Ecoshapebinnen het project 'De Zachte Zandmotor' verschillende 'zandige' maatregelen om de vooroever mee te laten groeien met een eventuele peilverhoging. De hypothese waarop de ontwerpen gestoeld zijn luidt:

De zandmotor is een effectieve Building with Nature maatregel die de oever ter plaatse bij een veranderend peilbeheer behoudt en de ecologische kwaliteit en/of de veiligheid van de kust verhoogt.

\subsection{Pilots zandmotor Friese IJsselmeerkust}

Het project is met drie pilotstudies uitgevoerd, twee veldexperimenten en een modeluitwerking. Op twee plaatsen langs de Friese IJsselmeerkust zijn zandsuppleties aangelegd. Het accent van de pilot Workum ligt op waterveiligheid in combinatie met natuurontwikkeling, het accent van de pilot Oudemirdum op versterken van de veiligheid. Voor de derde locatie bij Hindeloopen is een modelstudie uitgevoerd, het accent daar ligt op waterveiligheid en recreatie.

Om bovenstaande hypothese te testen zijn op twee locaties pilots uitgevoerd met de zandmotor en is een uitgebreid monitoringsprogramma opgezet dat in de periode $2011 \mathrm{t} / \mathrm{m}$ 2017 de effecten van de zandmotoren op de kust volgt en monitort hoe het zand zich beweegt en welke effecten er zijn op de vegetatie onder water en boven water. De pilots zijn bedoeld om kennis op te doen van het systeem en de effectiviteit van het concept zandmotor in een meer. Dit project moet antwoord geven op de volgende hoofdvragen:

- Is de zandmotor een effectieve, duurzame en ecologisch robuuste maatregel voor het versterken van de Friese IJsselmeerkust?

- Verhoogt het de ecologische kwaliteit

- Verhoogt het de veiligheid

- Onder welke voorwaarden kan het concept de zandmotor worden opgeschaald naar andere locaties langs de Friese IJsselmeerkust?

Dit rapport beschrijft de experimenten en trekt, op grond van de monitoring resultaten lessen over natuurlijke processen, over de effectiviteit van het concept zandmotor in het IJsselmeer en over de mogelijkheid om deze experimenten op te schalen. Bijvoorbeeld over grotere delen van de Friese IJsselmeerkust, of naar andere delta meren in de wereld. Ook doet het rapport aanbevelingen om te komen tot een ecodynamische en toekomstbestendige kustbescherming van de Friese IJsselmeerkust.

\subsection{Doel}

Het project de Zachte Zandmotor langs de Friese IJsselmeerkust heeft als doel om kennis te ontwikkelen over of en hoe de aanleg van een zandmotor kan leiden tot een duurzamer, goedkoper en ecologisch robuustere wijze van kustbescherming. Hierbij wordt uitgegaan van de inzet van natuurlijke processen bij de verdediging van de kust in relatie tot toekomstige peilstijging en peilfluctuaties. Door de aanzanding langs de Friese kust te stimuleren, ontstaan bredere, oplopende vooroevers die de kwetsbaarheid van de buitendijkse natuurgebieden voor overstroming verminderen. Deze is als golfremmer eveneens een 
integraal deel van de toekomstige kustversterking. Met de ontwikkelde kennis willen de Ecoshape partners de effectiviteit en de voordelen van een zandmotor in een meer beter onderbouwen zodat een bredere toepassing van het concept mogelijk wordt. Tevens zullen deze pilots bijdragen aan het vergroten van het draagvlak voor ecodynamische kustbescherming.

\subsection{Leeswijzer}

Hoofdstuk 2 geeft een systeembeschrijving van de Friese IJsselmeerkust. In Hoofdstuk 3 van het rapport wordt uitgelegd wat we verstaan onder Building with Nature. Hoofdstuk 4 beschrijft hoe het concept van de zandmotor in de Building with Nature pilots voor de Friese IJsselmeerkust is toegepast. Hierin wordt ook de modelstudie bij Hindeloopen besproken. In hoofdstuk 5 worden de resultaten van het monitoringsprogramma in de periode $2010 \mathrm{t} / \mathrm{m}$ 2015 beschreven. In hoofdstuk 6 worden de monitoringsresultaten bediscussieerd in de vorm van "lessons learned" en ontwerprichtlijnen, en hoe deze kunnen worden opgeschaald voor het toekomstbestendig maken van de gehele Friese IJsselmeerkust. 


\section{Systeembeschrijving Friese IJsselmeerkust}

\subsection{Morfologische ontwikkeling van de Friese IJsselmeerkust}

De Friese IJsselmeerkust wordt gekenmerkt door grote buitendijkse gebieden, uitgestrekte ondiepten en zelfs steile kliffen. Deze morfologie van de kust is grotendeels een overblijfsel van de Zuiderzeekust zoals die bestond voor de voltooiing van de afsluitdijk in 1932 (Figuur 2.1). Met deze afsluiting veranderde de zoute zee met getij in een zoetwatermeer. Ook werd in 1945 een vast winterpeil van $40 \mathrm{~cm}$-NAP en een zomerpeil van $20 \mathrm{~cm}$-NAP ingevoerd. Hierdoor vielen de voormalige getijdeplaten en kwelders permanent droog en raakten begroeid. De platen onder water vormden uitgestrekte ondiepten voor kust (Figuur 2.2).

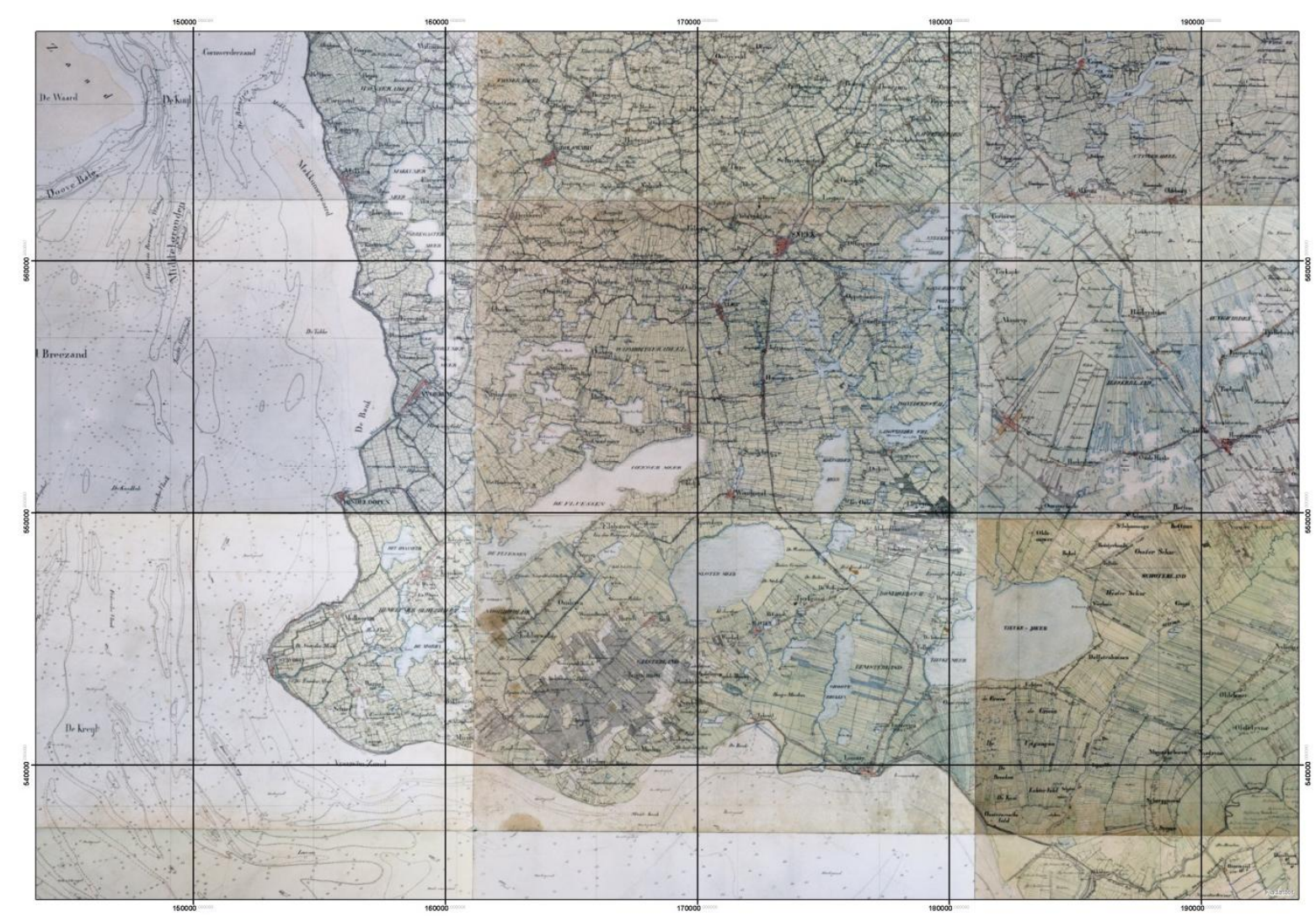

Figuur 2.1 De Friese Zuiderzeekust op militaire kaarten uit 1845. De dijk loopt op exact dezelfde plek en buitendijks zijn ondiepe gebieden. De morfologie van de kust is vrijwel hetzelfde, en de getijdeplaten en kwelders zijn begroeid of vormen uitgestrekte ondiepten.

Door het vaste peil en gebrek aan getijdendynamiek is er geen sedimentaanvoer meer naar de buitendijkse gebieden tijdens vloed, en concentreert de golfaanval zich op één niveau. Hierdoor treedt erosie op van de kust, en verdwijnt zand uit het systeem. Ondanks deze "zandhonger", blijkt uit een luchtfotoanalyse dat over de termijn van 1945 tot 1989 de Friese IJsselmeerkust als geheel in een dynamisch evenwicht verkeert (Menke en Lenselink, 1998). Met andere woorden: op sommige plekken erodeert de kust, op andere plaatsen vindt uitbreiding van het buitendijkse landareaal plaats. Deze uitbreiding bestaat bijvoorbeeld uit dichtgeslibde kreken of uitbreiding van rietvlakten. Over de Workumerwaard schrijven Menke 
en Lenselink (1998) dat het opvallend is dat hier al sinds 1945 erosie optreedt, en ze wijten dit aan de verandering in landgebruik van riet naar grasland.

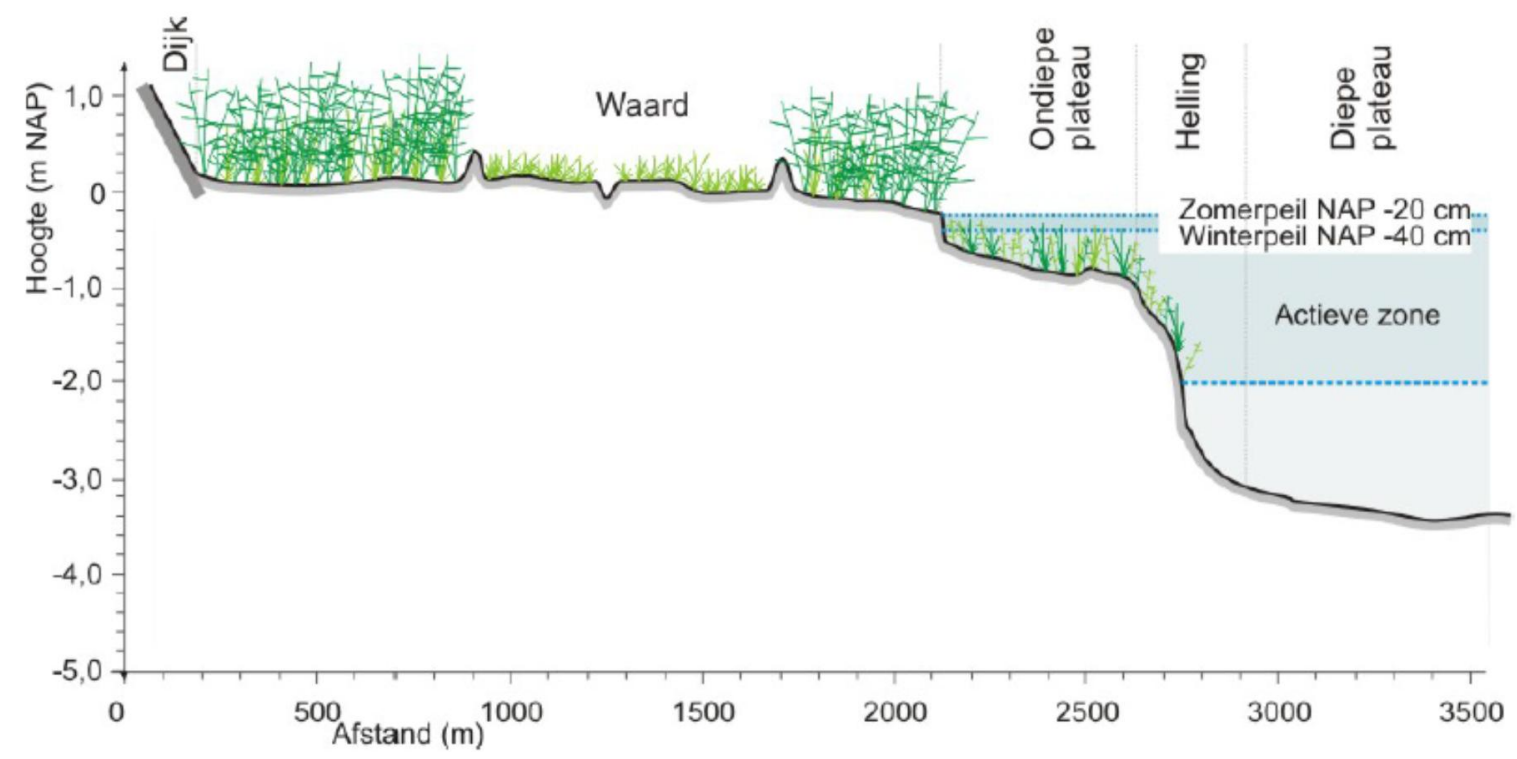

Figuur 2.2 Schematische dwarsdoorsnede van de Friese kust van Kornwerderzand tot Molkwerum (Uit: Folmer et al., 2010).

Sedimenttransport langs de Friese IJsselmeerkust vindt plaats door stroming veroorzaakt door golven of wind (Folmer et al, 2010). Golven ontstaan door de overheersende wind vanuit het westen of zuidwesten op het IJsselmeer. Als de golfbasis de ondiepere gebieden langs de Friese kust raken wordt sediment losgewoeld van de bodem en door de stroming die samenhangt met de golf getransporteerd. De diepte tot waar golven sediment opwoelen en transporteren is tot ongeveer $2 \mathrm{~m}$ diepte (Folmer et al., 2010; Jansen, 2014). Het sedimenttransport heeft een kustlangs- en kustdwarscomponent. Figuur 2.3 geeft de grootte van het gemiddelde jaarlijkse sedimenttransport langs de Friese IJsselmeerkust aan (Folmer et al., 2010) berekend door middel van het CROSMOR rekenmodel (Van Rijn, 2006). Hierin is het gemiddelde jaarlijkse kustlangstransport 1.000 m3/jaar. Menke en Lenselink (1998) berekenen met het UNIBEST model langstransporten tot maximaal $25.000 \mathrm{~m} 3 / \mathrm{jaar}$.

Volgens dit model vindt het meeste sedimenttransport plaats op dieptes tussen de 1 en $2 \mathrm{~m}-$ NAP. Tussen Stavoren en Makkum is het overheersende sedimenttransport noordwaarts gericht; tussen Stavoren en Lemmer is het transport oostwaarts gericht. De transporten langs de kust zijn beduidend groter dan de transporten dwars op de kust. Eén van de conclusies van het modelonderzoek van Folmer et al. (2010) is dat bij hogere waterstanden (harde (zuid)westenwind) het sedimenttransport verschuift naar ondieper water. Bij die omstandigheden overheerst sedimenttransport richting kust. Omdat die storm omstandigheden niet vaak voorkomen, heeft sedimenttansport richting het IJsselmeer over het jaar gemiddeld op de meeste plaatsen de overhand (Folmer et al., 2010). 


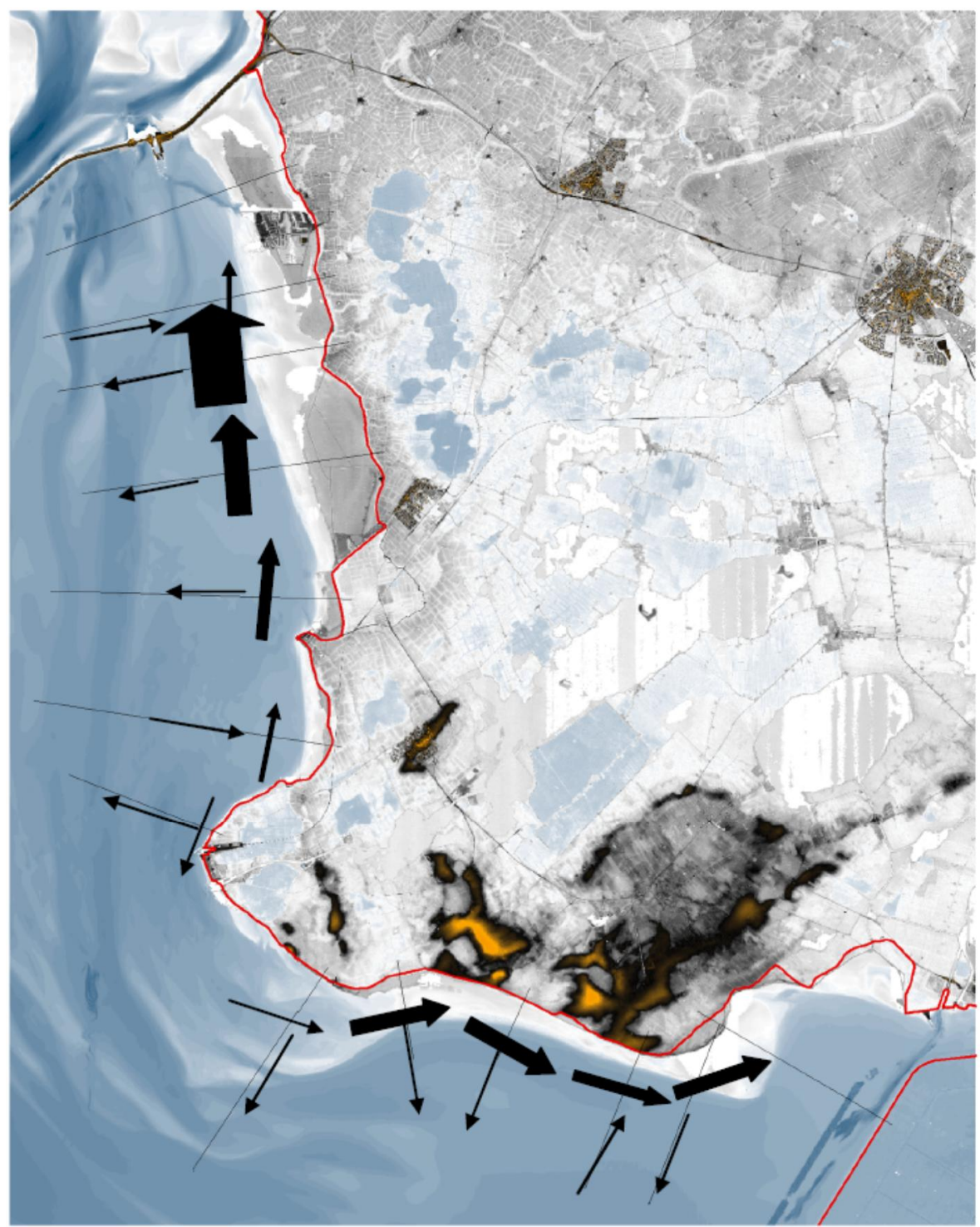

Figuur 2.3 Jaarlijks gemiddelde kustlangs- en kustdwarssedimenttransport langs de Friese IJsselmeerkust, berekend voor elf dwarsdoorsneden onder realistisch golfklimaat en waterstanden met het rekenmodel CROSMOR. Figuur afkomstig uit Folmer (2010). De dikste pijl is staat voor 1.000m3/jaar.

De rand van de ondiepte tussen de -2 en -1 m NAP waar de golven breken en waarin volgens deze modellen het zandtransport plaatsvindt wordt gekenmerkt door kustparallelle zandruggen van enkele tientallen meters breed. De zandruggen vertonen dynamiek en veranderen door de jaren heen, en mogelijk door de seizoenen heen, geleidelijk in positie en hoogte.

Op grotere schaal vertonen de ondiepe gebieden langs de Friese IJsselmeerkust ook dynamiek. Luchtfoto's ten noorden van het havenkanaal bij Workum laten dat het talud van het ondiepe naar het diepe gedeelte ongeveer 100 m landwaarts is gegaan tussen 1996 en 2013 (Figuur 2.4). Daarentegen is het talud ten noorden hiervan langs de Workumerwaard tientallen meters meerwaarts uitgebreid. Deze observatie kan het gevolg zijn van de weerscondities en waterpeil ten tijde van het nemen van de luchtfoto, waardoor bijvoorbeeld de zandruggen onder water meer of minder zichtbaar waren. Echter, gezien het feit dat in het 


\section{$-\frac{A L T E R R A}{\text { WAGENINGENUR }}$}

zuidelijk deel afslag en in het noordelijke deel een uitbouw is te zien (dus een tegengestelde trend in één luchtfoto), lijkt het om een betrouwbare waarneming te gaan. Bovendien is deze trend zichtbaar op een serie luchtfoto's van 1996 tot 2013.

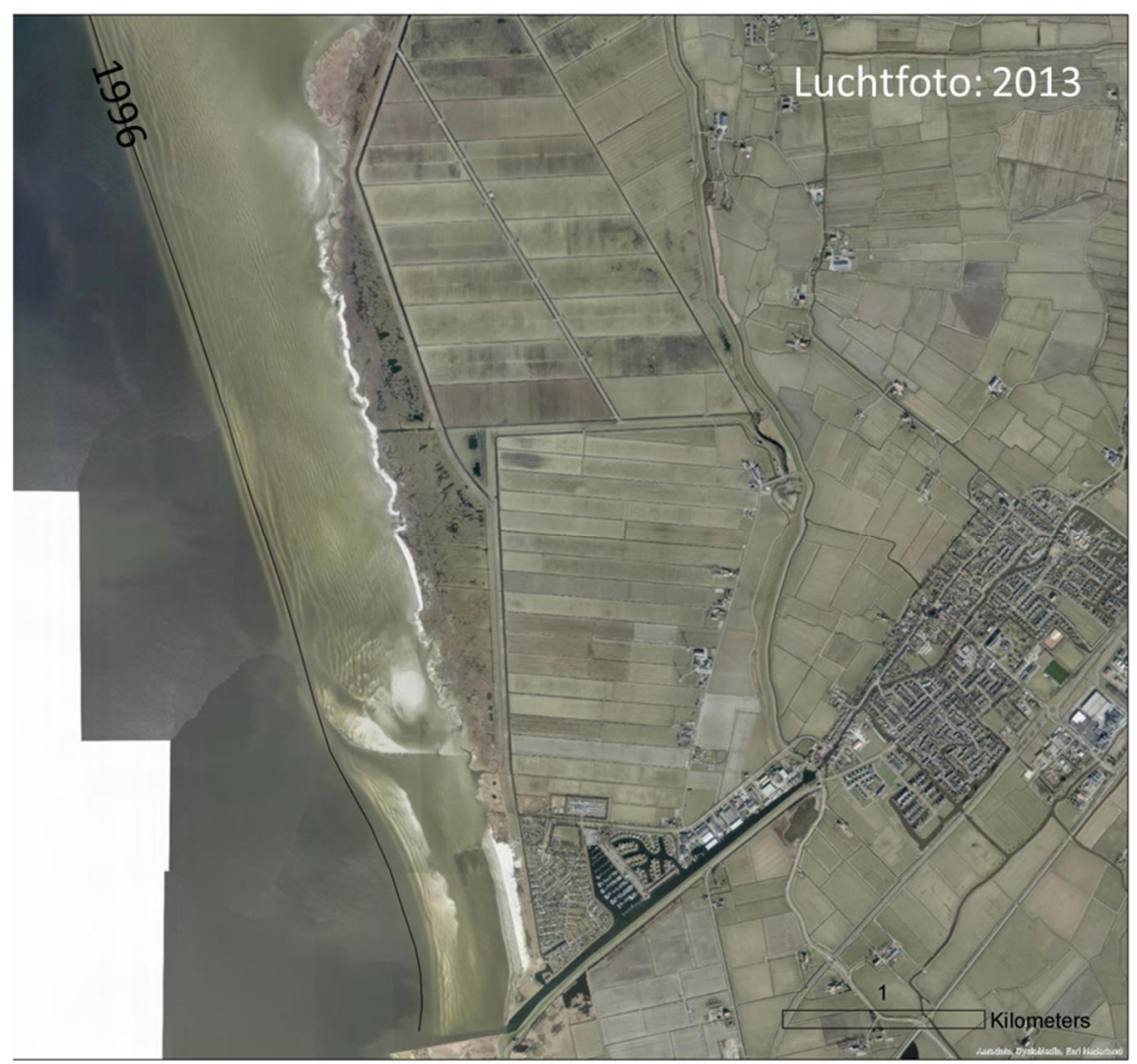

Figuur 2.4 Luchtfoto uit 2013 van de IJsselmeerkust voor Workum (Bron: LuchtfotoNL $50 \mathrm{~cm}$ (2013) - Aerodata, CycloMedia, Esri Nederland). De zwarte lijn geeft de ligging aan van de rand van de ondiepte volgens luchtfoto's uit 1996.

De verschuiving van de positie van het talud heeft waarschijnlijk te maken met de aanleg van de haakvormige dam en mogelijk met de aanleg van de dam ten zuiden van de vaargeul. Door de dam in het zuiden en de vaargeul wordt er geen zand aangevoerd vanuit het zuiden, en door de haakdam in het noorden wordt het mogelijk versneld afgevoerd naar het noorden. Het gebied met het strand lijkt ook te verondiepen. Dit wordt bevestigd door lokale observaties.

Het noordwaartse sedimenttransport langs de westkust en oostwaartse sedimenttransport langs de zuidkust kan gezien worden als een lopende band van zand (Figuur 2.5bij de start wordt sediment weggehaald en aan het eind wordt zand afgezet.

- Langs de Zuidelijke kust is de bron van het zand het ondiepe Vrouwenzand ten zuidwesten van Stavoren. Veel zand verzamelt zich op de Steile Bank ten zuidoosten van Oudemirdum. Deze ondiepte bestaat uit banken, die migreren. De zuidkust is niet onderbroken door vaargeulen en kan worden gezien als één systeem. 
- Het zuidelijke deel van de westkust bij Stavoren is vrij steil waardoor er geen uitgestrekte ondiepten bestaan. Hierdoor vindt er nauwelijks zandtransport plaats. Transport van significante hoeveelheden zand naar het noorden start in de ondiepte tussen Molkwerum en Hindeloopen. Vanaf daar richting het noorden zijn enkele deelsystemen herkenbaar waarin zandtransport van zuid naar noord plaats vindt. Deze deelsystemen zijn:

1. Van Molkwerum tot de havenvaargeul bij Hindelopen

2. Van de havenvaargeul bij Hindeloopen tot de havenvaargeul bij Workum

3. Van de havenvaargeul van Workum tot een natuurlijke verdieping bij Gaast

4. Van Gaast tot de havenvaargeul bij Makkum

5. Van de havenvaargeul bij Makkum tot de Afsluitdijk

Sub-gebieden 3 en 4 zijn mogelijk één gebied, omdat mogelijk wel sedimentuitwisseling plaatsvindt langs de natuurlijke ondiepte. In het zuiden van ieder van deze sub-gebieden zal zand verdwijnen en aan de noordkant zal sedimentatie optreden. Deze sedimentatie wordt waargenomen als toegenomen baggerbezwaar in de havenvaargeulen. Bij de afwezigheid van de vaargeulen zou het systeem langs de westkust minder gecompartimenteerd zijn en zou zich zand van Molkwerum naar Makkum verplaatsen. Bij het zoeken naar oplossingen voor de versterking van de IJsselmeerkust met ecodynamische maatregelen moet met deze compartimentering rekening worden gehouden.

Op korte tijdschalen kan het sedimenttransport ook in tegengestelde richting gaan. Een voorbeeld is het verzanden van de vaargeul naar Workum tijdens harde noordwester- of noorderwind. Bij deze omstandigheden wordt zand uit het ondiepe gebied voor strand It Soal getransporteerd en afgezet in de vaargeul. Eenmaal afgezet op diepte wordt het niet meer getransporteerd en hoopt het zich op. 

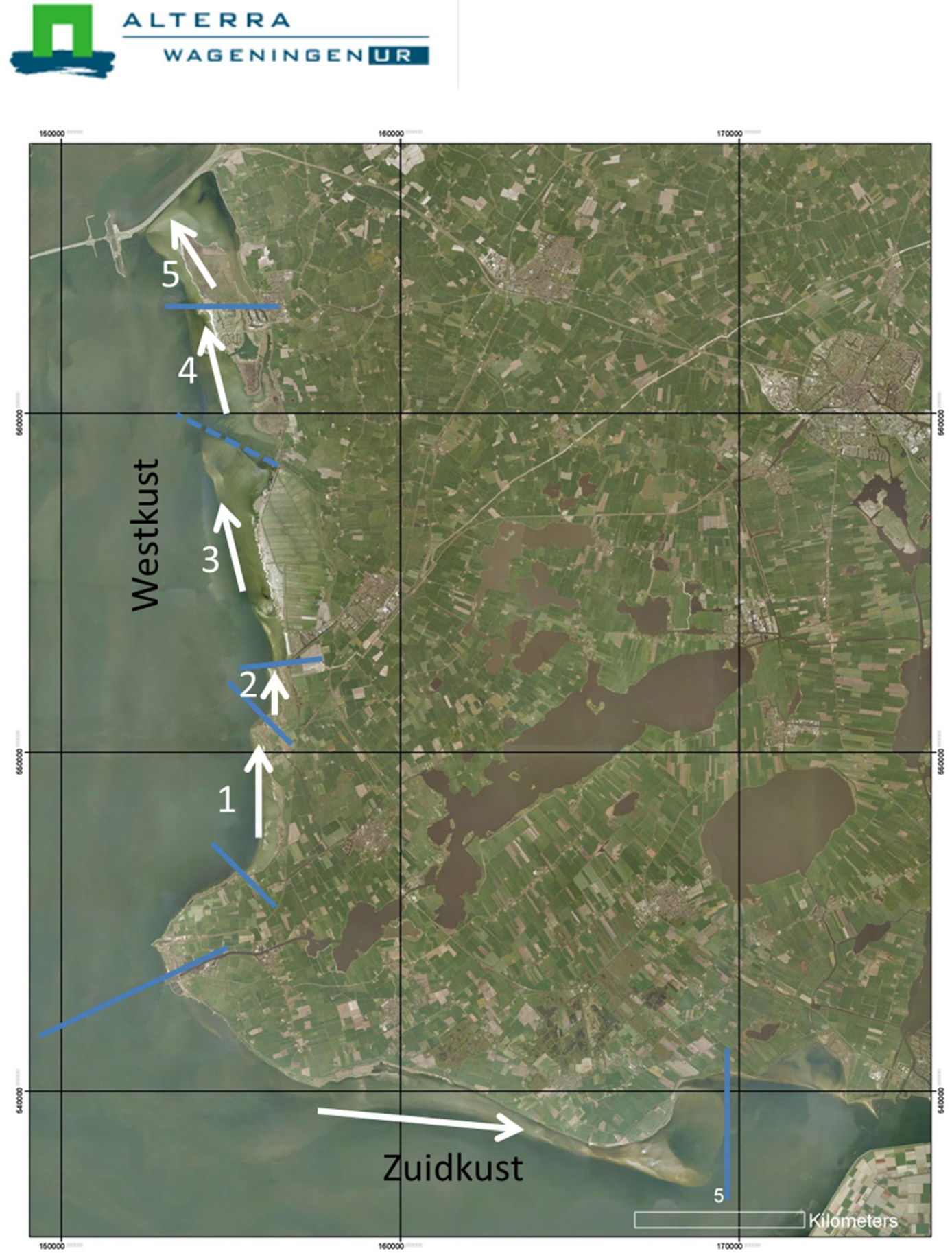

Figuur 2.5 Deelsystemen in het zandtransport langs de Friese IJsselmeerkust.

\subsection{Eerdere ingrepen}

Op de vooroever is de laatste decennia geëxperimenteerd met suppleties en eilanden. Deze zijn deels aangelegd om de kust te versterken (het stoppen van erosie van buitendijkse gebieden) en deels ter bevordering van de natuurontwikkeling van de kust. De resultaten van deze projecten zijn beschreven in Bak et al. (2007), Lauwaars en Platteeuw (1999) en Groot et al. (2012). De beschrijvingen van deze projecten in deze studie zijn samenvattingen uit deze rapportages. Voor een meer uitgebreide beschrijving van de projecten en de effecten wordt verwezen naar de originele rapporten. 


\section{Workumer buitenwaard}

Bij de Workumer buitenwaard is in 1992 een zandplaat van $2 \mathrm{~km}$ lengte en $150 \mathrm{~m}$ breedte (450.000 $\mathrm{m}^{3}$ zand) gesuppleerd, deels met de kruin boven water (Figuur 2.6). De locatie omvat de pilot zandmotor locatie aangelegd in 2011. Deze zandplaten waren bedoeld als habitat voor diverse vogelsoorten, bescherming van de kust tegen erosie en het stimuleren van aangroei van de kust door kustwaarts transport van zand. In de jaren na de aanleg is het gebied regelmatig, maar met lage frequentie gemonitord. Hieruit bleek dat de zandplaten al snel uitzakten en verspoelden en permanent onder water stonden. Er is nauwelijks zand naar de kust toe verplaatst, maar voornamelijk naar het noorden en naar het diepere deel van het IJsselmeer. Ondergedoken waterplanten profiteerden van de verondieping.

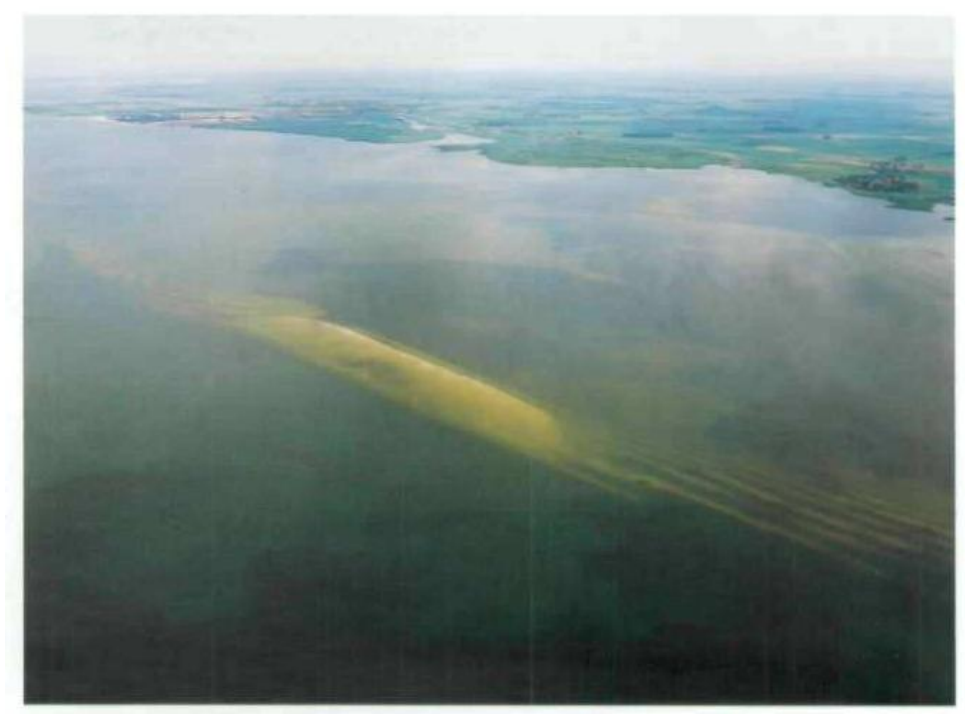

Figuur 2.6 Zandsuppletie uit 1992 bij de Workumerwaard (Uit: Lauwaars en Platteeuw, 1999)

\section{It Soal}

Bij It Soal nabij Workum zijn in de periode 1995 - 1997 twee eilandjes van $15.000 \mathrm{~m}^{3}$ zand met een oppervlakte van 0,6 ha op de ondiepe vooroever aangelegd (Figuur 2.7). Het doel was het versterken van de natuurontwikkeling. Deze worden beschermd door een $900 \mathrm{~m}$ lange stortstenen dam. Beide gebieden worden door vogels gebruikt als rust- en foerageergebied en deze gebieden worden door It Fryske Gea beheerd. Het idee leeft dat door de aanleg van eilandjes de waterkwaliteit achteruit gaat door verminderde doorstroming achter de eilandjes. 


\section{$\underbrace{}_{-3} \frac{\text { ALTERRA }}{\text { WAGENINGENUR }}$}

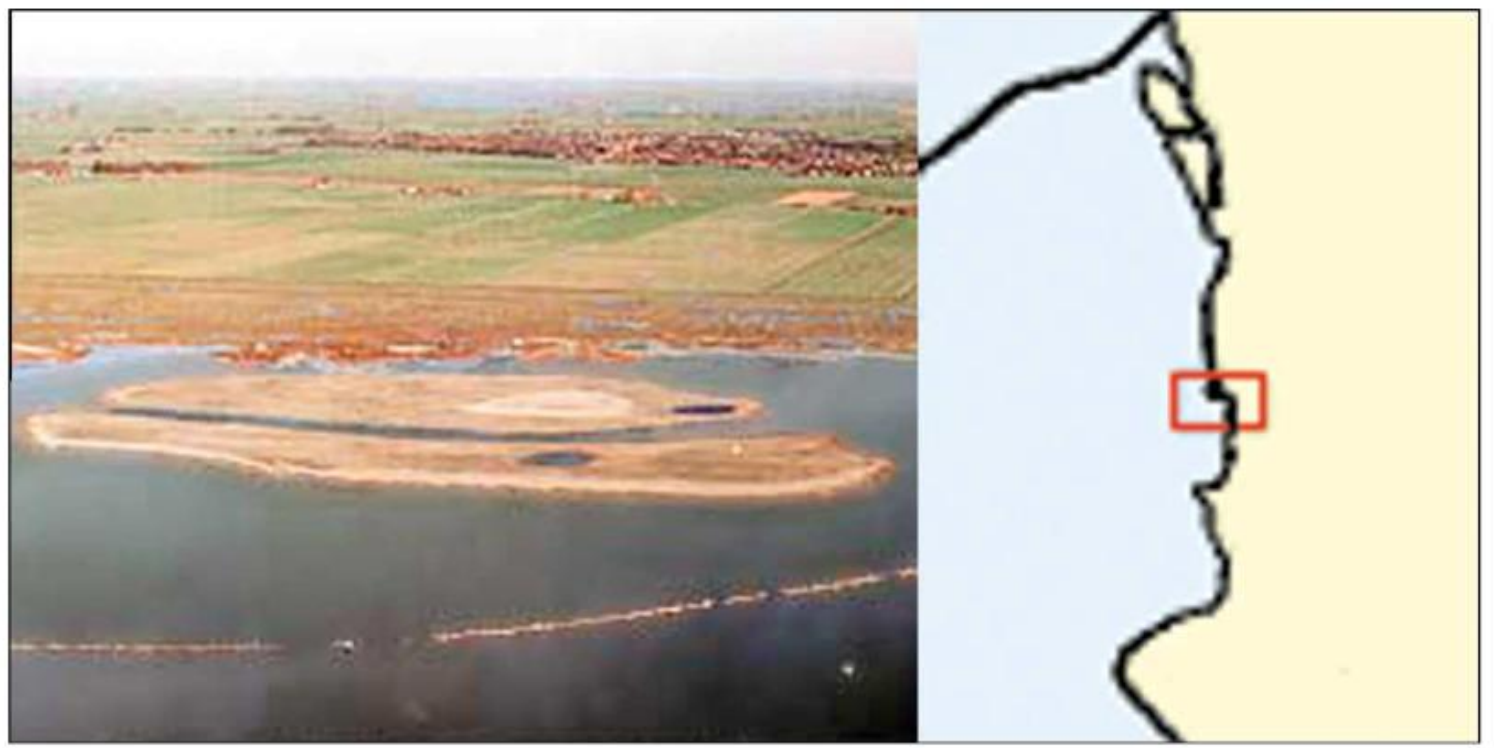

Figuur 2.7 Eilandjes bij It Soal achter de stortstenen dam.

\section{Bocht van Molkwerum}

In de bocht van Molkwerum zijn in 1994/1995 drie verdedigde eilandjes met een oppervlakte van in totaal 9 ha aangelegd (Figuur 2.8). Deze eilandjes zijn afgedekt met grind en door een stenen dam verdedigd. De eilandjes zijn onderling verbonden door een onderwaterdam. Het doel van de eilandjes was om een broedbiotoop voor kale grond broeders en een rustplaats voor watervogels te creëren. Achter de eilanden was een uitbreiding van moerasvegetatie voorzien, als broedbiotoop voor riet- en moerasvogels.

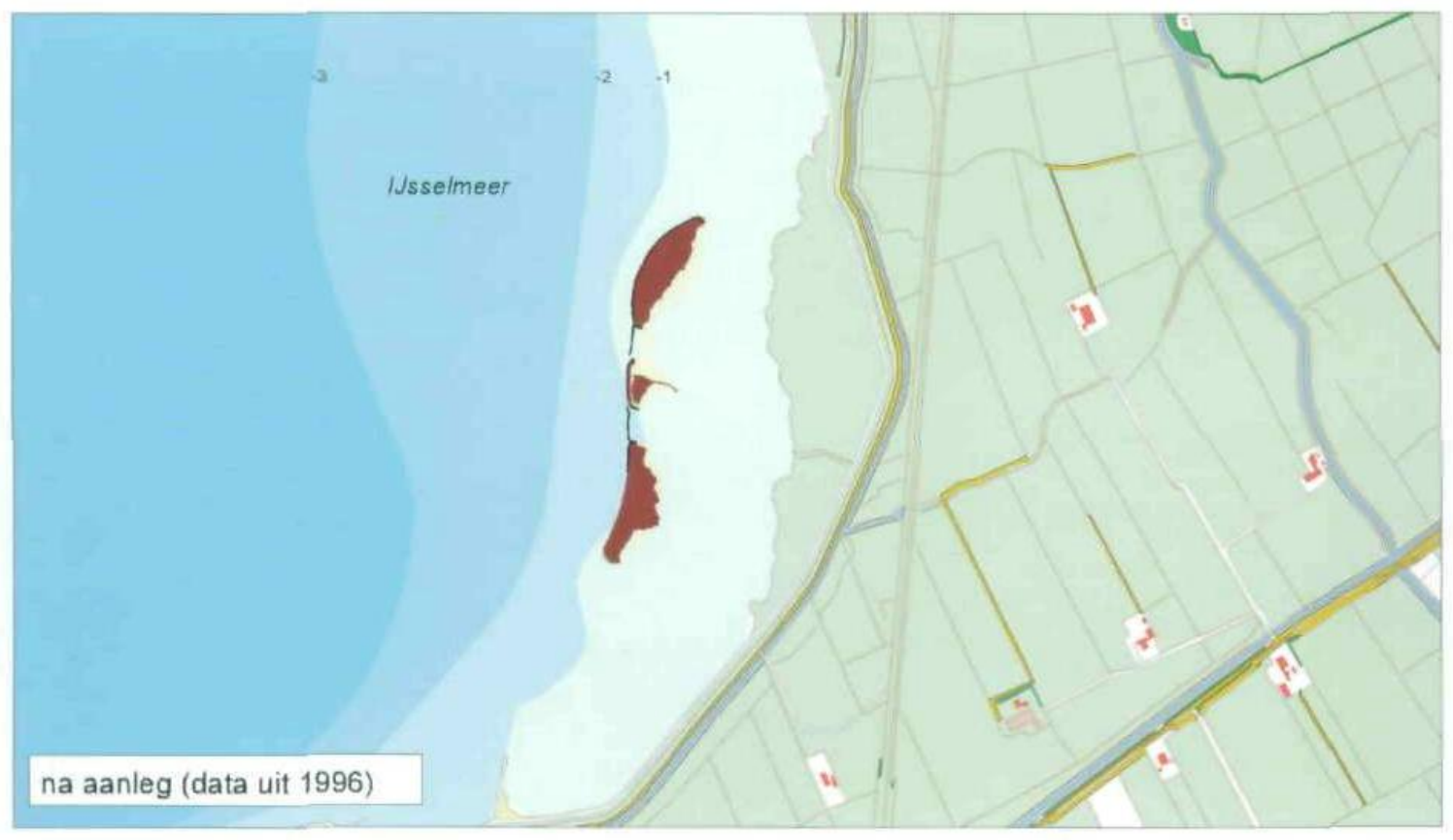

Figuur 2.8 Eilanden en versterkingen bij Molkwerum (Uit: Lauwaars en Platteeuw, 1999). 
De eilanden raakten snel begroeid met een soortenrijke vegetatie door het schrale karakter. De eilanden zijn goed behouden door de versterking. Achter de eilanden is een luwe ondiepte ontstaan.

\section{Mirnserklif}

In 1993/1994 zijn bij het Mirserklif nabij Natuurgebied de Mokkebank vier onverdedigde zandplaten aangelegd van in totaal $120.000 \mathrm{~m}^{3}$ (Figuur 2.9). De doelen waren het creëren van een fourageer-, broed- en rustbiotoop voor vogels en natuurlijke uitbreiding van de moerasvegetatie achter de eilandjes.

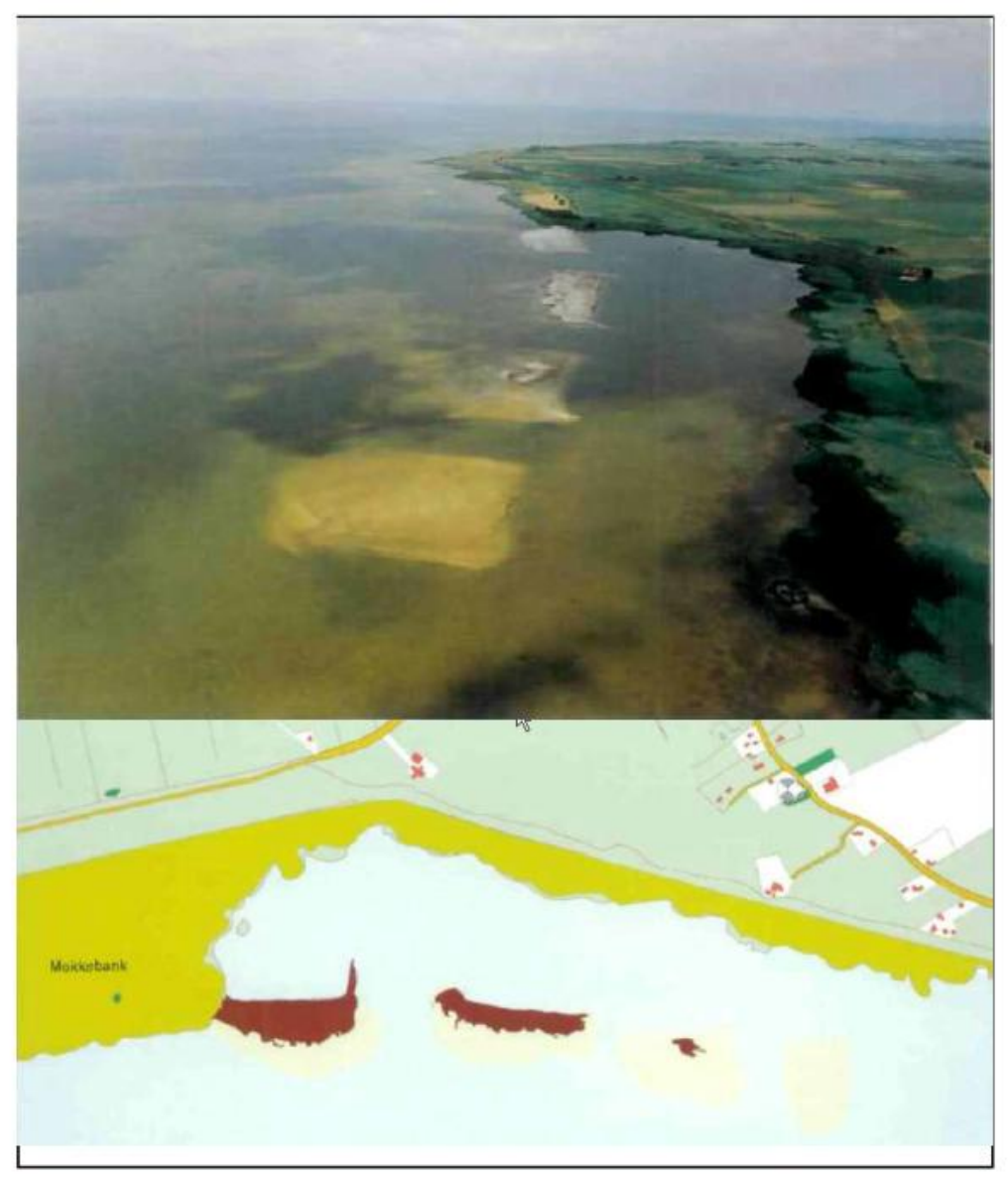

Figuur 2.9 Zandplaten bij Mirserklif in 1996, 2 jaar na aanleg (Bak et al., 2007 en Lauwaars en Platteeuw, 1999)

De zandplaten waren op verschillende hoogtes aangelegd. Zij verspoelden conform verwachting en groeiden naar elkaar toe. Het meest oostelijk gelegen zandplaat verdween in 2007 onder water. De twee meest westelijk gelegen eilandjes zijn vergroeid met de oever tot een schiereilandje aan de Mokkebank. Er is inmiddels nog één zandplaat over. Op het schiereiland heeft verruiging plaatsgevonden, en achter de (voormalige) eilandjes vindt verondieping plaats door verspoeling van sediment en de ontwikkeling van oever- en moerasvegetatie. 
ALTERRA

\subsection{Algemeen beeld van de aquatische vegetatie langs de Friese IJsselmeerkust}

De aquatische vegetatie langs de Friese IJsselmeerkust wordt door Rijkswaterstaat gemonitord. De RWS kartering (jaren 1995, 1998, 2001, 2005, 2008) van het gebied Kornwerderzand - Workum laat zien dat de meest voorkomende soorten Schedefonteinkruid, Gesteelde Zannichellia, Kranswier en Tenger fonteinkruid zijn. De dichtheden zijn laag, de totale bedekking aan waterplanten ligt tussen de 5 en $25 \%$, overeenkomend met MWTL klasse 2 - 4 (Koenjer et al., 2002). Uit de MWTL-verspreidingskaarten blijkt dat alleen in de zone langs de oever waterplanten voorkomen, tot ca. 500 meter uit de kust. Het bedekkingspercentage neemt af met toenemende afstand van de kust. In de zone vlak langs de oeverlijn is het bedekkingspercentage het hoogst, tot $50 \%$. In de zone tot $500 \mathrm{~m}$ uit de kust varieert het bedekkingspercentage tussen 1 en $15 \%$. Nog verder uit de kust worden op het ondiepe zandplateau slechts incidenteel waterplanten waargenomen. (Koenjer et al., 2002).

\subsection{Algemeen beeld terrestrische vegetatie Workumer buitenwaard}

De Workumerwaard is een voormalige kale zandplaat van de Zuiderzee. Na afsluiting van de Zuiderzee door de Afsluitdijk werd het peil in het IJsselmeer verlaagd. Daardoor vielen enkele zandplaten langs de Friese kust droog, waaronder die bij Workum (Slager, 1983). In de periode 1934-1940 is het zuidelijk deel omkaad, en in 1948 het noordelijk deel. Deze omkading verdeelt de waard in binnenwaard en buitenwaard. De Workumer binnenwaard is in cultuur gebracht en kent een landbouwkundig gebruik als grasland. De Workumer buitenwaard staat onder invloed van het IJsselmeer. Hier liggen schelpenbanken en zandplaten, met daartussen ondiepten die periodiek droogvallen. Bij hoog peil en harde zuidwestenwind wordt een groot deel van de buitenwaard overstroomd. De buitenwaard wordt sinds 1958 in het zomerhalfjaar beweid met pinken en paarden (Slager \& Smit, 1989). Hierdoor is er geen beschermende rietkraag langs de waterkant gegroeid. 't Fryske Gea heeft de buitenwaard sinds 1958 in beheer.

De vegetatieontwikkeling op de voormalige intergetijde platen langs de Friese kust is slechts fragmentarisch gevolgd. Begin jaren ' 80 van de vorige eeuw is er door de Rijksdienst IJsselmeerpolders uitgebreid onderzoek gedaan naar bodem, hydrologie en vegetatie op de waarden langs de Friese IJsselmeerkust, om kennis te verzamelen ten behoeve van inrichting en beheer van drooggevallen zandgronden met bestemming natuur langs de Grevelingen, Lauwersmeer en Krammer-Volkerak (Slager \& Smit, 1989). Het beeld van de Workumer buitenwaard dat uit dat onderzoek naar voren komt is het volgende.

Hoogte reliëf en grondwaterstand in de Workumer buitenwaard zijn twee bepalende factoren voor de vegetatie. Voor de grondwaterstand is het microreliëf heel belangrijk in de Workumer buitenwaard (Slager \& Smit, 1989). De delen lager dan NAP zijn zompig. De hoogste delen liggen ongeveer op NAP hoogte, maar er zijn veel grote en kleine laagtes van 10 tot $30 \mathrm{~cm}$ diep. Deze staan 's winters vol water, omdat ze regelmatig overspoeld worden. Het water kan niet wegzijgen vanwege de slecht doorlatende ondergrond. Alleen in een langere droge periode verdampt er zoveel water dat ook de diepere gaten droogvallen. De delen boven NAP staat in de winter plas-dras. Ook hier is micro reliëf belangrijk, met kopjes met een oppervlakte van 1 tot $10 \mathrm{~m}^{2}$ die 5 tot $15 \mathrm{~cm}$ boven het omringende veld uitsteken (Slager \& Smit, 1989). De schelpbanken voor de plaatranden liggen het hoogst. Deze schuiven door golfwerking geleidelijk de plaat op (Kooistra, 1980).

De vegetatie van de Workumer buitenwaard is grotendeels grasland, met langs de oever zompig grasland en daarvoor enkele schelpenbanken (Slager \& Smit, 1989). In 1981 is er uitgebreid veldonderzoek gedaan naar de vegetatie in de Workumer buitenwaard (Andeweg \& Roog, 1982). Hierin worden verschillende vegetatiemilieus nader beschreven, behalve 
grasland zijn dit de zomerkade, zilte plekken, schelpenbanken, natte delen, sloten, plasjes en oevers. De vegetatie in grasland is weer te onderscheiden aan de hand van het microreliëf, te weten hoog, laag, zompig en kopjes. Op verschillende plekken in de Workumer buitenwaard is de invloed van zout in de bodem in de lage delen nog merkbaar aan de vegetatie, met soorten uit de zeeasterklasse. Dit zijn met name plekken die vaak begraasd en betreden zijn door koeien en die tevens matig vochtig zijn (Andeweg \& Roog, 1982; Slager \& Smit, 1989). 


\section{Building with Nature aanpak Friese IJsselmeerkust}

\subsection{Wat is Building with Nature?}

Building with Nature, in het Nederlands Bouwen met de Natuur, is een nieuw concept in waterbouwkundig ontwerpen waarbij natuurlijke elementen zoals wind, water (golven en stroming), vegetatie (flora) worden benut in het (waterbouwkundig) ontwerp. Hierdoor ontstaan tegelijk voordelen voor waterveiligheid, natuur, recreatie en andere sociaaleconomische functies en ambities. Het is een omslag in het denken over watergerelateerde infrastructuur. Essentieel hierbij is het besef dat een infrastructureel ontwerp meer dan één doel kan dienen, dat het ontwerp in lijn is met natuurlijke processen in plaats van ertegen in gaat, en dat het ontwerp om kan gaan met veranderende condities zoals zeespiegelstijging en klimaatverandering (de Vriend \& van Koningsveld, 2012). In Nederland wordt op meerdere plekken geëxperimenteerd met Building with Nature oplossingen voor waterveiligheid, in plaats van traditionele oplossingen. De bekendste zijn de Zandmotor bij Delfland, de pilot Houtribdijk langs de dijk Lelystad-Enkhuizen en de versterking van de Hondsbossche en Pettemer Zeewering. Al deze projecten hebben als doel om meer kennis te genereren over het toepassingsbereik van 'zachte' maatregelen, in het domein van traditionele, 'harde' fysieke infrastructuur. Meer informatie over alle projecten is te vinden op de website www.ecoshape.nl.

\subsection{Ecodynamische visie IJsselmeer}

Ook voor het IJsselmeergebied zijn er volop kansen voor Building with Nature. Voor het IJsselmeergebied is dit bredere denken over infrastructureel ontwerpen, waarbij gebruik wordt gemaakt van de ecosysteemdiensten die een systeem kan leveren, beschreven in een ecodynamische visie. Deze ecodynamische visie heeft de volgende uitgangspunten (Groot et al., 2012):

- een bijdrage leveren aan meerdere functies en ambities waaronder natuur, waterveiligheid, zoetwaterbeschikbaarheid, visserij, recreatie en infrastructuur;

- optimaal gebruik maken van de in het gebied aanwezige natuurlijke factoren als wind, water, sediment en vegetatie;

- oplossingen uitwerken tot adaptieve ontwikkelpaden met samenhangende pakketten van opschaalbare maatregelen die flexibel en robuust zijn: flexibel omdat ze mee kunnen meebewegen en robuust omdat ze relevant zijn onder verschillende omstandigheden;

- oplossingen realiseren door 'learning by doing';

- oplossingen realiseren door nieuwe vormen van op ondernemerschap gerichte samenwerking tussen publieke en private partijen;

- koppelen van (investerings)agenda's.

Opgaven vanuit het Deltaprogramma, zowel de waterveiligheidsopgave als de zoetwateropgave, zijn belangrijke drijvende krachten voor een ecodynamische ontwikkeling. Zachte maatregelen zoals vooroevers, drijvende moerassen, zandmotoren en achteroevers, geven kansen voor natuurontwikkeling, landschap en recreatie. Het versterken van de visserijsector door een duurzaam visserijbeleid kan hierop aanhaken (Groot et al., 2012).

In de ecodynamische visie is een kansenkaart opgenomen waarin de kansen voor ecodynamische ontwikkeling van het IJsselmeer zijn weergegeven (Figuur 3.1). 


\section{KANSENKAART}

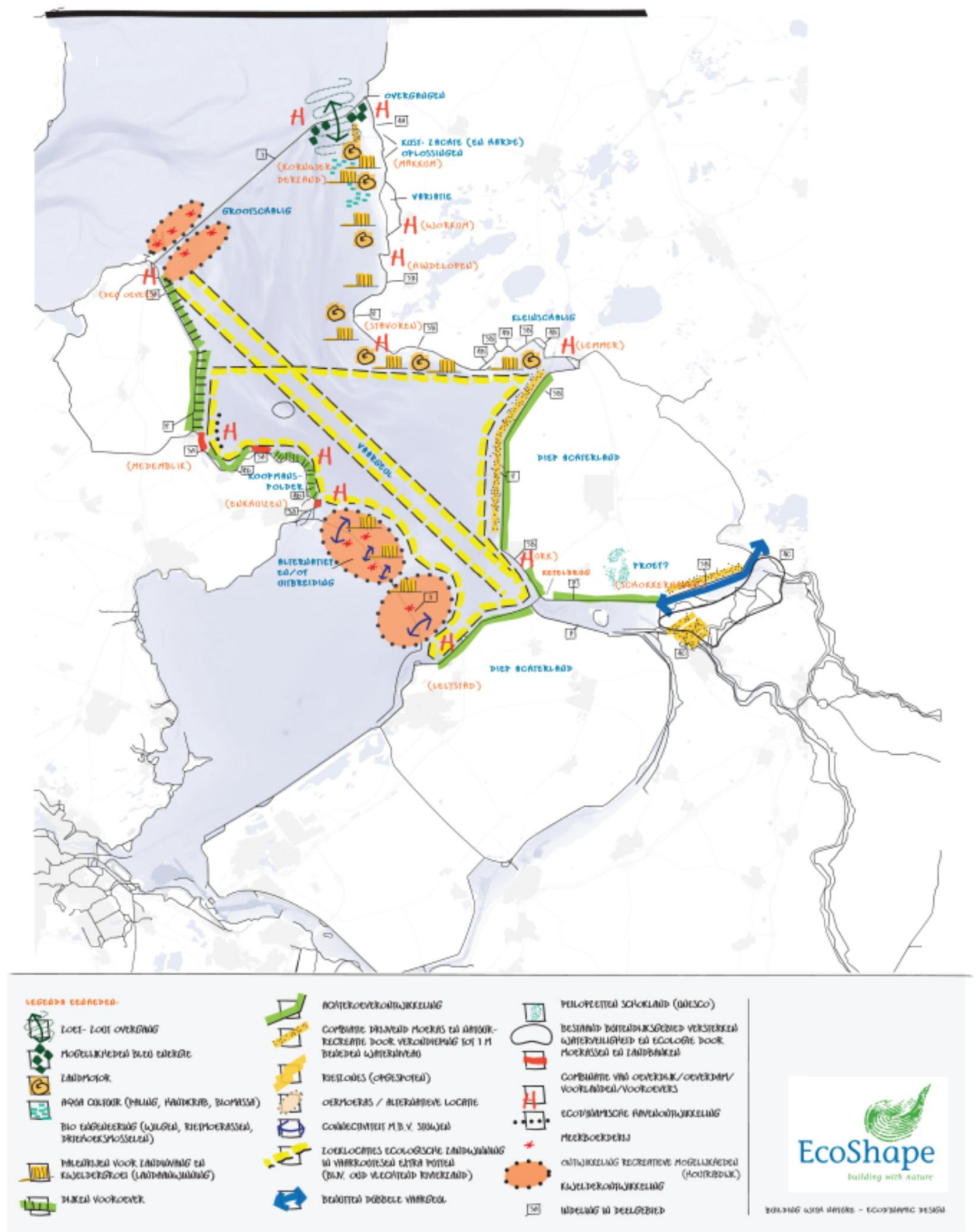

Figuur 3.1: Kansen voor ecodynamische ontwikkeling (overgenomen uit Groot et al., 2012)

\subsection{Ecodynamische bescherming Friese IJsselmeerkust}

De buitendijkse gebieden langs de Friese IJsselmeerkust zijn kwetsbaar voor erosie en komen bij zuidwesterstorm door opwaaiing onder water te staan. Door het nieuwe peilbeheer dat in het Deltaprogramma is voorgesteld dreigen bestaande natuurlijke waarden van de Friese kust te verdwijnen en worden sommige dijktrajecten extra kwetsbaar voor golfinslag en erosie. Tien centimeter peilstijging betekent dat ruim honderd hectare land onder water komt 
te staan. Zonder aanvullende maatregelen zullen grote delen van de buitendijkse gebieden door erosie verdwijnen.

Deze gebieden vertegenwoordigen grote belangrijke waarden voor natuur, recreatie en waterveiligheid. Daarom ontwikkelen betrokken partijen langs de Friese IJsselmeerkust - als nadere uitwerking van de Deltabeslissingen - een adaptatiestrategie voor een duurzame kustbescherming. De opgave is om de Friese IJsselmeerkust dermate veerkrachtig te maken, dat het de negatieve gevolgen van het verhoogde waterpeil op kan vangen. Ook als het waterpeil in de toekomst nog verder omhoog gaat.

Het kiezen voor een ecodynamische bescherming van de Friese IJsselmeerkust biedt een uitgelezen manier voor het combineren van natuur, veiligheid, recreatie en andere functies. Een ecodynamisch ontwerp laat de natuurlijke processen zo veel mogelijk hun gang gaan, waarbij de gewenste processen worden gestimuleerd, en de ongewenste processen geremd.

De verwachting is dat succesvolle ecodynamische oplossingen in de toekomst de Friese kust veilig houden tegen overstromingen, de natuur behouden en de recreatie een verdere impuls geven. Echter, realisatie van deze doelstelling vereist een gedegen kennis van de natuurlijke krachten, en van de maatschappelijke eisen en wensen. Om de huidige kennisleemtes in het kader van ecodynamische kustbescherming van de Friese IJsselmeerkust te vullen, zijn pilot experimenten uitgevoerd. Doel van deze pilots is het genereren van kennis die bijdragen aan het onderbouwen van een strategie voor een ecodynamische bescherming van de Friese IJsselmeerkust. Tevens zullen deze pilots bijdragen aan het vergroten van het draagvlak voor ecodynamische kustbescherming (Folmer et al., 2010).

\subsection{Het concept zandmotor}

Eén van de ecodynamische maatregelen voor kustbescherming volgens de principes van Building with Nature is de zandmotor. Zandsuppleties in de vorm van een 'zandmotor' zijn een zachte vorm van kustverdediging. Daarbij wordt een grote hoeveelheid zand op een doordachte locatie voor de kust aangebracht zodat natuurlijke processen het zand verspreiden naar het gebied waar het zand het meest nodig is (Figuur 3.2; Groot et al., 2012).

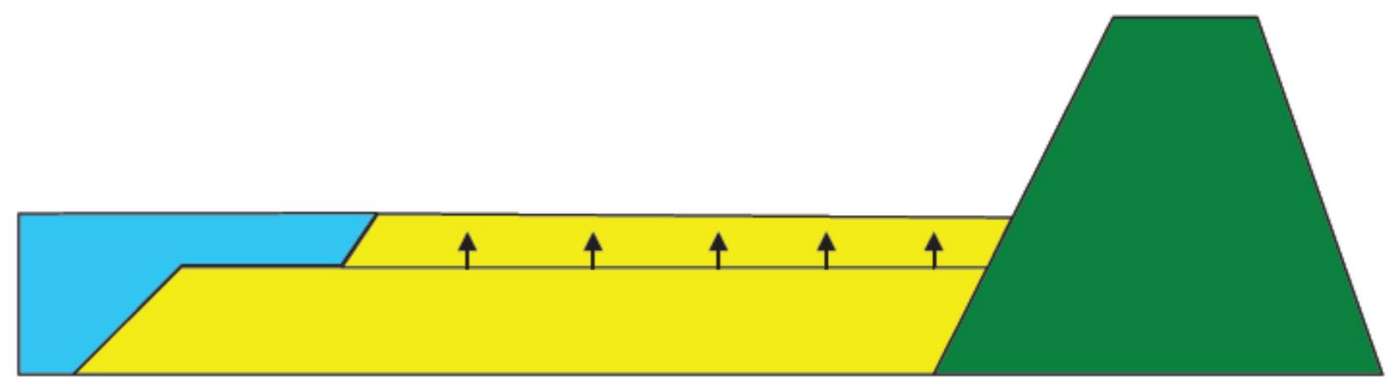

Figuur 3.2: Zandmotor (bron: Fiselier et al, 2011)

Het concept 'zandmotor' is voor het eerst op grote schaal toegepast aan de Zuid-Hollandse kust bij Delfland (Figuur 3.3). Daar is in 2011 een geconcentreerde zandsuppletie van 21.5 miljoen $\mathrm{m}^{3}$ aangelegd die tot 5 meter boven zeeniveau is aangelegd. Deze strategie van geconcentreerde mega-suppletie wordt gezien als een klimaatrobuuste en natuurvriendelijke oplossing van het tegengaan van kusterosie, en wordt 'zandmotor' genoemd. Door in één keer een surplus aan zand aan te brengen, in plaats van 5-jaarlijks een kleinere hoeveelheid, 


\section{$\underbrace{}_{-3} \frac{\text { ALTERRA }}{\text { WAGENINGENUR }}$}

wordt de verstoring van het ecosysteem beperkt. De natuur krijgt daarmee langer de tijd om te herstellen en/of te ontwikkelen, wat een positief effect op de biodiversiteit heeft. Vanuit de geconcentreerde suppletie wordt het zand door de natuurlijke processen geleidelijk verdeeld over de vooroever, strand en duinen. Tegelijkertijd brengt het (tijdelijke) surplus van zand ook nieuwe gebieden voor natuur en recreatie met zich mee.

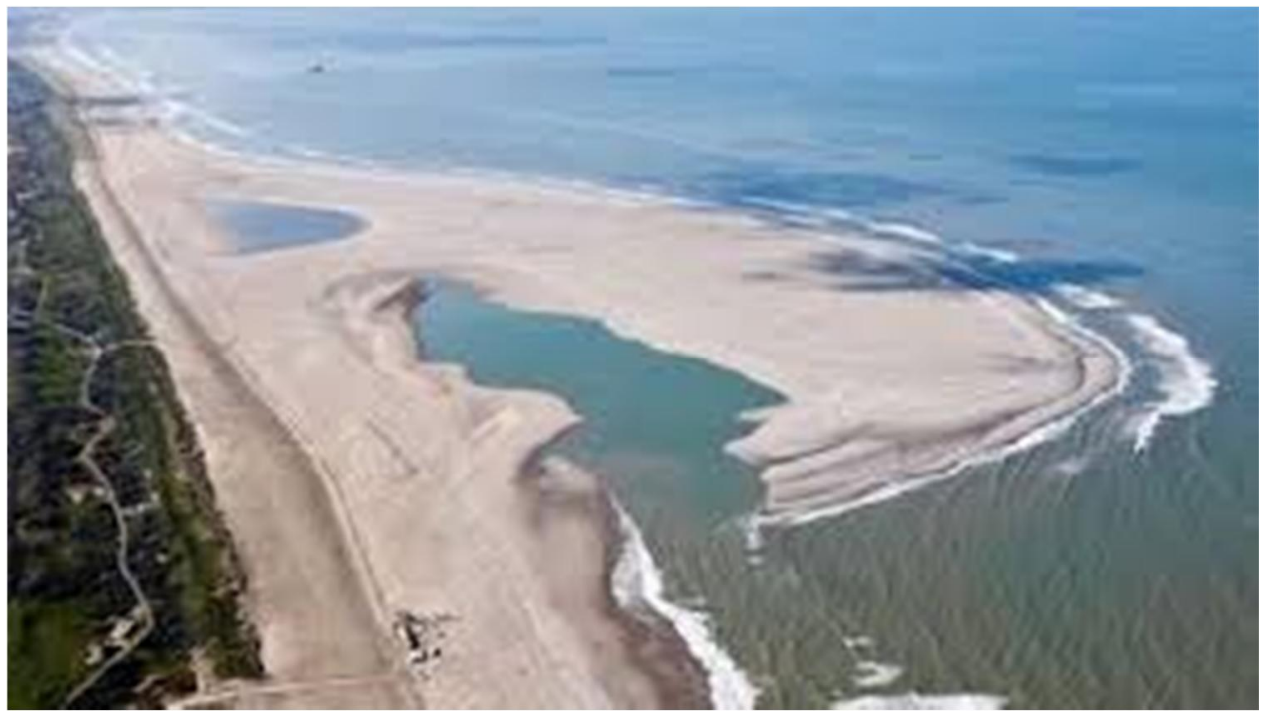

Figuur 3.3: Zandmotor Zuid-Hollandse kust bij Delfland (foto: Joop van Houdt, RWS)

De zelfde uitgangsprincipes kunnen mogelijk worden toegepast langs de Friese IJsselmeerkust. Voor dergelijke laag-dynamische milieus is echter minder kennis beschikbaar. 


\section{Werkwijze pilots Zandmotor Friese IJsselmeerkust}

\subsection{Drie Pilots Friese IJsselmeerkust}

Om de potentie van zandmotoren langs deze kust te onderzoeken is in 2010 het project Zachte zandmotor Friese IJsselmeerkust opgestart. Op twee locaties zijn experimenten uitgevoerd naar manieren om de kust op een natuurlijke manier mee te laten groeien (Figuur 4.1) en op een derde locatie (Hindeloopen) is een modelstudie uitgevoerd. De experimenten bestaan uit kleinschalige suppleties van zand op de ondiepe vooroevers van het IJsselmeer. De hypothese is dat dit zand door golven naar de kust wordt gebracht en daar de (voor)oevers versterkt. Het zandmotorconcept moet tot een duurzamer, goedkoper en ecologisch robuuster resultaat leiden dan de bestaande kunstmatige eilanden en harde vooroevers in het IJsselmeer. Om dit te testen is een uitgebreid monitoringprogramma opgezet dat de effecten van de zandmotoren in het IJsselmeer volgt.

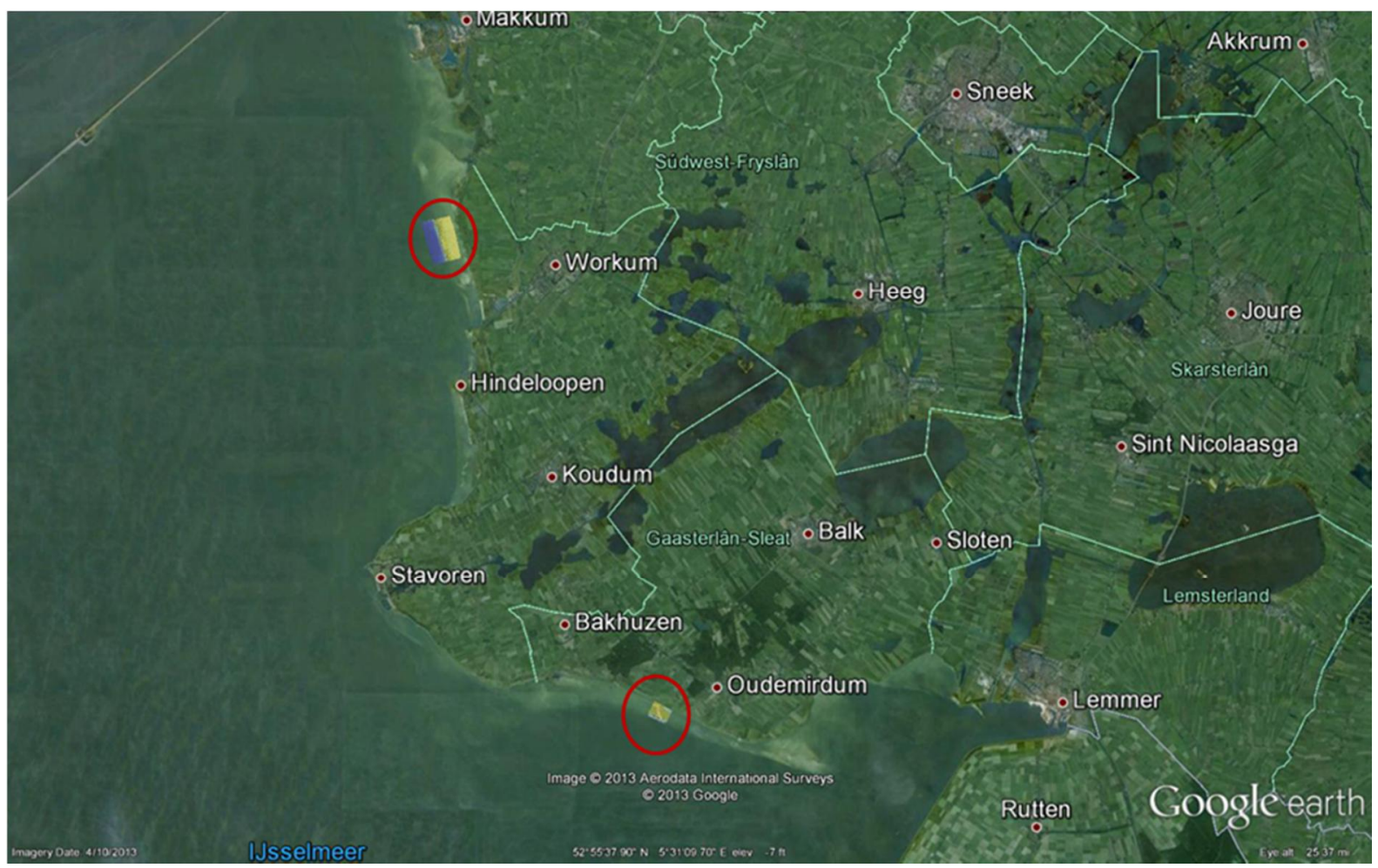

Figuur 4.1 Locaties zandmotoren

\subsection{Monitoringsprogramma}

De pilots zijn bedoeld om kennis op te doen van het systeem en de effectiviteit van de zandmotor, Hiervoor is een monitoringsprogramma opgezet dat loopt van $2011 \mathrm{t} / \mathrm{m} \mathrm{2017}$. De monitoring is gericht op het begrijpen het gedrag van de zandmotor, de effecten op de kust (en daarmee waterveiligheid) en op de ecologie (Figuur 4.2, Tabel 4.1). 
Het monitoringsprogramma heeft als doel de volgende onderzoeksvragen te beantwoorden:

- Hoe verspreidt het zand zich en hoe snel beweegt het zand?

- Welke weersomstandigheden domineren veranderingen?

- Wat is het effect van de zandmotor op de kust?

- Wat zijn de effecten van de zandmotor op de ecologie zowel onder als boven water?

- Doelbereik waterveiligheid?

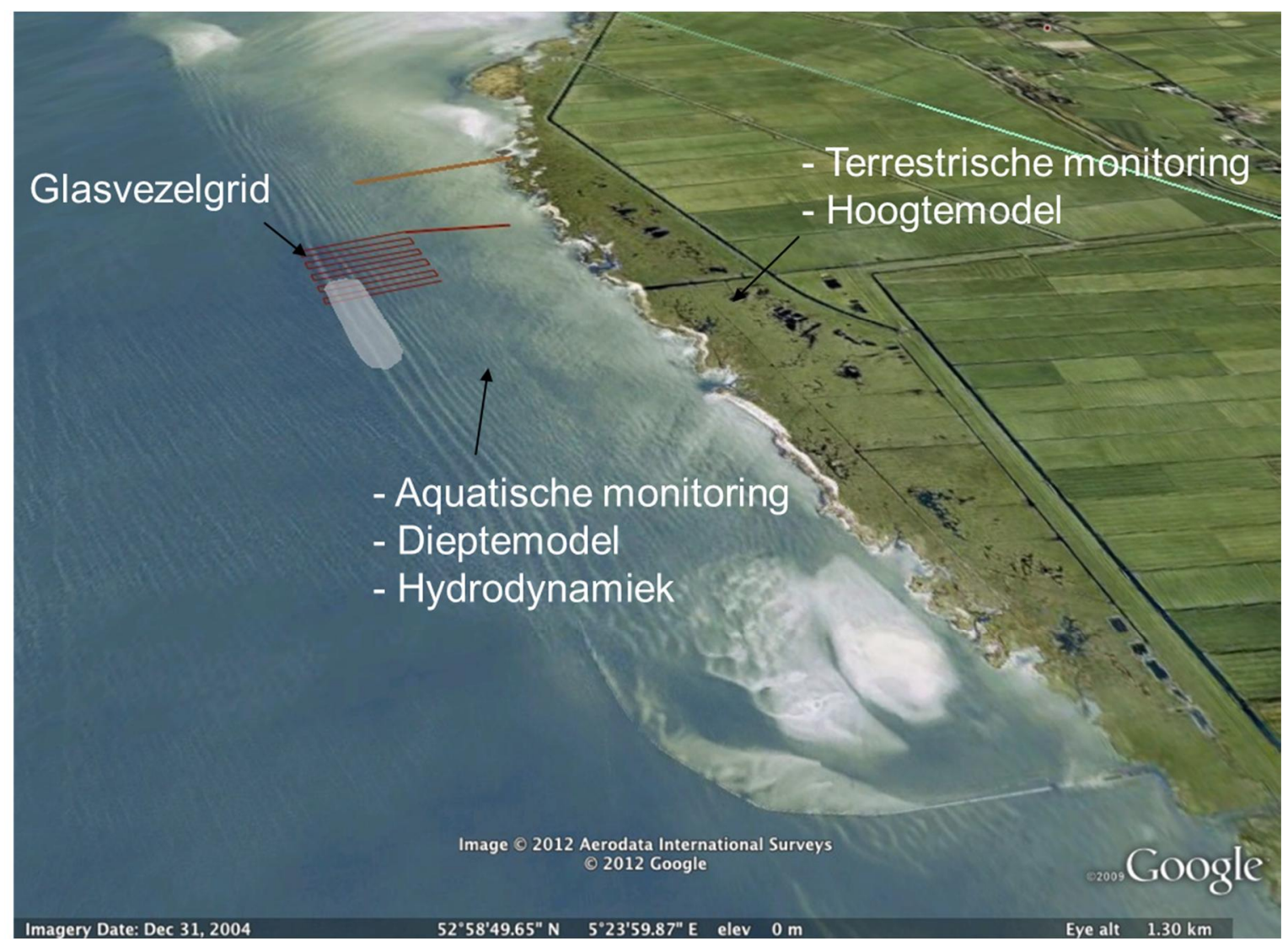

Figuur 4.2 Overzicht van de monitoring bij de Workumerwaard.

Tabel 4.1: Uitgevoerde metingen

\begin{tabular}{|l|l|l|l|l|l|l|}
\hline Workum & bathymetrie & $\begin{array}{l}2011 \\
\text { april T0, } \\
\text { okt T1 }\end{array}$ & $\begin{array}{l}\text { april T2, } \\
\text { okt T3 }\end{array}$ & juni T4 & juli T5 & mei T6 \\
\hline & LIDAR $^{1}$ & T0 & T1 & & & T2 \\
\hline & $\begin{array}{l}\text { aquatische } \\
\text { vegetatie }\end{array}$ & T0 & T1 & T2 & T3 & T4 \\
\hline & $\begin{array}{l}\text { terrestrische } \\
\text { vegetatie }\end{array}$ & T0 & T1 & & & T2 \\
\hline & DTS & $\mathrm{x}$ & $\mathrm{x}$ & & & mei T4 \\
\hline Oudemirdum & $\begin{array}{l}\text { Morfologie } \\
\end{array}$ & & okt T0 & $\begin{array}{l}\text { april T1, } \\
\text { nov T2 }\end{array}$ & april T3 & me15 \\
\hline & $\begin{array}{l}\text { aquatische } \\
\text { vegetatie }\end{array}$ & & T0 & T1 & & T2 \\
\hline
\end{tabular}

1) LIDAR meting ook van 2008 beschikbaar 


\section{Morfologie en hoogtemetingen}

Door landhoogtes in te meten met laseraltimetrie (LiDAR), en onderwater de bathymetrie in te meten met dGPS en echolood metingen, worden de morfologische veranderingen rond de suppletie in detail gevolgd. Hieruit wordt duidelijk hoe en waarnaartoe het zand zich verplaatst. In Workum is er ook een innovatieve experimentele opstelling gebruikt, met glasvezel Distributed Temperature Sensing (DTS), om de morfologische veranderingen op gedetailleerde tijdschaal te volgen.

\section{Ecologie}

Om de effecten van de zandmotor op de ecologie vast te stellen is bij zowel Workum als Oudemirdum jaarlijks de aquatische ecologie gemonitord. Daarnaast is de terrestrische ecologie in de Workumerwaard gemonitord om mogelijke invloeden van de zandmotor bij Workum op de terrestrische vegetatie in de Workumerwaard te kunnen vaststellen.

\subsection{Zandmotor bij Workum}

Het buitendijkse natuurgebied de Workumerwaard is kwetsbaar voor erosie en staat bij storm onder water. Dit gebied vertegenwoordigt belangrijke waarden voor natuur en recreatie en heeft vanwege de golfremmende werking een belangrijke waarde voor de waterveiligheid van het binnendijkse gebied. Door het voorgestelde nieuwe peilbeheer van het IJsselmeer en zeker als het peil in de toekomst nog verder omhoog moet zullen grote delen van dit gebied door erosie verdwijnen. Om die reden is gekozen voor Workum als geschikte locatie voor experimenten met de zandmotor.

De zandmotor bij Workum is in oktober 2011 opgeleverd. Deze kustparallelle suppletie bestaat uit een reep zand van 100 meter bij 600 meter parallel aan de kust. Het volume zand dat is aangebracht is ongeveer $31.000 \mathrm{~m}^{3}$ en de suppletie ligt op ongeveer 600 meter afstand van de kust en op enkele tientallen meters van het steile talud dat de overgang vormt naar dieper water. In het noorden van het gebied is een palenrij aangelegd met als doel het sediment in het gebied te houden (Figuur 4.3). De experimenten bij Workum moeten aantonen of de zandmotor een effectieve maatregel is om de buitendijkse natuurgebieden te beschermen. 

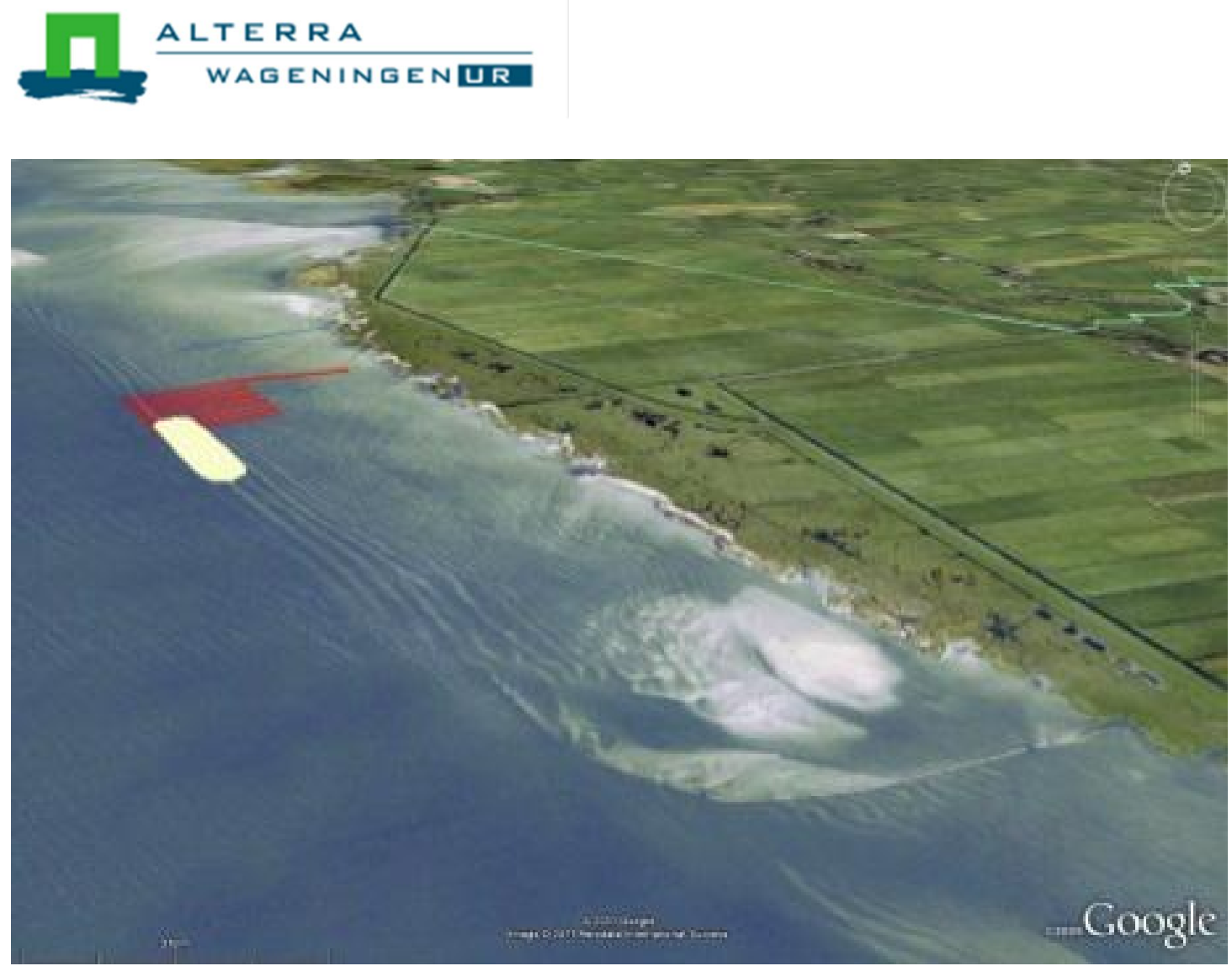

Figuur 4.3: De zandmotor bij Workum (overgenomen uit Wiersma et al., 2013).

\subsection{Zandmotor bij Oudemirdum}

Bij Oudemirdum is de primaire waterkering afgekeurd. Experimenten met de zandmotor moeten hier uitwijzen of deze strategie kan bijdragen aan de waterveiligheid van het gebied door het versterken/creëren van een vooroever waardoor de belasting op de primaire waterkering zal afnemen.

De zandmotor bij Oudemirdum bestaat uit een haak dwars op de kust van $11.500 \mathrm{~m} 3$ zand en is begin 2013 opgeleverd. De haak begint ongeveer 50 meter van de kust aan de noordzijde en eindigend aan de zuidkant op ongeveer 400 meter van de kust. De overgang naar dieper water ligt op zo'n 200 meter afstand van de suppletie (Figuur 4.4). 


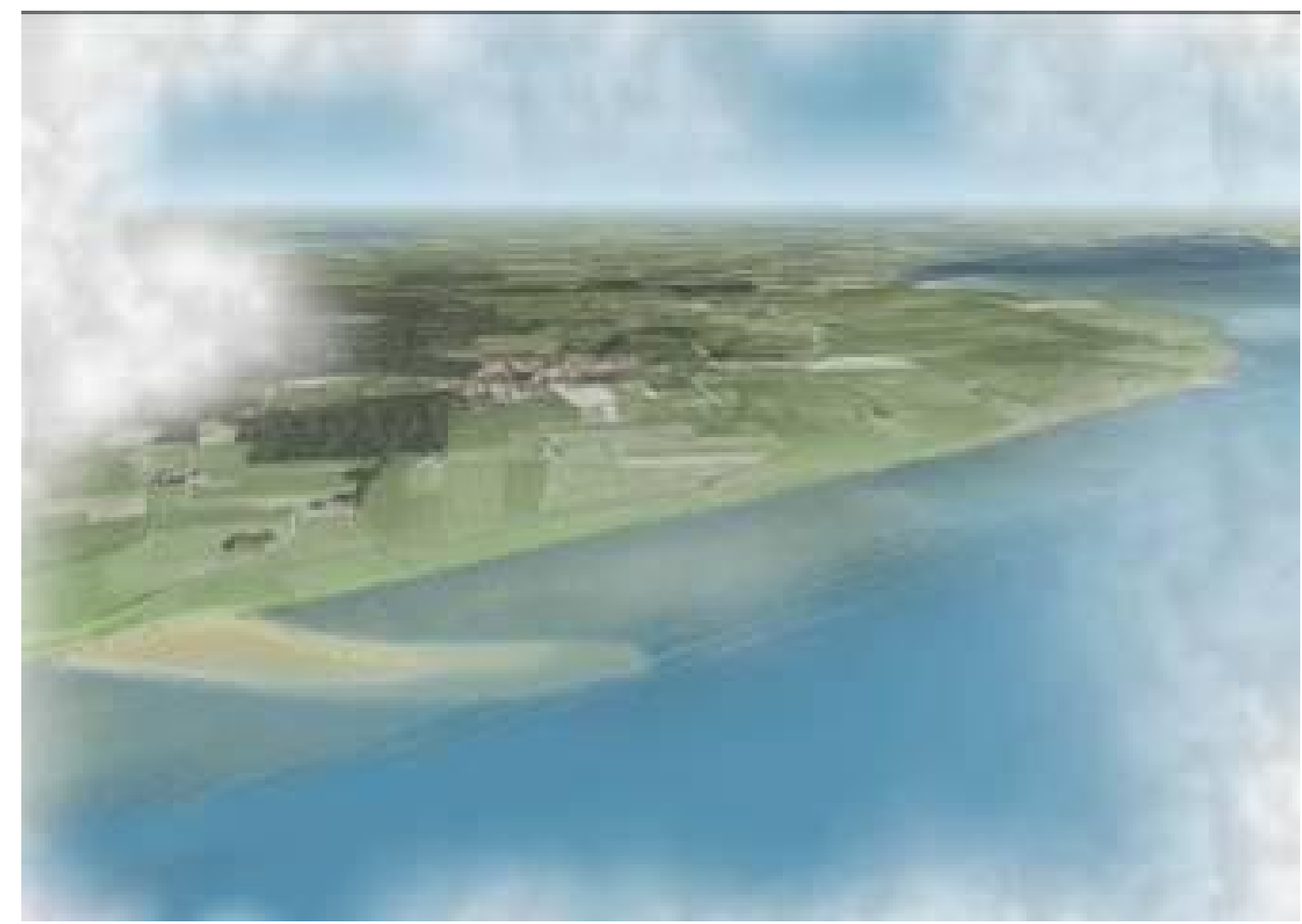

Figuur 4.4: Artist impression van de zandmotor bij Oudemirdum (bron: Ecoshape, 2011)

\subsection{Pilot Hindeloopen}

Een derde pilot was voorgesteld bij Hindeloopen. In Hindeloopen liggen economische en recreatie belangen zoals strandtoerisme, kite-surfers en recreatieve vaart. De stranden in Hindeloopen zijn sterk onderhavig aan erosie en de vaargeul naar de jachthaven moet regelmatig gebaggerd worden. Stakeholders geven aan kansen te zien voor en meerwaarde te zien van ecodynamische oplossingen.

In samenspraak met de betrokken partijen is besloten geen fysieke pilot uit te voeren bij Hindeloopen omdat men van mening was dat er nog onvoldoende kennis is van het hydromorfologische systeem. Daarom is besloten een modelstudie uit te voeren met als doel het bepalen van maatgevende processen en het verkennen van duurzame en ecologisch robuuste maatregelen (Witteveen+Bos, 2014). We geven hier de belangrijkste uitkomsten van deze modelstudie.

Op basis van inzicht in de waterbeweging en resultaten uit het historisch onderzoek zijn drie scenario's bepaald om de kwaliteit van de Friese kust op het traject Molkwerum - Workum te versterken. De scenario's zijn het resultaat van gesprekken met de opdrachtgever en stakeholders en dienen als voorbeeld. Hierbij zijn de volgende uitgangspunten (afkomstig uit de historische analyse) gehanteerd:

- $\quad$ aanzanding van de havengeul bij Hindeloopen kan beperkt worden door het langstransport te verminderen of te onderbreken;

- het netto sedimenttransport is noordwaarts gericht;

- het zand voor de kust van Hindeloopen kan alleen vastgehouden worden door een combinatie van langs- en dwarsdammen waardoor de invloed van golven vermindert. 


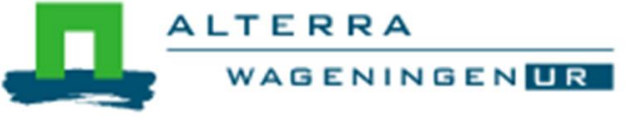

Scenario 1 bestaat uit een strekdam langs de havengeul van Hindeloopen (Figuur 4.5). Dit scenario is bedoeld om de sedimentatie in de havengeul te verminderen. Door de havendam zal de sedimentatie in de geul afnemen. Dit is positief voor de (plezier)vaart. Ten noorden van de havengeul zal de sedimentatie toenemen als gevolg van het toegenomen langstransport. Dit kan ertoe leiden dat er ondanks dat het baggervolume afneemt, toch vaker gebaggerd moet worden. De erosie voor de havengeul zal iets toenemen, maar dat heeft geen gevolgen voor de waterveiligheid. Het scenario heeft geen effect op de kust bij Hindeloopen, de natuurwaarden en de landschappelijke kwaliteit.

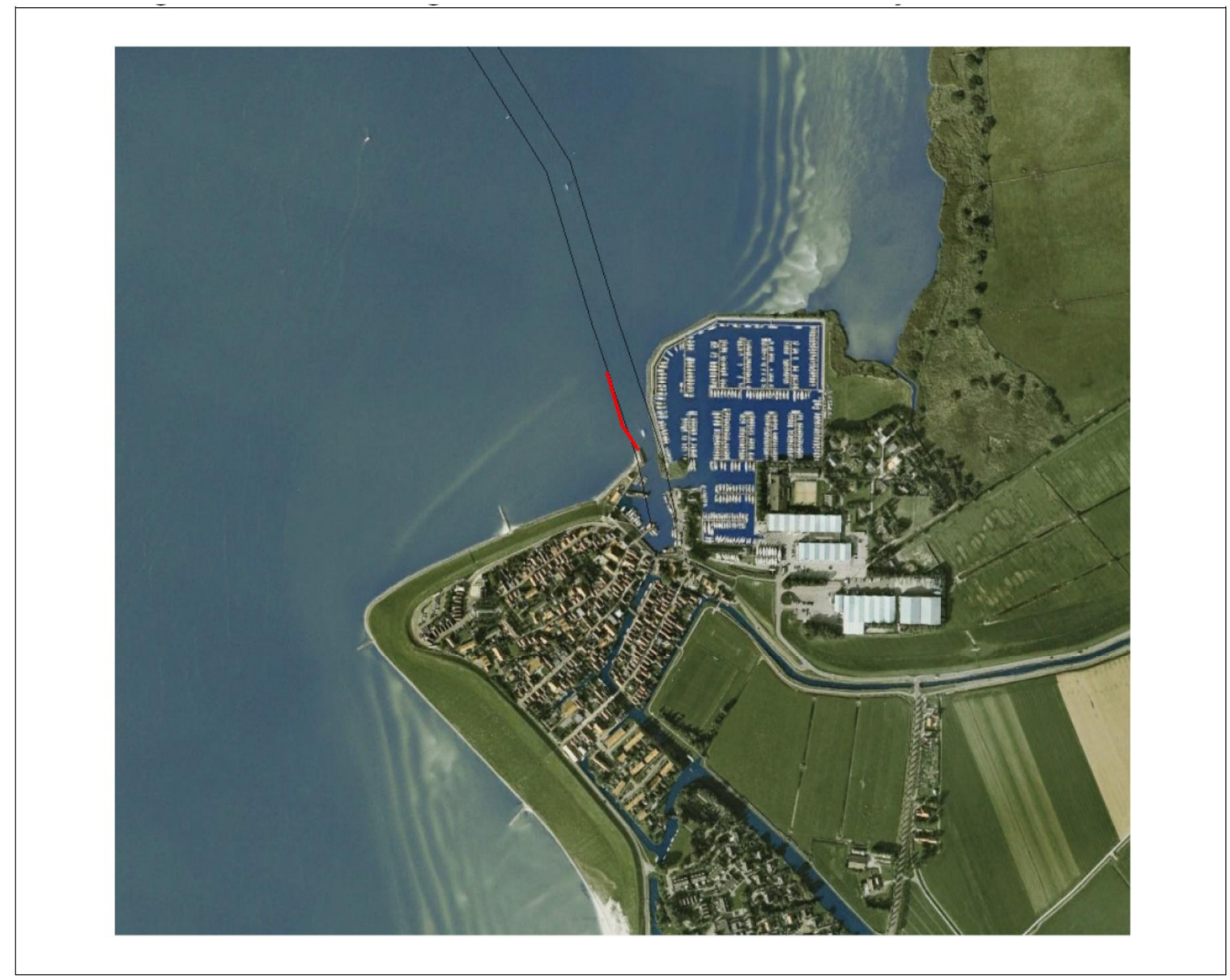

Figuur 4.5: Scenario 1 modelstudie Hindeloopen - strekdam havengeul. 
Scenario 2 is het ondernemersscenario en bestaat een strekdam ter hoogte van de kop van Hindeloopen en ten zuiden van de strekdam tot aan het badpaviljoen Hindeloopen wordt een strand van $100 \mathrm{~m}$ breed aangelegd (Figuur 4.6). Het strand wordt zeewaarts gestabiliseerd met een strook geotubes (Figuur 4.7). Deze variant heeft vanwege het grotere strand een positief effect op de strandrecreatie. Dit geldt zowel voor de strandgasten alsook de (kite)surfers die een breder strand krijgen. Op natuur heeft het een negatief effect, vanwege het afnemen van de natuurlijke dynamiek van het strand. Het baggerbezwaar in de vaargeul neemt nauwelijks af. Het scenario zorgt voor het tegengaan van erosie en een blijvende versterking van de Friese Kust, wat positief is voor de waterveiligheid.

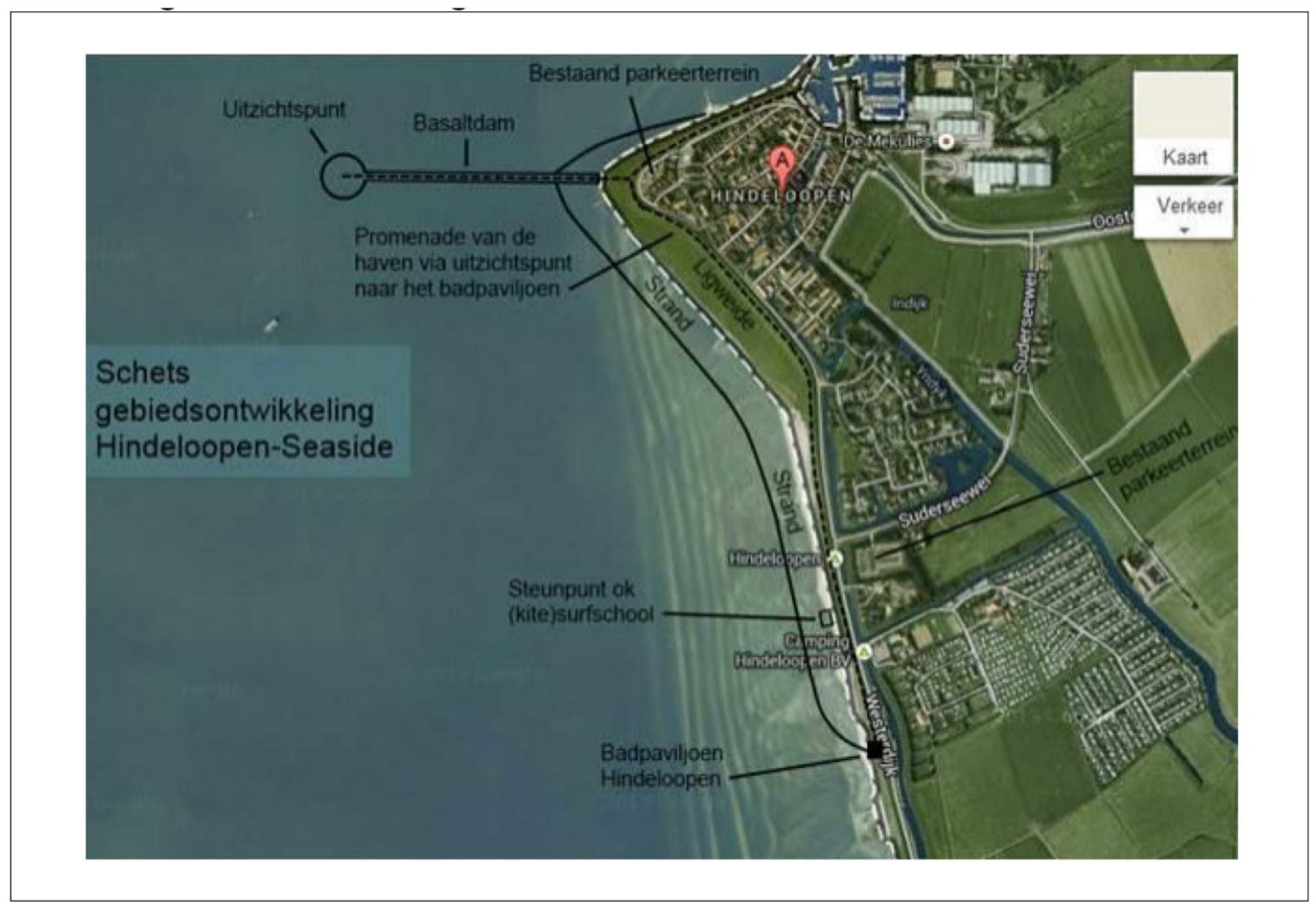

Figuur 4.6: Scenario 2 modelstudie Hindeloopen - strekdam kop Hindeloopen en aanleg strand.

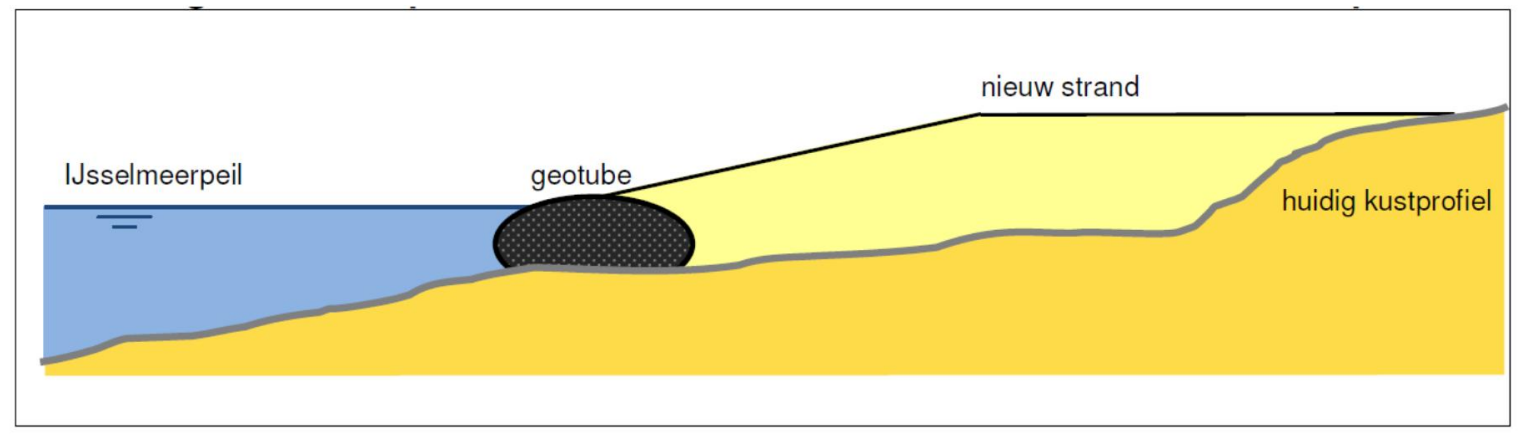

Figuur 4.7: Dwarsprofiel nieuwe strand ten zuiden van Hindeloopen.

Scenario 3 is het Building with Nature scenario. Deze oplossing bestaat uit ophogen van de ondiepte in het verlengde van de kop van Hindeloopen in noordoostelijke richting die afgedekt 
wordt met biezen matten (Figuur 4.8). Doel van de dam bij de havengeul is om het langstransport verder van de kust te laten plaatsvinden waardoor de sedimentatie in de havengeul afneemt. Langs de zuidkust worden op circa $150 \mathrm{~m}$ vanaf het strand vier langsbermen van biezenmatten aangelegd parallel aan de kust. Deze steken boven het water uit om golven zoveel mogelijk te reduceren.

Het baggerbezwaar van de vaargeul zal afnemen wat positief is voor de (plezier)vaart. De waterveiligheid achter de dammen wordt beter, maar ter plaatse van de openingen zal door de erosie (rip currents) de veiligheid iets afnemen. De natuurkwaliteit en landschappelijke kwaliteit neemt toe door het gebruik van biezenmatten, waarop mogelijk extra vegetatie zich kan ontwikkelen. De strandrecreatie en natuur zullen iets profiteren van de luwtes die ontstaan achter de dammen, waardoor de erosie van de kust tegengegaan wordt en er luwtezones voor vogels en vissen ontstaan. Dit scenario scoort beter op het vlak van natuurwaarden en landschappelijke waarden dan scenario 2, maar minder goed op recreatie en waterveiligheid.

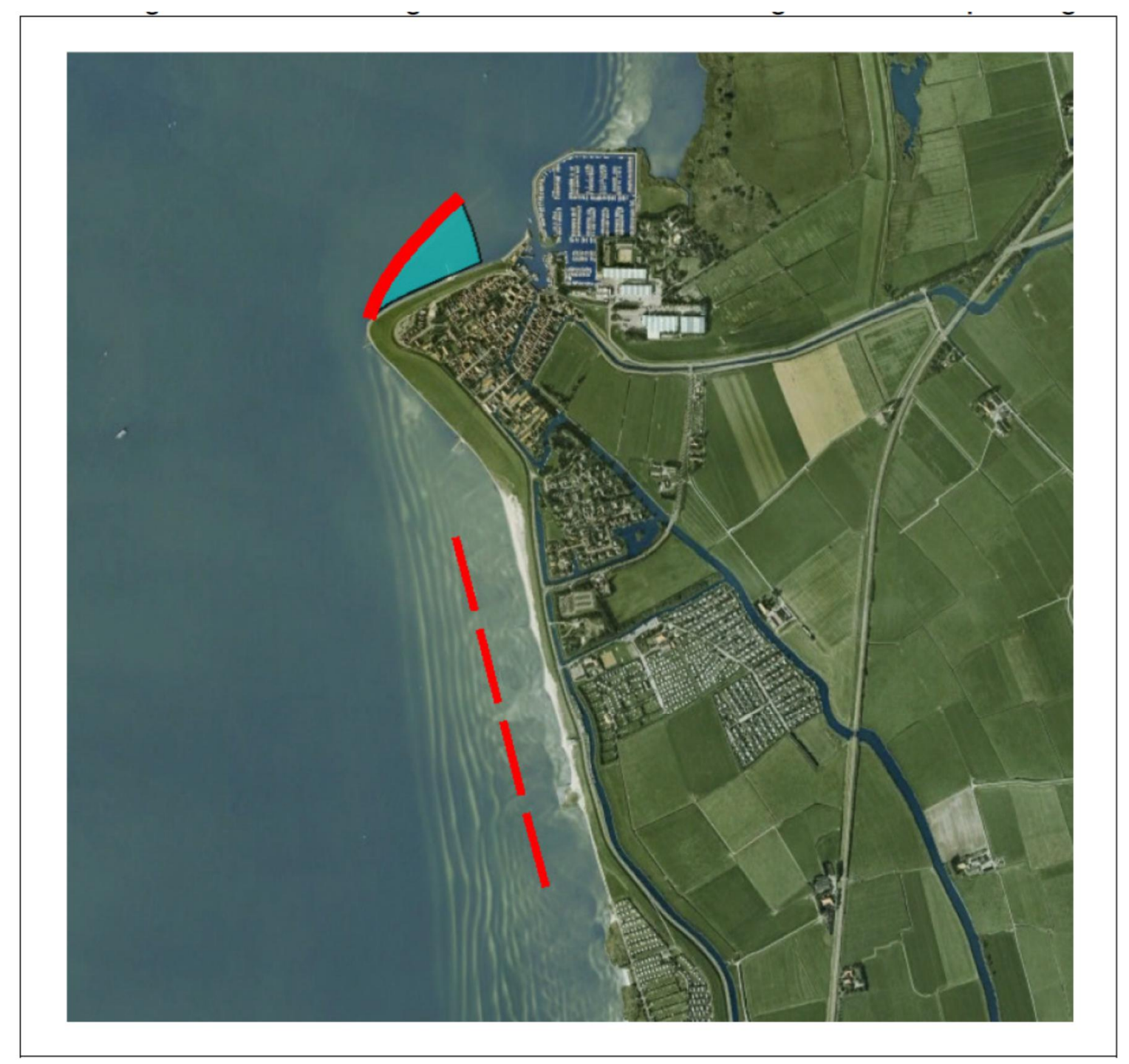

Figuur 4.8 Scenario 3 modelstudie Hindeloopen - Building with Nature scenario. 
Verwacht mag worden dat scenario 3 het meest toekomstbestendig is omdat deze zachtere maatregelen beter kunnen meegroeien met toekomstige peilveranderingen dan de harde maatregelen van scenario 1 en 2 (Witteveen+Bos, 2014).

De resultaten van de modelstudie zijn in 2014 gepresenteerd aan betrokken partijen. Het modelinstrumentarium is niet geschikt om absolute hoeveelheden van erosie of sedimentatie (zoals baggeronderhoud) of om de kustdwarse processen goed te voorspellen. Dit komt tot uitdrukking in de reproductie van de morfologie langs de kust van Hindeloopen, die tegenvalt. Voor een goede interpretatie van kustdwarse processen blijft daarom expert judgement nodig. Het is aan de regionale partijen om met deze resultaten een vervolgtraject in te zetten om te komen tot een toekomstbestendige kust bij Hindeloopen. 


\section{Resultaten monitoring zandmotoren Friese IJsselmeerkust}

\section{$5.1 \quad$ Inleiding}

In dit hoofdstuk worden de resultaten van de monitoring van de zandmotor bij Workum en Oudemirdum in de periode $2011 \mathrm{t} / \mathrm{m} 2015$ beschreven. De monitoring loopt ook na 2015 nog door. Omdat er in 2016 een MIRT-preverkenning start met als doel het vaststellen van compenserende maatregelen langs de Friese IJsselmeerkust voor het veranderende peilregime van het IJsselmeer zijn de resultaten tot en met 2015 gepubliceerd in dit rapport. Eind 2017 worden de definitieve resultaten gerapporteerd.

\subsection{Resultaten pilot zandmotor Workum}

5.2.1 Hoe verspreidt het zand zich en hoe snel beweegt het zand?

De resultaten van de meetcampagne bij Workum zijn uitgebreid beschreven in Bijlage A. De zandmotor bij Workum is aangelegd in het gebied met parallelle zandruggen. Van de zandmotor bij Workum zijn op zeven momenten dieptemetingen uitgevoerd. In de eerste twee jaar is ieder half jaar gemeten, in de periode daarna ieder jaar. Uit de metingen blijkt dat de zandmotor geleidelijk wordt opgenomen in de kustparallelle zandruggen (Figuur 5.1 en Figuur 5.2). Het zand verplaatst zich richting het noorden. Kustwaarts is nauwelijks sedimentatie zichtbaar in de metingen.

De metingen laten wel zien dat het talud geleidelijk richting het westen uitbouwt ten noorden van de suppletie. Dit is in overeenstemming met de algemene trend die ook uit luchtfoto's naar voren komt (zie ook Figuur 2.4). Opvallend genoeg wijkt juist op de locatie waar de suppletie is aangelegd het talud wat terug richting de kust.

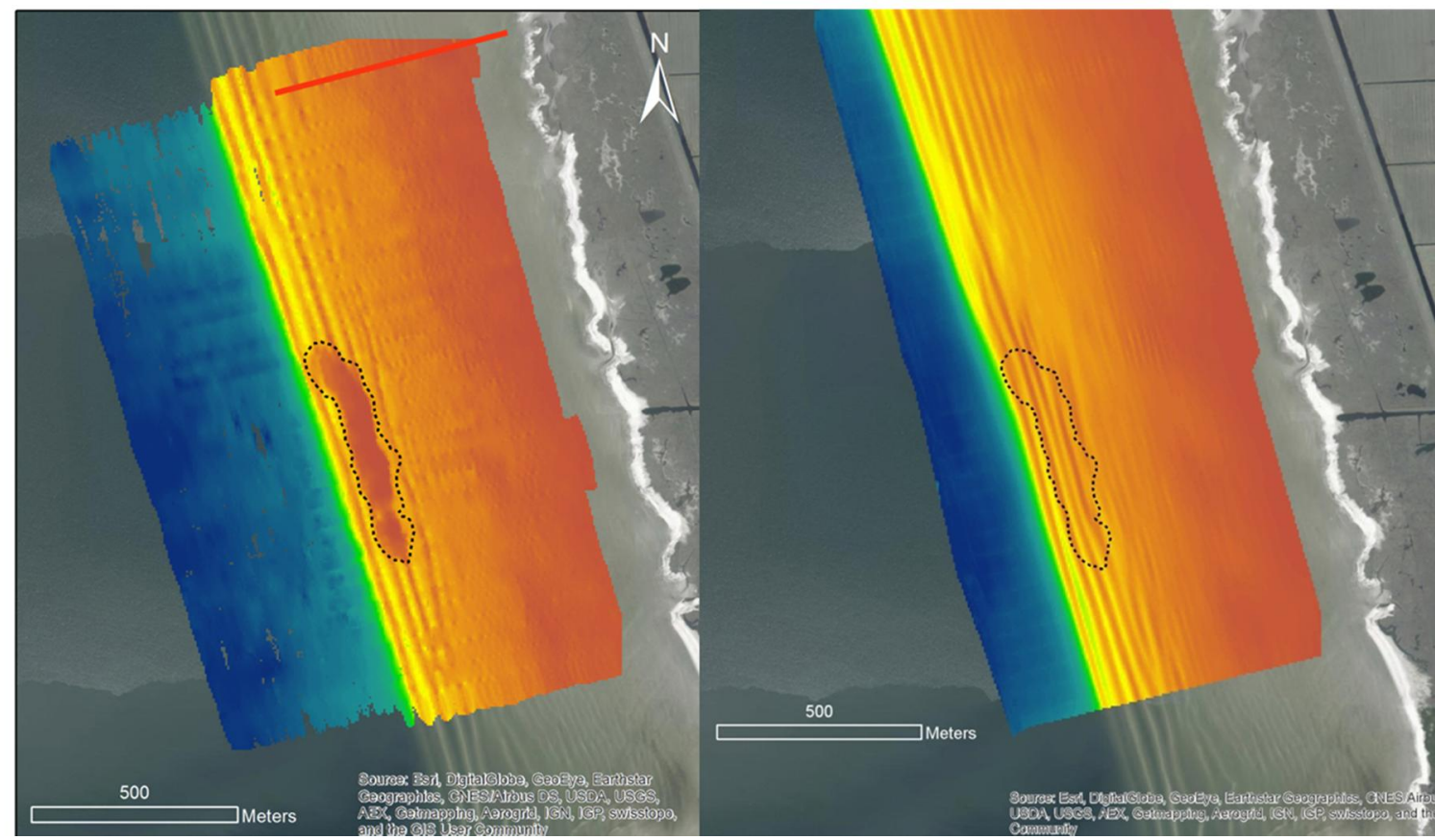

Figuur 5.1 Hoogtemodel van de suppletie bij Workum links) T1 opname vlak na de aanleg, rechts) T6 opname vier jaar na aanleg. 


\section{$-\frac{A L T E R R A}{\text { WAGENINGENUR }}$}

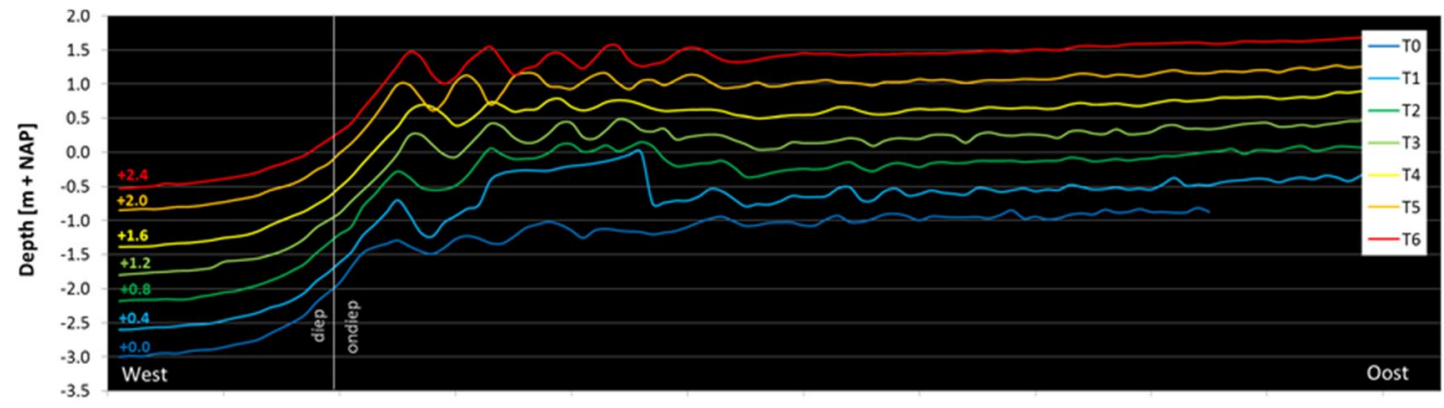

Figuur 5.2 Ontwikkeling van het kustprofiel en de suppletie bij Workum in zeven tijdstappen langs een West - Oost profiel. Tijdstap TO is de uitgangssituatie, tijdstap T1 is de tijdstap na de aanleg van de suppletie. De daarop volgende tijdstappen laten de evolutie van het kustprofiel zien. leder profiel is $40 \mathrm{~cm}$ omhoog geplaatst om de veranderingen te illustreren. Voor de locatie van het profiel wordt verwezen naar Bijlage $A$.

De temperatuurmetingen met glasvezel meten de zandbedekking iedere 4 uur. Het idee van deze resolutie is dat de morfologische veranderingen tijdens stormen kunnen worden gemeten. Tijdens de meetperiode hebben zich echter geen stormen voorgedaan. Wel laten de metingen zien dat de zandruggen geleidelijk kunnen verplaatsen met een snelheid van rond de $10 \mathrm{~m}$ in een periode van 30 dagen (Wiersma et al., 2013). Dit laat zien dat er geleidelijke morfologische veranderingen optreden buiten stormen om.

\subsubsection{Effecten op de kust}

Er zijn vier hoogtemetingen van de Workumerwaard beschikbaar. De eerste, uit 2008, is beschikbaar gesteld door Wetterskip Fryslân. De metingen van 2011, 2012 en 2015 zijn ingewonnen in het kader van het project Zachte Zandmotor langs het IJsselmeer. Tussen 2008 en 2011 zijn er nauwelijks veranderingen gemeten langs de kustlijn. De strandwal langs de kust ligt vrijwel op dezelfde plaats, en de hoogteligging van het achterliggende gebied is vrijwel gelijk. Tussen 2011 en 2012 zijn er wel grote verschillen opgetreden: De strandwal is landwaarts verplaatst en een aantal kreken die door de strandwal heen staken zijn deels verzand. De landwaartse verplaatsing van de strandwal is lokaal $30 \mathrm{~m}$.

Tussen 2012 en 2015 is de strandwal verder landwaarts verplaatst en zijn de kreken verder verzand. In vier jaar tijd (van 2011 tot 2015) heeft lokaal meer dan 30 meter landwaartse verplaatsing van de kust plaatsgevonden (Figuur 5.3). De grootste terugslag is waarschijnlijk het gevolg van een storm in de eerste week van 2012 (Wiersma et al., 2013). De kust wordt geleidelijk rechter. De onbegroeide strandwallen langs dit stuk kust zijn typisch voor eroderende of dynamische kustlijnen.

Opvallend is dat op de luchtfoto's de strandwallen die worden beschermd door de dam in het zuiden wel begroeid zijn. Dit suggereert dat golfbrekende maatregelen een positief effect hebben op het afkalven van de kust. Langs de overige Friese IJsselmeerkust komen nauwelijks vergelijkbare onbegroeide strandwallen voor, wat suggereert dat dit probleem van afkalving voornamelijk bij de Workumerwaard speelt. Dit is ook waargenomen door Menke en Lenselink (1998) voor de periode van 1949 tot 1989.

De pilot zandmotor heeft geen duidelijke effecten op de kustlijn. De kustlijn die beschermd wordt door de zandmotor vertoont over de meetperiode voornamelijk erosie. Het is 
aannemelijk dat het aanvullende zand in de brekerzone extra golfenergie dissipeert. De verwachting is dat de uitbouw van de ondiepe zone richting het meer een positieve uitwerking heeft op de golfaanval op de kustlijn. Bij vergroting van het volume zou het effect groter kunnen zijn, maar ook erg tijdelijk.

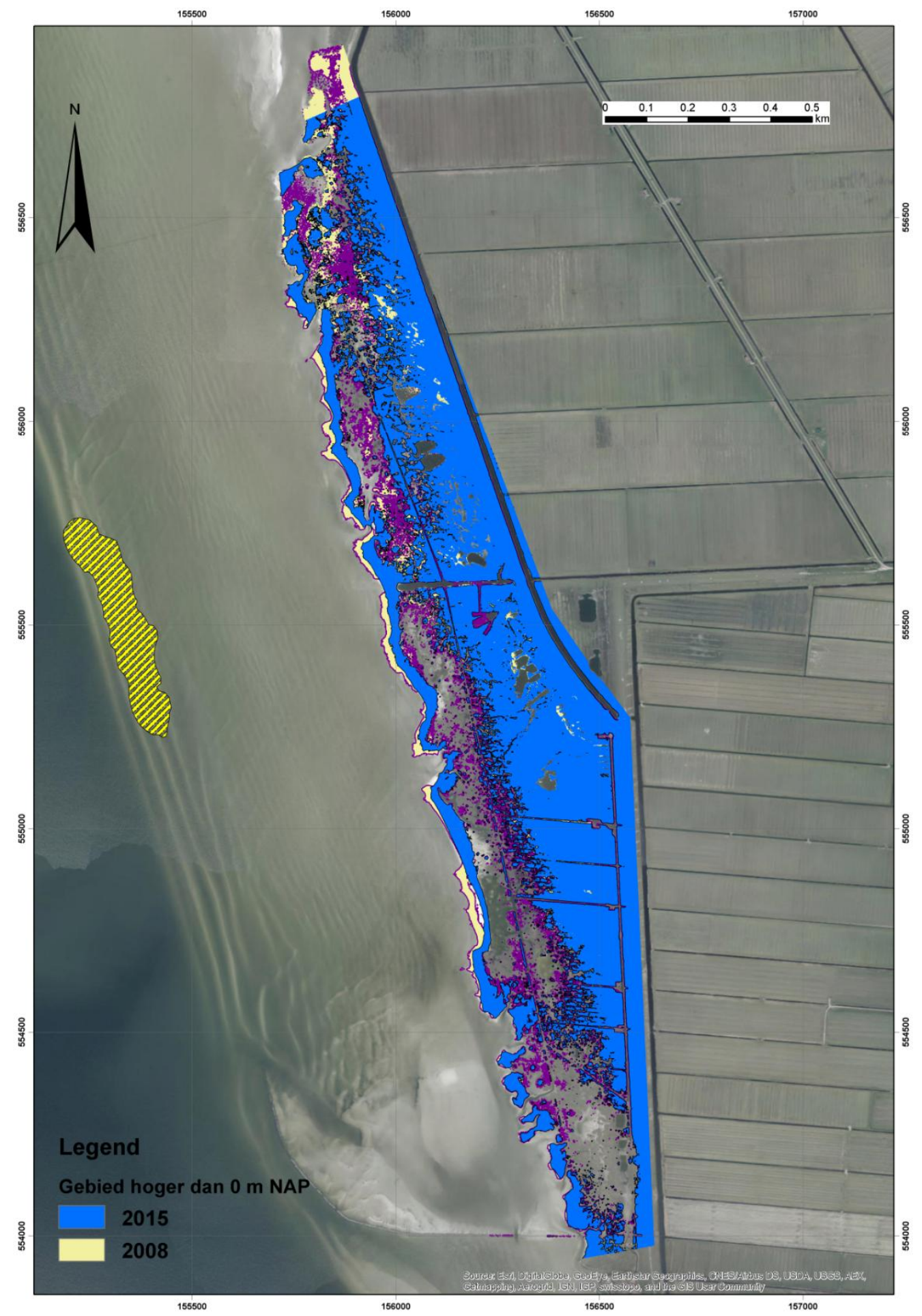

Figuur 5.3 Verschilbeelden van hoogteopnamen van de Workumerwaard. De suppletie is geel gearceerd weergegeven. Duidelijk te zien is de afslag van de kust tussen 2008 en 2015. 


\section{ALTERRA}

\subsubsection{Effecten van de palenrij}

De palenrij bestaat uit een rij palen met één paal tussenafstand. Door deze onderlinge afstand kan er nog doorstroming plaatsvinden. Deze doorstroming is zichtbaar door kleine ontgrondingskuilen tussen de palen in. De gedachte bij de palenrij was om sediment vast te houden in het gebied, aan de zuidkant van de palenrij. Aan de zuidkant is echter geen sedimentatie waargenomen. Uit waarneming van natuurbeheerders blijkt dat na de aanleg van de suppletie het fijne sediment uit de suppletie in het ondiepe kustgebied ten noorden van de palenrij is afgezet. Dit sediment was echter na een jaar weer verdwenen.

Bij het mogelijk inzetten van palenrijen kunnen de bestaande dammen helpen om meer systeembegrip te verwerven. De dam ten zuiden van de vaargeul bij Workum houdt de vooroever ten zuiden ervan op lengte. Ten noorden ervan schrijdt de vooroever terug. De kromme steenbestorting ten noorden van de vaargeul lijkt ten noorden weer een uitbouw van de vooroever tot gevolg te hebben. Dergelijke waarnemingen zouden getoetst moeten worden met modellen en systeemkennis om algemene vuistregels voor dammen langs de Friese IJsselmeerkust aan te leggen.

\subsubsection{Effecten op aquatische vegetatie}

De monitoring volgt de waterplantenbedekking op drie raaien loodrecht op de kustlijn, met per raai drie vaste punten (permanente quadraten $=P Q$ s) (Figuur 5.4). De controleraai bevindt zich ten zuiden van de zandmotor, in een deel wat waarschijnlijk nog beïnvloed wordt door de eerder aangelegde stortsteendam. De bedekkingspercentages op de controleraai (punten W7, W8 en W9) zijn over het algemeen hoger dan op de twee meetraaien (Figuren 5.5 - 5.7). Uit deze figuren blijkt ook dat er van jaar tot jaar variatie is in de bedekkingspercentages, met de laagste percentages in 2014 en 2015. Binnen het groeiseizoen worden de hoogste bedekkingspercentages in augustus waargenomen. In de monitoring zijn drie soorten onderscheiden, Schedefonteinkruid (ca. $66 \%$ ), kranswier (ca. $33 \%$ ) en draadwier (<1\%) (zie Bijlage $\mathrm{B}$ voor de uitgebreide rapportage).

De monitoring van de aquatische vegetatie laat een vergelijkbaar beeld zien als de Rijkswaterstaat MWTL monitoring: lage bedekkingspercentages die afnemen richting het open water. 


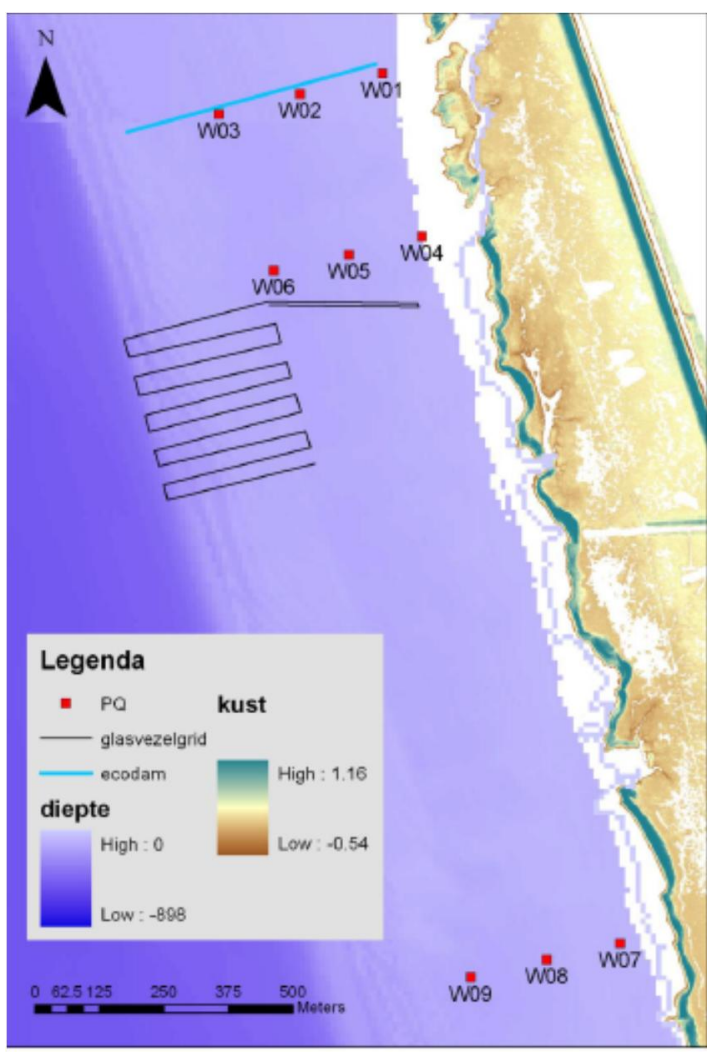

Figuur 5.4 Ligging van de meetpunten (PQs) voor de aquatische vegetatie monitoring.

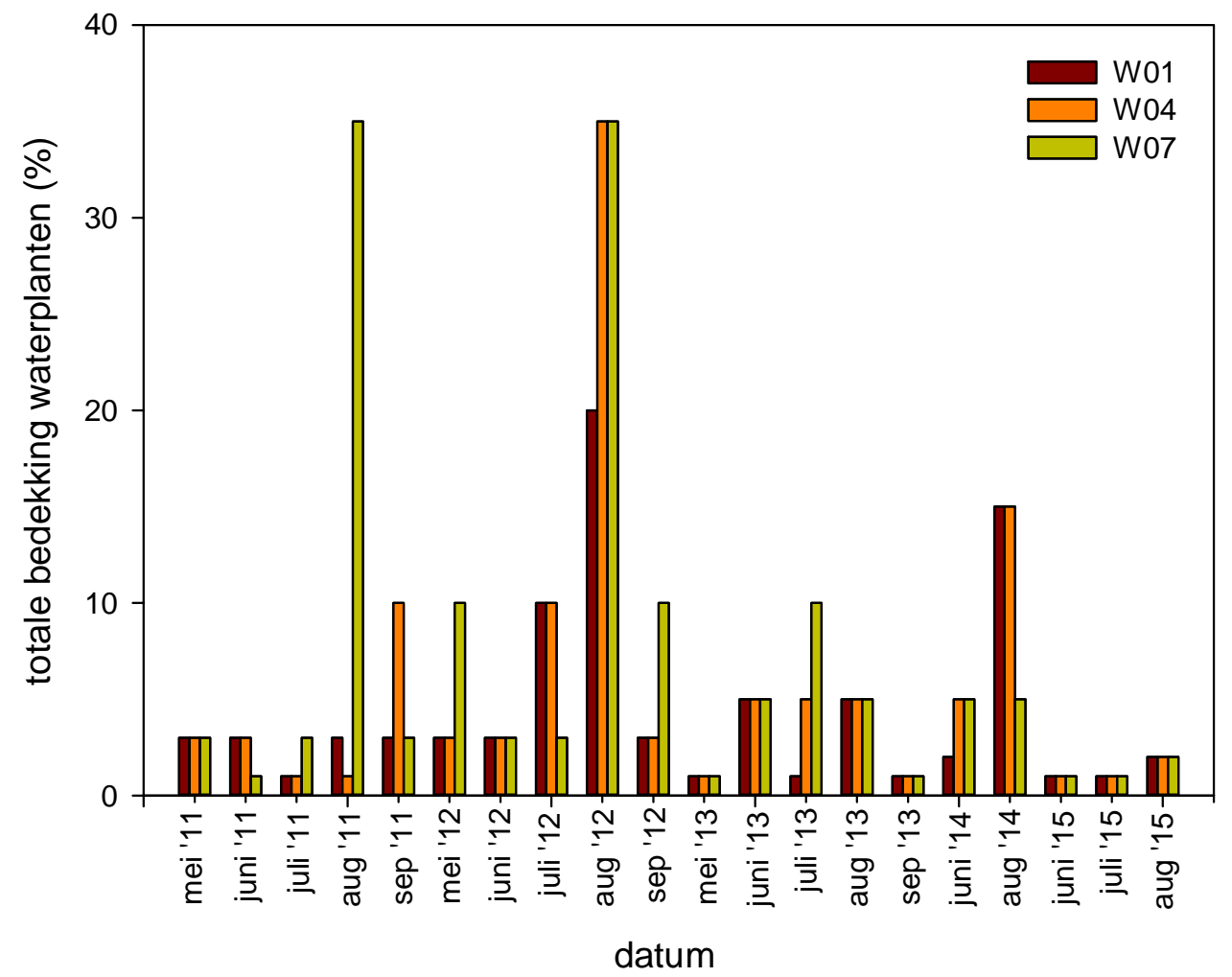

Figuur 5.5 Vegetatiebedekking \% op de PQs het dichtst langs de kust, W01 is bij palenrij, W04 is ter hoogte van zandsuppletie en $\mathrm{W} 07$ is controle raai 
$\left[\begin{array}{l}\text { ALTERRA } \\ \text { WAGENINGENUR }\end{array}\right.$

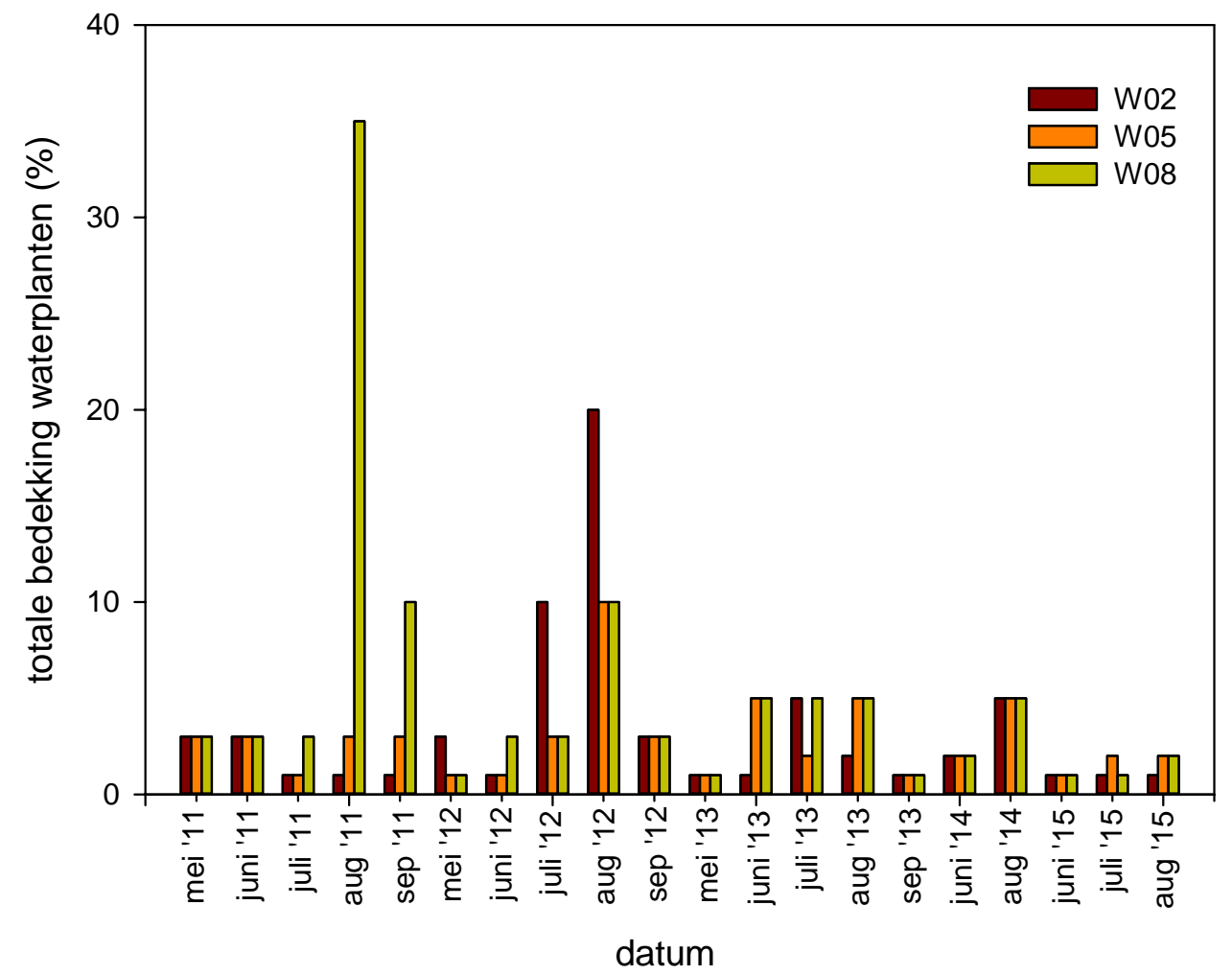

Figuur 5.6 Vegetatiebedekking \% op de PQs halverwege de raai. W02 is bij de palenrij, W05 is ter hoogte van zandsuppletie en $W 08$ is controle raai.

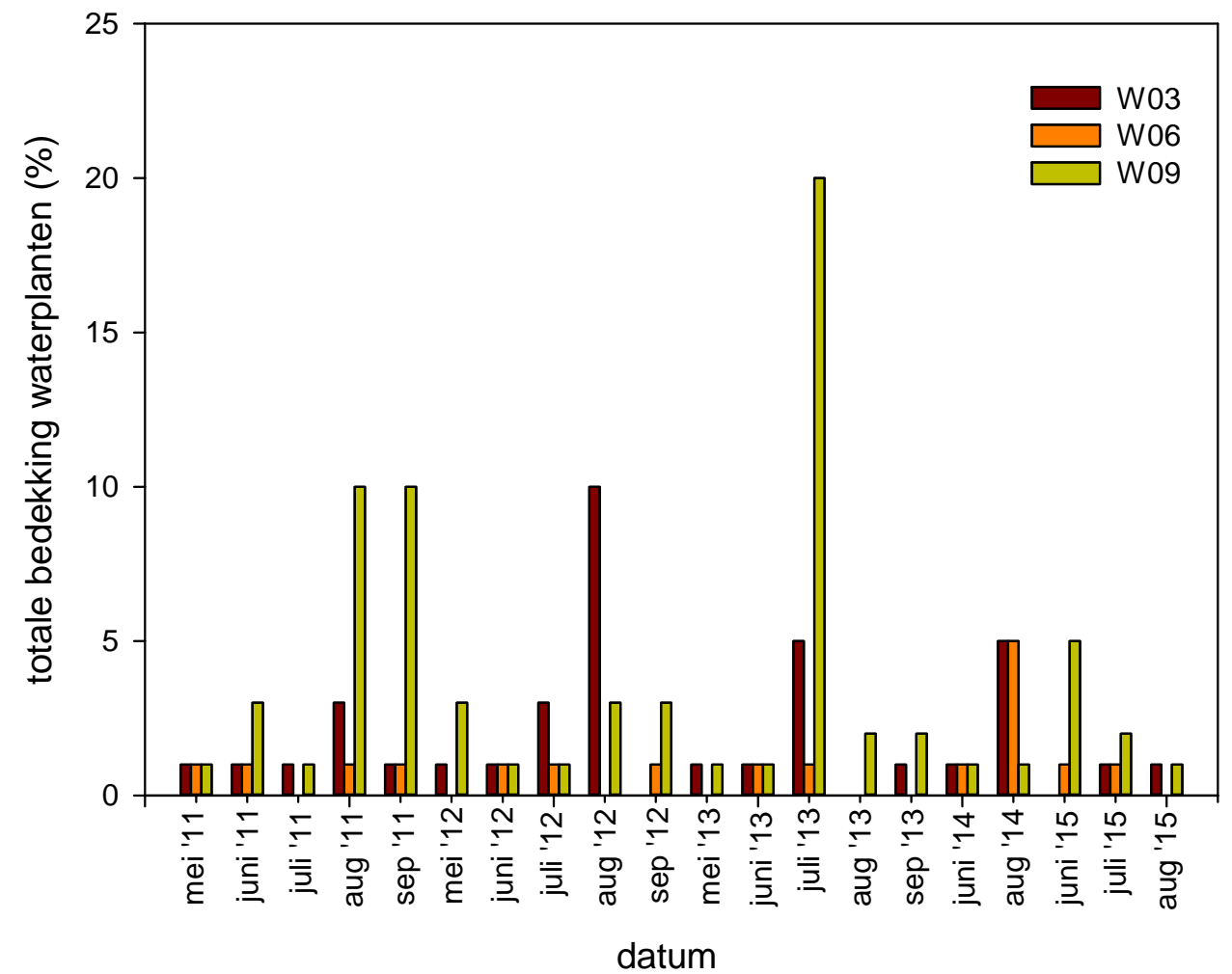

Figuur 5.7 Vegetatiebedekking \% op de PQs het meest meerwaarts. W03is bij de palenrij, W06 is ter hoogte van zandsuppletie en W09 is controle raai. 


\section{Effect van de zandsuppletie op aquatische vegetatie}

$\mathrm{Er}$ is een verschil in de tijd tussen controleraaien en meetraaien, met een lichte toename van het bedekkingspercentage op de meetraaien. Een mogelijke verklaring is dat er vanuit de zandsuppletie extra nutriënten beschikbaar zijn gekomen. Dit is niet te onderbouwen vanuit meetdata, aangezien er van het sediment geen nutriënten gehaltes gemeten zijn. De korrelgrootteverdeling is wel gemeten. Het slibgehalte (percentage $<63 \mu \mathrm{m}$ ) is niet beïnvloed door de suppletie, en is maximaal $1.3 \%$. De waterdiepte is niet significant beïnvloed door de suppletie en ook de zichtdiepte door de jaren heen vertoont geen relatie met de zandsuppletie (Kater, 2015). Een laatste mogelijke verklaring is dat de bodemschuifspanning op de meetraaien als gevolg van de zandsuppletie is afgenomen, wat een gunstig effect heeft op de vestiging en groei van waterplanten (Kater et al., 2012).

\subsubsection{Effecten op terrestrische vegetatie}

De vegetatie in de Workumer buitenwaard is gemonitord om effecten van de zandsuppletie op de terrestrische vegetatie vast te stellen. Hiervoor is van 32 PQs verdeeld over 5 raaien in 2011, 2012 en 2015 de soortensamenstelling en de structuur van de vegetatie vastgesteld. In totaal zijn 129 verschillende plantensoorten aangetroffen gedurende de totale monitoringsperiode. (zie Bijlage $\mathrm{C}$ voor de uitgebreide rapportage).

De monitoring geeft een vergelijkbaar beeld met de vegetatie opnames uit 1981 (Andeweg \& Roog, 1982). De vegetatie van de Workumer buitenwaard is heterogeen, matig soortenrijk, met een duidelijke ecologische gradiënt die wordt veroorzaakt door de hydrologische condities, sedimentatie en erosie processen, en de op plaatsen intensieve begrazing. Zilte invloed is nog steeds te herkennen in de aanwezigheid van Ruwe bies en Zeebies. De soortensamenstelling op de PQs in 2011 is gebruikt om met Twinspan zes verschillende vegetatietypen te classificeren. De resultaten in 2012 en 2015 zijn hiermee vergeleken.

Tussen 2011 en 2015 is de vegetatie significant veranderd, maar het is niet waarschijnlijk dat dit een gevolg is van zandsuppletie. De veranderingen in de vegetatie zelf (soortensamenstelling en abundantie) duiden op een afname van de landhoogte en een toename van oppervlakte kale grond. Voor de vegetatie op de schelpenbanken is een afname van de oppervlakte kale grond geconstateerd. De veranderingen in hoogteligging zijn verwaarloosbaar of wijzen op een afname van de hoogte, vooral meer landinwaarts. Het gebied wordt begraasd en dit heeft effecten op de vegetatie. Begrazing is wellicht gedeeltelijk verantwoordelijk voor de waargenomen veranderingen in de vegetatie, maar door het ontbreken van kwantitatieve gegevens over begrazing is het niet vast te stellen in welke mate. Hierbij moet worden gerealiseerd dat het gebied al decennia wordt begraasd, daardoor is het niet duidelijk wat de autonome ontwikkeling is van de vegetatie, en welk deel door begrazing wordt veroorzaakt.

Figuur 5.8 geeft de landhoogte (z gemeten met dGPS) van de PQs langs de vijf transecten. De afname van de landhoogte van de PQs die meer naar landinwaarts liggen duidt op erosieprocessen die waarschijnlijk door anoxia in de wortelzone zijn veroorzaakt, in combinatie met hoge graasdruk door vee. Dit kan gezien worden als een negatieve ontwikkeling, omdat dit grote delen van de buitenwaard kwetsbaar maakt voor verdere erosie. 


\section{$\underbrace{\frac{A L T E R R A}{\text { WAGEINGENUR }}}_{-3}$}

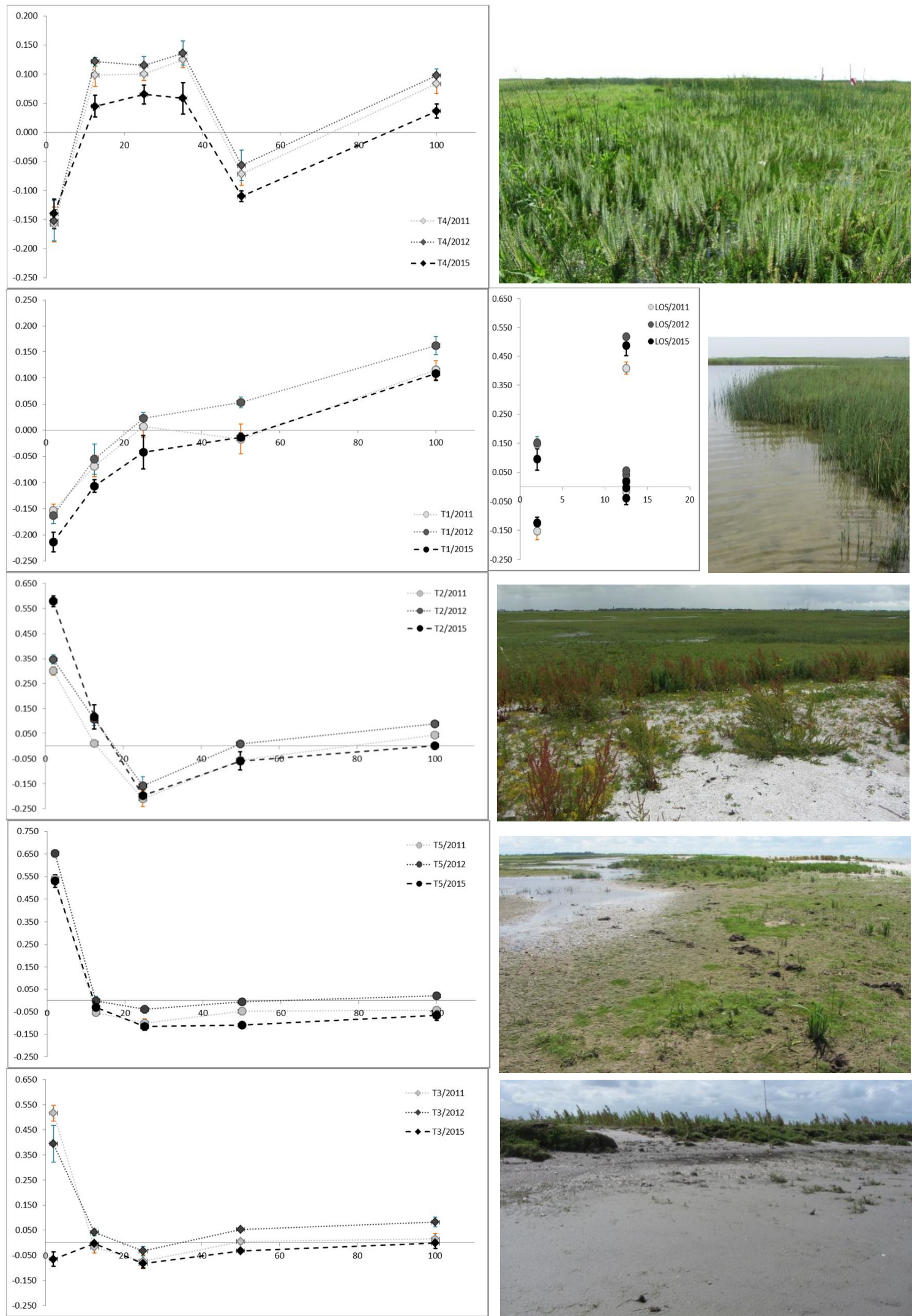

Figuur 5.8 De transect profielen samen met een foto impressie van de vegetatie. De $x$-as is de afstand vanaf de oeverlijn, de $y$-as de hoogte in $m$ NAP (gemiddelde van 5 metingen $\pm 1 S D$. Transect $4=$ controle, moeras; transect 1 = effect, dichtbij de dam, moeras; transect 2 = effect, dichtbij de dam, schelpenbank; transect 5 = effect, schelpenbank; transect 3 = controle, schelpenbank. Overgenomen uit Eco-recover (2015). 
De afname in de landhoogte gemeten met de dGPS is $\sim 5 \mathrm{~cm}$. Dit verschil is te klein om te meten met LIDAR. De verschillen van de schelpenbank/strandwal komen wel overeen tussen de dGPS en LIDAR metingen. Op het meest zuidelijke transect heeft de schelpbank zich tussen 2012 en 2015 enkele meters landinwaarts verplaatst. Dit is in overeenstemming met Kooistra (1980) die beschrijft dat schelpbanken door golfwerking geleidelijk de zandplaat op schuiven.

De veranderingen in de vegetatie kunnen niet gerelateerd worden aan de zandsuppletie. De veranderingen moeten daarom gezien worden als een autonome ontwikkeling in het gebied, waarbij graas door vee en ganzen een belangrijke stuurfactor is. Door het landgebruik te veranderen in de buitenwaarden kunnen op grote schaal en langere termijn worden bereikt (Menke en Lenselink, 1997). Een zandmotor maakt de gebieden niet meer ecologisch robuust.

\subsection{Resultaten pilot zandmotor Oudemirdum}

5.3.1 Hoe verspreidt het zand zich en hoe snel beweegt het zand?

Sinds de aanleg vlakt de suppletie geleidelijk af en verschuift de suppletie naar het oosten (Figuur 5., 5.10 en Bijlage A). De suppletie vertoont minder grote dynamiek dan de suppletie bij Workum. De vorm van de suppletie blijft duidelijk zichtbaar als een anomalie in de dieptemetingen. Het lijkt er op dat het zand bij een suppletie in het ondiepe gebied beter in het systeem blijft en minder snel verdeeld wordt. Hiermee blijft het golfdissiperende effect van de zandmotor langer behouden.
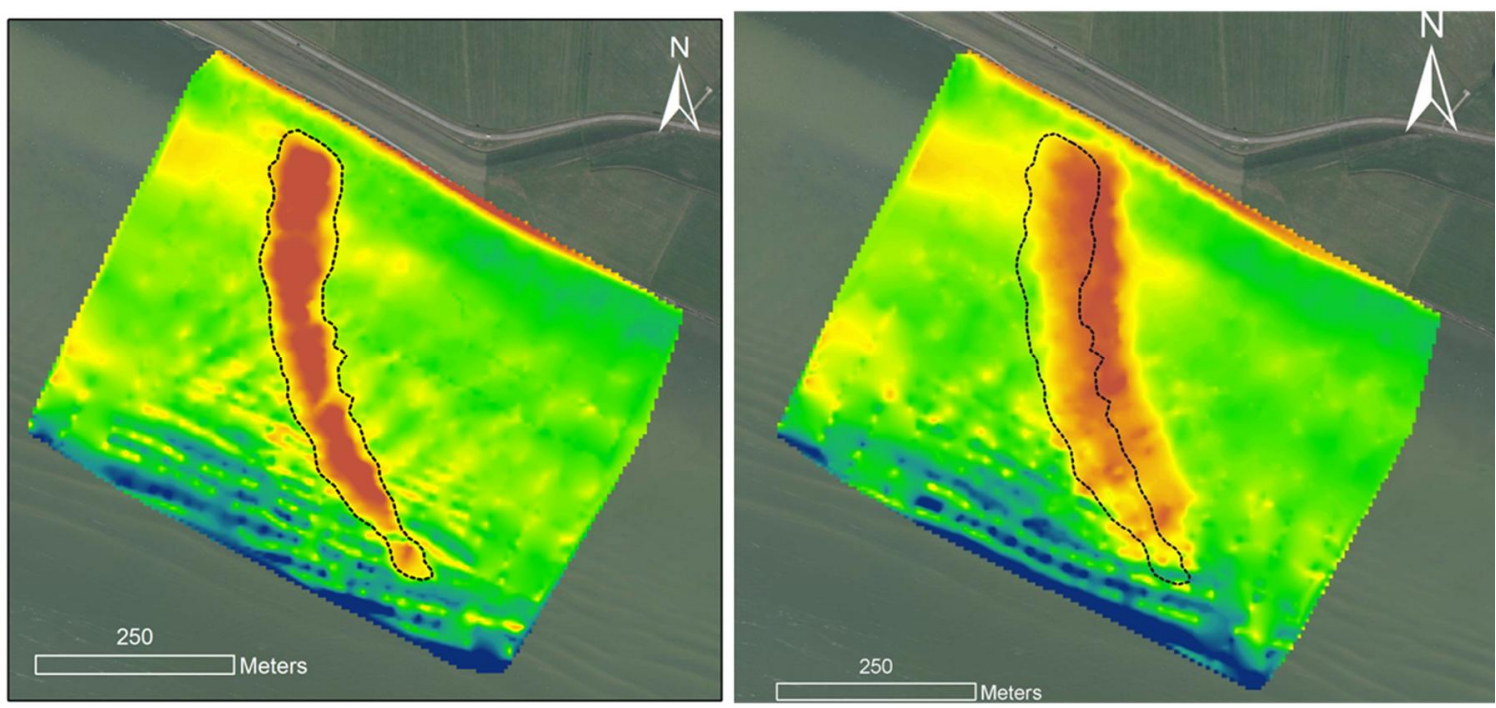

Figuur 5.9 Hoogtemodel van de suppletie bij Oudemirdum. Links) vlak na de aanleg (T1; 2013).Rechts) tweeëneenhalf jaar na aanleg $(T 4 ; 2015)$ 


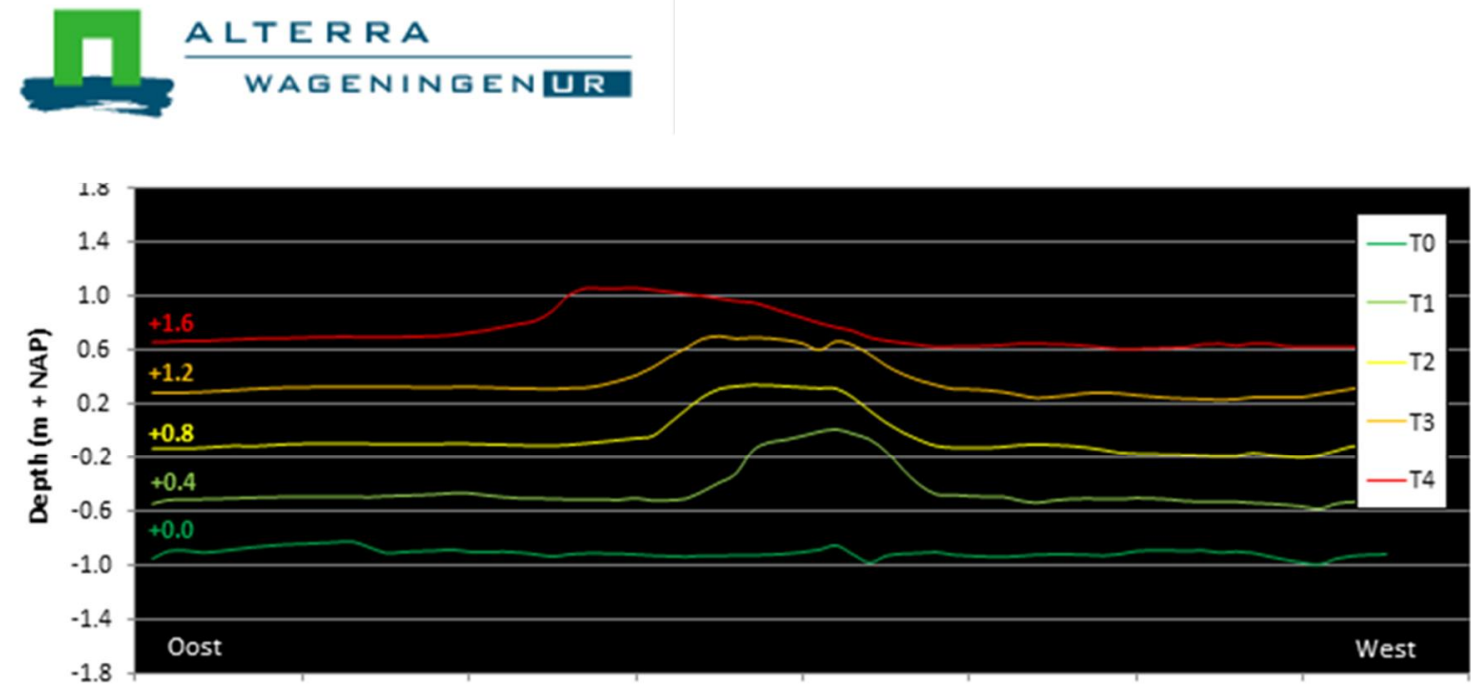

Figuur $5.10 \quad$ Ontwikkeling van de suppletie bij Oudemirdum in vijf tijdstappen in een oost - west profiel dwars over de suppletie. Tijdstap T0 is de uitgangssituatie, tijdstap T1 is de tijdstap na de aanleg van de suppletie. De daarop volgende tijdstappen laten de evolutie van de zandmotor zien die afvlakt en zich naar het oosten verplaatst. leder profiel is $40 \mathrm{~cm}$ omhoog geplaatst om de veranderingen te illustreren. Voor de locatie van het profiel wordt verwezen naar Bijlage $A$.

\subsubsection{Effect op aquatische ecologie}

De monitoring bij Oudemirdum laat een vergelijkbaar beeld zien vergeleken met Workum, met afnemende bedekkingspercentages richting het open water (Figuren 5.11 - 5.13; en bijlage B). Er is geen duidelijk verschil tussen de raaien voor (2012) en na aanleg (2013) van de zandmotor. De PQs het dichtst bij de kust (Figuur 5.11) laten geen systematisch verschil zien. De PQ's in het midden van elk transect (Figuur 5.12) en de PQ's het meest meerwaarts (Figuur 5.13) verschillen wel. In 2013 hebben deze PQ's een hoger bedekkingspercentage ten westen van en op de zandsuppletie, en een lager bedekkingspercentage ten oosten van de zandsuppletie, vergeleken met 2012.

De bedekkingspercentages liggen hoger dan bij Workum, tussen $25 \%$ en $50 \%$ met incidentele uitschieters tot $90 \%$. In 2014 is niet gemonitord, en in 2015 alleen in juli. De bedekkingspercentages in 2015 zijn beduidend lager dan in 2012 en 2013. De soortensamenstelling bij Oudemirdum wordt gedomineerd door kranswier.

Een voor de hand liggende verklaring voor het verschil tussen Workum en Oudemirdum is het verschil in golfwerking. Workum wordt meer blootgesteld aan de heersende zuidwestenwind dan Oudemirdum, dat verklaart het verschil in bedekkingspercentage en het verschil in soorten. Een lagere bodemschuifspanning zou hiervoor de mechanistische verklaring kunnen zijn, maar dit is niet verder onderzocht voor Oudemirdum. 


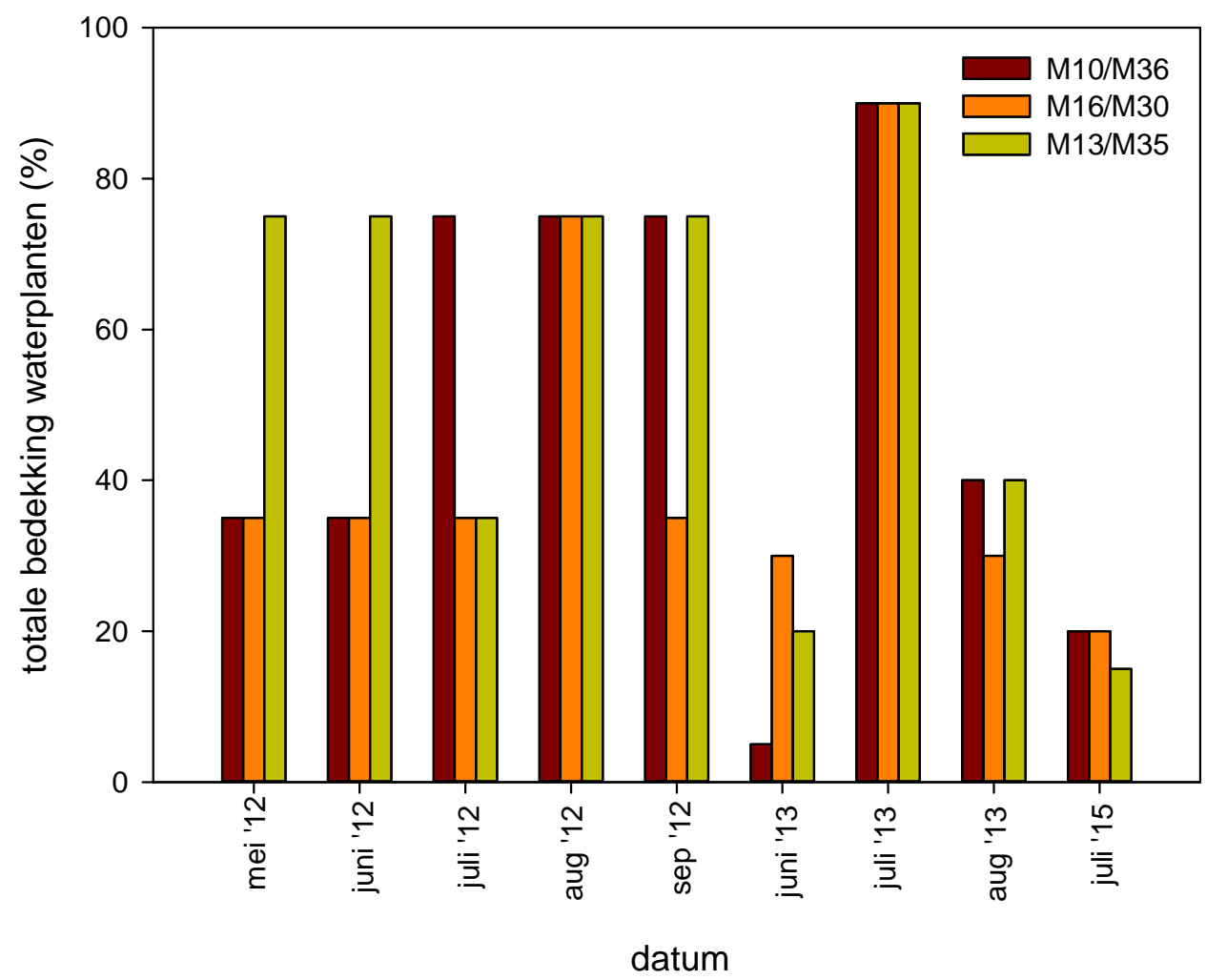

Figuur 5.11 Vegetatiebedekking \% op de PQs het dichtst langs de kust, M10/M36 is ten westen van de suppletie, M16/M30 is ter hoogte van zandsuppletie en M13/M35 is ten oosten van de suppletie.

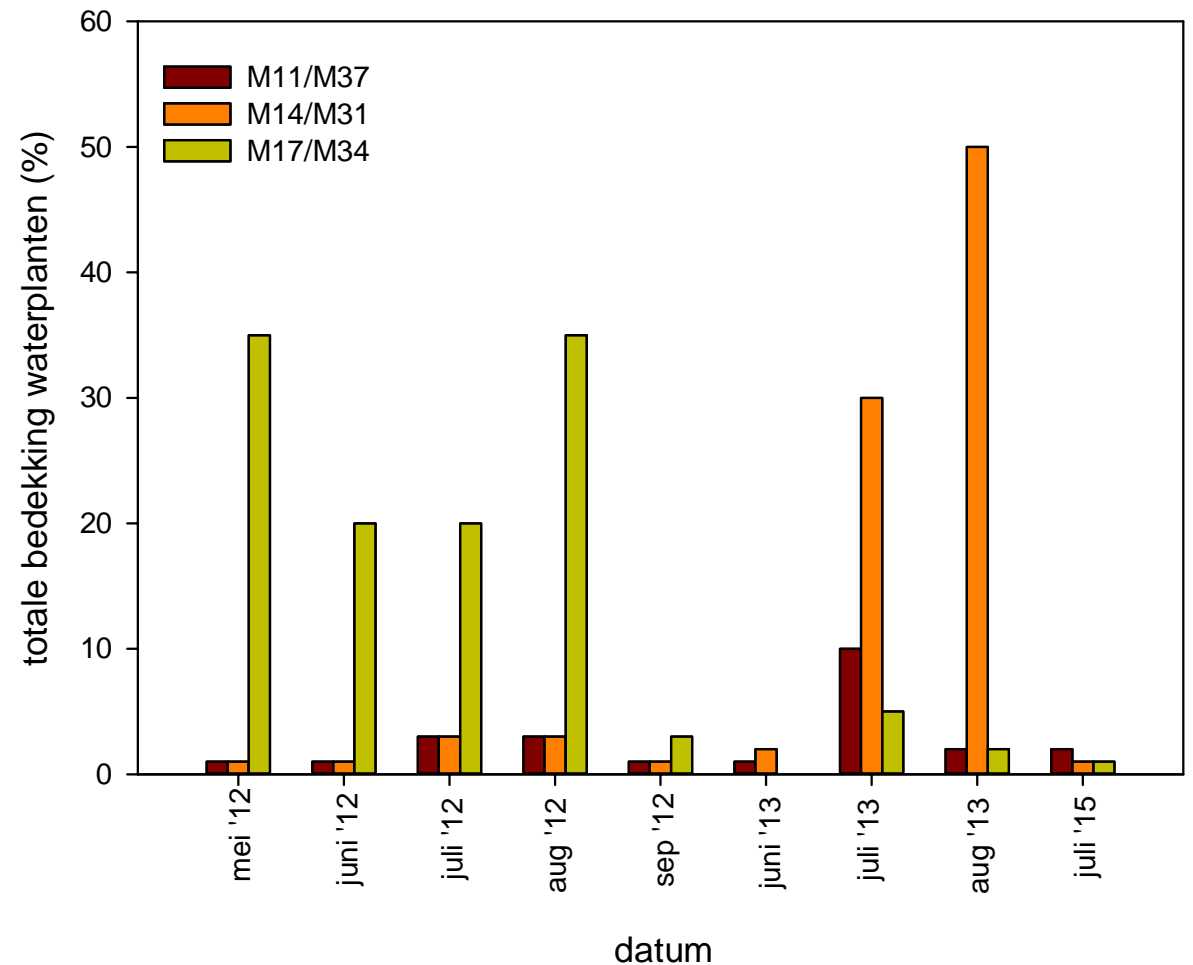

Figuur 5.12 Vegetatiebedekking \% op de PQs halverwege het transect, M11/M37 is ten westen van de suppletie, M14/M31 is ter hoogte van zandsuppletie en M17/M34 is ten oosten van de suppletie. 
$\left[\begin{array}{l}\text { ALTERRA } \\ \text { WAGENINGENUR }\end{array}\right.$

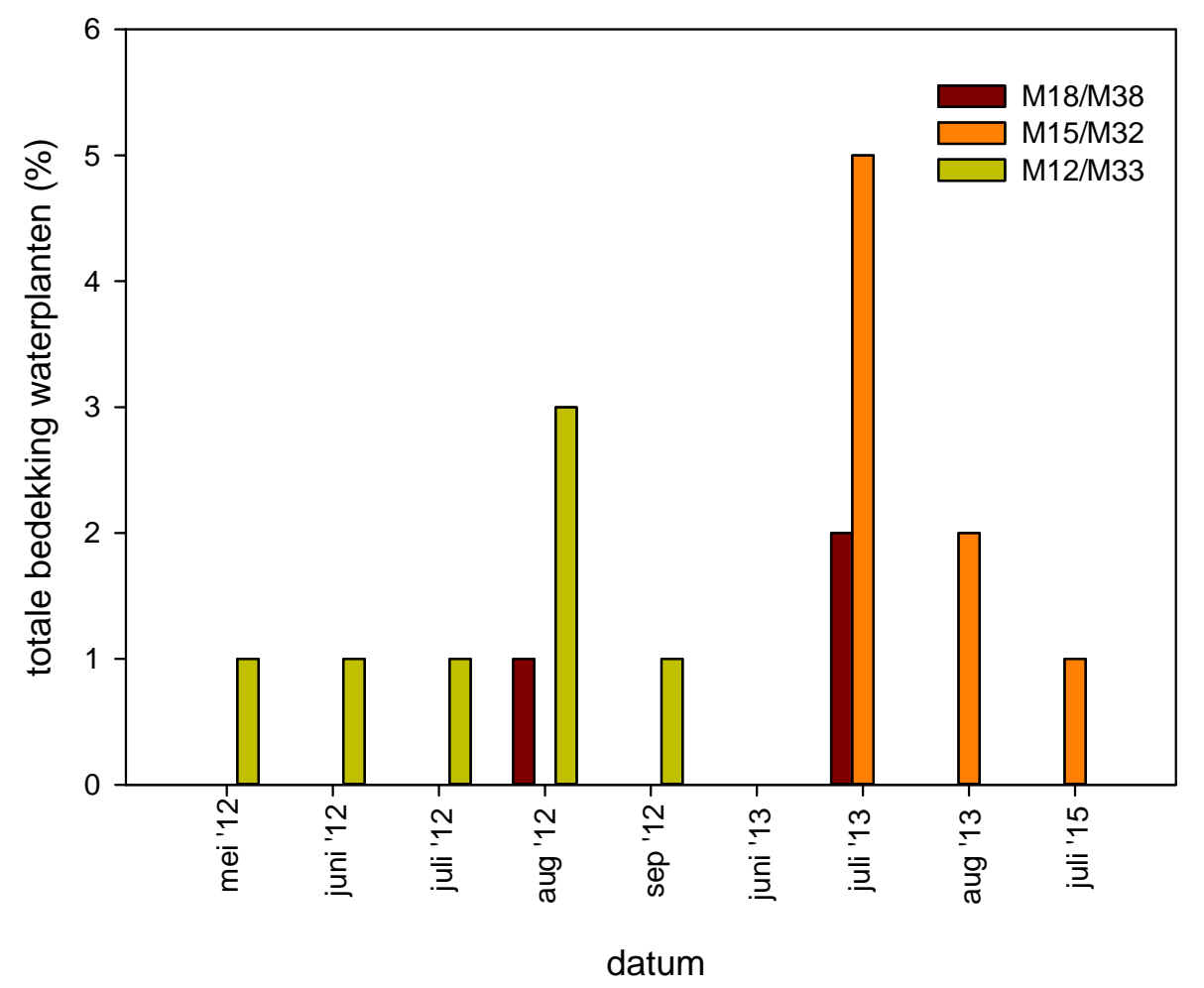

Figuur 5.13 Vegetatiebedekking \% op de PQs het meest meerwaarts, M18/M38 is ten westen van de suppletie, M15/M32 is ter hoogte van zandsuppletie en M12/M33 is ten oosten van de suppletie. 


\section{Discussie en conclusies}

\subsection{Geleerde lessen}

De Building with Nature experimenten en de daarmee gepaard gaande monitoring hebben bestaande kennis of vermoedens bevestigd en nieuwe kennis opgeleverd over: 1) de morfologie van de Friese IJsselmeerkust, 2) hoe de zandmotoren bij Workum en Oudemirdum functioneren en 3) over het gedrag van zandmotoren, palenrijen en eilanden voor de kust. Deze paragraaf gaat op ieder van deze elementen in met het doel om lessen te trekken voor een eventuele opschaling.

\subsubsection{Het morfologische systeem van de Friese IJsselmeerkust}

Zandtransport en daarmee gepaard gaande processen van erosie en sedimentatie zijn de morfologische motor voor kustontwikkeling. De drijvende kracht is de energie van wind en golven, die het zand noordwaarts stuurt aan de westkust en oostwaarts aan de zuidkust. Individuele stormen kunnen tot significante veranderingen leiden. De westkust en zuidkust zijn verschillend.

De zuidkust is niet onderbroken door vaargeulen en het zandtransport loopt daardoor relatief onbeïnvloed door infrastructuur van Stavoren tot Lemmer.

De westkust is complexer, want daar onderbreken vaargeulen van Hindelopen, Workum en Makkum het noordwaartse zandtransport waardoor er diverse subsystemen ontstaan (zie Figuur 2.5). leder subsysteem bestaat 'bovenstrooms' (zuidelijk) uit een zone waar erosie (van zandplaten voor de kust en/of de kust zelf) domineert en een 'benedenstroomse' (noordelijke) sedimentatiezone. Deze zones zijn goed herkenbaar op luchtfoto's. Metingen bij Workum laten verrassend grote erosie van de buitenwaarden na storm zien dat tot significant landverlies (plaatselijk 30 meter binnen een paar maanden) leidt.

Doordat het IJsselmeerpeil relatief stabiel is, vindt er continue golfaanslag plaats op één beperkte zone van de oevers. Dit is de oorzaak van oeverafslag en het ontstaan van kleine klifjes. Zelfs in de sedimentatiezones vindt zo afslag plaats van stranden (zie de stranden van Hindeloopen, It Soal bij Workum en Makkum), waardoor stranden wegslaan en de lange ondiepe plateaus voor de stranden nog ondieper worden dan ze al zijn. Dit heeft op haar beurt weer gevolgen voor bv rietontwikkeling (deze wordt door klifjes beperkt) en voor de waterkwaliteit. In rustige zones kan bij kalm weer blauwalgbloei ontstaan in de zomer.

\subsubsection{Conclusies pilots zandmotor Workum en Oudemirdum}

\section{Hoe verspreidt het zand zich en hoe snel beweegt het zand?}

Uit de suppletie bij Workum blijkt dat het zand langs de westkust in de dynamische zone met kustparallelle zandruggen zich snel noordwaarts verspreid. Binnen enkele seizoenen is het zand opgenomen in het systeem en niet meer traceerbaar. Waarschijnlijk bouwt de ondiepe zone meerwaarts uit. Langs deze westkust is de transportrichting noordwaarts.

De zandmotor bij Oudemirdum leert dat er minder zandtransport plaatsvindt in de ondiepe zone landwaarts van de dynamische zandruggen. Langs de zuidkust is die verplaatsing naar het oosten. Dit betekent dat zandsuppleties in de ondiepe zone langer effect hebben, bijvoorbeeld als golfbreker. Zandsuppleties tegen de rand van de ondiepe zone aan hebben minder lang effect en mogelijk verspreid het zand zelfs richting IJsselmeer. 


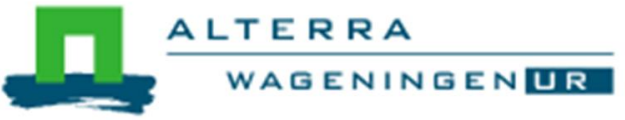

\section{Welke weersomstandigheden domineren veranderingen?}

Stormen hebben grote effecten op de morfologie. Dit blijkt bijvoorbeeld uit de observatie dat de vaargeul bij Workum na een noord(west)erstorm aanzienlijk kan zijn verzand. Zonder stormen zouden de kustparallelle ruggen waarschijnlijk niet bestaan omdat er veel golfenergie voor nodig is. Uit de glasvezelmetingen komt naar voren dat de ligging van de parallelle zandruggen geleidelijk in de tijd verandert. Morfologische veranderingen tijdens individuele stormen zijn helaas niet gemeten. Het lijkt er echter op dat bij het grootste gedeelte van het zandtransport gemiddelde weerscondities waarschijnlijk de overhand hebben. Dit wordt ook gesuggereerd in modelstudies (Folmer et al., 2010). Voor de dynamische zone met kustparallelle ruggen sturen stormen de morfologische veranderingen.

\section{Wat is het effect van de zandmotor op de kust?}

De resultaten laten zien dat het effect van de zandmotor op de kust niet waarneembaar is. De hoogte van de Workumer buitenwaard is op twee manieren gemeten, met dGPS ter hoogte van de 32 terrestrische vegetatie PQs en met LIDAR metingen. Uit de dGPS metingen volgt een lichte daling van de landhoogte, in de orde grootte van centimeters. De LIDAR metingen zijn vooral geschikt om het verloop van de kustlijn en de strandwal te volgen. Tussen 2011 en 2015 is de kustlijn bij Workum lokaal ca. 30 meter landinwaarts verplaatst. Gekoppeld aan de waarneming dat het zand van de zandmotor onder water niet landwaarts is verplaatst, maar parallel aan de kust, kan geconcludeerd worden dat er geen effect van de zandmotor op de kust is geweest. In de luwte van de zandmotor zijn ook geen effecten waarneembaar. De erosie moet gezien worden als een autonoom proces.

\section{Wat zijn de effecten van de zandmotor op de ecologie zowel onder als boven water?}

De effecten van de zandmotor op de onderwater vegetatie zijn beperkt. In de pilot Workum is er een lichte toename van bedekkingspercentage na aanleg van de zandmotor, wat verklaard zou kunnen worden met een afgenomen bodemschuifspanning (gemodelleerd) als effect van de zandmotor. De absolute verschillen zijn echter niet groot. De resultaten van de pilot bij Oudemirdum geven een vergelijkbaar beeld van slechts beperkt tot geen duidelijk effect van de zandmotor op de onderwater vegetatie.

De terrestrische vegetatie monitoring heeft laten zien dat er duidelijk autonome ontwikkelingen zijn in de tijd, maar dat deze geen verband hebben met de zandmotor. Er is dus geen positief of negatief effect van de zandmotor op de terrestrische vegetatie, dus geen ecologische meerwaarde van een zandmotor.

\subsubsection{Zandmotoren, palenrijen en lage eilanden voor de kust}

Fysieke metingen en modelstudies hebben de volgende lessen opgeleverd over een aantal mogelijke Building with Nature geïnspireerde maatregelen.

Uit de zandmotor proeven blijkt dat:

- Zand inbrengen in het systeem is een relatief goedkope adaptatie maatregel bij verandering van het peilbeheer. De monitoringsgegevens laten tot en met 2015 zien dat het gesuppleerde zand in Workum en Oudemirdum nog aanwezig is in het systeem en dat er flinke dynamiek en sedimentverplaatsing in het gebied aanwezig is. Het zand blijft onder de waterlijn, en er vindt geen ophoging van de bestaande buitenwaarden plaats.

- Bij suppletie in het dynamische gedeelte van de vooroever aan de rand van het IJsselmeer (zoals bij Workum) wordt het zand snel verspreid en wordt nauwelijks extra veiligheid gecreëerd. Het in stand houden van de ondiepe vooroever is echter wel van belang, omdat op de rand ervan de grootste golven breken. In de luwte, 
landwaarts van de dynamische zone (zoals bij Oudemirdum) blijft het verspoelde zand langer liggen.

- De monitoringsresultaten tot nu toe tonen dat de Oudemirdum zandmotor (dicht bij de kust in een haakvorm) langer haar vorm en functie behoudt dan de Workumerwaard zandmotor. Geen van beiden hebben gezorgd voor aanzanding aan de kust, wat wel de gewenst was.

- De omvang van het volume en de schaal van beide zandmotor experimenten is klein; zo klein dat geen significante effecten op ecologie zijn gemeten. Het ligt in de rede te verwachten dat bij opschaling deze effecten wel gaan optreden. In Lauwaars en Platteeuw (1999) zijn bijvoorbeeld bij een aantal ingrepen duidelijke ecologische effecten gemeten.

- Verspoelingen van zand en aanzandingen rond de beide zandmotoren - zo tonen metingen aan - zijn lokaal van aard. De volumes van de aangebrachte suppleties zijn even groot als modelramingen van het totale jaarlijkse langstransport langs de westkust (zie paragraaf 2.1). Op de lange termijn mogen dan ook effecten op het gebied van dichtslibben van vaargeulen noordwaarts van ingrepen verwacht worden. Om deze reden lijken grootschalige suppleties langs de Friese westkust op de langere termijn onverstandig. Ingrepen langs deze kust met zand zijn niet gewenst. Daarom moet voor deze kust meer gedacht worden aan ingrepen in de vorm van beschermde eilanden of veranderingen in vegetatie/begrazing.

- De zandsuppleties leiden tot dissipatie van golfenergie. Ook de zandruggen op de rand van de vooroever dragen bij aan de golfdissipatie. Of de extra dissipatie daadwerkelijk leidt tot afname van golfenergie op de kust in de luwte ervan is niet vastgesteld op basis van de metingen. Er is geen zichtbaar effect op de kust van de Workumerwaard sinds de aanleg van de zandmotor. In de onderwatervegetatie is ook geen effect te zien. Hieruit kan geconcludeerd worden dat de extra zandruggen geen remmend effect hebben gehad op de eroderende werking van golfaanval. Autonome processen van erosie, gekoppeld aan de vegetatiestructuur en type beheer, hebben waarschijnlijk een grotere rol gespeeld dan de golfdissiperende werking van de zandsuppletie.

- Zandsuppleties onder water (dynamische suppletie) hebben geen significant aantoonbaar positief of negatief effect op ecologie. Bij beide pilot locaties zijn er geen significant aantoonbare positieve of negatieve effecten waargenomen op de vegetatie onder water en boven water.

De bovenstaande conclusies moeten in het licht gezien worden van het feit dat de twee zandmotoren relatief klein waren. Bij grootschaliger ingrepen is de verwachting dat er wel waarneembare effecten zullen zijn op golfdissipatie of op de onderwatervegetatie. Echter, in de dynamische zone is iedere zandige ingreep snel verdwenen en verliest zijn effect. Dit blijkt ook uit de effecten van de zandmotor bij de Workumerwaard uit 1992 (Lauwaars en Platteeuw, 1999). Een belangrijk inzicht is dat langs de zuidkust grootschalige ingrepen die gebruikmaken van zand interessant zijn, omdat het om een aaneengesloten systeem gaat met voornamelijk een natuuropgave. Langs de westkust zijn grote ingrepen met zand ingewikkeld omdat deze kust is verdeeld in compartimenten, en veel gebruiksfuncties heeft, zoals watersport, natuur en recreatie. De vaargeulen zullen een verhoogd baggerbezwaar krijgen. 


\section{$\underbrace{}_{-3} \frac{\text { ALTERRA }}{\text { WAGENINGENUR }}$}

Modelstudies van de kust voor Hindeloopen tonen aan dat de aanleg van golfremmende werken (zoals geotubes, biezenmatten of palenrijen) die de kracht van de golfaanval op de kust verminderen, een positief effect hebben op vermindering van afslag van het strand door golven. Er ontstaan luwtezones voor vogels, vegetatie en vis. Dit verhoogt de ecologische kwaliteit van het gebied en de natuurwaarde.

\subsection{Opschaling}

Building with Nature is meer dan alleen een technische aanpak om concrete waterproblemen op te lossen. Dat Building with Nature inspireert blijkt uit landschapsontwerpen (Strootman Landschapsarchitecten, 2014 ${ }^{1}$; LINT landscape architecture \& Deltares $(2014)^{2}$ ) en bijdragen van natuur en milieu organisaties (Veerkrachtige IJsselmeerkust ${ }^{3}$, It Fryske $\mathrm{Gea}^{45}$ ). Building with Nature maatregelen scheppen de mogelijkheid om meerdere functies te combineren en om het landschap te verfraaien. Daarom kreeg het in het 'Atelier Fryslân ${ }^{6}$ visie proces een prominente plaats. Mede hierdoor zijn de proeven, die in dit rapport beschreven worden, geïnitieerd.

Opschaling van Building with Nature maatregelen zal dus van veel meer motieven afhangen dan puur hydro-morfologische. Hierbij horen de volgende algemene ontwerpprincipes:

1. Building with Nature ontwerpen gaan uit van een op natuurlijke processen geïnspireerde en samen met belanghebbenden ontwikkelde aanpak. Voorstellen voor maatregelen spelen in op mogelijkheden en kansen die zich voordoen in het natuurlijke en in het maatschappelijk/bestuurlijke systeem. Om ideeën te ontwikkelen is kennis van dat systeem nodig, maar er wordt niet gewacht tot het systeem geheel gekend wordt. Dat is niet mogelijk door de dynamiek en daarmee gepaard gaande onzekerheden van het systeem. Door het uitvoeren van maatregelen en het zorgvuldig monitoren van fysieke als governance aspecten groeit kennis van het systeem, oftewel "learning by doing". Hiervoor is het essentieel om eerdere ingrepen in een gebied, en effecten daarvan, goed te analyseren.

2. Building with Nature ontwerpen - zoals de twee zandmotoren - zijn flexibel en dynamisch en dat betekent dat maatregelen gemakkelijk aanpasbaar zijn in geval van veranderende ontwerpeisen of externe omstandigheden

3. Building with Nature ontwerpprocessen worden in interactie met belanghebbenden ondernomen. Dit vraagt om interactie tussen expertkennis en lokale en ervaringskennis. Het eigenaarschap van BwN infrastructuur wordt gedeeld.

Op basis van deze algemene BwN ontwerpprincipes en de inzichten die uit deze studie zijn voortgekomen, worden in tabel 6.1 Building with Nature maatregelen geïnventariseerd die kansrijk zijn om de Friese IJsselmeerkust duurzaam te beschermen. Aanbevolen wordt deze maatregelen in de MIRT-verkenning mee te nemen.

\footnotetext{
${ }^{1}$ Strootman Landschapsarchitecten (2014): Kwaliteitskader IJsselmeergebied. College van Rijksadviseurs, Rijksadviseur voor Landschap en Water.

${ }^{2}$ LINT landscape architecture \& Deltares (2014) Sedimental Scenes, Ontwerpend onderzoek Friese IJsselmeerkust.

${ }^{3}$ Brochure Stichting het Blauwe Hart

${ }^{4}$ Presentatie Chris Bakker (2014) Kansen voor Building with Nature langs Friese IJsselmeerkust

${ }^{5}$ ACT project (2014) Kansen voor de Makkummer kust. Een fysische en sociaal-economische analyse. Stichting het Blauwe Hart.

${ }^{6}$ http://www. atelierfryslan.nl/
} 
Tabel 6.1: Opschaling van Building with Nature maatregelen langs de Friese IJsselmeerkust

\begin{tabular}{|c|c|c|}
\hline Opgaven & Building with Nature maatregel & Opmerkingen \\
\hline $\begin{array}{l}\text { Duurzame } \\
\text { kustbescherming in } \\
\text { combinatie met } \\
\text { dynamische natuur }\end{array}$ & $\begin{array}{l}\text { Zandmotor/dynamisch zandeiland } \\
\text { ter hoogte van het Vrouwenzand } \\
\text { met als doel om de Friese zuidkust } \\
\text { te voeden op de schaal van } \\
\text { tientallen jaren en als dynamisch } \\
\text { eiland om natuurwaarden in stand } \\
\text { te houden. }\end{array}$ & $\begin{array}{l}\text { Dit vraagt afstemming met het } \\
\text { voornemen om grof zand langs de } \\
\text { zuidkust te winnen en om } \\
\text { afdekkende lagen van de winning } \\
\text { en vrijkomend slib in het systeem } \\
\text { te brengen. } \\
\text { Onderzoek is nodig naar locaties } \\
\text { en mogelijke effecten op } \\
\text { zandtransport en ecologie. }\end{array}$ \\
\hline $\begin{array}{l}\text { Tegengaan van } \\
\text { erosie } \\
\text { buitenwaarden }\end{array}$ & 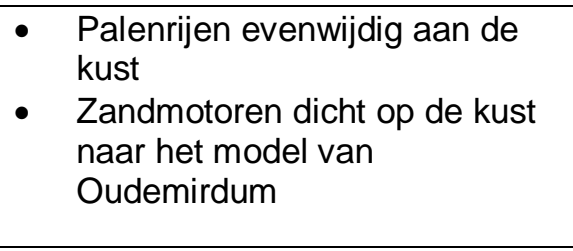 & $\begin{array}{l}\text { Doel is om de golfenergie te } \\
\text { verminderen. } \\
\text { Zandinbreng aan de westkust zal } \\
\text { potentieel het baggerbezwaar van } \\
\text { de vaargeulen laten toenemen. } \\
\text { Zorgvuldige locatiekeuze is nodig. }\end{array}$ \\
\hline $\begin{array}{l}\text { Tegengaan van } \\
\text { erosie stranden } \\
\text { Molkwerum, } \\
\text { Hindeloopen, It Soal, } \\
\text { Makkum, Lemmer, } \\
\text { Oudemirdum. }\end{array}$ & $\begin{array}{l}\text { Lage eilanden van biezenmatten of } \\
\text { palenrijen op plekken met } \\
\text { voldoende dynamiek zodat een } \\
\text { pionier strand ontstaat en water } \\
\text { zich kan verversen, zodat er geen } \\
\text { blauwalg komt, maar niet teveel } \\
\text { dynamiek zodat erosie } \\
\text { tegengegaan wordt. }\end{array}$ & $\begin{array}{l}\text { Met deze maatregel is alleen met } \\
\text { simulatie modellen } \\
\text { geëxperimenteerd bij Hindeloopen. } \\
\text { Lokale ondernemers geven de } \\
\text { voorkeur aan bescherming van het } \\
\text { strand door geotubes, omdat er zo } \\
\text { geen obstakel tussen strand en } \\
\text { meer ontstaat. }\end{array}$ \\
\hline $\begin{array}{l}\text { Versterken dijken } \\
\text { met natuurlijk } \\
\text { ingericht voorland }\end{array}$ & $\begin{array}{l}\text { Zandmotoren, oeverdijken, } \\
\text { vooroevers en/of palenrijen dicht op } \\
\text { de kust. }\end{array}$ & $\begin{array}{l}\text { Om golven af te vlakken, zodat de } \\
\text { dijkhoogte kan verminderen. Langs } \\
\text { de Markermeerdijk tussen } \\
\text { Enkhuizen en Amsterdam worden } \\
\text { om dezelfde reden oeverdijken } \\
\text { aangelegd. } \\
\text { In de BwN pilot Houtribdijk wordt } \\
\text { de effectiviteit van een zandige } \\
\text { vooroever met vegetatie } \\
\text { onderzocht. }\end{array}$ \\
\hline $\begin{array}{l}\text { Overstroming } \\
\text { voorlanden en } \\
\text { buitenwaarden }\end{array}$ & $\begin{array}{l}\text { - Palenrijen, vooroevers en } \\
\text { zandmotoren } \\
\text { - Luwte maatregelen ter } \\
\text { bevordering van rietoevers. } \\
\text { Eventueel in combinatie met } \\
\text { een harde rand. } \\
\text { Risicospreiding / koppelen } \\
\text { natuurgebieden: zorg dat bij } \\
\text { extreme events altijd een } \\
\text { natuurgebied onaangetast blijft. } \\
\text { Het systeem op grotere tijd- en } \\
\text { ruimteschaal benaderen. }\end{array}$ & $\begin{array}{l}\text { Overstroming van de } \\
\text { buitenwaarden is alleen te } \\
\text { voorkomen door de zomerdijk naar } \\
\text { de buitenwaarden te verhogen. De } \\
\text { erosieve effecten van de storm en } \\
\text { de opzet van water zijn te } \\
\text { mitigeren door palenrijen, } \\
\text { zandmotoren en vooroevers. } \\
\text { Effectiviteit van maatregelen is } \\
\text { afhankelijk van de locatie. } \\
\text { Palenrijen langs de Makkumer en } \\
\text { Workumer buitenwaarden kunnen } \\
\text { effectief zijn, daar waar geen } \\
\text { recreatie plaatsvindt. } \\
\text { Rietkragen kunnen effectief zijn in } \\
\text { de wat meer beschutte delen van } \\
\text { de buitenwaarden (bijvoorbeeld } \\
\text { langs de kanalen tussen de } \\
\text { Makkumerwaarden). } \\
\text { Zandmotoren kunnen een golf } \\
\text { verminderend effect hebben, maar }\end{array}$ \\
\hline
\end{tabular}




\begin{tabular}{|l|l|l|}
\hline & & $\begin{array}{l}\text { extra zandinbreng is niet overal } \\
\text { wenselijk (zie eerdere } \\
\text { opmerkingen hierover) }\end{array}$ \\
\hline $\begin{array}{l}\text { Baggerbezwaar } \\
\text { vaargeulen }\end{array}$ & $\begin{array}{l}\text { Slim baggeren is een oplossing om } \\
\text { het zandtransport langs de } \\
\text { westkust deels in stand te houden. } \\
\text { Bijvoorbeeld door zand uit de } \\
\text { vaargeulen noordwaarts van de } \\
\text { vaargeul aan te leggen. }\end{array}$ & $\begin{array}{l}\text { De Workumerbuitenwaard } \\
\text { zandmotor is deels aangelegd met } \\
\text { gebaggerd materiaal uit de } \\
\text { Workumer vaargeul. }\end{array}$ \\
\hline
\end{tabular}

\subsection{Vervolgstappen}

Zoals in Hoofdstuk 1 beschreven, werken Rijk (ministerie I\&M) en regio (provincie Friesland) nu via een pre-verkenning (MIRT) samen aan een maatregelenpakket waarbij naast natuurdoelen ook andere doelen worden gerealiseerd. De maatregelen die in tabel 6.1 worden benoemd, hebben nog nadere onderbouwing nodig. Ook voor de maatregelen die in de pre-verkenning verder worden onderzocht zijn kennisleemtes aanwezig. Dit wordt beschreven in de volgende kennisvragen:

Invalshoek systeemkennis:

- Building with Nature houdt in dat natuurlijke processen worden gebruikt bij ingrepen, en dat meegewerkt wordt met deze processen in plaats van tegengewerkt. Om dit te bewerkstelligen is het essentieel om te begrijpen welke processen spelen en hoe deze processen (morfologisch / ecologisch) op grote tijd en ruimteschaal werken. Dit inzicht in het morfologisch en ecologisch systeem van de Friese kust kan worden verkregen door scenarios te ontwikkelen voor de Friese kust over 100 jaar waarin geen ingrepen of onderhoud zijn uitgevoerd. Een dergelijke analyse geeft inzicht in hoe de processen werken en welke processen gebruikt kunnen worden voor de versterking van de kust, en tegen welke processen het zinloos is om tegen te werken. Het systeem wordt daarmee niet als een statisch systeem beschouwd, maar als een dynamisch systeem. Hiermee kunnen kansen worden geïdentificeerd die buiten beschouwing worden gelaten als het systeem als een statische situatie wordt beschouwd.

Invalshoek BwN maatregelen:

- Zandmotor/dynamisch zandeiland: welke locaties zijn hiervoor geschikt en wat zijn de mogelijke effecten op zandtransport en ecologie?

- Wat zijn effecten van zandingrepen langs de westkust op de vaargeulonderhoud? Verwacht wordt dat deze toeneemt, maar is het mogelijk om dit sediment te bypassen, i.e. van de zuidkant van de vaargeul naar de noordkant te krijgen (door slim baggeren)?

- Wat is de autonome ontwikkeling van de ondiepe vooroever?

- Laag eiland/palenrij: hoe moeten deze eruit zien om de juiste hydrodynamiek (niet te veel en niet te weinig) gerealiseerd wordt? Tot nu toe alleen modelresultaten, de volgende stap is opschalen naar pilot in het veld. 
- Vooroever: dit wordt langs het Markermeer al toegepast (BwN Pilot Houtribdijk), of is in de planfase (Oeverdijk en Markermeer). Voor mogelijke toepassing langs de Friese IJsselmeerkust is het nodig om de juiste locaties hiervoor te identificeren, en in een pilot uit te testen?

- Achteroever: Voorbeelden langs de Noord-Hollandse kust, en de Oostvaardersplassen. Op welke plekken zou dit langs de Friese kust kunnen, en welke belemmeringen zijn er?

- Welke ecodynamische mogelijkheden bestaan er om eilanden te beschermen? Denk aan palenrijen, geotubes, keileemwalletjes, kokosmatten met vegetatie

- Houtribdijk Natuurlijker, zandige versterking Houtribdijk, Oeverdijken Markermeer en MarkerWadden leveren een set (generieke) ontwerphandreikingen voor zachte keringen; deze ontwerphandreikingen kunnen worden uitgebreid en gevalideerd.

Invalshoek mitigatie nieuw peilbeheer:

- Kan voorspeld worden hoe vaak, bij het nieuwe peilbeheer, het peil hoger zal zijn of lager, vergeleken met de huidige situatie?

- Hoe past de morfologie van de ondiepe vooroever en kust zich aan aan het nieuwe peilbeheer? Blijft het diepteprofiel hetzelfde of verdwijnen er dieptebereiken en daarmee habitats?

- Welke effecten zal het nieuwe peilbeheer hebben op de huidige habitattypen? Wat zal er verdwijnen, bijv. steilrandjes, en wat komt er voor terug? Bijv. extra foerageergebied voor vogels in het najaar? Wat zijn de effecten op paaigebied van vis?

- Wat is het optimale peilbeheer van het IJsselmeer voor de aanwezige en gewenste natuurwaarden, ook rekening houden met de vereisten van vis?

- Hoe verzilver je het voordeel van nieuwe peilbesluit, namelijk de ondiepere waterstanden in het najaar (meer foerageergebied). En hoe bestrijd je mogelijk negatieve effecten van hogere waterstanden in voorjaar?

- Kunnen gebieden aan beide kanten van het IJsselmeer worden gekoppeld als natuurgebied? Events aan de westkant van het IJsselmeer komen niet voor aan de oostkant, en andersom. Hierdoor kunnen vogelpopulaties dynamisch in stand worden gehouden.

- Zijn er maatregelen mogelijk om plankton te laten toenemen en daarmee meer voedsel voor vis te genereren? Bijvoorbeeld door eilandjes ook met slib, keileem of klei aan te leggen en zo wat voedselrijkere biotopen te creëren. 


\section{Referenties}

Andeweg H. \& M. Roog (1982) Plantengroei en waterhuishouding op de Workumer Buitenwaard in 1981. Rijksdienst voor IJsselmeerpolders Werkdocument 1982-207 Abw.

Bak A., W.M. Liefveld, H.A.M. Prinsen en F. van Vliet (2007) Evaluatie natuurontwikkelingsprojecten IJsselmeergebied, rapport 07-120, Bureau Waardenburg, Culemborg.

Folmer, Wilms, Steijn \& Cleveringa (2010) Pilot eco-dynamiek Fryske kust. Alkyon rapport A2448R1r1, in opdracht van Ecoshape.

Deltacommissie (2008). Samen werken met Water. Een land dat leeft, bouwt aan zijn toekomst.

Deltaprogramma, 2014. Een veilig en Veerkrachtig IJsselmeergebied. Synthesedokument

Eco-recover (2015). Monitoring of the vegetation development in the Workumer Buitenwaarden for assessing the effects of sand nourishment

Ecoshape, 2011. Morfologische modellering Building with Nature pilot Oudemirdum. Notitie 20 december 2011. 075955474:0.1

Fiselier et al. (2011). Perspectief Natuurlijke keringen: een eerste verkenning ten behoeve van het Deltaprogramma. Building with Nature - Ecoshape.

Groot A., G. Lenselink, E. van Slobbe, G. van Meurs, R. Noordhuis, A. Wiersma, M. Bos, I. Pasmans, P. Dankers \& T. Wilms (2012) Natuurlijk IJsselmeer: Ecodynamische visie IJsselmeer 2100. Ecoshape rapport.

Groot, A., Lenselink, G, de Vlieger, B. en Janssen, S. (2012). Morfologische, ecologische en governance principes voor ecodynamisch ontwerpen: Toegespitst op de 'Bouwen met Natuur' pilots Friese IJsselmeerkust.

Kater B., R. Snoek \& I. Pasmans (2012) Monitoring en modellering Workumerwaard. Arcadis rapport.

Kater B. (2015) Ecologische monitoring Friese kust. Building with Nature. Datarapport 2015. Arcadis rapport.

Koenjer C.H.M., W.H. Hulsegge \& J. Postma (2002) Monitoring van waterplanten en perifyton in het IJsselmeergebied 2001. RDIJ-rapport 2001-24.

Lauwaars S.G. en Platteeuw, M. 1999. Een groene Riem onder het Natte Hart, Een groene riem onder het Natte Hart: Evaluatie van natuurontwikkelingsprojecten in het IJsselmeergebied. RIZA rapport nr.: 99.030 
Menke U. \& G. Lenselink (1997) Buitendijkse gebieden langs de Friese IJsselmeerkust; een dynamisch evenwicht! RIZA Rapport nr. 97.075.

Slager H. (1983). De waterhuishouding van natuurgebieden langs de Friese IJsselmeerkust. 3 Workumer buitenwaard. Rijksdienst voor IJsselmeerpolders Werkdocument 1983-48 Abw.

Slager H. \& G.F.J. Smit (1989). De waarden langs de Friese IJsselmeerkust: samenhang tussen bodem, hydrologie en vegetatie. Wetenschappelijke Mededeling KNNV nr. 194.

de Vriend, H.J. \& M. van Koningsveld (2012). Building with Nature: Thinking, acting and interacting differently. EcoShape, Building with Nature, Dordrecht, the Netherlands.

Wal, M. van der, Giri, S. (2013). Historische ontwikkeling van de Friese IJsselmeerkust. De vaargeulen van Hindeloopen en Workum.

Wiersma, A.P., W. Sommer, P. Doornenbal, 2013. Morphological effects of a sand nourishment on a shallow shoreface in the IJsselmeer, offshore Workum. Dordrecht. Building with Nature.

Witteveen+Bos (2014). Modelstudie kustvak Molwerum - Workumerwaard. 


\section{A Bijlage A}

Stand van zaken monitoring zandmotoren langs de Friese IJsselmeerkust 


\section{Inhoud}

1 Introductie 1

1.1 Aanleiding 1

1.2 Doelstelling 1

2 Gebiedsomschrijving en methodes 2

2.1 Workum 2

2.2 Oudemirdum 4

3 Resultaten 6

3.1 Workum 6

3.2 Oudemirdum 32

4 Discussie $\quad 48$

5 Conclusie en aanbevelingen $\quad 49$

6 Referenties $\quad 50$

Bijlage(n)

$\begin{array}{ll}\text { A Bijlagen } & \text { A-1 }\end{array}$

A.1 Workum A-1

A.1.1 Tabel sedimentvolume ten opzichte van T0, van T1 en van de voorgaande tijdstap. $\quad A-1$

A.1.2 Tabel sedimentvolume suppletie A-1

A.1.3 Tabel sedimentvolume diep $\quad$ A-2

A.1.4 Tabel sedimentvolume ondiep $\quad$ A-2

A.1.5 Profielen A-3

A.2 Oudemirdum A-5

A.2.1 Tabel sedimentvolume ten opzichte van T0, van T1 en van de voorgaande tijdstap. A-5

A.2.2 Tabel sedimenvolume suppletie $\quad$ A-5

$\begin{array}{lll}\text { A.2.3 Profielen A-6 } & \end{array}$ 


\section{Introductie}

\subsection{Aanleiding}

Als reactie op voorgenomen peilveranderingen in het IJsselmeer in het kader van het Deltaprogramma besloten Friese partijen (waterschap, gemeenten, provincie en natuurorganisatie It Fryske Gea) om op twee locaties experimenten uit te voeren naar manieren om de kust op een natuurlijke manier mee te laten groeien. De experimenten bestaan uit kleinschalige suppleties van zand op de ondiepe vooroevers van het IJsselmeer. De hypothese is dat dit zand door golven naar de kust wordt gebracht en daarmee de (voor)oevers versterkt. Deze vorm van suppleren, waarbij een grote hoeveelheid zand door natuurlijke processen verder wordt verspreid, wordt 'zandmotor' genoemd. De zandmotor moet tot een duurzamer, goedkoper en ecologisch robuuster resultaat leiden dan de bestaande kunstmatige eilanden en vooroevers in het IJsselmeer. Om dit te testen is een uitgebreid monitoringprogramma opgezet dat de ecologische en morfologische effecten van de zandmotoren in het IJsselmeer volgt.

De eerste zandmotor is aangelegd bij Workum en in oktober 2011 opgeleverd. Deze kustparallelle suppletie is langwerpig van vorm en heeft een volume van $31.000 \mathrm{~m}^{3}$. Het zand is gesuppleerd op ongeveer 600 meter afstand van de kust, en op ongeveer 50 meter van het steile talud dat de overgang vormt naar dieper water. De tweede zandmotor is in april $2013 \mathrm{bij}$ Oudemirdum opgeleverd en heeft een volume van $11.500 \mathrm{~m}^{3}$. De suppletie is haakvormig aangelegd, beginnend op ongeveer 50 meter van de kust aan de noordzijde en eindigend op ongeveer 400 meter van de kust aan de zuidkant. De overgang naar dieper water ligt op meer dan 100 meter afstand van de zuidkant van de suppletie.

\subsection{Doelstelling}

In dit rapport worden de resultaten van de monitoring tot en met de zomer van 2014 behandeld. Het is doel is om een tussentijdse update te geven van de nu beschikbare data, en op basis hiervan voorlopige conclusies te trekken over of en hoe het aanbrengen van suppleties de kust van het IJsselmeer beschermt. De belangrijkste vraag hierbij is hoe het zand wordt verspreid en of dit tot versterking of meegroeien van de oevers leidt. 


\section{Gebiedsomschrijving en methodes}

De twee gebieden waar de zandmotoren zijn aangelegd liggen in het noordoosten van het IJsselmeer, voor de kust van Friesland (Figuur 2.1). In de volgende paragrafen wordt een beschrijving van het gebied rondom beide zandmotoren gegeven en worden de uitgevoerde analyses beschreven.

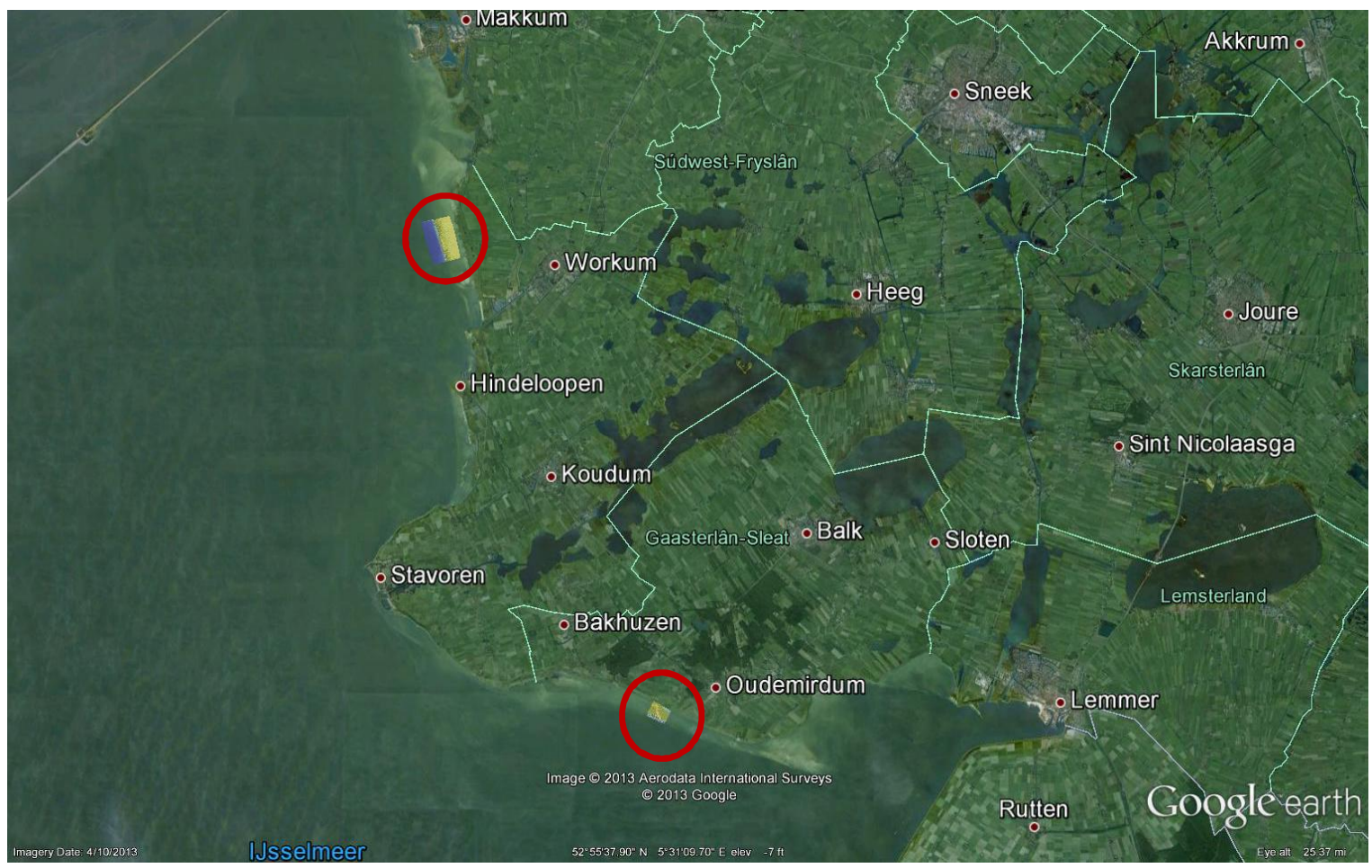

Figuur 2.1 Locatie van de pilotprojecten Workum en Oudemirdum langs de Friese IJsselmeerkust

\subsection{Workum}

De zandmotor bij Workum is in oktober 2011 opgeleverd. De suppletie bestaat uit een rug van zand van 100 meter bij 600 meter parallel aan de kust. Het volume zand dat is aangebracht is ongeveer $31.000 \mathrm{~m}^{3}$. In het noorden van het onderzoeksgebied is een dam geplaatst die tot sedimentatie ten zuiden van deze dam moet leiden. Deze dam bestaat uit verticale houten palen met ruimtes ertussen (palenrij). Een overzicht van het gebied is te zien in Figuur 2.2.

In dit document worden de morfologische effecten beschreven, zoals die zijn waargenomen sinds het aanbrengen van de suppletie tot en met de zomer van 2014. Deze effecten worden beschreven op basis van dieptepeilingen die tot de zomer van 2013 tweejaarlijks en sindsdien één keer per jaar worden uitgevoerd (Tabel 2.1).

De peilingen zijn aangeleverd als xyz bestanden door Shore Monitoring and Research. De metingen zijn uitgevoerd met een Single Beam Echolood en een drijfconstructie met DGPS (Shore, 2014b). De meetonzekerheid in deze metingen is rond de $5 \mathrm{~cm}$ in de verticaal. De meetpunten zijn geïnterpoleerd naar rasters met een anisotrope kriging methode van het 
softwarepakket ArcGIS. Deze methode houdt rekening met de richting van de zandruggen die in het gebied aanwezig zijn en de zandmotor die daar parallel mee is aangelegd. Er zijn verschilkaarten gemaakt van alle rasters ten opzichte van de beginsituatie (T0) en ten opzichte van de situatie direct na aanleg van de zandmotor (T1). Op basis van deze verschilkaarten zijn veranderingen in sedimentvolume berekend voor het hele gebied (Vtotaal) en voor de suppletie zelf (V-suppletie). Het volledige gebied is ook ingedeeld op basis van de diepte in meting T1 in een deel boven en een deel onder $2 \mathrm{~m}$ - NAP.

Het gebied waarin de T0 meting is uitgevoerd is kleiner omdat dit slechts de uitgangssituatie voor het aanleggen van de suppletie moest vastleggen. Vanaf de T1 meting is de bathymetrie van een groter gebied gemeten zodat ook de morfologische effecten van de suppletie vastgelegd konden worden.

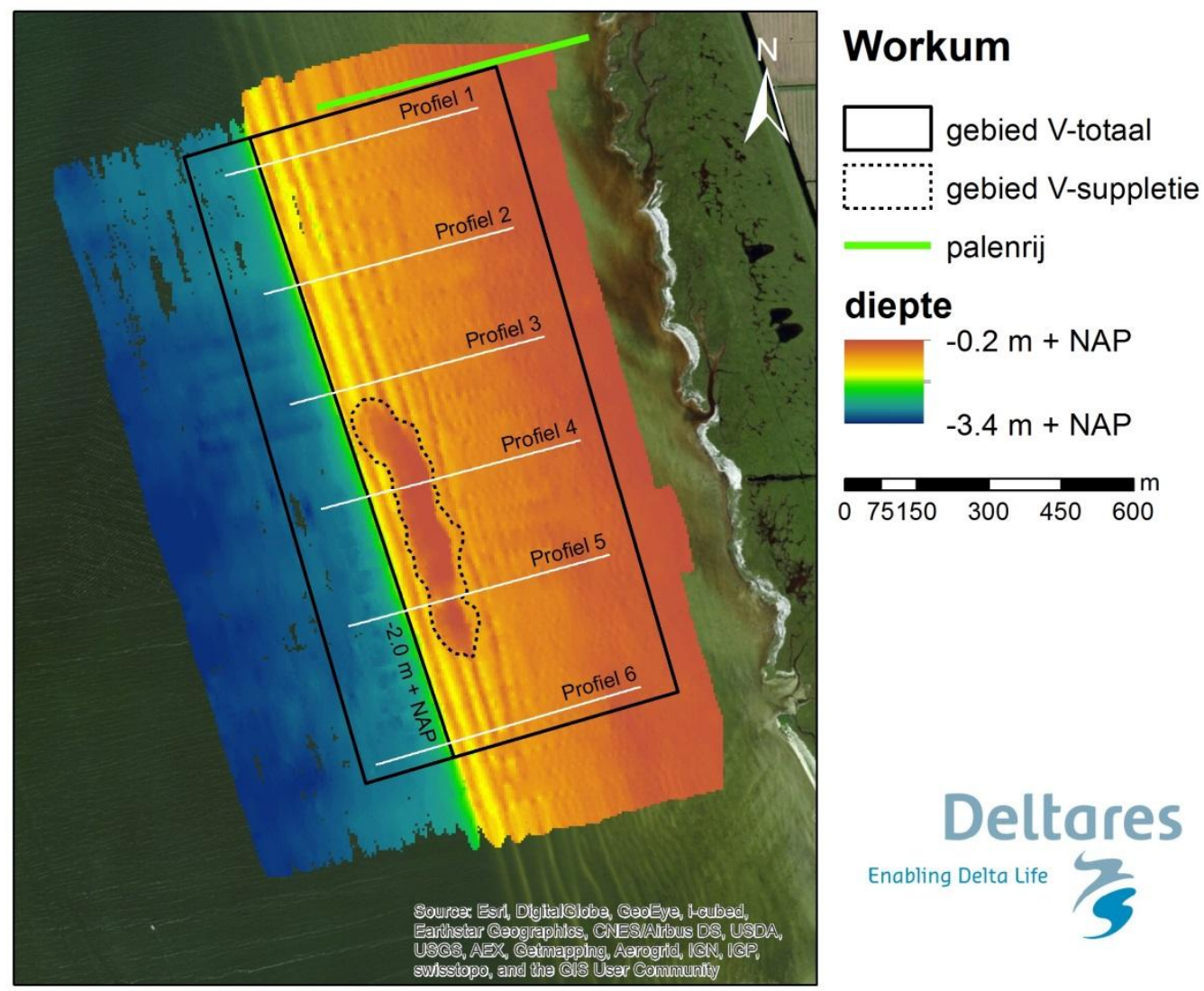

Figuur 2.2 Bathymetrie na aanbrengen van de suppletie in april 2013 (T1), met daarin aangegeven de locaties van de profielen en gebieden waarvoor veranderingen en sedimentvolume zijn berekend. 
Tabel 2.1 Tijdstappen bathymetrische opnamen bij Workum.

\begin{tabular}{|l|l|l|}
\hline Tijdstap & $\begin{array}{l}\text { Datum } \\
\text { peilwerkzaamheden }\end{array}$ & Opmerkingen \\
\hline T0 & April 2011 & Beginsituatie \\
\hline T1 & Oktober 2011 & Na aanbrengen suppletie \\
\hline T2 & April 2012 & \\
\hline T3 & Oktober 2012 & \\
\hline T4 & Juni 2013 & \\
\hline T5 & Juli 2014 & \\
\hline T6 & Mei 2015 & \\
\hline
\end{tabular}

\subsection{Oudemirdum}

De zandmotor bij Oudemirdum bestaat uit een haak dwars op de kust van $11.500 \mathrm{~m}^{3}$ zand en is begin 2013 opgeleverd (Figuur 2.3). De monitoring van deze zandmotor is kleiner opgezet dan die bij Workum en bestaat uit monitoring van de morfologie (Deltares) en aquatische ecologie (Arcadis); op deze laatste wordt in deze rapportage niet ingegaan. Om de morfologische effecten van de zandmotor te bepalen is tot nu toe vier keer een dieptepeiling in het gebied uitgevoerd door Shore Monitoring and Research: één keer voor de aanleg van de suppletie (de T0 situatie) en vier keer na de aanleg van de suppletie (T1 tot en met T4 opnamen, zie tabel 2.2).

De dieptepeilingen van Oudemirdum zijn geïnterpoleerd naar rasters met de Nearest Neighbour methode van het softwarepakket ArcGIS. Voor deze methode is gekozen omdat, in tegenstelling tot Workum, in Oudemirdum geen preferente interpolatierichting bestaat omdat de suppletie in een hoek op aan de aanwezige zandruggen is aangelegd.

Verschilplots zijn gemaakt om veranderingen in bathymetrie ten opzichte van eerdere tijdstappen te analyseren. Sedimentvolume is berekend voor het totale gebied (V-totaal) en de suppletie (V-suppletie). Aan de randen van de verschilplots zijn anomalieen zichtbaar die voortkomen uit kleine verschillen in ingemeten gebied (bijvoorbeeld Figuur 3.32; Figuur 3.36). Deze zijn daarom buiten het gebied gehouden waarvoor volume berekend is. 


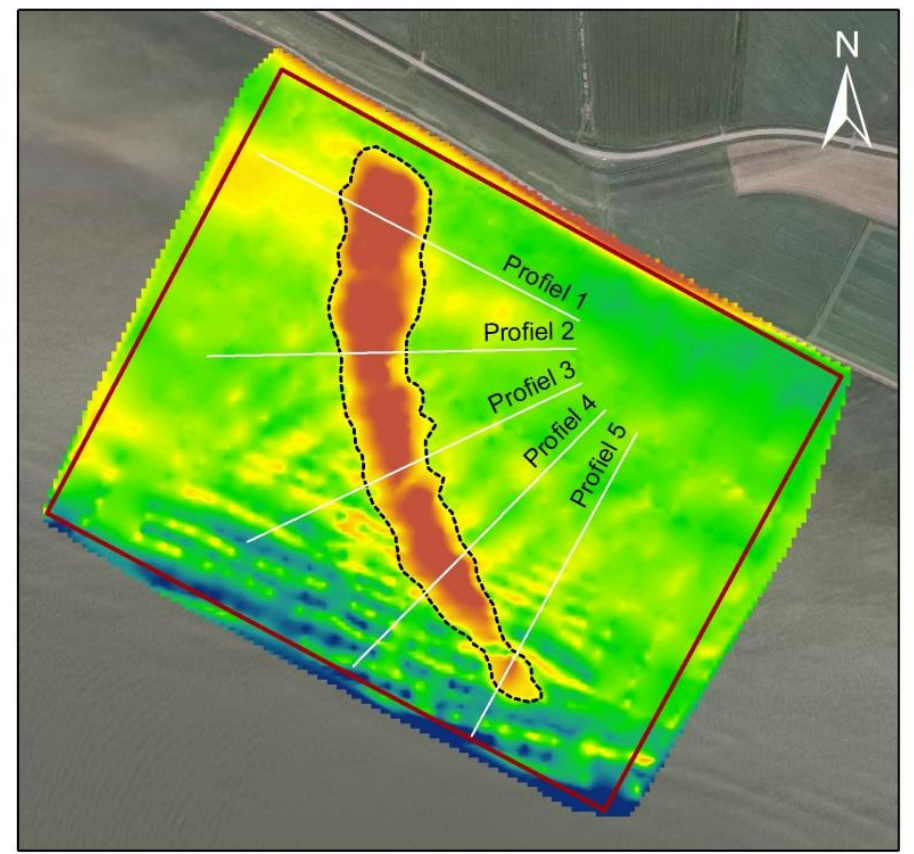

\section{Oudemirdum}

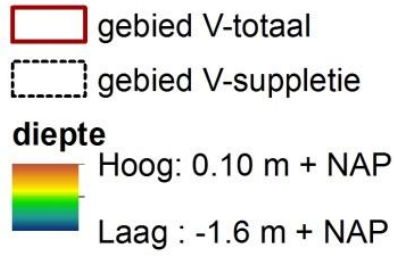

$0 \quad 60120180240300$

\section{Deltares}

Enabling Delta Life

Figuur 2.3 Bathymetrie na aanbrengen van de suppletie in april 2013 (T1), met daarin aangegeven de locaties van de profielen en gebieden waarvoor veranderingen en sedimentvolume zijn berekend.

Tabel 2.2 Tijdstappen bathymetrische opnamen bij Oudemirdum.

\begin{tabular}{|l|l|l|}
\hline Tijdstap & $\begin{array}{l}\text { Datum } \\
\text { peilwerkzaamheden }\end{array}$ & Opmerkingen \\
\hline T0 & Oktober 2012 & Beginsituatie \\
\hline T1 & April 2013 & Na aanbrengen suppletie \\
\hline T2 & November 2013 & \\
\hline T3 & April 2014 & \\
\hline T4 & Mei 2015 & \\
\hline
\end{tabular}




\section{Resultaten}

\subsection{Workum}

De morfologische veranderingen worden weergegeven aan de hand van een reeks figuren. Deze figuren tonen de bathymetrie (Figuur $3.3 \mathrm{t} / \mathrm{m}$ Figuur 3.8), verschilplots tussen de tijdstappen (Figuur $3.10 \mathrm{t} / \mathrm{m}$ Figuur 3.14) en profielen loodrecht op de kust (Figuur 2.1Figuur 3.1, Bijlage A.1).

De bathymetrische opname is in T0 uitgevoerd voor een kleiner oppervlak dan voor volgende tijdstappen, omdat deze slechts de uitgangssituatie in beeld moest brengen. Veranderingen als gevolg van het aanbrengen van de suppletie in het omliggende gebied zullen pas in latere tijdstappen zichtbaar zijn. De T0 situatie (Figuur 3.3) laat de diepteligging van de vooroever zien. Duidelijk zichtbaar zijn het diepere IJsselmeer aan de westkant, een steil talud naar de ondiepe vooroever en de zandruggen die parallel aan de kust lopen landwaarts van dit talud. De zandruggen zijn het hoogst net landwaarts van het talud, en nemen in hoogte af richting de kust. Ze lopen van noord naar zuid ononderbroken door. Over het algemeen lijken de zandruggen zich langzaam uit de kust te verplaatsen en ter hoogte van het talud in hoogte af te nemen en te verdwijnen (zie de profielen in Bijlage A.1.5).

In de T1 opname (Figuur 3.4) is duidelijk de net aangelegde suppletie te zien in het gebied met de kustparallelle zandruggen. Het verschilfiguur tussen T1 en T0 opname (Figuur 3.10) laat de suppletie zien als een rode vlek (sedimentatie) met duidelijke grenzen. De suppletie is over de kustparallelle zandruggen heen gelegd, die daardoor afgedekt zijn. Het berekende sedimentvolume van de suppletie is $20.000 \mathrm{~m}^{3}$. Dit is minder dan de aangebrachte 31.000 $\mathrm{m}^{3}$. Afgezien van lichte verplaatsing van de zandruggen is weinig sedimentatie of erosie zichtbaar.

De T2 opname (Figuur 3.5) laat een duidelijke afvlakking van de suppletie zien, en het herstel van de kustparallelle ruggen ter plaatse van de suppletie. De herstellende zandruggen sluiten aan de zuidkant van de suppletie aan bij de oorspronkelijke ligging. Aan de noordkant is er echter een verplaatsing ten opzichte van de oorspronkelijke ligging opgetreden. Hierdoor sluit de tweede zandrug ter hoogte van de suppletie aan op de derde zandrug ten noorden ervan. Het verschilplot tussen T2 en T1 (Figuur 3.16) toont dat er ten noorden van de suppletie erosie heeft plaatsgevonden langs het talud. Dit patroon geeft een lichte verschuiving van de zandruggen vlak ten noorden van de suppletie.

De T3 opname (Figuur 3.6) toont een voortzetting van de patronen die bij de T2 opname te zien zijn: een verdere afvlakking van de suppletie en de verdergaande vorming van kustparallelle zandruggen ter plaatse van de suppletie. Richting kust lijkt tussen tijdstap T2 en T3 sedimentatie van 5 à 10 centimeter te hebben plaatsgevonden (Figuur 3.21). Bovendien vindt er extra sedimentatie plaats ten noorden van de suppletie in langwerpige ruggen. Dit sediment is waarschijnlijk afkomstig uit de suppletie. Dit is ook goed te zien in het verschilplot tussen de T3 en T0 situatie (Figuur 3.12). Ten noorden van de palenrij lijkt tussen T2 en T3 erosie opgetreden (Figuur 3.21). Deze T3 metingen ten noorden van de palenrij wijken echter af van alle andere metingen. Het gaat hier waarschijnlijk om een meetfout. 
Tussen de T3 en T4 opnamen (Figuur 3.7; Figuur 3.13; Figuur 3.22) zet het patroon van sedimentatie zich, tot circa $200 \mathrm{~m}$ ten noorden van de initiële suppletie, voort. In dit gebied zijn de zandruggen van de kust vandaan verplaatst, en komen zo weer meer in lijn met de ligging van de zandruggen ten zuiden van de suppletie. De oorspronkelijk buitenste zandrug neemt in hoogte af en verdwijnt daardoor langzaam, wat te zien is in profiel 2 (Bijlage A.1.5.). De overige ruggen zijn toegenomen in hoogte, mogelijk gevoed door zand vanuit de suppletie. Sedimentatie kustwaarts van de suppletie is tussen T3 en T4 verwaarloosbaar, met een grootte in de orde van $5 \mathrm{~cm}$ (Figuur 3.22). Ten noorden van de palenrij heeft sedimentatie plaatsgevonden ten opzichte van meting T3. Dit gaat echter waarschijnlijk om een meetartefact omdat meting T3 erg afwijkt van andere metingen ten noorden van de palenrij.

In opname T5 (Figuur 3.8) is de suppletie in het veld niet meer te zien als een ondieper deel (Shore 2014b), maar sedimentatie ten noorden ervan heeft zich verder voortgezet (Figuur 3.14). De buitenste kustparallele ruggen lopen nu weer ononderbroken door. In de tijdstap van T4 naar T5 (Figuur 3.23) heeft erosie plaatsgevonden aan de noordkant van de dam, en sedimentatie aan de zuidzijde. Tijdens veldobservaties voor beiden tijdstappen is waargenomen dat sediment aan de noordkant van de dam hoger ligt dan aan de zuidkant ervan.

In de meest recente opname T6 vindt veel erosie en sedimentatie plaats op en tussen de zandruggen ten noorden van de suppletielocatie (Figuur 3.9; 3.16), wat duidt op verplaatsing van de zandruggen. Ten noorden van de suppletie vindt sedimentatie plaats langs het talud tussen de vooroever en het ijsselmeer, zoals te zien in profiel 1 en 2 in Bijlage A1.5. In deze profielen is ook te zien dat relatief hoge zandruggen zich ten noorden van de suppletie hier verder kustwaarts beginnen te vormen dan in de rest van het gebied.

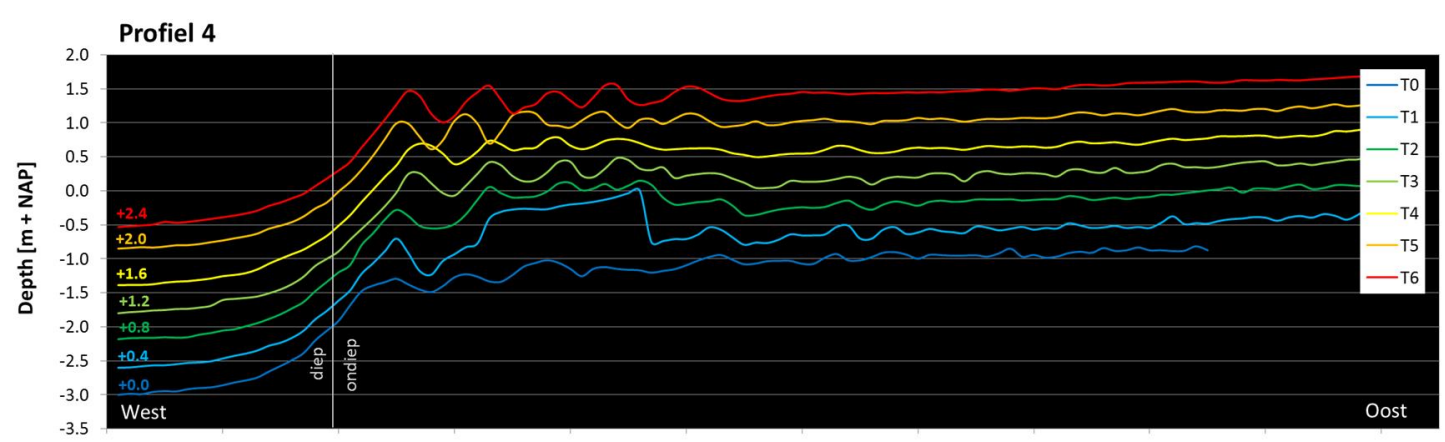

Figuur 3.1 Dwarsprofiel van de suppletie voor T0 t/m T6. Het profiel is $600 \mathrm{~m}$ lang. Het afvlakken van de suppletie is duidelijk waarneembaar. Het gebied op en direct rondom de suppletie is erg dynamisch, terwijl het deel ten oosten van de suppletie minder dynamisch is en er vrijwel geen sedimentatie plaatsvindt. 


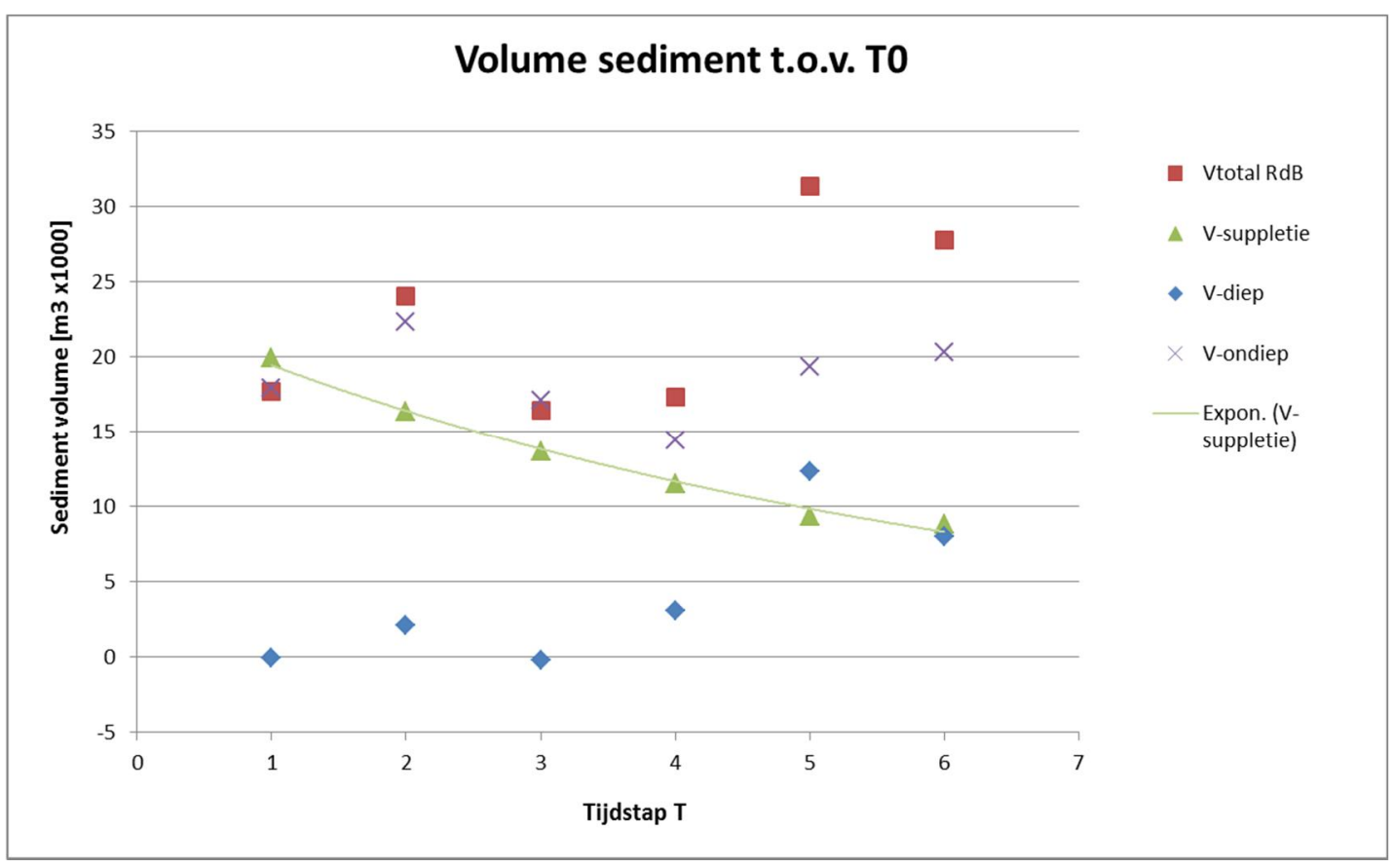

Figuur 3.2 Sedimentvolume voor het gehele gebied, ten westen van het talud (diep) en ten oosten van het talud (ondiep) en in de suppletie. Er is een duidelijke afnemende trend zichtbaar in het sedimentvolume in de het suppletiegebied.

Volumeberekeningen zijn uitgevoerd in verschillende zones in het studiegebied, zijnde (1) het gehele studiegebied, (2) het diepe en (3) ondiepe bereik, gescheiden door de 2-meter dieptelijn in tijdstap T1 en (4) het gebied waarin de suppletie oorspronkelijk is aangelegd. De resultaten van de volumeberekeningen zijn te vinden in bijlage Workum en staan weergegeven in Figuur 3.2.

De toename in sedimentvolume tussen T0 en T1 kan worden toegeschreven aan het aanbrengen van de suppletie. Het verschil in sedimentvolume tussen T0 en T1 $\left(20.000 \mathrm{~m}^{3}\right)$ komt niet overeen met het sedimentvolume dat bij aanleg zou zijn gebruikt $\left(31.000 \mathrm{~m}^{3}\right)$. Dit kan komen door interpolatie artefacten, verlies van sediment bij de aanleg van de suppletie (bijvoorbeeld het uitspoelen van de fijne fractie), door erosie die plaatsvond in de tijd die is verstreken tussen het begin van de aanleg en de bathymetrische opname van T1, en door verschillen in pakking van het sediment tussen beun en depositie in water.

Zoals verwacht neemt het sedimentvolume in het gebied waarin de suppletie is aangelegd ten opzichte van T0 af met de tijd, waarbij de snelheid van afname geringer wordt naarmate de tijd vordert. Sedimentaire processen verspreiden het aangebrachte sediment over een groter gebied. In de dwarsprofielen (Figuur 3.1; bijlage A.1.5) is te zien dat de zandruggen zich lateraal verplaatsen. De richting van deze verplaatsing is niet te bepalen uit de afzonderlijke profielen. Het totale sedimentvolume tussen aanleg van de suppletie en de laatste bathymetrische opnamen van het gehele gebied vertoont een grillig patroon. Het totaalvolume aan sediment ten opzichte van beginmeting T0 is overal positief, en in de helft van de metingen zelfs groter dan het volume van de suppletie die is aangebracht. Dit suggereert dat een groot deel van het aangebrachte sediment in het gebied blijft. De grilligheid zegt wel iets over de onzekerheid aan die wordt geïntroduceerd bij het interpoleren van de lijninformatie van de dieptemetingen. De grootschalige patronen zijn betrouwbaarder voor de analyse. 
Opvallend is de sterke toename in sedimentvolume van T5 in het diepe bereik ten opzichte van voorgaande tijdstappen (Figuur 3.2,, Figuur 3.8, Figuur 3.23). Ook in de nieuwe T6 diepteopname is het sedimentvolume direct ten westen van de $-2 m$ NAP lijn relatief hoog. De volumetoename lijkt te zijn veroorzaakt door het uitbouwen van de ondiepe vooroever richting het IJsselmeer. Opvallend is deze uitbouw direct ten noorden van de suppletie lijkt plaats te vinden. Dit duidt mogelijk op uitbouw als gevolg van het extra gesuppleerde zand. 


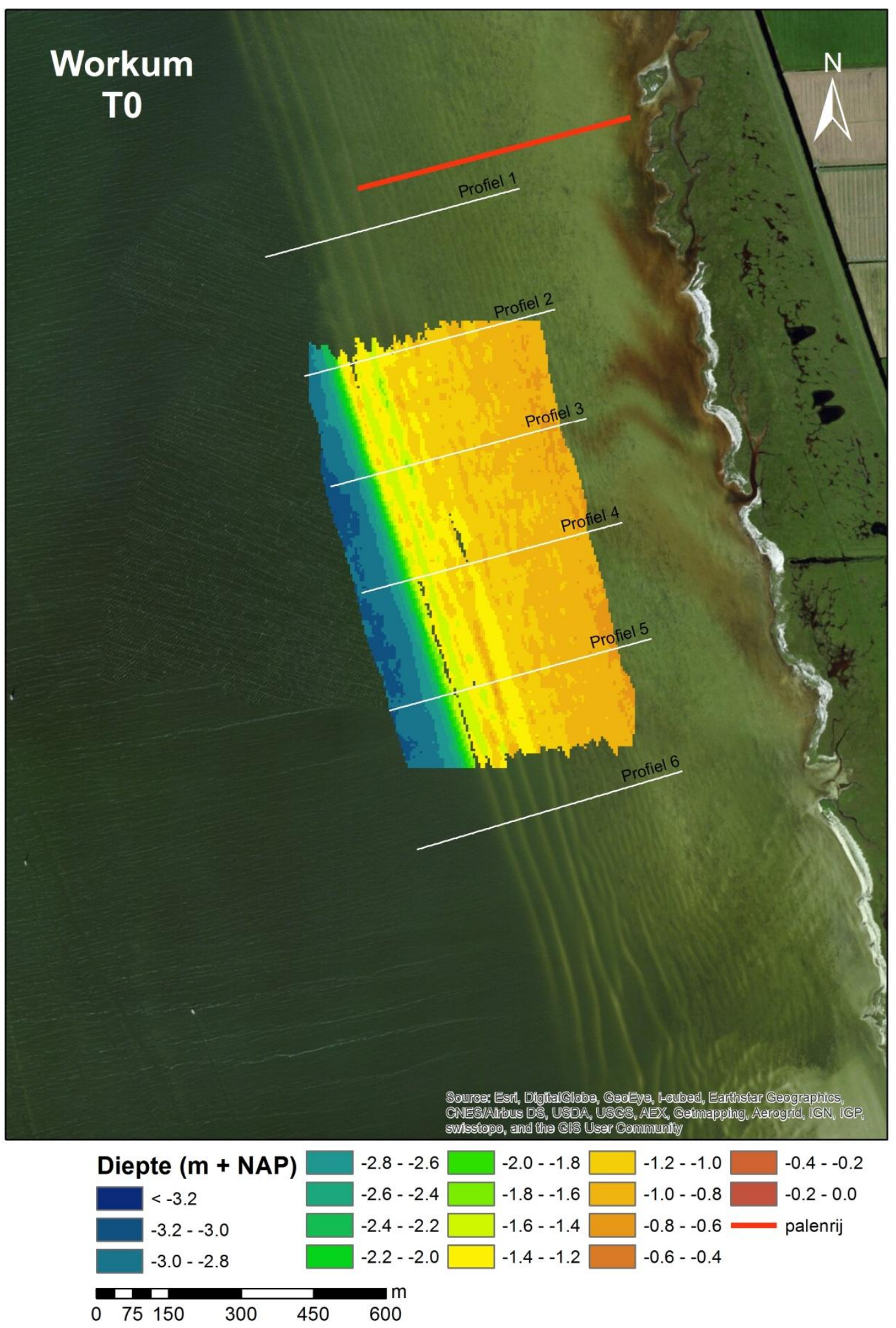

Figuur 3.3 Bathymetrie van de uitgangssituatie van de vooroever voordat de suppletie is aangelegd (TO). De data zijn opgenomen in april 2011. De rode lijn aan de noordkant geeft de positie van de palenrij aan. 


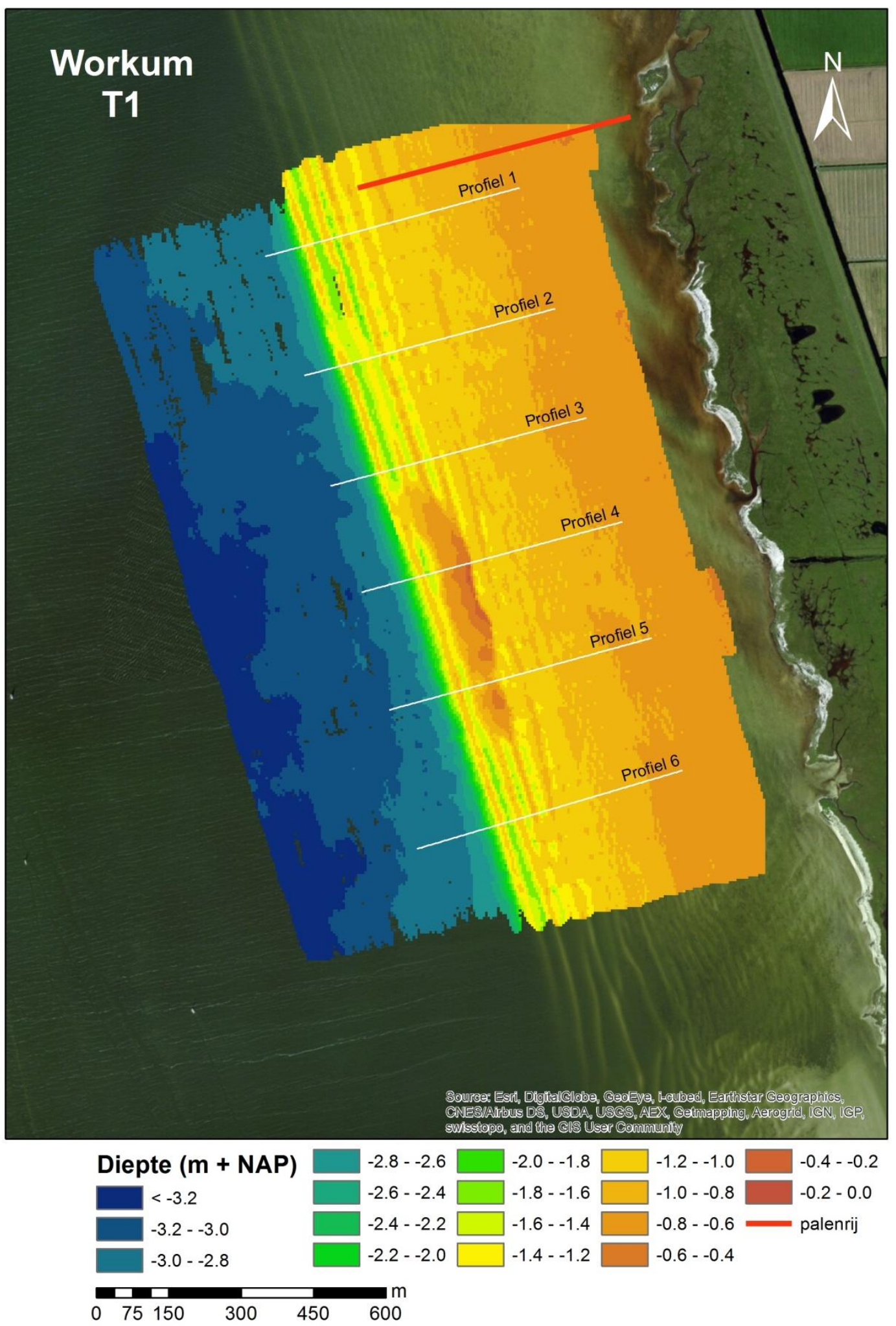

Figuur 3.4 Bathymetrie van de vooroever direct nadat de suppletie is aangelegd (T1). De data zijn opgenomen in oktober 2011 


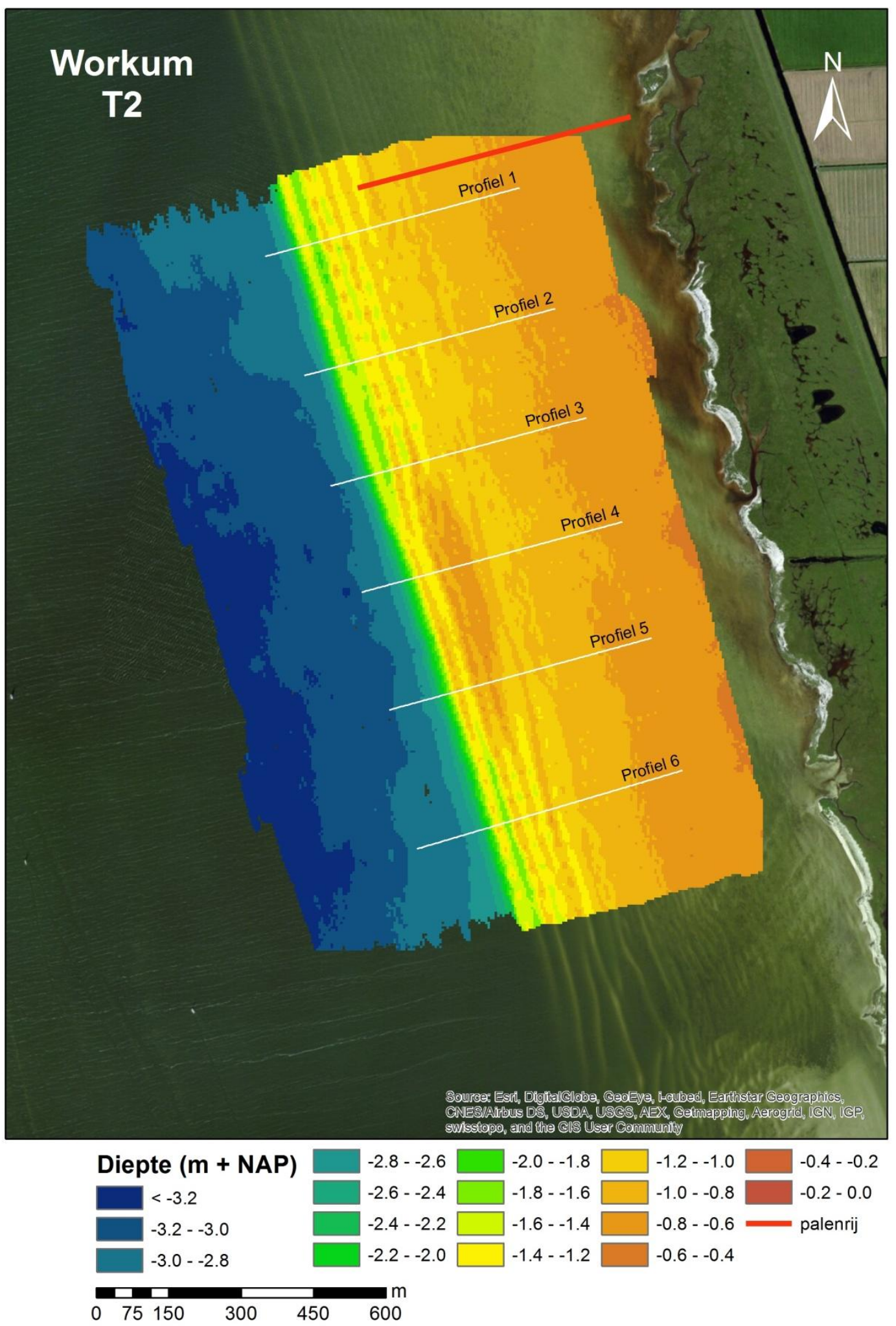

Figuur 3.5 Bathymetrie van de vooroever een half jaar nadat de suppletie is aangelegd (T2). De data zijn opgenomen in april 2012. 


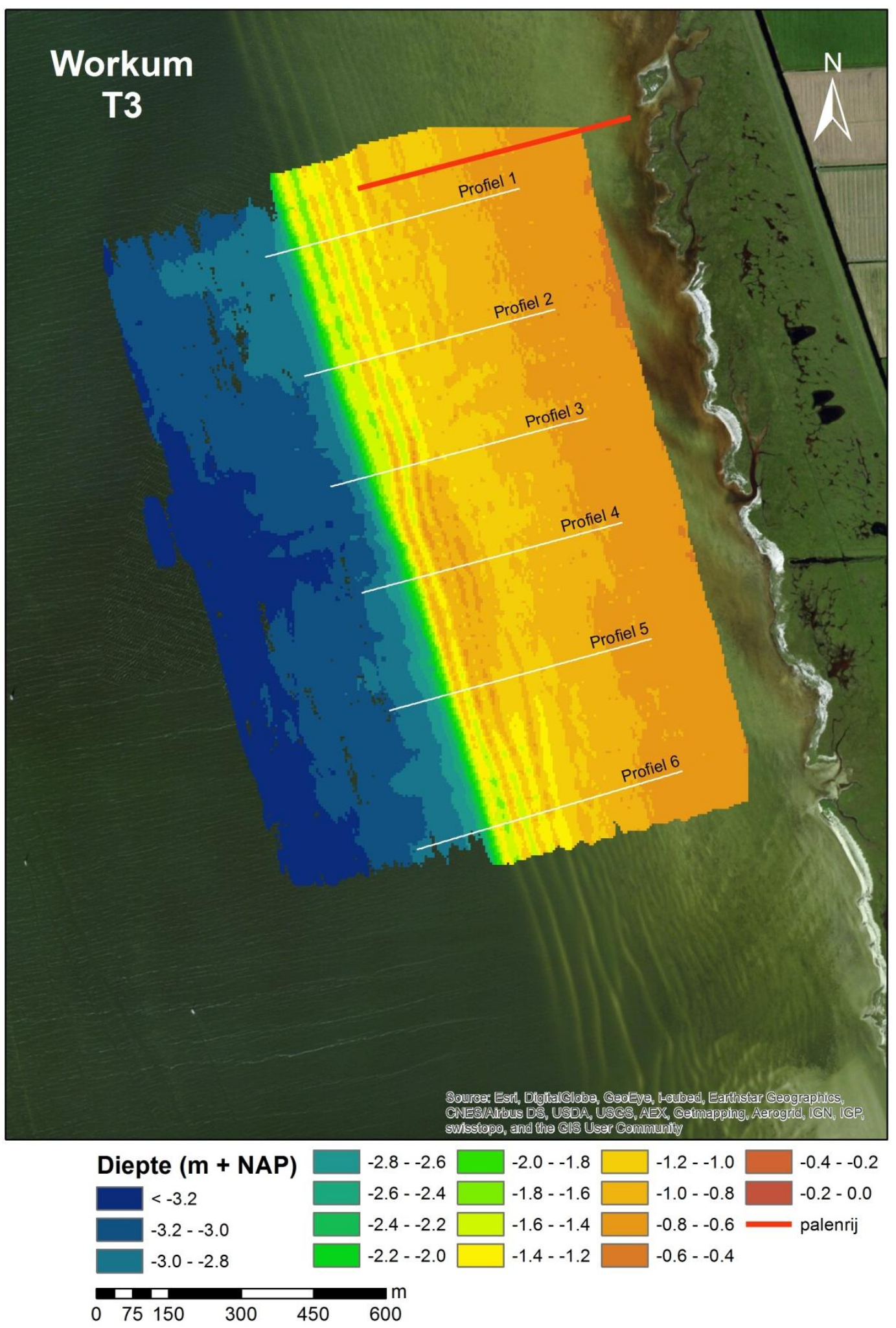

Figuur 3.6 Bathymetrie van de vooroever een jaar nadat de suppletie is aangelegd (T3). De data zijn opgenomen in oktober 2012. 


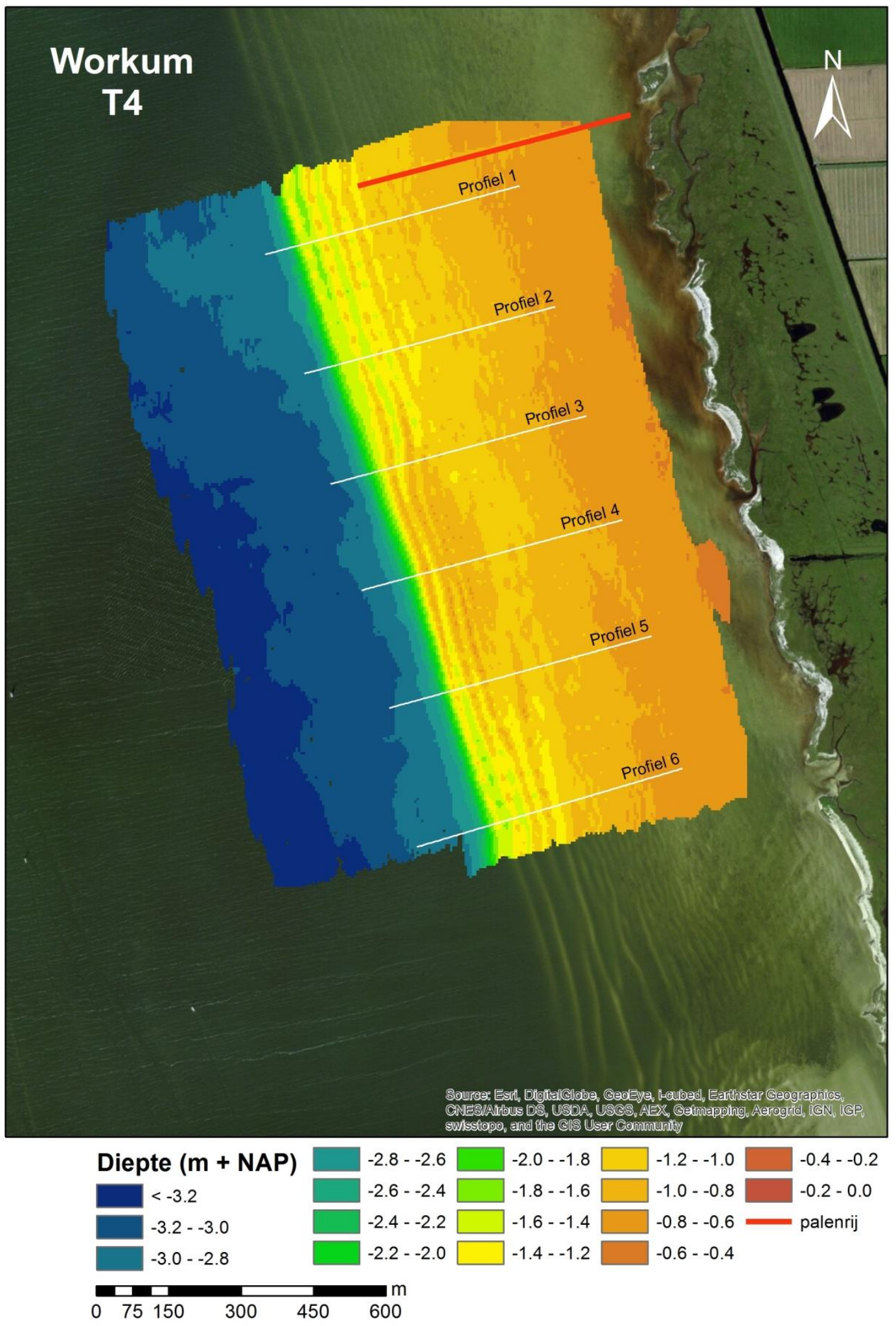

Figuur 3.7 Bathymetrie van de vooroever anderhalf jaar nadat de suppletie is aangelegd (T4). De data zijn opgenomen in juni 2013. 


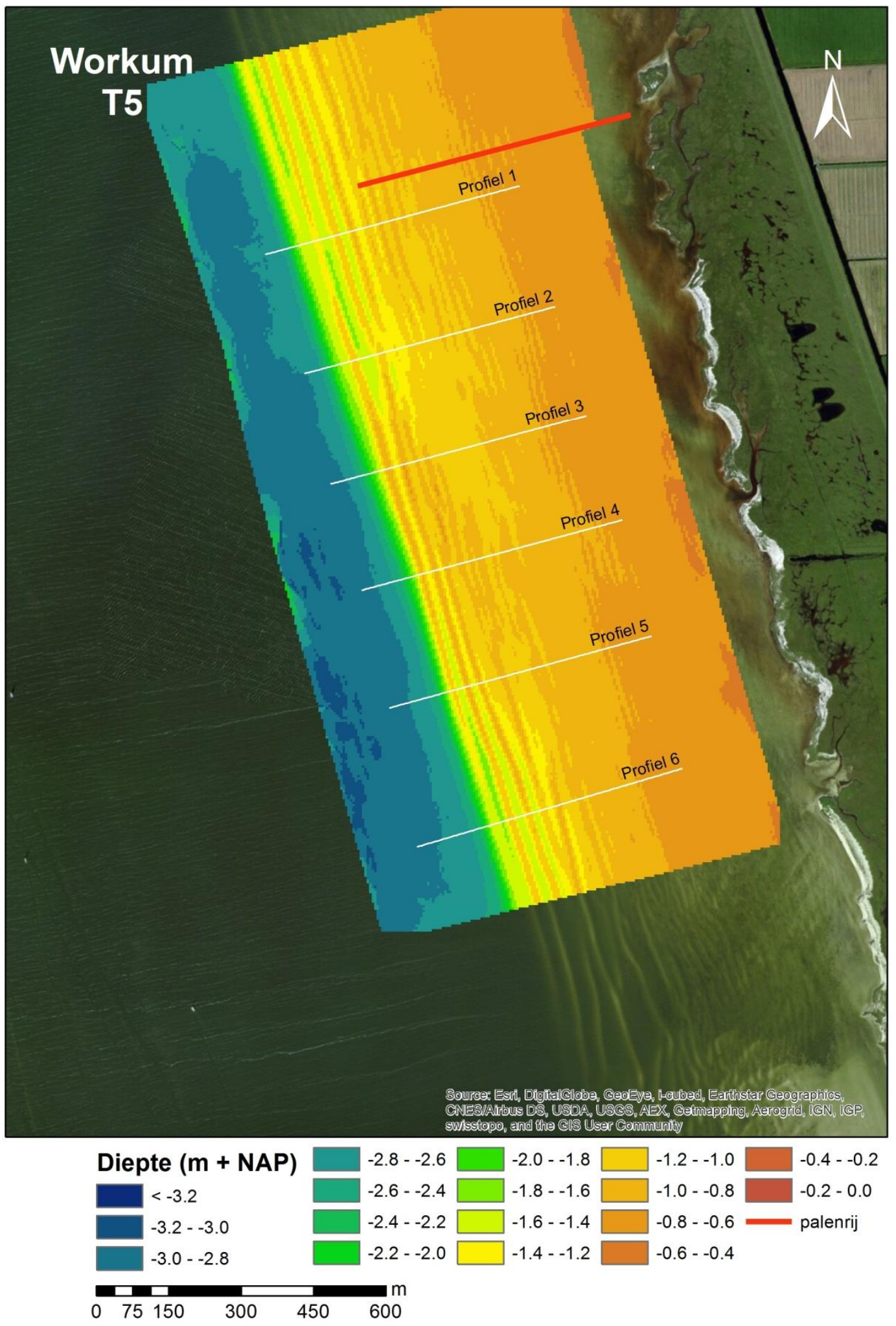

Figuur 3.8 Bathymetrie van de vooroever twee en een half jaar nadat de suppletie is aangelegd (T5). De data zijn opgenomen in juli 2014. 


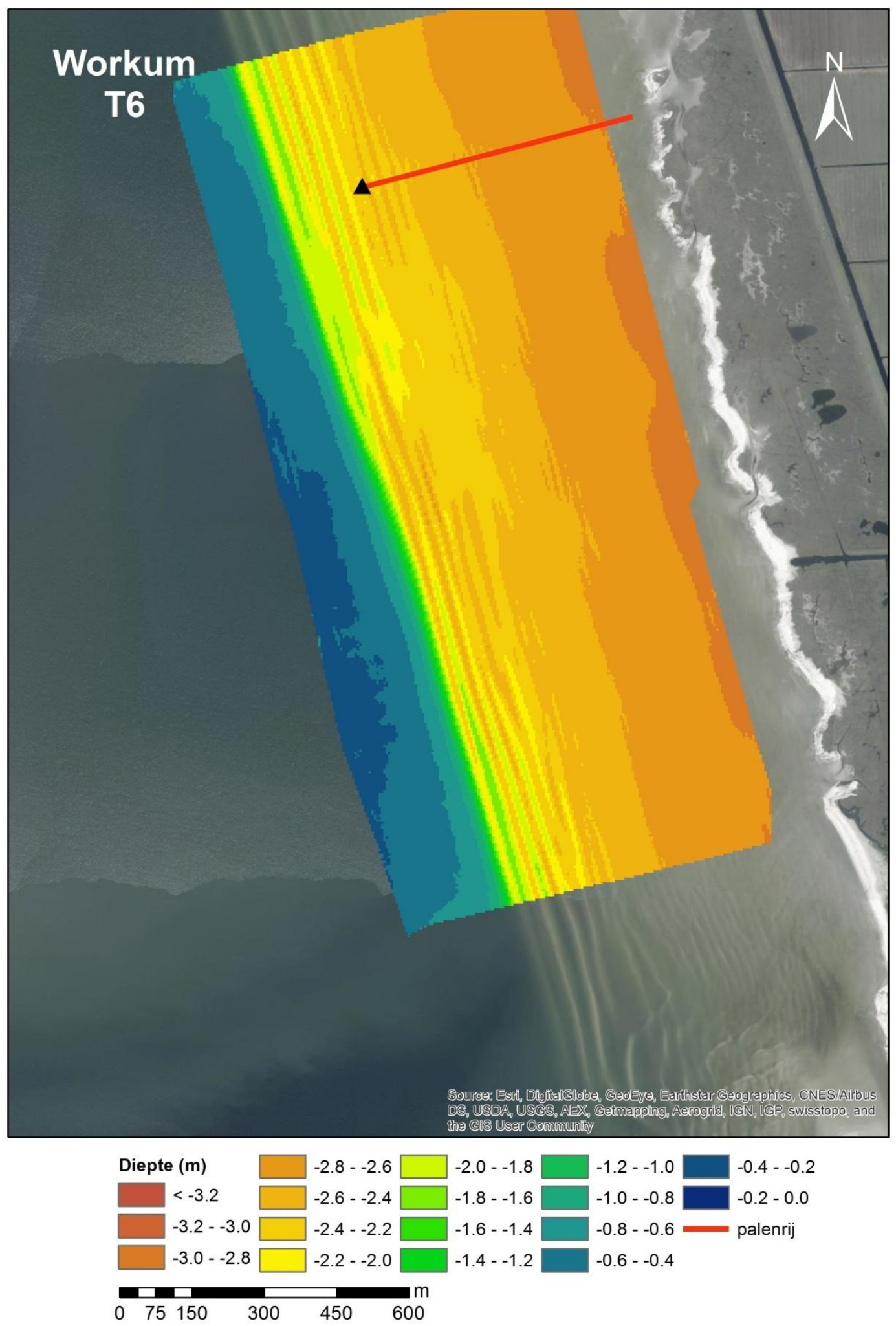

Figuur 3.9 Bathymetrie van de vooroever drie en een half jaar nadat de suppletie is aangelegd (T6). De data zijn opgenomen in mei 2015. 


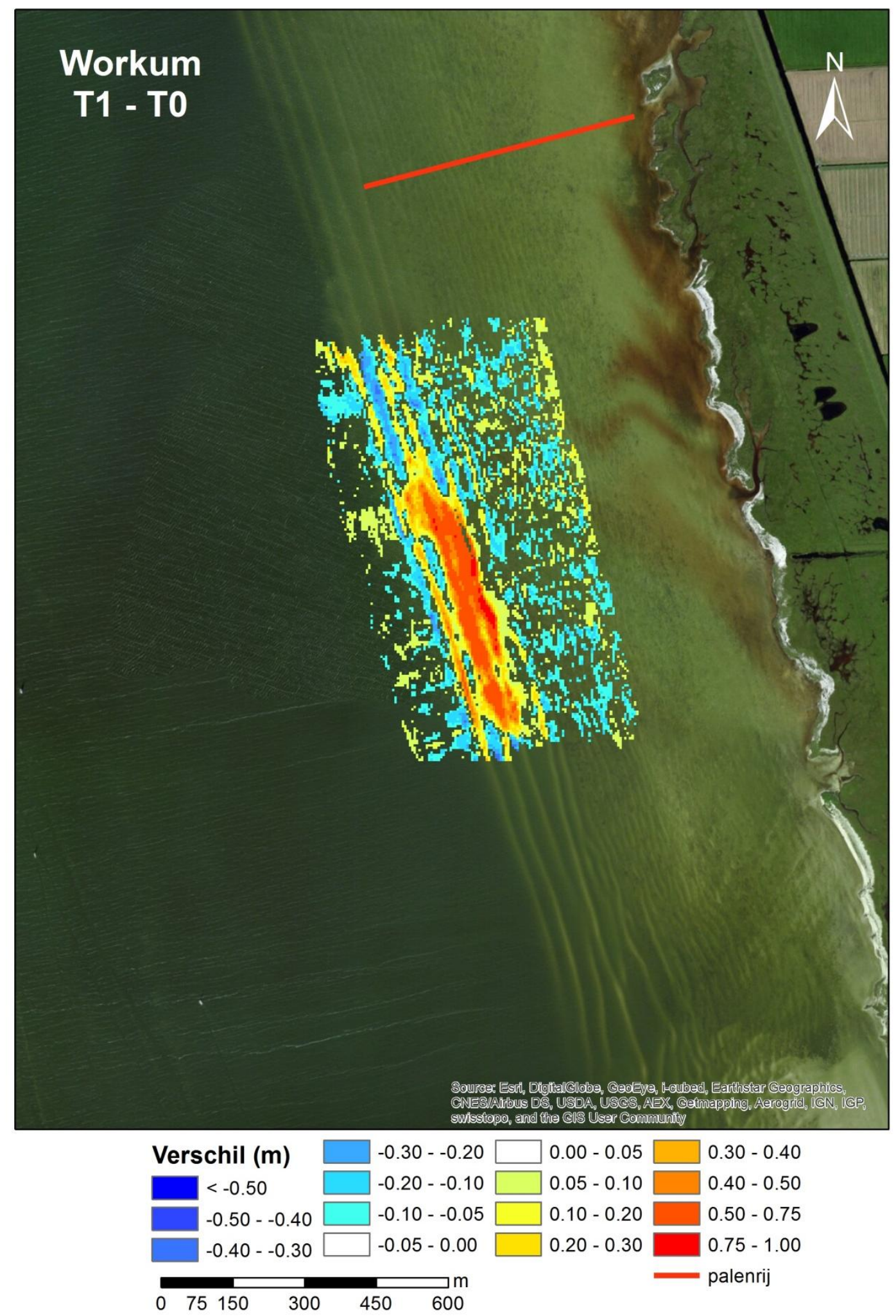

Figuur 3.10 Verschilplot van de bathymetrie tussen de TO en T1 opname. Gele en rode kleuren geven sedimentatie weer, blauwe kleuren geven erosie weer. 


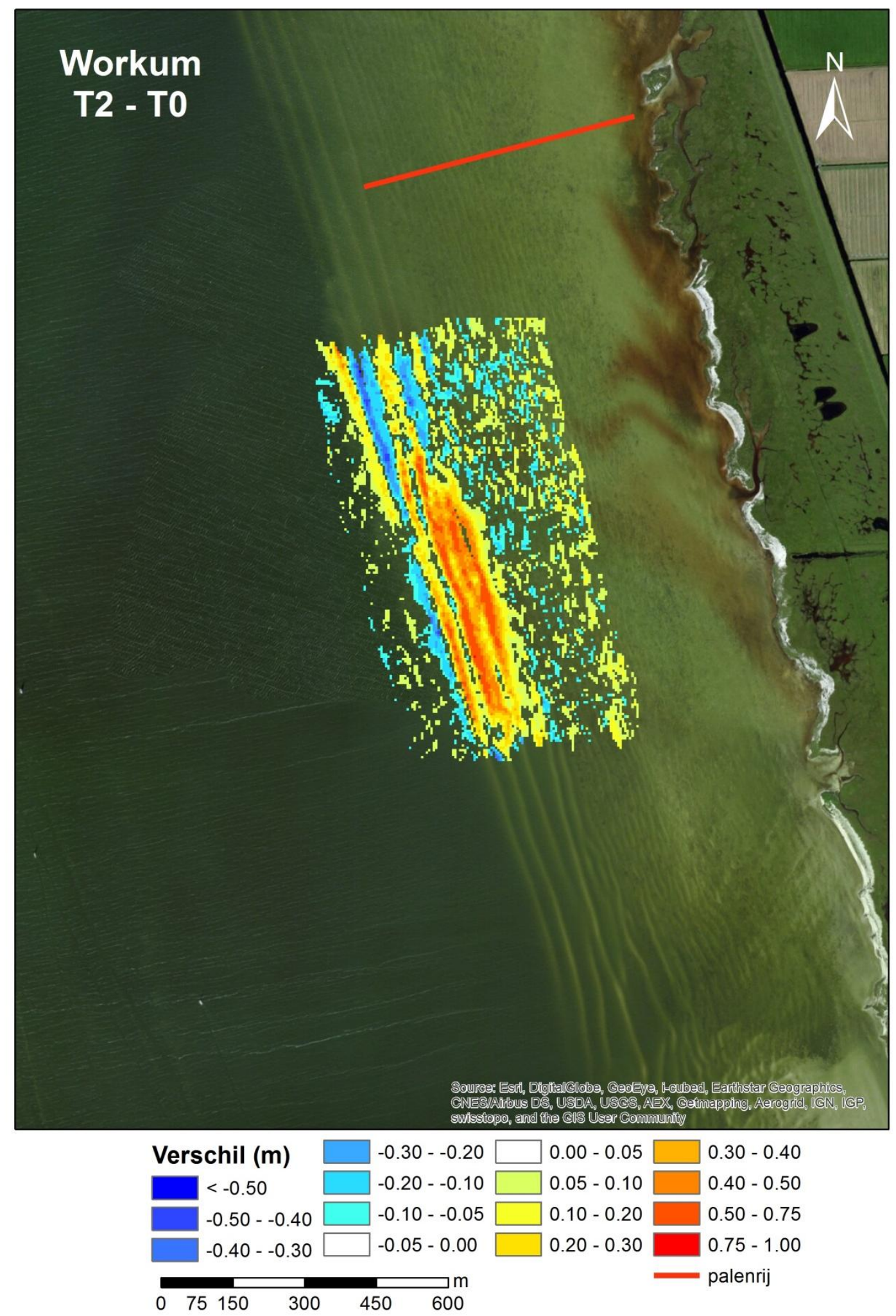

Figuur 3.11 Verschilplot van de bathymetrie tussen de TO en T2 opname. Gele en rode kleuren geven sedimentatie weer, blauwe kleuren geven erosie weer. 


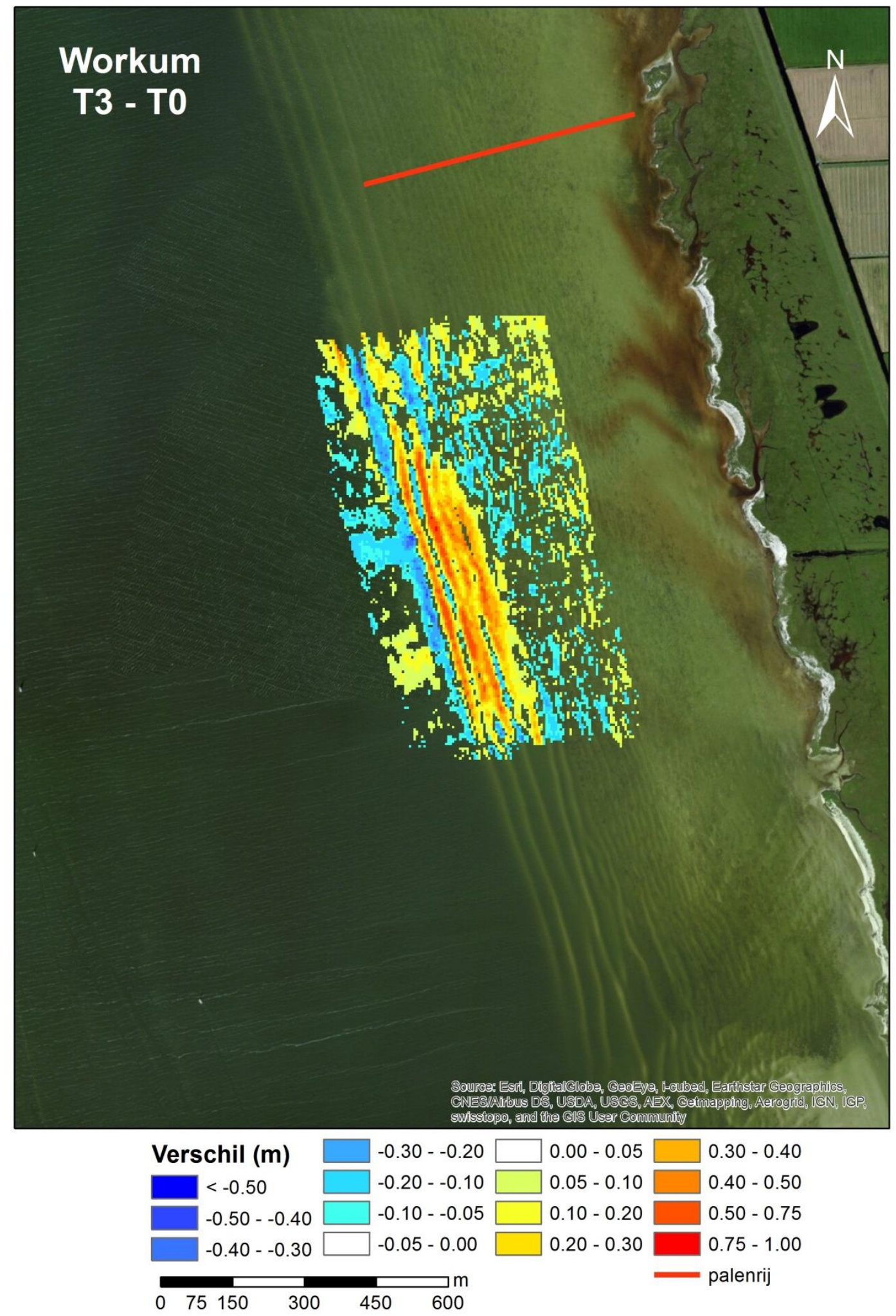

Figuur 3.12 Verschilplot van de bathymetrie tussen de TO en T3 opname. Gele en rode kleuren geven sedimentatie weer, blauwe kleuren geven erosie weer. 


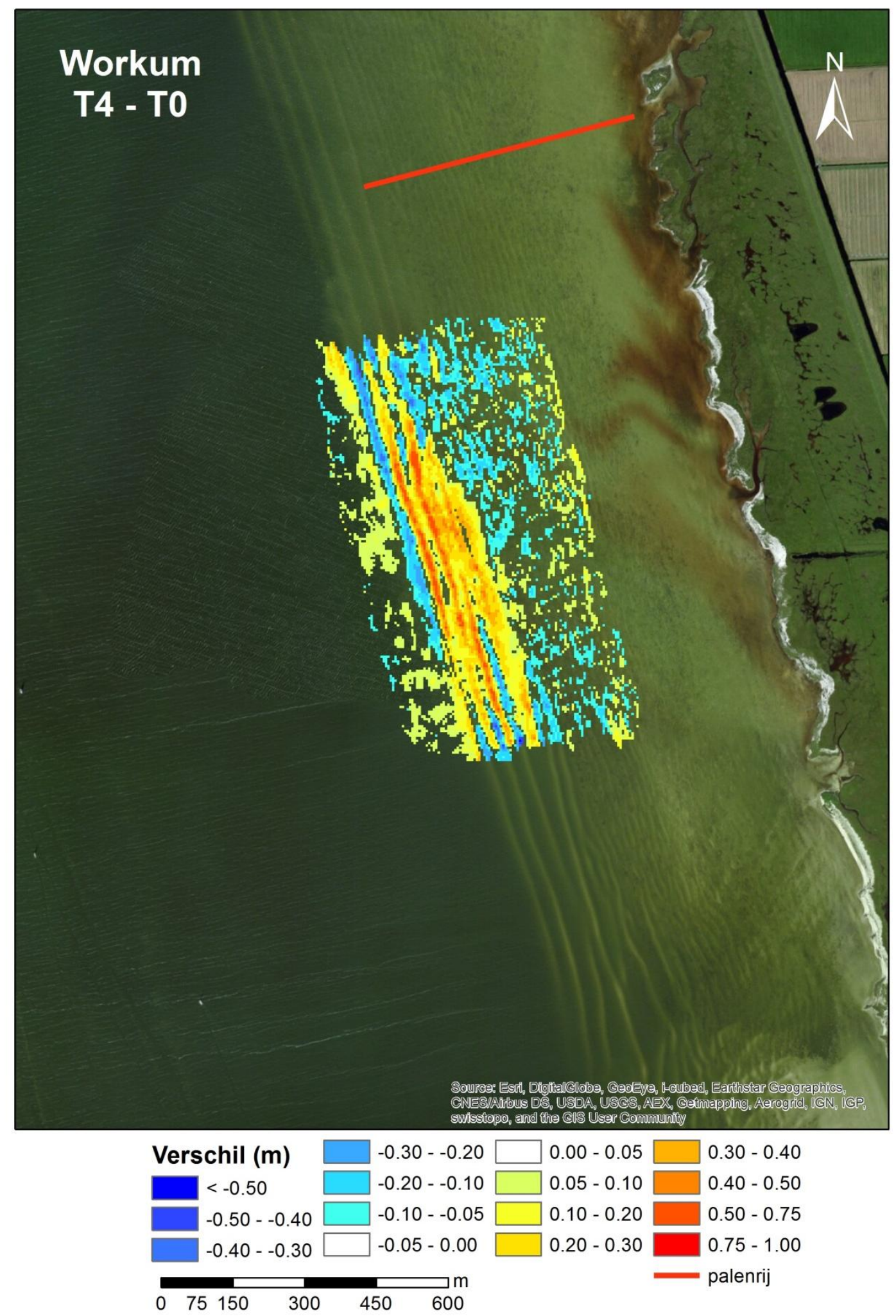

Figuur 3.13 Verschilplot van de bathymetrie tussen de TO en T4 opname. Gele en rode kleuren geven sedimentatie weer, blauwe kleuren geven erosie weer. 


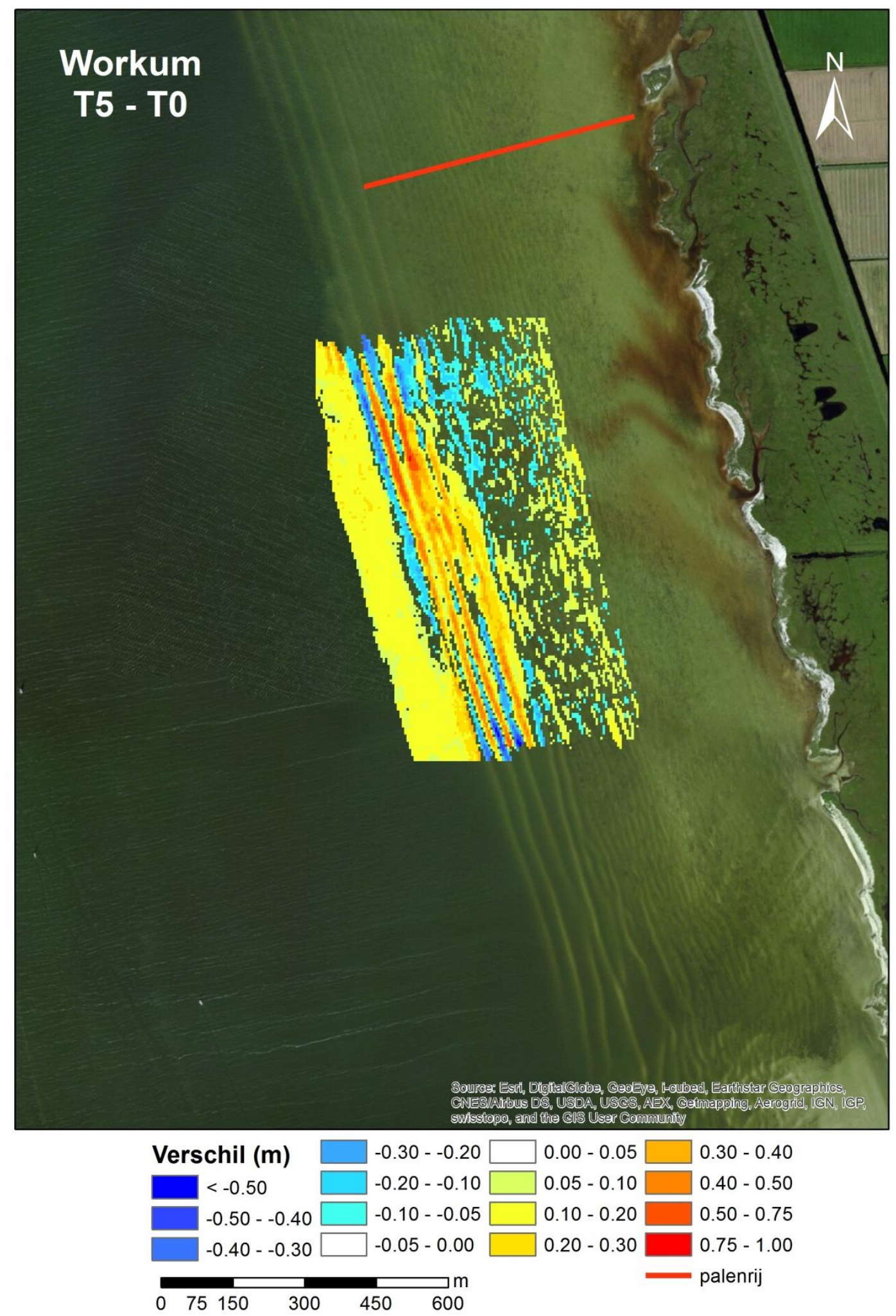

Figuur 3.14 Verschilplot van de bathymetrie tussen de TO en T5 opname. Gele en rode kleuren geven sedimentatie weer, blauwe kleuren geven erosie weer. 


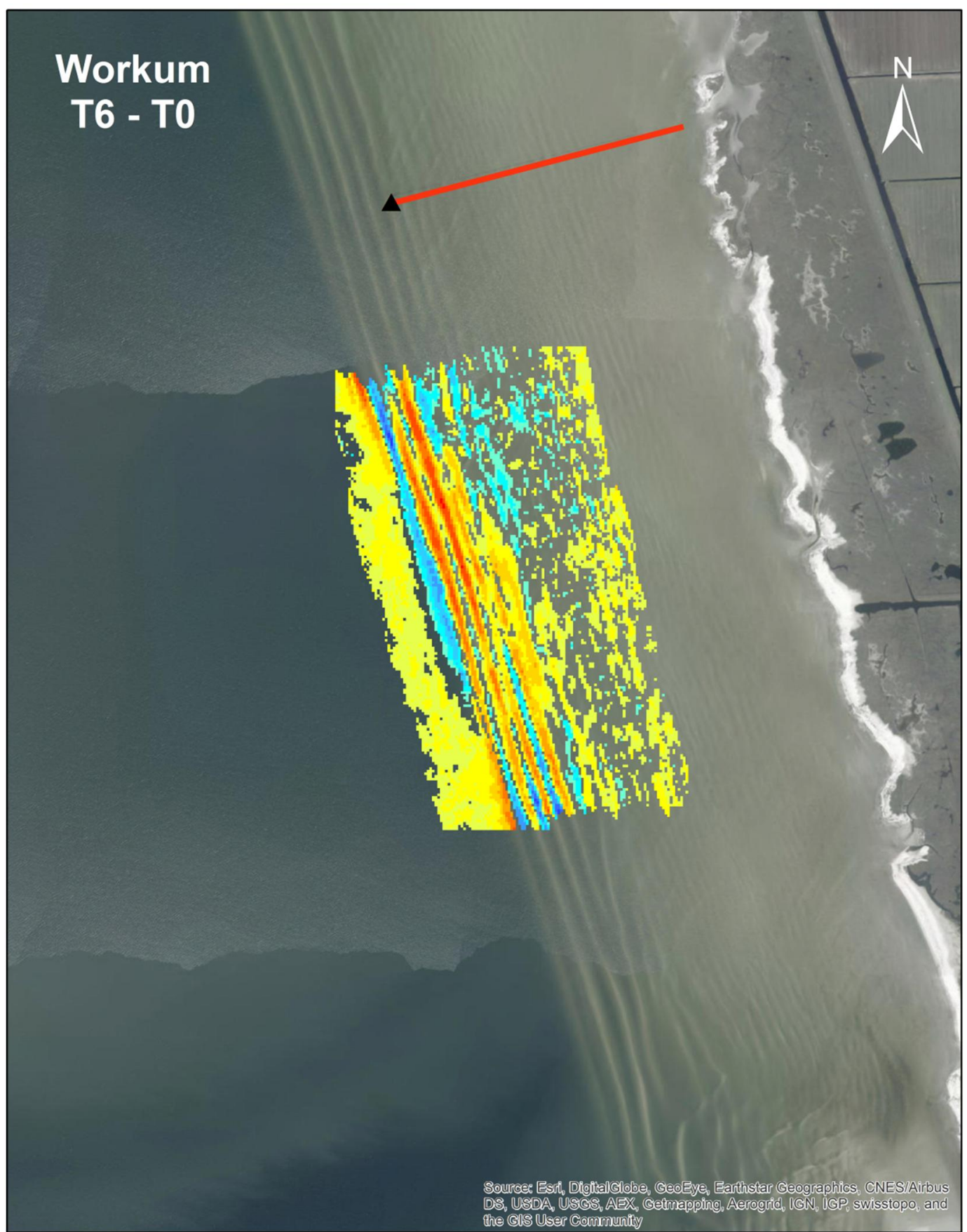

\begin{tabular}{|c|c|c|c|}
\hline Verschil (m) & $-0.30--0.20$ & $0.00-0.05$ & $0.30-0.40$ \\
\hline$<-0.50$ & $-0.20--0.10$ & $0.05-0.10$ & $0.40-0.50$ \\
\hline$-0.50--0.40$ & $-0.10--0.05$ & $0.10-0.20$ & $0.50-0.75$ \\
\hline$-0.40--0.30$ & $-0.05-0.00$ & $0.20-0.30$ & $0.75-1.00$ \\
\hline
\end{tabular}

Figuur 3.15 Verschilplot van de bathymetrie tussen de T0 en T6 opname. Gele en rode kleuren geven sedimentatie weer, blauwe kleuren geven erosie weer. 


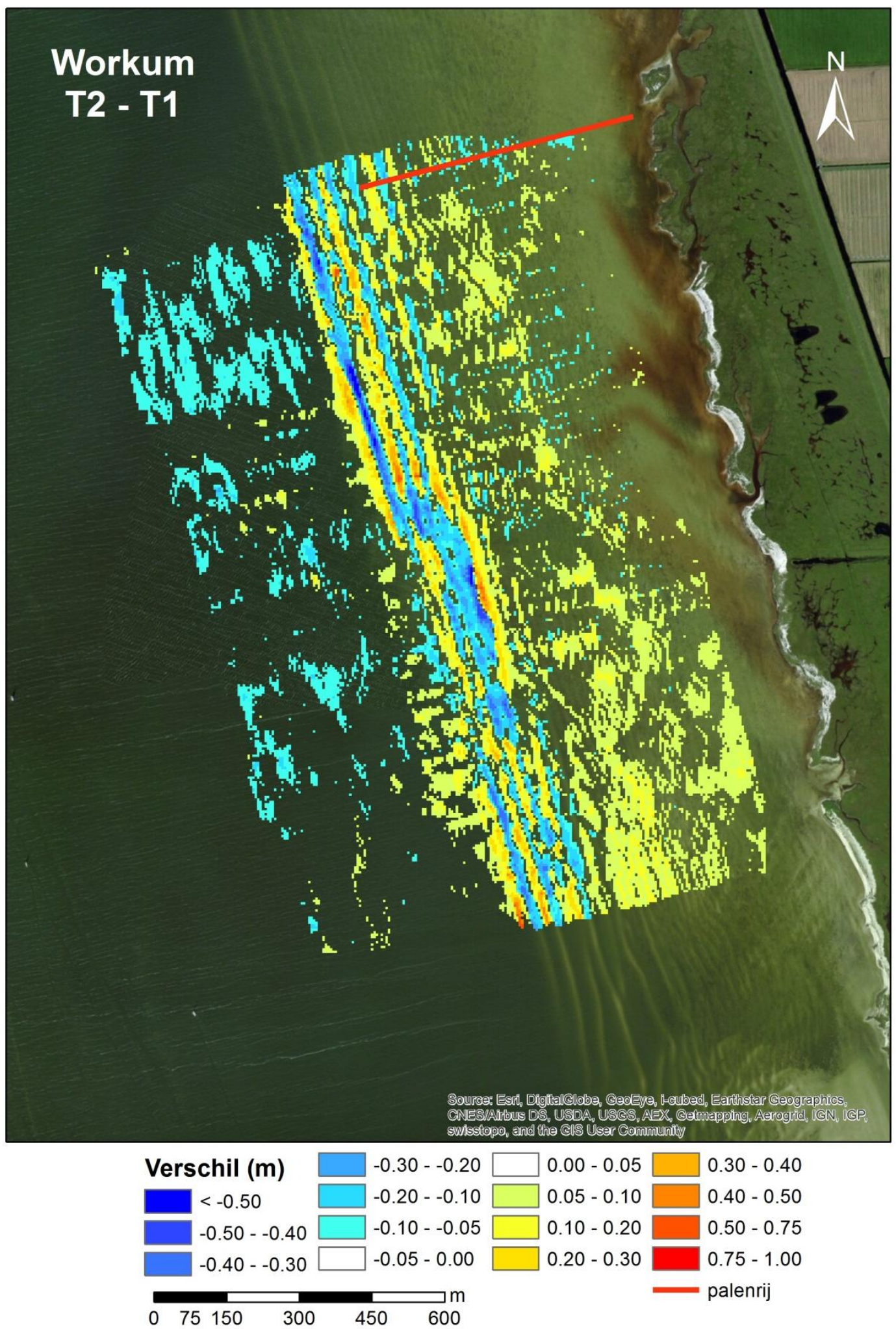

Figuur 3.16 Verschilplot van de bathymetrie tussen de T1 en T2 opname. Gele en rode kleuren geven sedimentatie weer, blauwe kleuren geven erosie weer. 


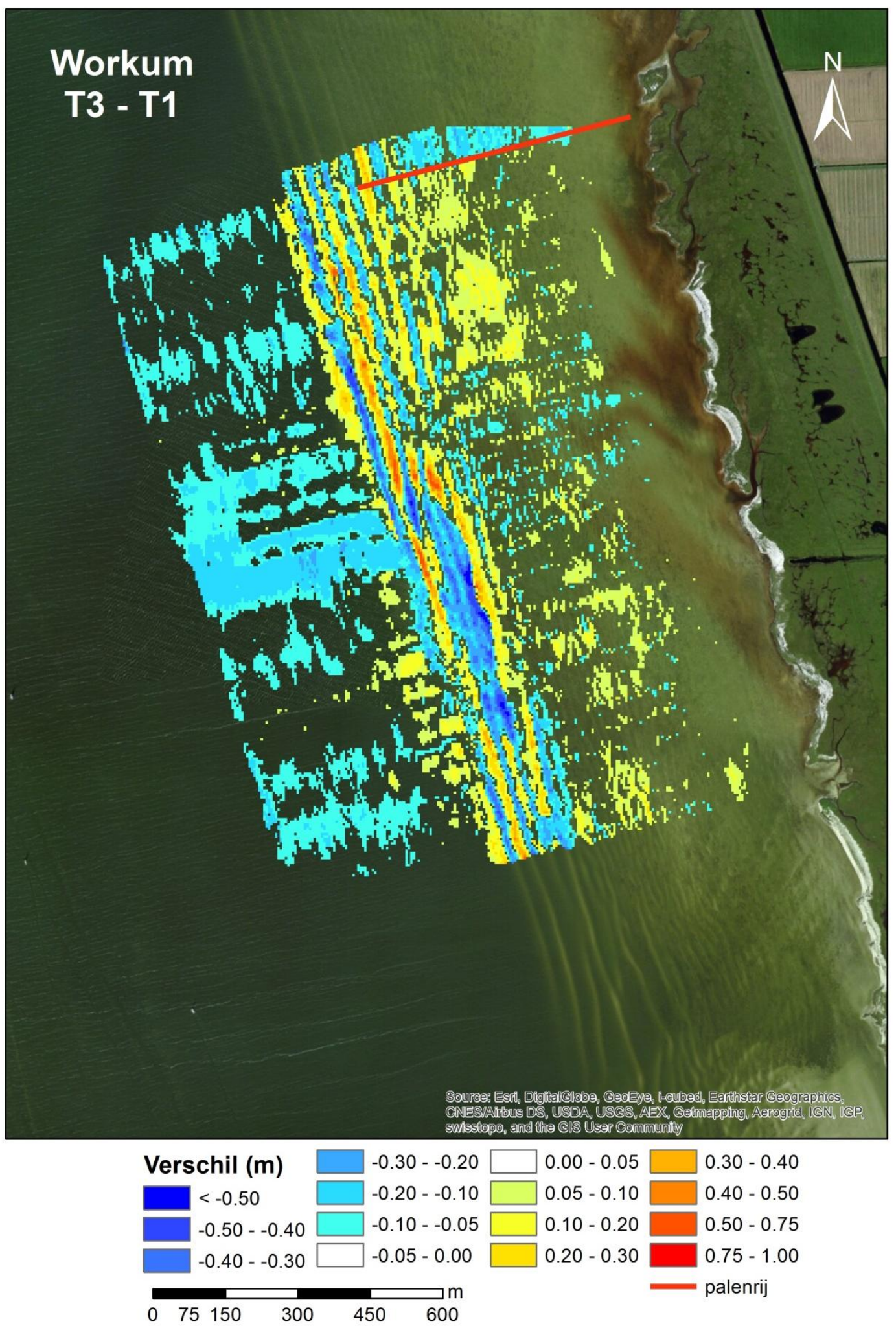

Figuur 3.17 Verschilplot van de bathymetrie tussen de T1 en T3 opname. Gele en rode kleuren geven sedimentatie weer, blauwe kleuren geven erosie weer. 


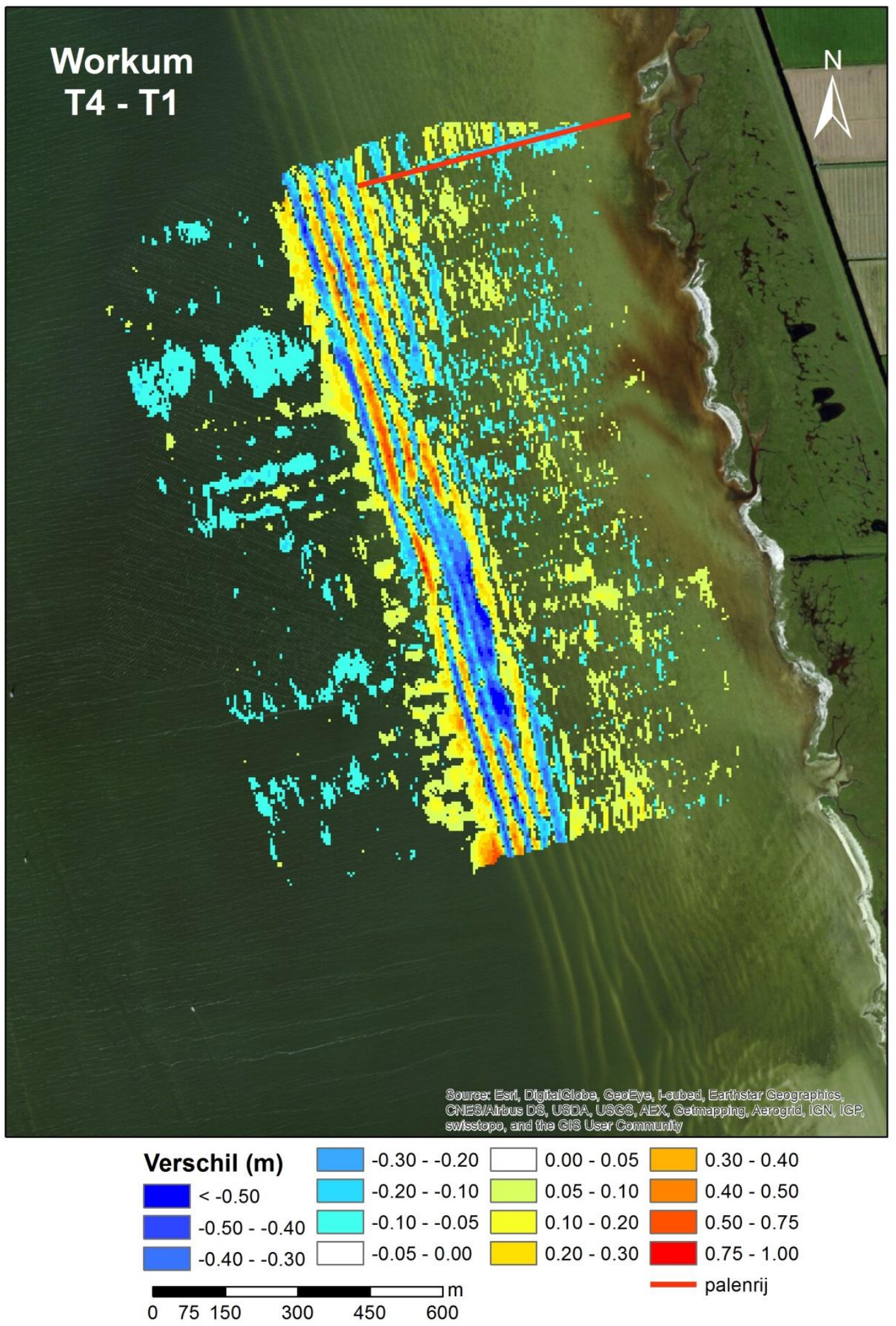

Figuur 3.18 Verschilplot van de bathymetrie tussen de T1 en T4 opname. Gele en rode kleuren geven sedimentatie weer, blauwe kleuren geven erosie weer. 


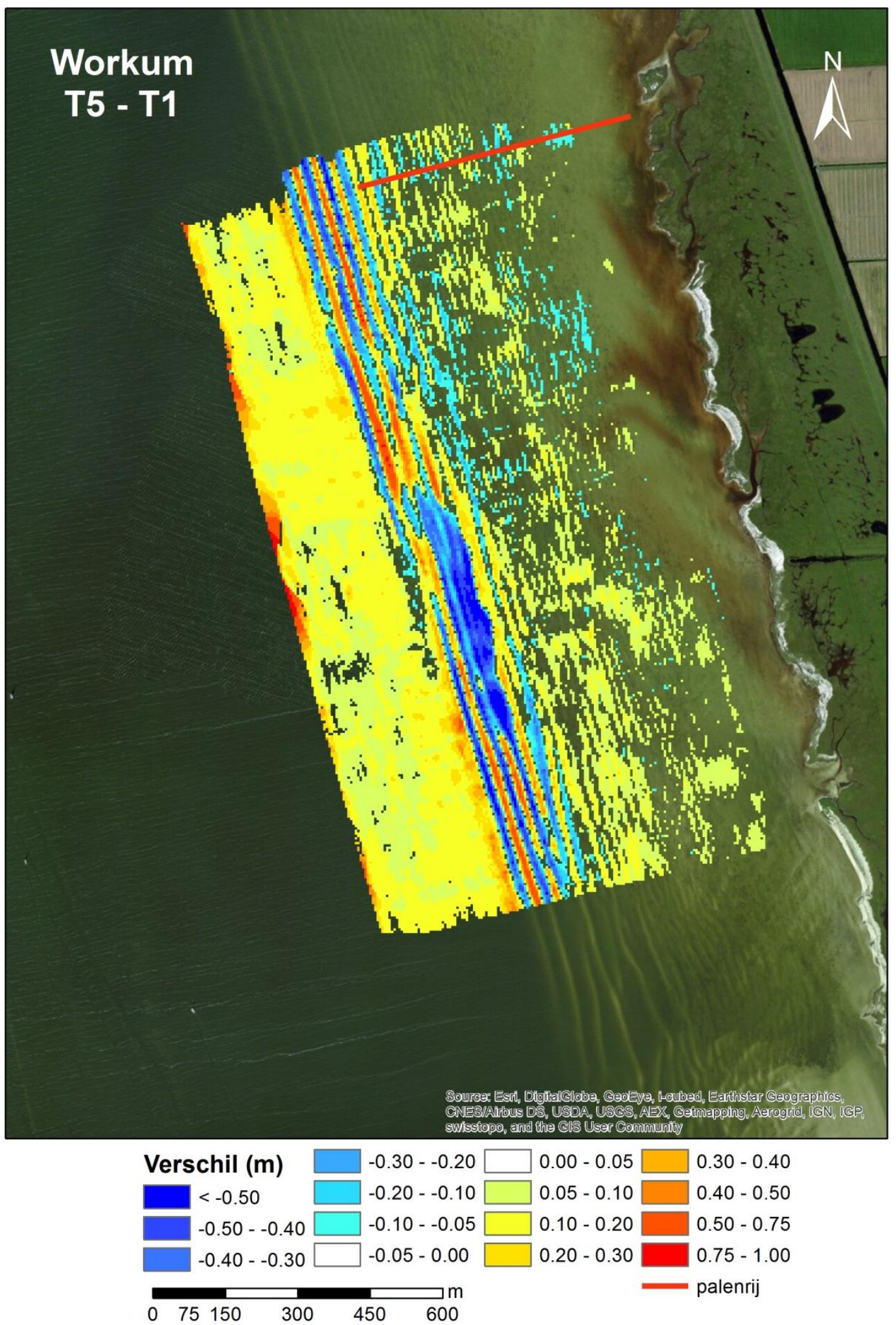

Figuur 3.19 Verschilplot van de bathymetrie tussen de T1 en T5 opname. Gele en rode kleuren geven sedimentatie weer, blauwe kleuren geven erosie weer. 


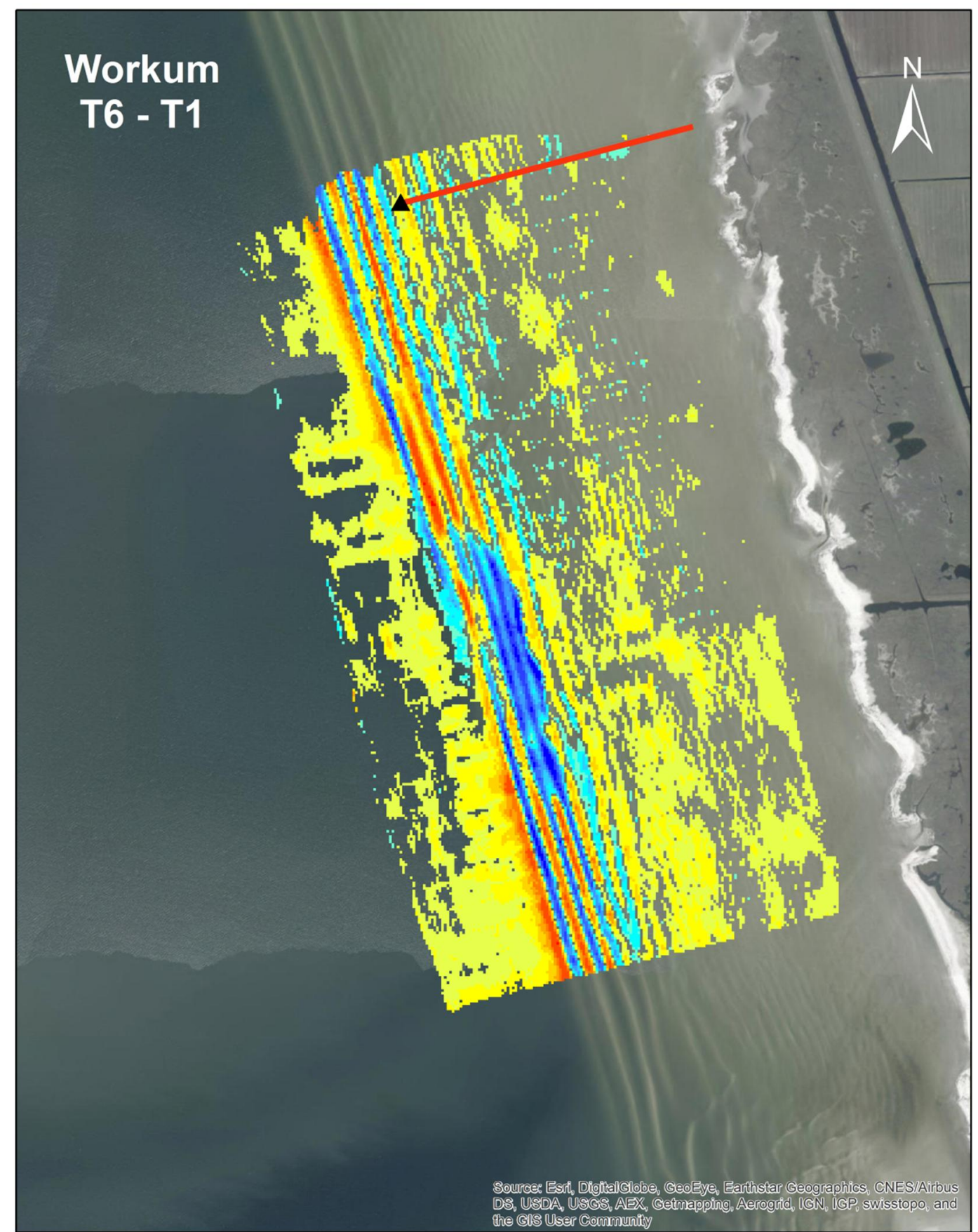

\begin{tabular}{|c|c|c|c|}
\hline Verschil (m) & $-0.30--0.20$ & $0.00-0.05$ & $0.30-0.40$ \\
\hline$<-0.50$ & $-0.20--0.10$ & $0.05-0.10$ & $0.40-0.50$ \\
\hline$-0.50--0.40$ & $-0.10--0.05$ & $0.10-0.20$ & $0.50-0.75$ \\
\hline$-0.40--0.30$ & $-0.05-0.00$ & $0.20-0.30$ & $0.75-1.00$ \\
\hline
\end{tabular}

Figuur 3.20 Verschilplot van de bathymetrie tussen de T1 en T6 opname. Gele en rode kleuren geven sedimentatie weer, blauwe kleuren geven erosie weer. 


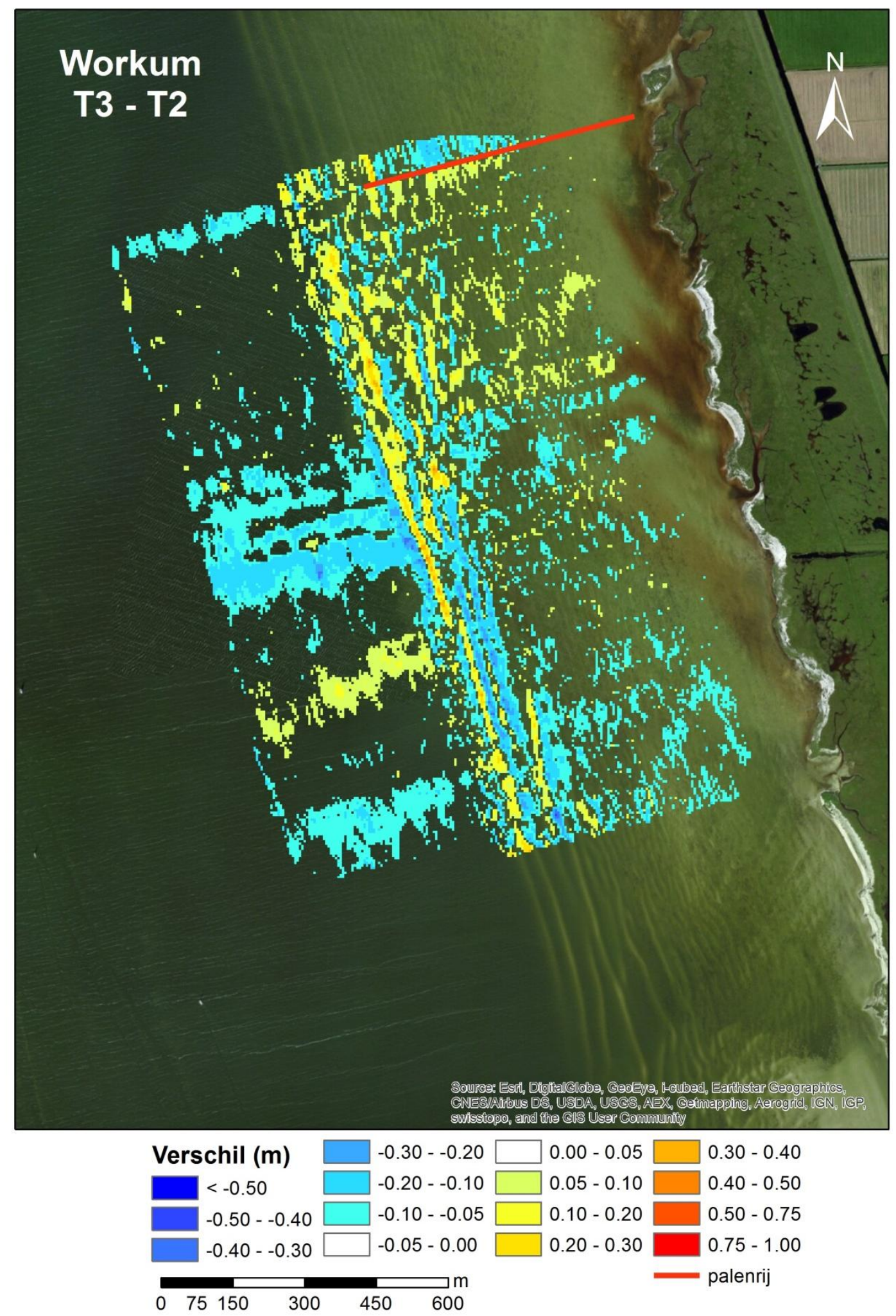

Figuur 3.21 Verschilplot van de bathymetrie tussen de T2 en T3 opname. Gele en rode kleuren geven sedimentatie weer, blauwe kleuren geven erosie weer. 


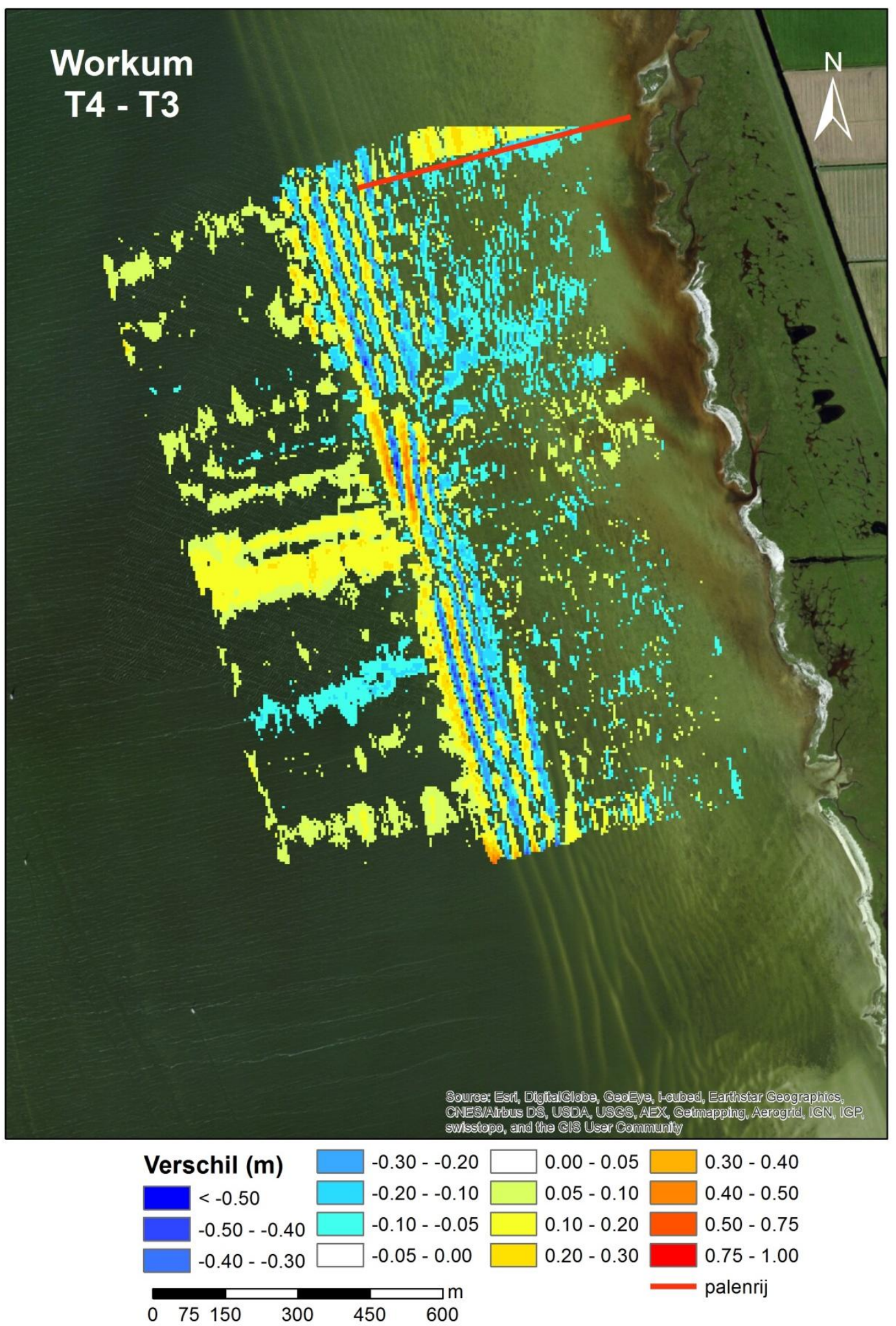

Figuur 3.22 Verschilplot van de bathymetrie tussen de T3 en T4 opname. Gele en rode kleuren geven sedimentatie weer, blauwe kleuren geven erosie weer. 


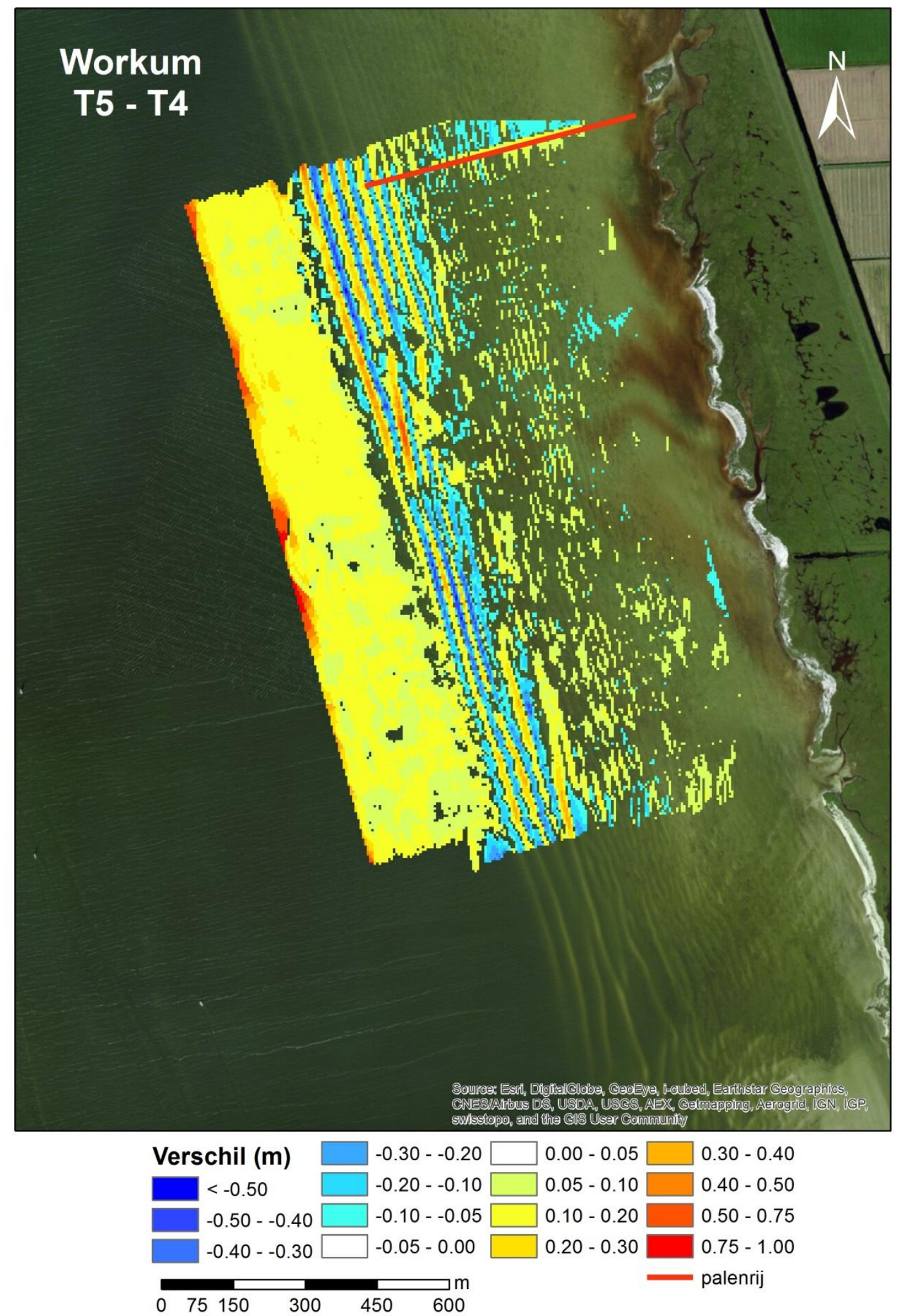

Figuur 3.23 Verschilplot van de bathymetrie tussen de T4 en T5 opname. Gele en rode kleuren geven sedimentatie weer, blauwe kleuren geven erosie weer. 


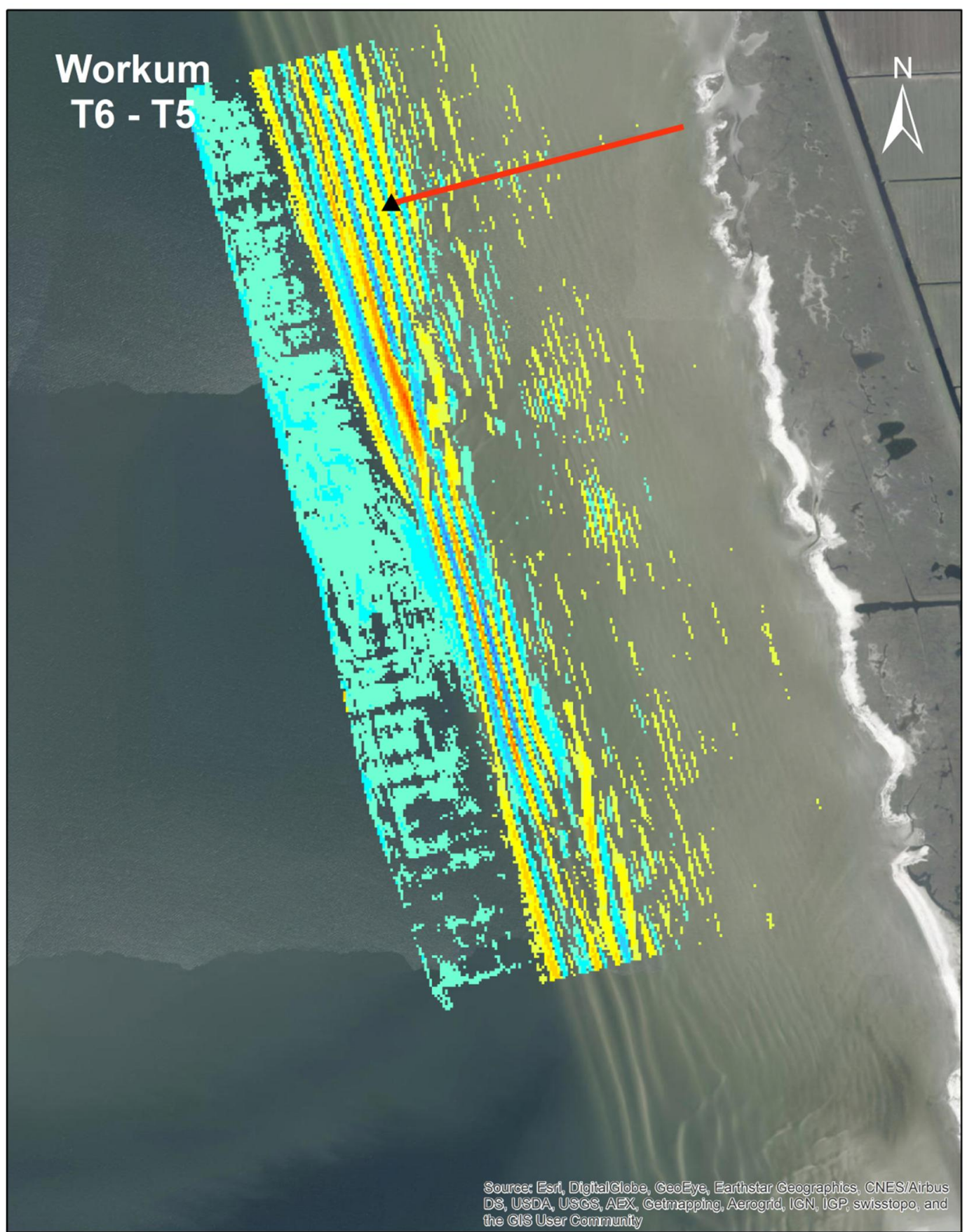

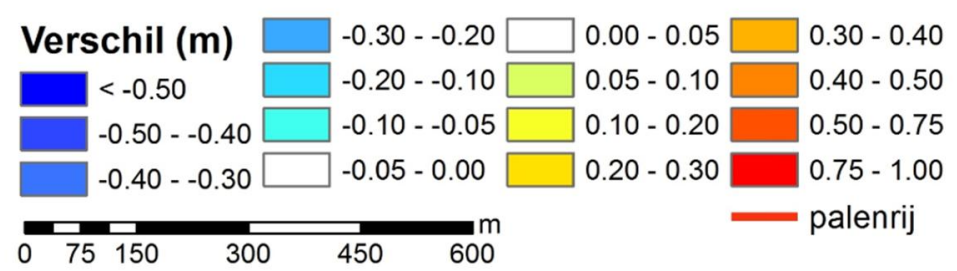

Figuur 3.24 Verschilplot van de bathymetrie tussen de T5 en T6 opname. Gele en rode kleuren geven sedimentatie weer, blauwe kleuren geven erosie weer. 


\subsection{Oudemirdum}

Bij Oudemirdum bestaat de morfologische monitoring uit de uitgangssituatie (T0), de situatie direct nadat de zandmotor is aangelegd (T1), de situatie een half jaar na de aanleg (T2) en een jaar na de aanleg (T3). Figuur 3.27 tot en met Figuur 3.39 tonen de bathymetrie, verschilkaarten en dwarsprofielen over de suppletie. Om erosie en sedimentatie langs de suppletie goed in beeld te brengen, zijn profielen loodrecht over het suppletielichaam getrokken.

Het gebied bij Oudemirdum is vergelijkbaar met dat bij Workum: de vooroever bestaat uit een ondiepte van ongeveer 600 meter breed, waarna een steil talud volgt met dieptes richting de drie meter. Op de vooroever zijn aan de IJsselmeerzijde brede zandruggen gevormd, die smaller en lager worden richting de kust. In Oudemirdum zijn er echter ook zandlichamen aanwezig met een noordoost - zuidwest oriëntatie. De suppletie bestaat uit een ondiepe haak die loopt tot in het gebied met de zandruggen.

Het verschilplot tussen de T0 opname en de T1 opname toont de haak met een dikte van maximaal $70 \mathrm{~cm}$ (Figuur 3.32). In het gebied met de brede zandruggen hebben zich ook veranderingen voorgedaan in de periode tussen de T0 en T1 opname. Dit duidt op dynamiek in het gebied met de zandruggen. De zandruggen zijn ook hier door de suppletie verstoord en bedekt.

Uit de T2 meting van november 2013 blijkt dat de suppletie is afgevlakt en richting het oosten is bewogen (Figuur 3.29). Dit is ook goed te zien in de verschilplots (Figuur 3.36) en dwarsprofielen langs de suppletie (Error! Reference source not found.; Bijlage A.2.3), waar erosie overheerst ter plaatse van de eerdere positie van de suppletie en sedimentatie aan de oostkant van de eerdere positie. Het gebied met sedimentatie is ongeveer 40 meter breed. Aan de westzijde van de haak is geen sedimentatie zichtbaar.

In tijdstap T3 is een verdere afvlakking van de suppletie te zien, waarbij minder erosie en sedimentatie plaatsvindt dan tijdens de vorige tijdstap (Figuur 3.39). Het proces zet zich voort tot in tijdstap T4, Gedurende alle tijdstappen vindt een verplaatsing van de kustparallele zandruggen plaats.

Er is bestaat een verschil tussen de hoeveelheid zand die zou zijn gesuppleerd $\left(11.500 \mathrm{~m}^{3}\right)$ en de berekende toename van volume ter plaatse van de suppletie tussen tijdstappen T0 en $\mathrm{T} 1\left(12.700 \mathrm{~m}^{3}\right)$. Het afvlakken van de suppletie gedurende tijdstappen is duidelijk herkenbaar in het berekende volume van de suppletie (Error! Reference source not found.). Het valt op dat het totaalvolume van T2 en T4 beduidend lager is dan dat van T1 en T3. In profielen 3, 4 en 5 is te zien dat er veel dynamiek is in het diepere ingemeten deel. Mogelijk zijn de verschillen in volume hieraan te wijten. In Figuur $3.32 \mathrm{t} / \mathrm{m}$ Error! Reference source not found. zijn enkele randeffecten zichtbaar in het grid. Deze zijn niet meegenomen in de volumeberekeningen voor Oudemirdum 'klein'. 


\section{Volume sediment t.o.v. TO}

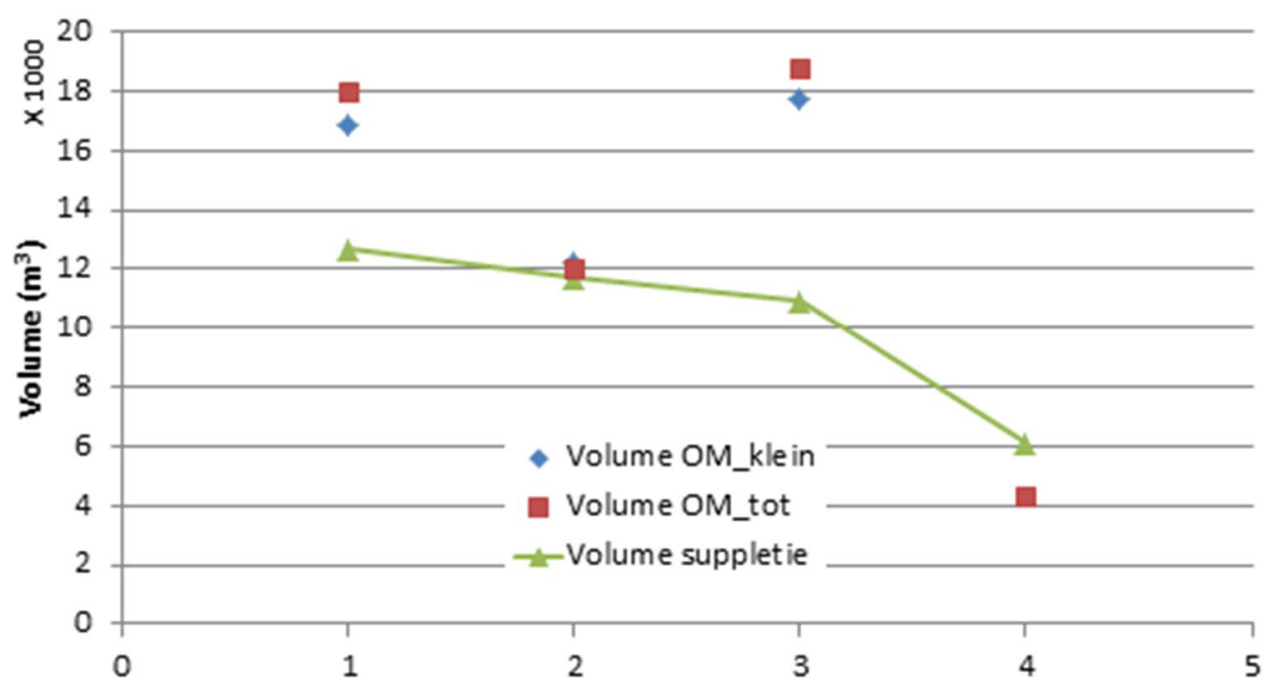

Figuur 3.25 Sedimentvolume voor het gehele gebied en in de suppletie. Er is een duidelijke, vrijwel lineaire trend zichtbaar in de sedimentafname in de suppletie. OM_klein reflecteert de volumeberekeningen zonder randen van het grid, zoals in Figuur 2.3. OM_totaal is de volumeberekening voor het gehele grid.

\section{Profiel 2}

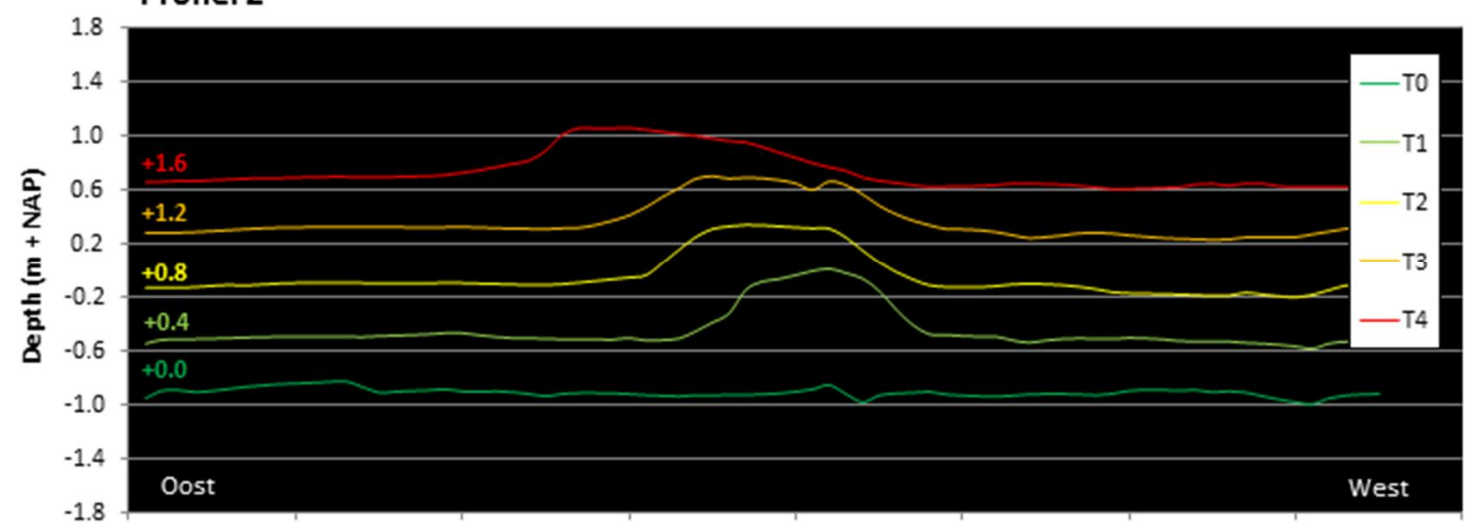

Profiel 3

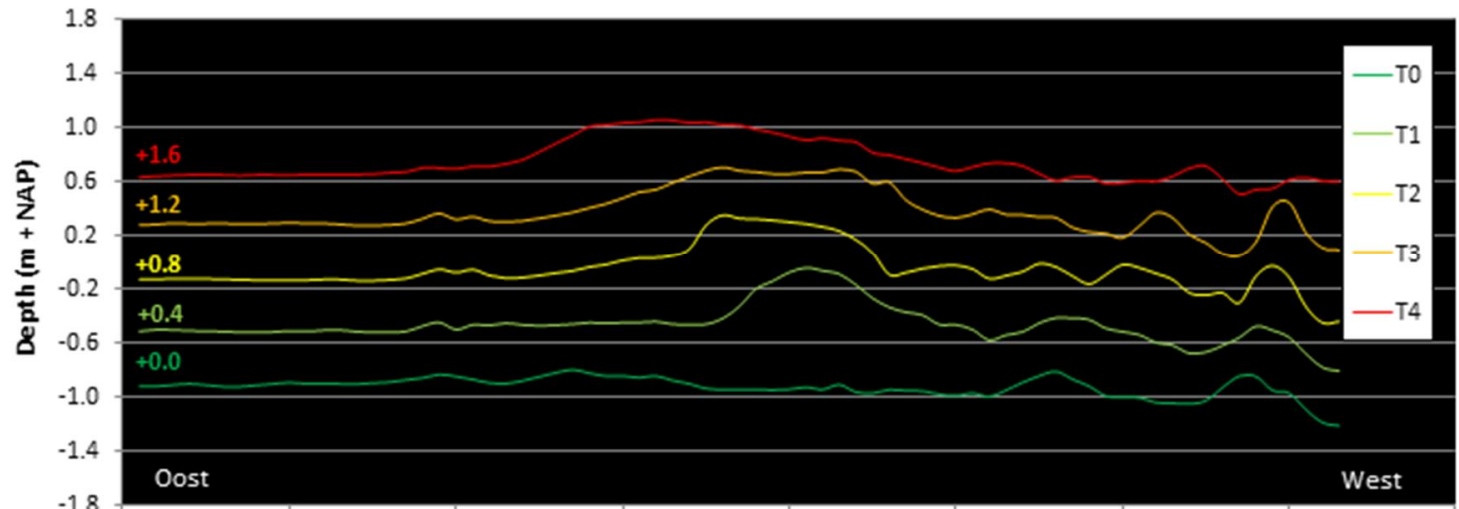

Figuur 3.26 Dwarsprofiel van Noord-Oost naar Zuid-West op twee locaties over de suppletie voor T0 t/m T3. Verplaatsing van sediment uit de suppletie richting het oosten is duidelijk waarneembaar. 


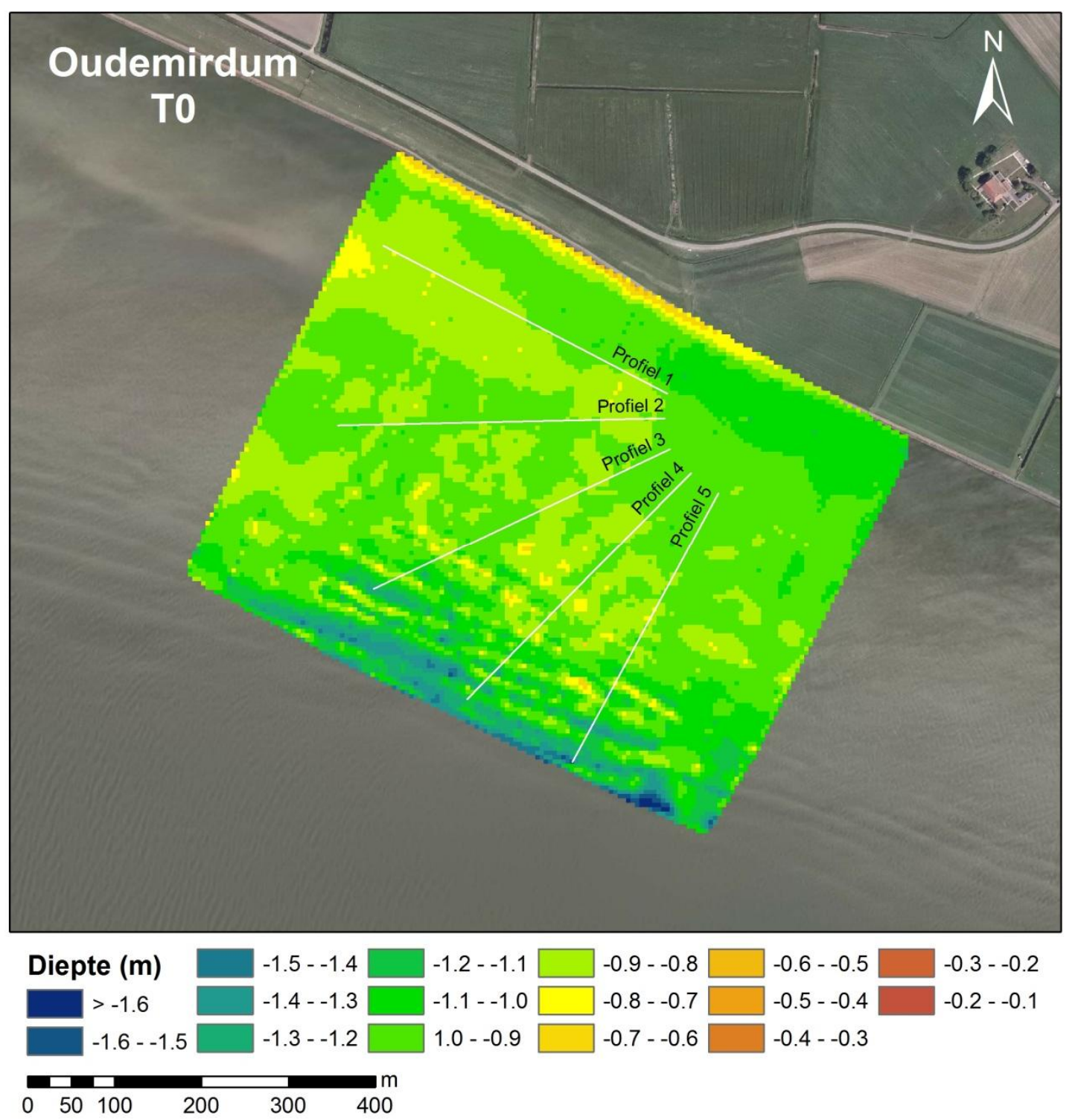

Figuur 3.27 Bathymetrie van de uitgangssituatie van de vooroever voordat de suppletie is aangelegd (T0). De data zijn opgenomen in oktober 2012. 


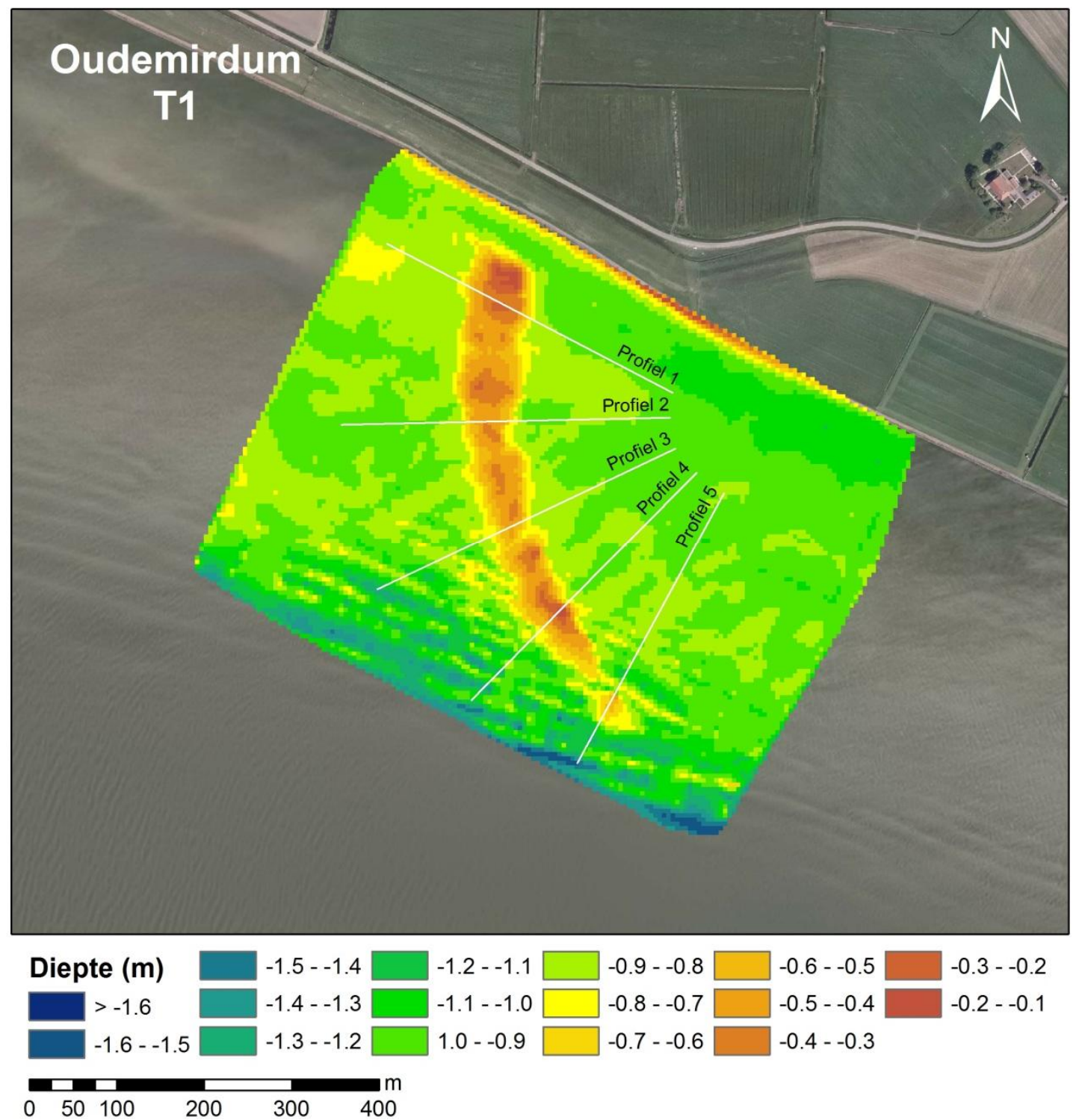

Figuur 3.28 Bathymetrie van de vooroever direct nadat de suppletie is aangelegd (T1). De data zijn opgenomen in april 2013. 


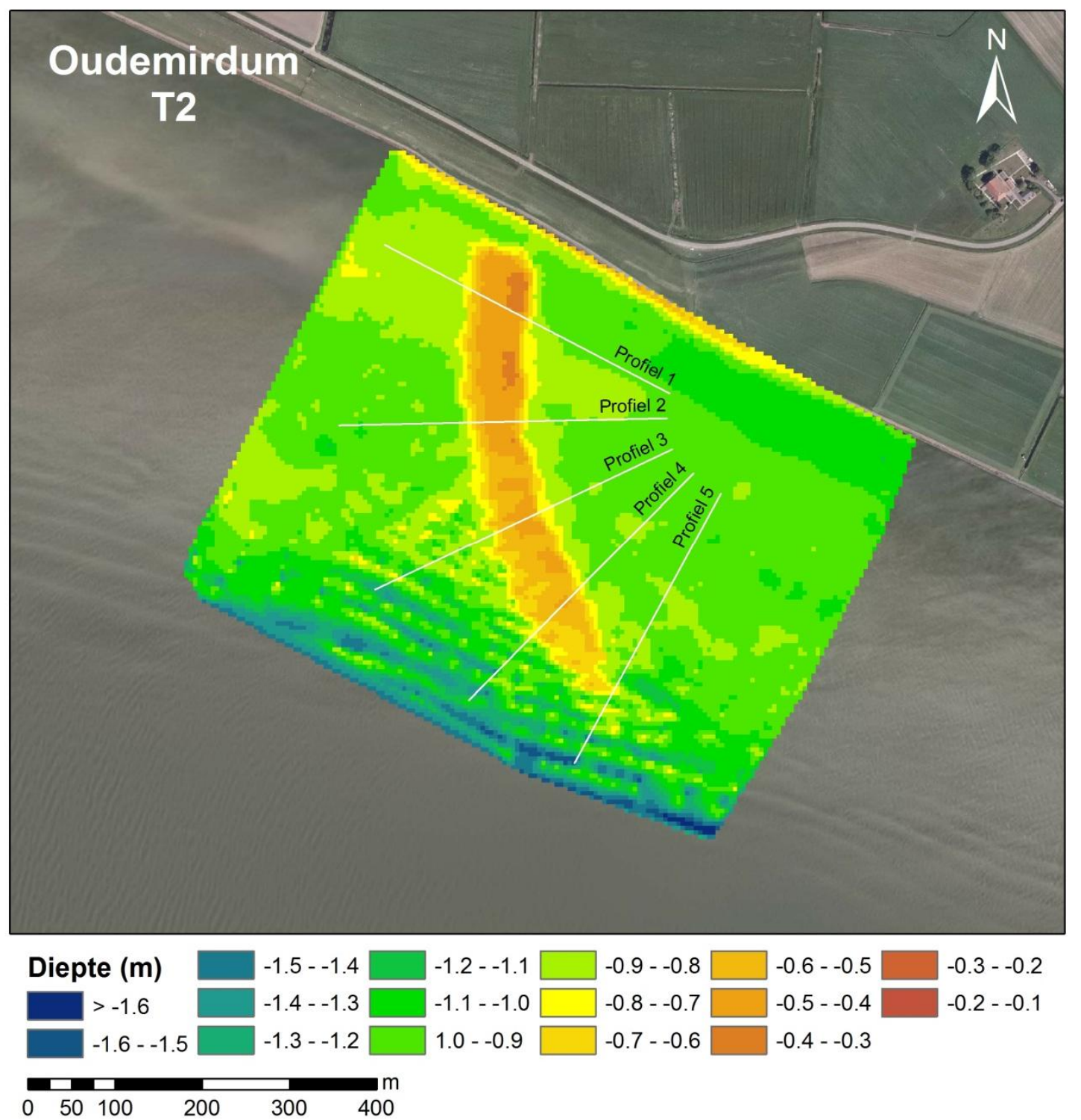

Figuur 3.29 Bathymetrie van de vooroever een half jaar nadat de suppletie is aangelegd (T2). De data zijn opgenomen in november 2013. 


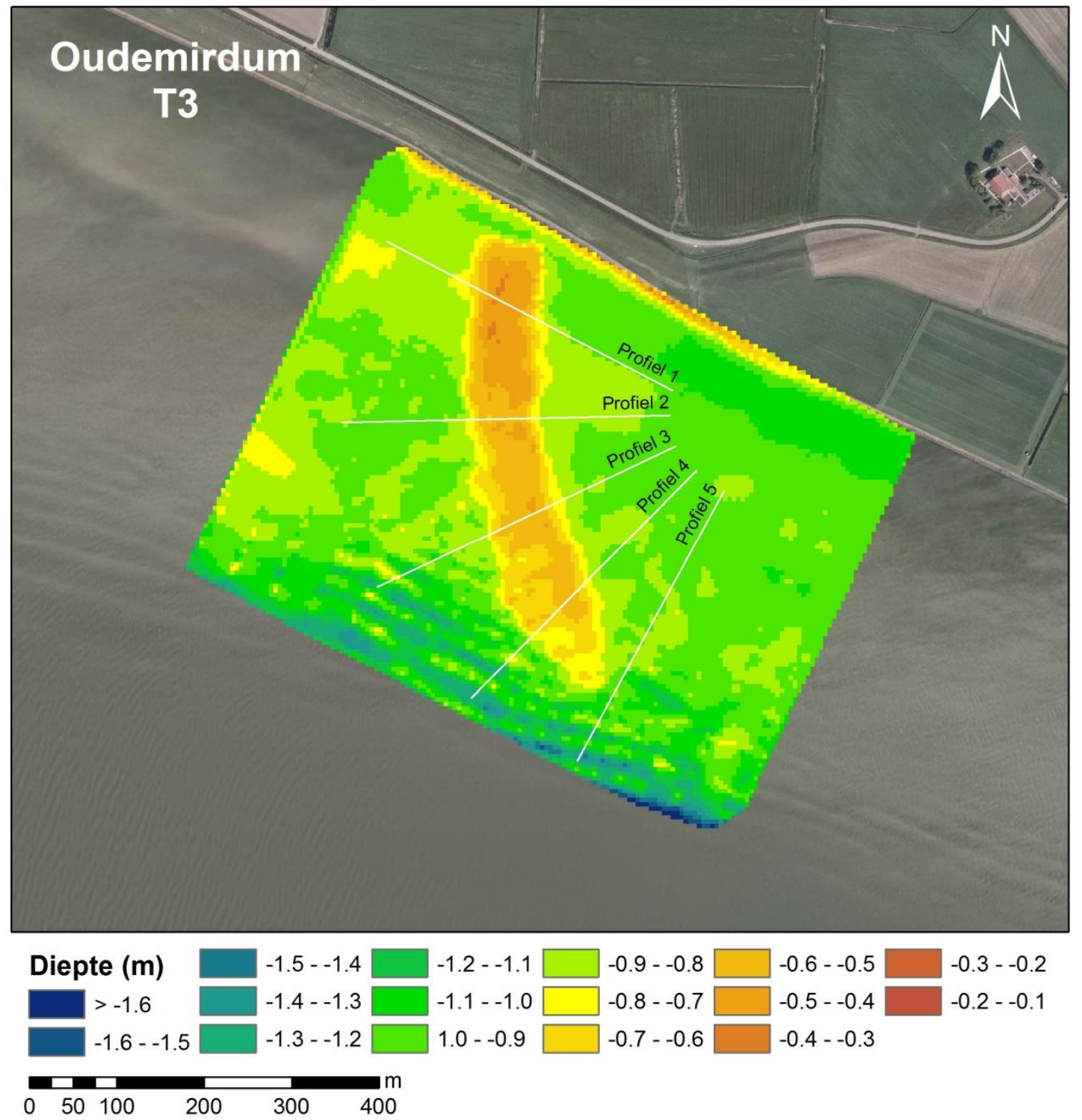

Figuur 3.30 Bathymetrie van de vooroever een jaar nadat de suppletie is aangelegd (T3). De data zijn opgenomen in april 2014. 


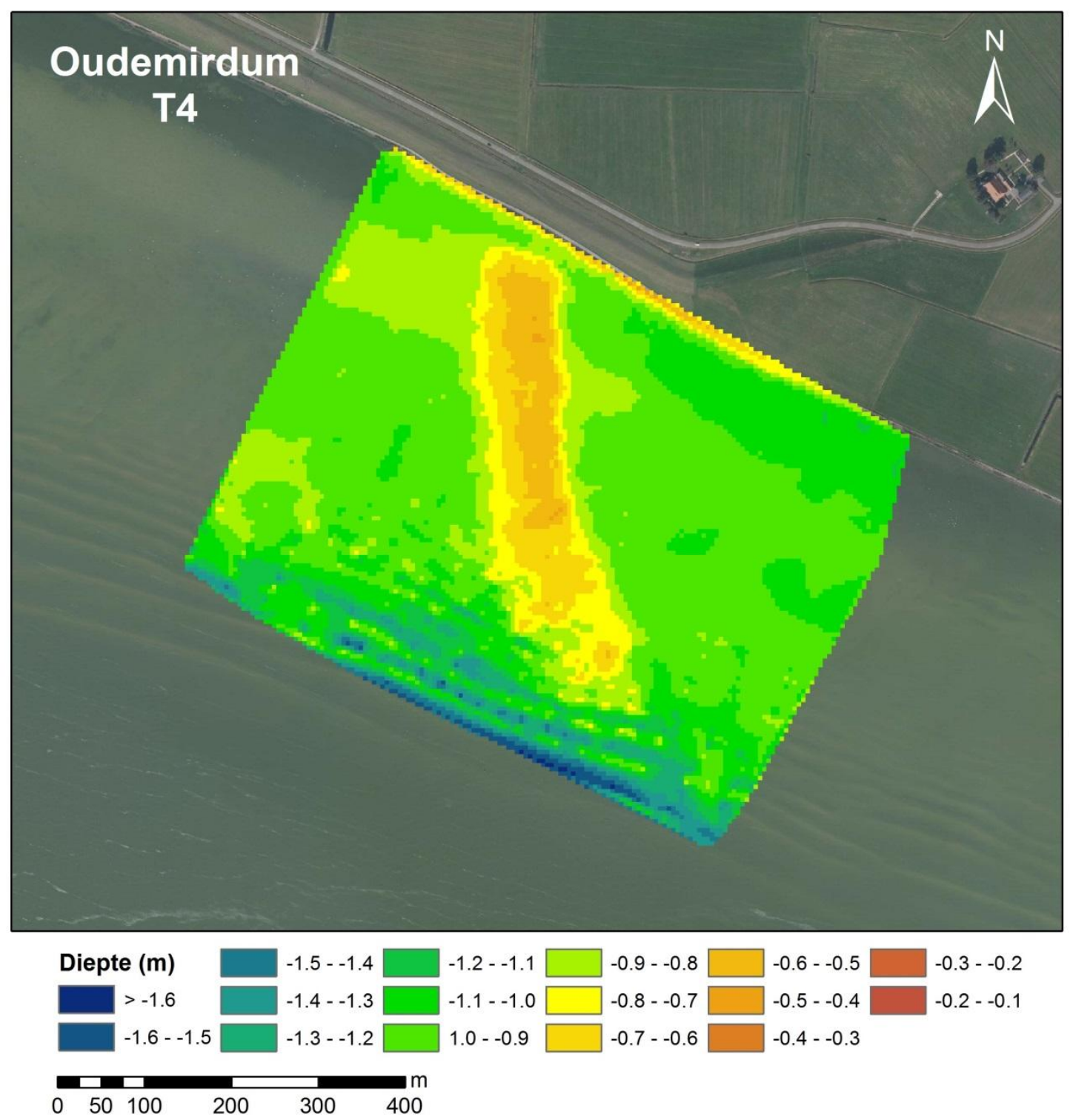

Figuur 3.31 Bathymetrie van de vooroever twee jaar nadat de suppletie is aangelegd (T4). De data zijn opgenomen in mei 2015. 


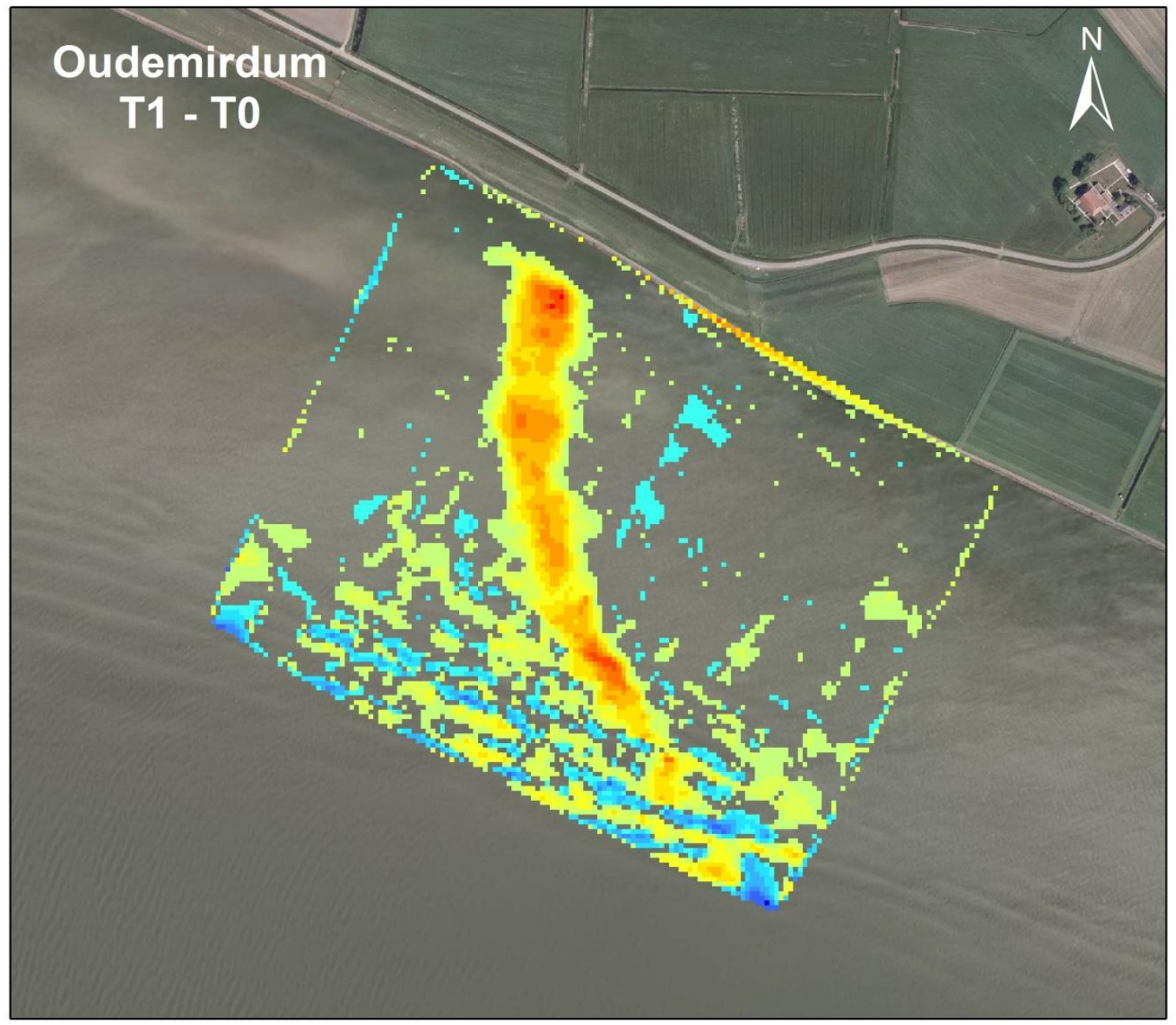

\begin{tabular}{|c|c|c|c|c|}
\hline Verschil (m) & $-0.40--0.30$ & $-0.05-0.00$ & $0.20-0.30$ & $0.60-0.70$ \\
\hline$>0.60$ & $-0.30--0.20$ & $0.00-0.05$ & $0.30-0.40$ & $0.70-0.80$ \\
\hline$-0.60-0.50$ & $-0.20--0.10$ & $0.05-0.10$ & $0.40-0.50$ & $>0.80$ \\
\hline$-0.50--0.40$ & $-0.10--0.05$ & $0.10-0.20$ & $0.50-0.60$ & \\
\hline $100 \quad 200$ & 300 & & & \\
\hline
\end{tabular}

Figuur 3.32 Verschilplot van de bathymetrie tussen de TO en T1 opname. Gele en rode kleuren geven sedimentatie weer, blauwe kleuren geven erosie weer. 


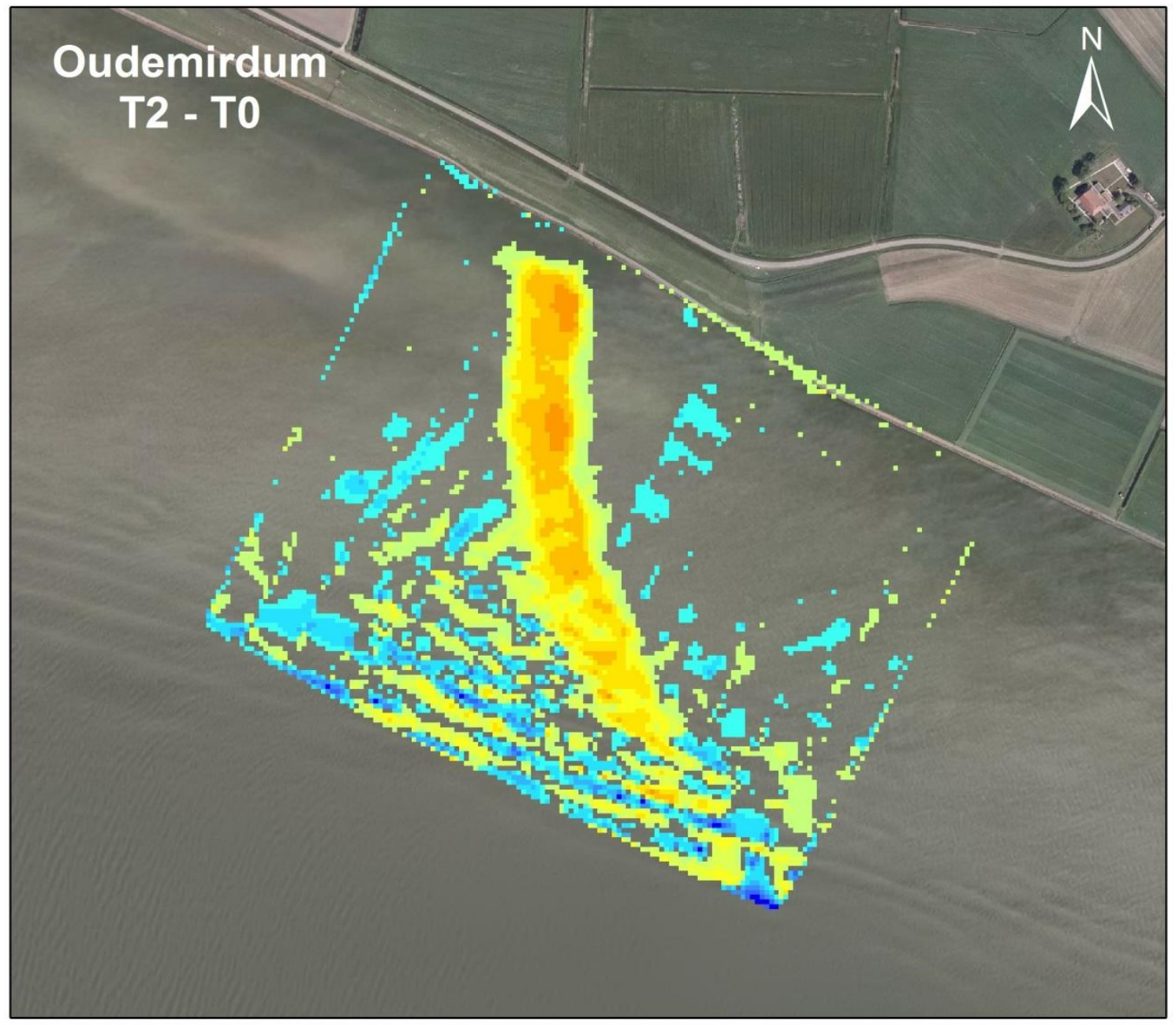

\begin{tabular}{|c|c|c|c|c|}
\hline Verschil (m) & $-0.40--0.30$ & $-0.05-0.00$ & $0.20-0.30$ & $0.60-0.70$ \\
\hline$>0.60$ & $-0.30--0.20$ & $0.00-0.05$ & $0.30-0.40$ & $0.70-0.80$ \\
\hline$-0.60-0.50$ & $-0.20--0.10$ & $0.05-0.10$ & $0.40-0.50$ & $>0.80$ \\
\hline$-0.50--0.40$ & $-0.10--0.05$ & $0.10-0.20$ & $0.50-0.60$ & \\
\hline 100 & 300 & & & \\
\hline
\end{tabular}

Figuur 3.33 Verschilplot van de bathymetrie tussen de T0 en T2 opname. Gele en rode kleuren geven sedimentatie weer, blauwe kleuren geven erosie weer. 


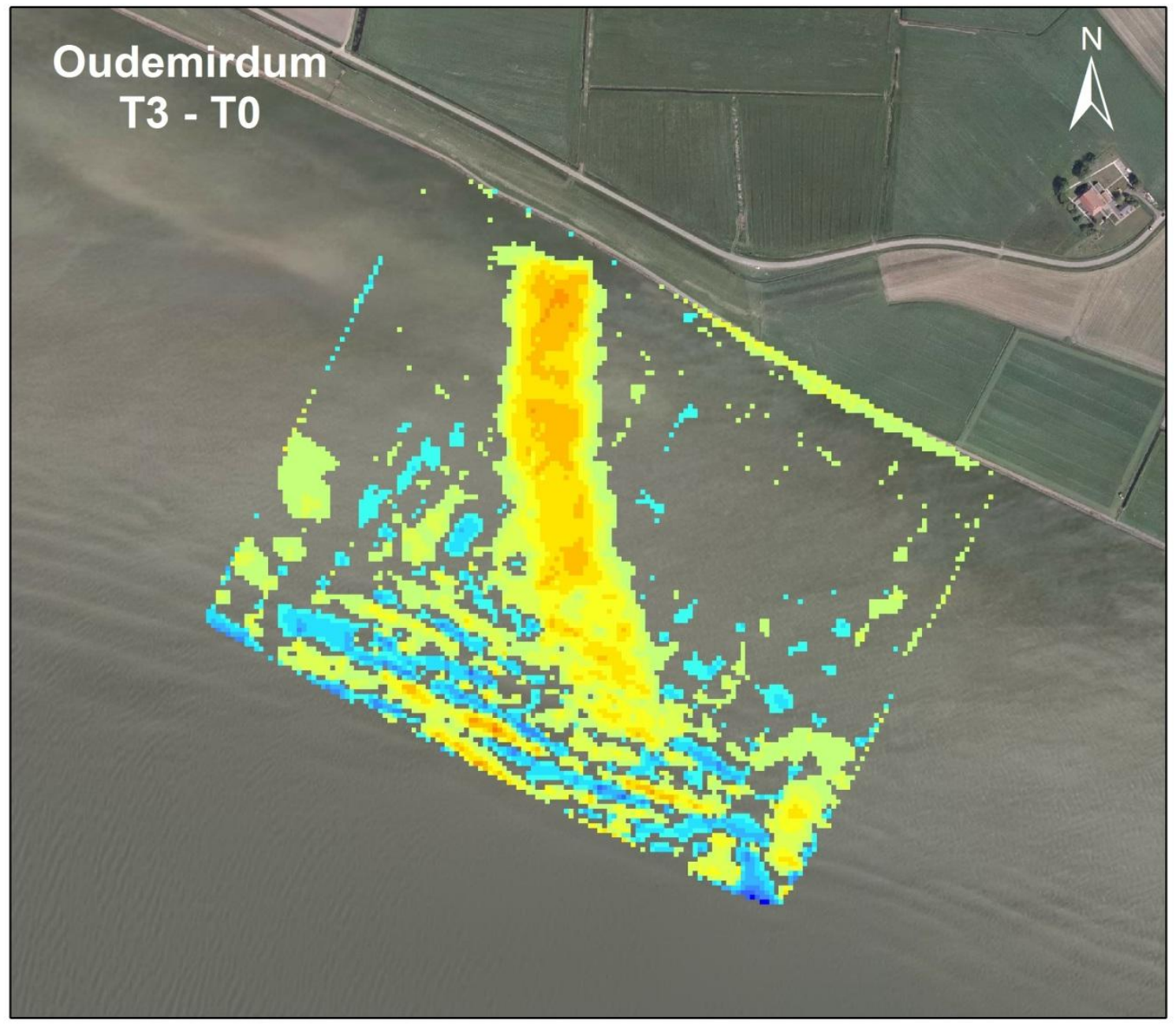

\begin{tabular}{|c|c|c|c|c|}
\hline Verschil (m) & $-0.40--0.30$ & $-0.05-0.00$ & $0.20-0.30$ & $0.60-0.70$ \\
\hline$>0.60$ & $-0.30--0.20$ & $0.00-0.05$ & $0.30-0.40$ & $0.70-0.80$ \\
\hline$-0.60-0.50$ & $-0.20--0.10$ & $0.05-0.10$ & $0.40-0.50$ & $>0.80$ \\
\hline$-0.50--0.40$ & $-0.10--0.05$ & $0.10-0.20$ & $0.50-0.60$ & \\
\hline 100 & 300 & & & \\
\hline
\end{tabular}

Figuur 3.34 Verschilplot van de bathymetrie tussen de TO en T3 opname. Gele en rode kleuren geven sedimentatie weer, blauwe kleuren geven erosie weer. 


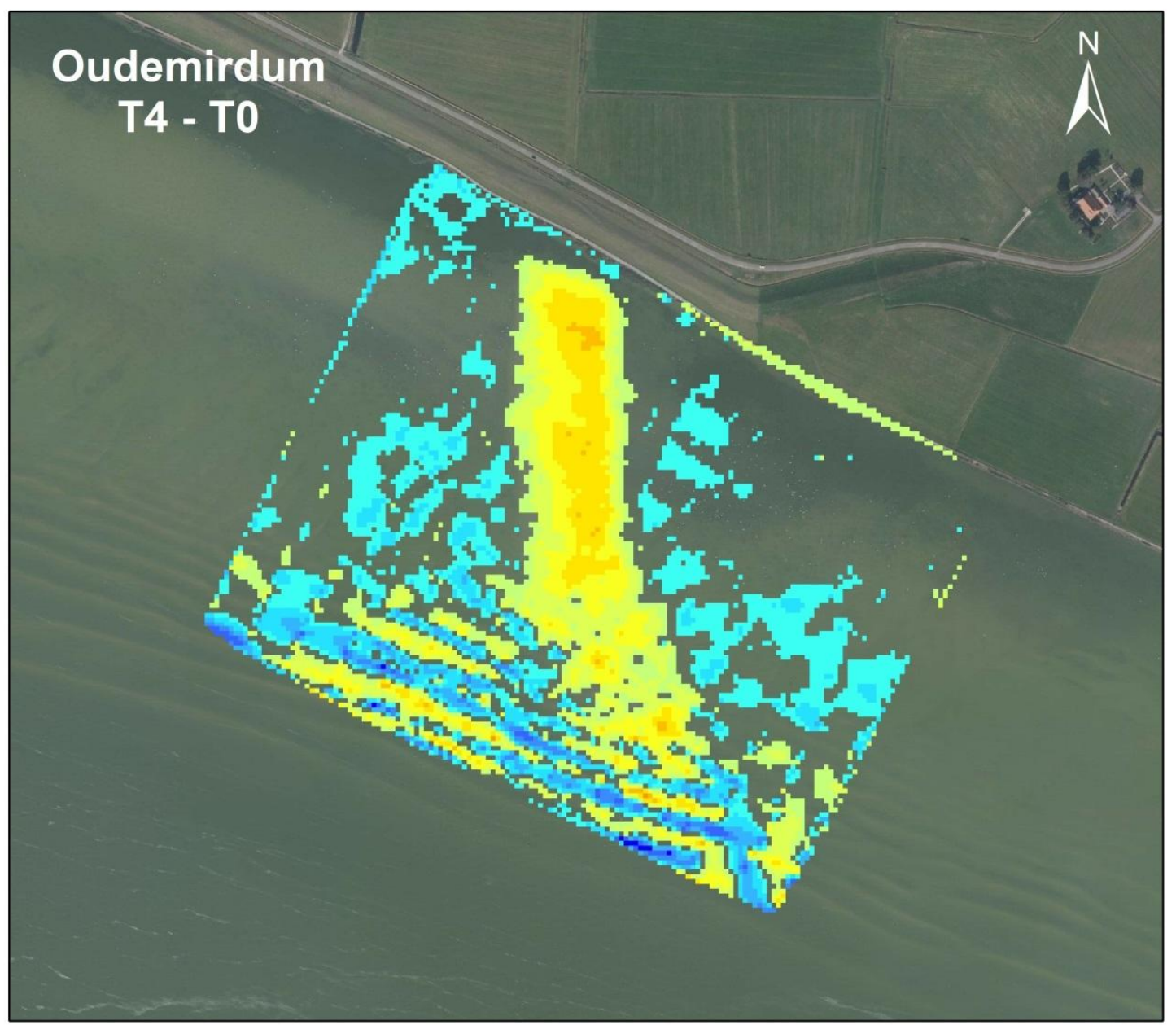

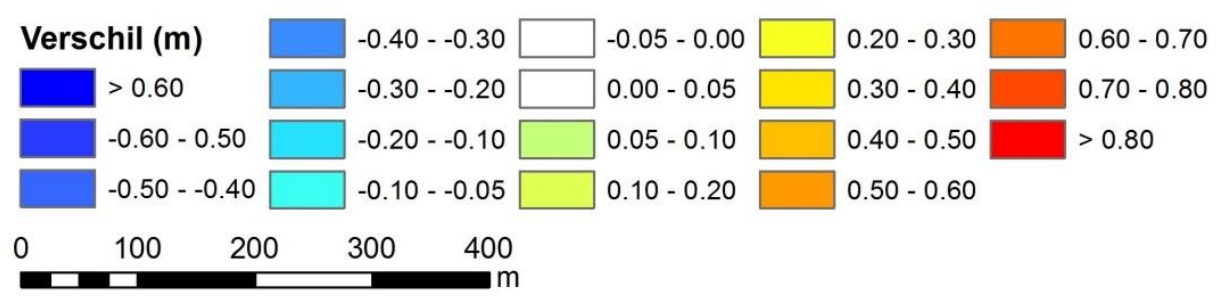

Figuur 3.35 Verschilplot van de bathymetrie tussen de TO en T4 opname. Gele en rode kleuren geven sedimentatie weer, blauwe kleuren geven erosie weer. 


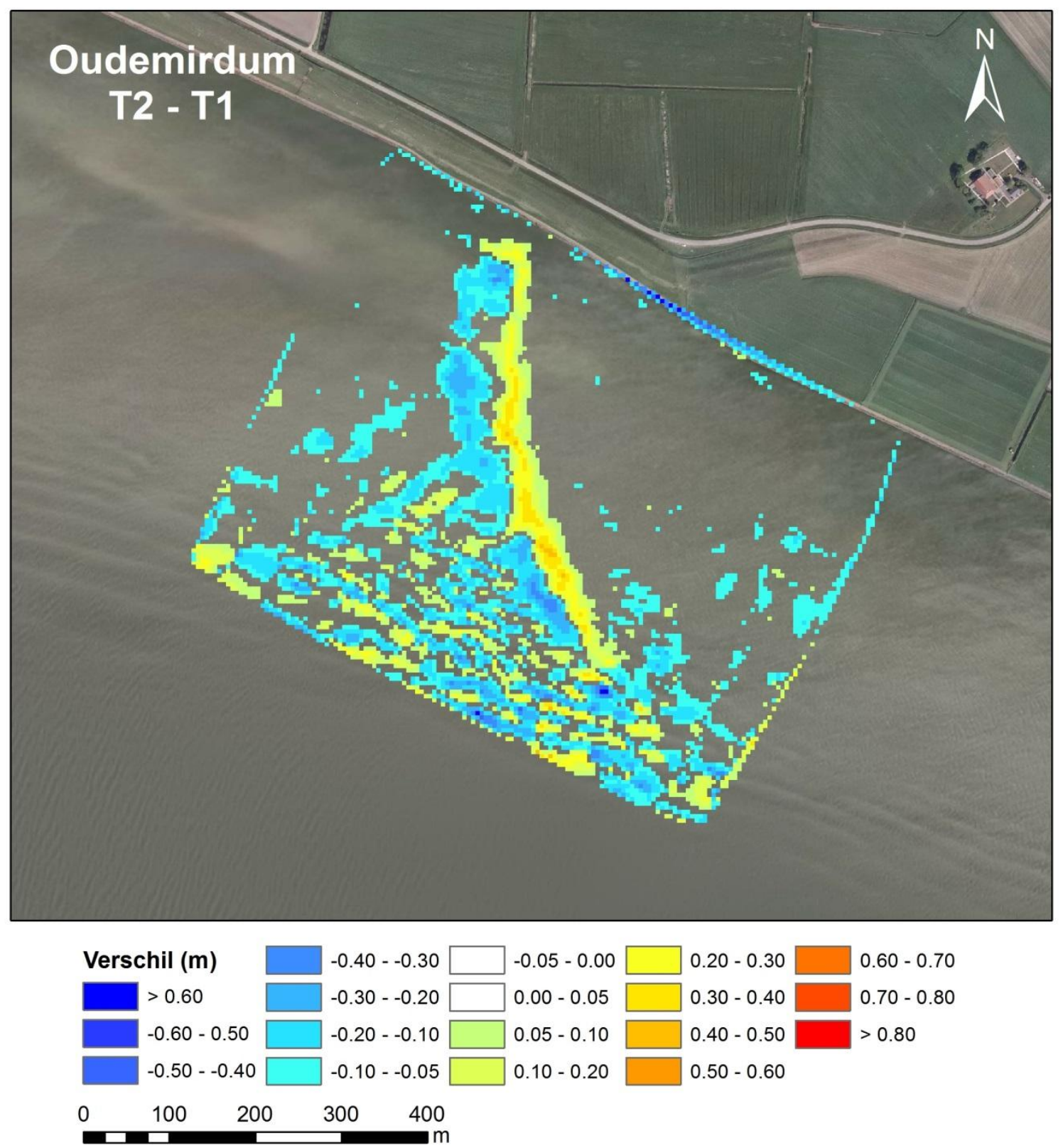

Figuur 3.36 Verschilplot van de bathymetrie tussen de T1 en T2 opname. Gele en rode kleuren geven sedimentatie weer, blauwe kleuren geven erosie weer. 


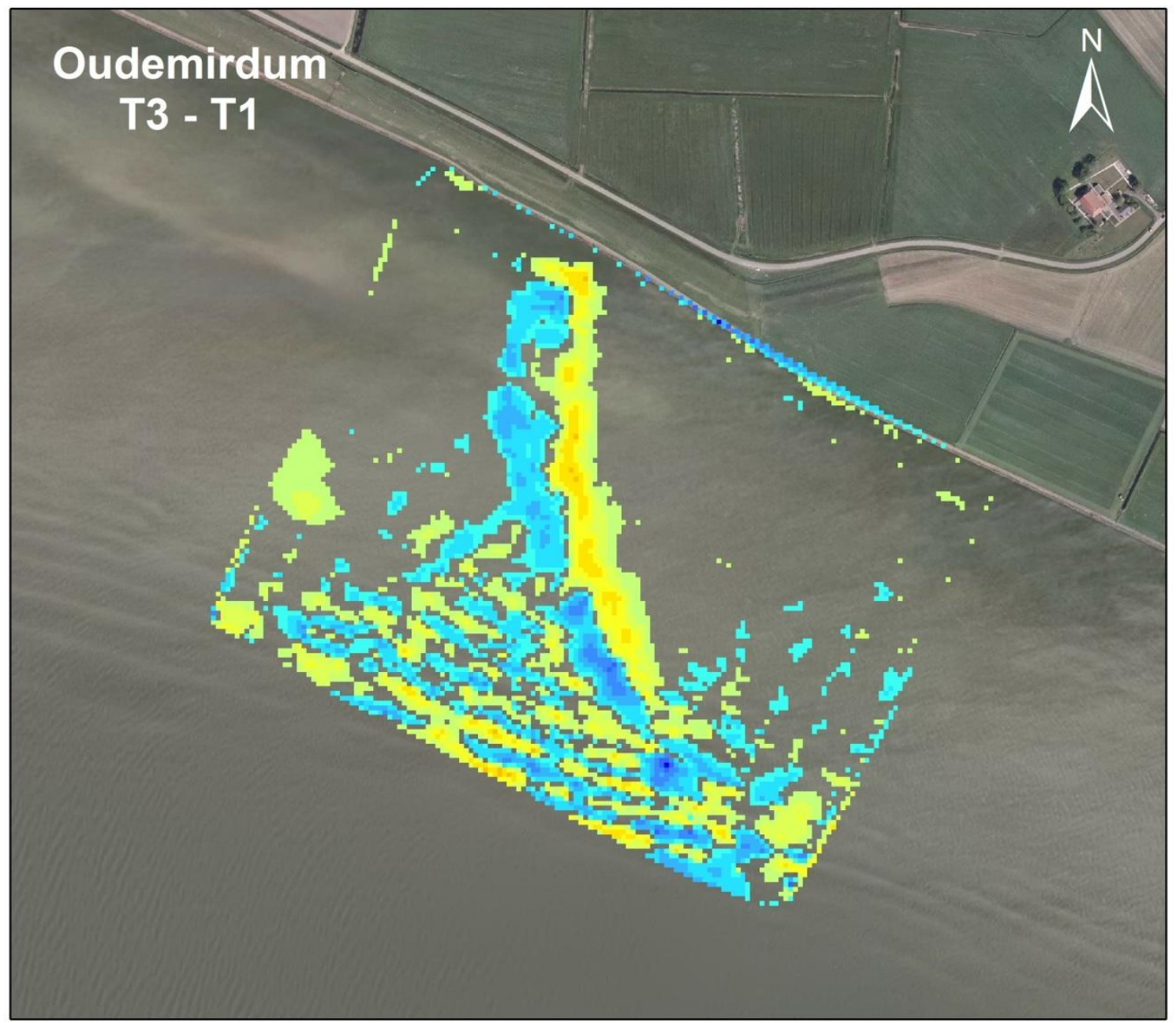

\begin{tabular}{|c|c|c|c|c|}
\hline Verschil (m) & $-0.40--0.30$ & $-0.05-0.00$ & $0.20-0.30$ & $0.60-0.70$ \\
\hline$>0.60$ & $-0.30--0.20$ & $0.00-0.05$ & $0.30-0.40$ & $0.70-0.80$ \\
\hline$-0.60-0.50$ & $-0.20--0.10$ & $0.05-0.10$ & $0.40-0.50$ & $>0.80$ \\
\hline$-0.50--0.40$ & $-0.10--0.05$ & $0.10-0.20$ & $0.50-0.60$ & \\
\hline 100 & 300 & & & \\
\hline
\end{tabular}

Figuur 3.37 Verschilplot van de bathymetrie tussen de T1 en T3 opname. Gele en rode kleuren geven sedimentatie weer, blauwe kleuren geven erosie weer. 


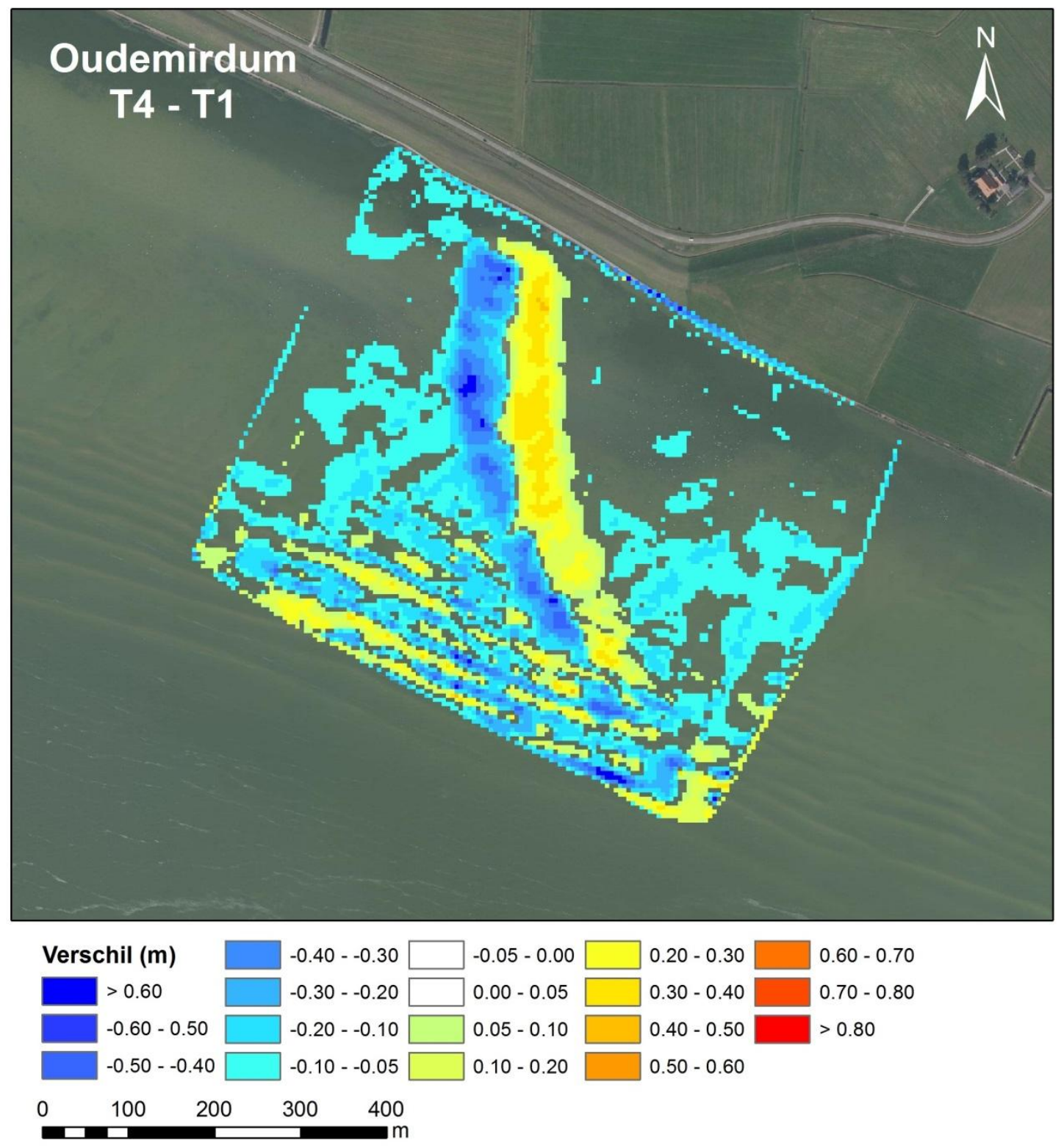

Figuur 3.38 Verschilplot van de bathymetrie tussen de T1 en T4 opname. Gele en rode kleuren geven sedimentatie weer, blauwe kleuren geven erosie weer. 


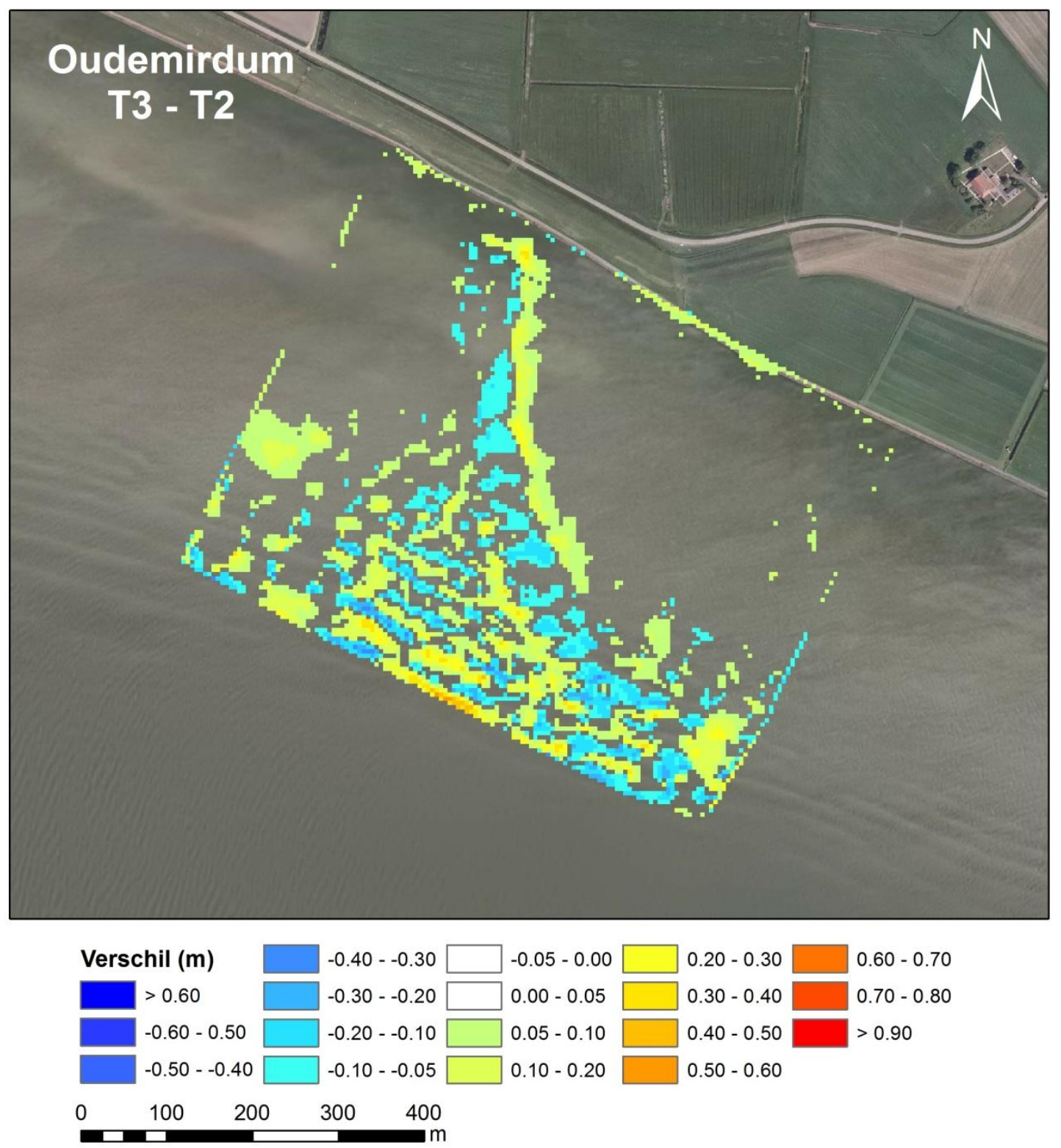

Figuur 3.39 Verschilplot van de bathymetrie tussen de T2 en T3 opname. Gele en rode kleuren geven sedimentatie weer, blauwe kleuren geven erosie weer. 


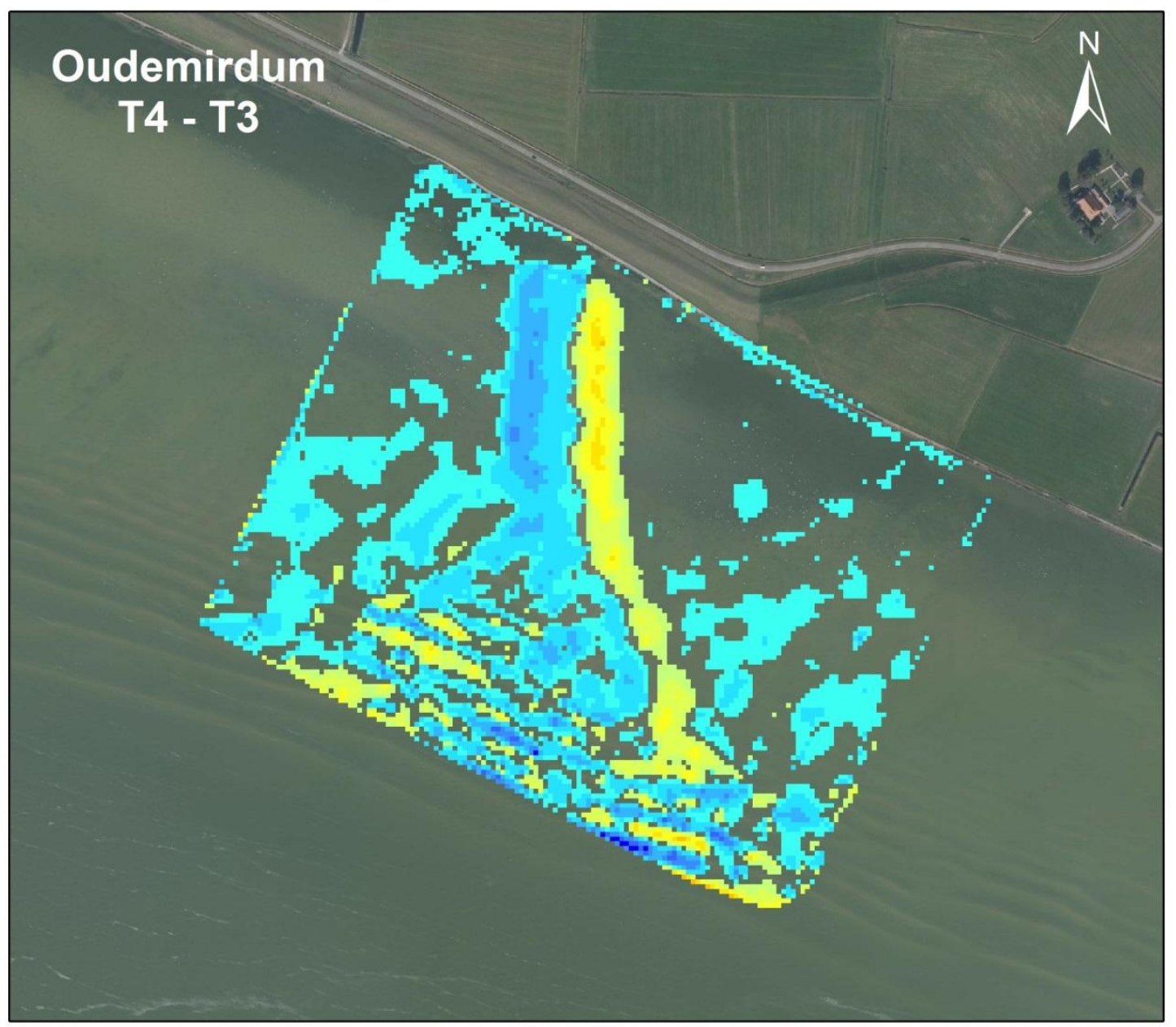

\begin{tabular}{|c|c|c|c|c|}
\hline Verschil (m) & $-0.40--0.30$ & $-0.05-0.00$ & $0.20-0.30$ & $0.60-0.70$ \\
\hline$>0.60$ & $-0.30--0.20$ & $0.00-0.05$ & $0.30-0.40$ & $0.70-0.80$ \\
\hline$-0.60-0.50$ & $-0.20--0.10$ & $0.05-0.10$ & $0.40-0.50$ & $>0.80$ \\
\hline$-0.50--0.40$ & $-0.10--0.05$ & $0.10-0.20$ & $0.50-0.60$ & \\
\hline 100 & 300 & & & \\
\hline
\end{tabular}

Figuur 3.40 Verschilplot van de bathymetrie tussen de T3 en T4 opname. Gele en rode kleuren geven sedimentatie weer, blauwe kleuren geven erosie weer. 


\section{Discussie}

\section{Workum}

Het sedimentvolume dat direct na aanleg van de suppletie bij Workum gemeten is, komt niet overeen met de hoeveelheid zand die hier is aangebracht $\left(\sim 18.000 \mathrm{~m}^{3}\right.$ tegen $\left.\sim 31.000 \mathrm{~m}^{3}\right)$. Dit verschil is waarschijnlijk te wijten een combinatie van factoren: uitspoeling van de fijne fractie; de interpolatie van lijndata naar grid; verschil van zandvolume in de beun en in het water. Bovendien is de suppletie gedurende een periode van enkele maanden aangelegd waarin al een deel van het sediment kan zijn verspreid. Beschreven en berekende trends zijn echter wel representatief en waarneembaar in de bathymetrische kaarten.

$\mathrm{Na}$ vier jaar monitoren is er bij Workum nog iets minder dan de helft van het zand aanwezig op de exacte plek waar de suppletie is aangelegd: $8800 \mathrm{~m}^{3}$ in mei 2015 vs. $18.000 \mathrm{~m}^{3}$ in oktober 2011. Het effect van de suppletie is te zien tot meer dan 200 meter ten noorden ervan in de toegenomen sedimentatie. Ook de afstand waarover de zandruggen van vorm veranderden onder invloed van de suppletie is $\mathbf{2 0 0}$ meter. Deze gegevens laten zien dat het gesuppleerde zand nog duidelijk aanwezig is in het systeem. Het zand is echter dermate verspreid dat het nauwelijks golven dissipeert. Het eefect van de suppletie is in die zin verdwenen. Naast veranderingen van sedimentvolume in het gebied van de suppletie, vinden ook significante veranderingen in het sedimentvolume in het gehele studiegebied plaats, in de orde van duizenden kubieke meters. Dit heeft waarschijnlijk te maken met onzekerheden in de volumebepalingen door interpolatie van de meetgegevens.

Het zand uit de suppletie bij Workum lijkt zich voornamelijk her te verdelen in de dynamische zone met de brede zandruggen. In het ondiepe gedeelte richting de kust worden geen eenduidige effecten waargenomen. De verhoogde zandruggen kunnen wel zorgen voor meer golfdissipatie.

De palenrij die is geplaatst om sediment op te vangen lijkt aan de zuidkant niet te leiden tot sedimentatie. Aan de noordzijde van de dam lijkt deze afwisselend tot erosie (T3 en T5) en sedimentatie (T4) te leiden. Vanwege het afwijkende karakter van de meting met erosie lijkt het echter te gaan om een meetfout.

\section{Oudemirdum}

Twee jaar na de aanleg van de suppletie bij Oudemirdum is de haakvorm van de suppletie nog duidelijk aanwezig. Van de $12.700 \mathrm{~m}^{3}$ zand die in de eerste tijdstap is gemeten, ligt nog $6100 \mathrm{~m}^{3}$ in het gebied waar de suppletie is aangelegd. Ook in dit gebied zijn grote verschillen in totaal sedimentvolume gemeten, duidend op een grote meetonzekerheden. Sinds de aanleg is de suppletie sterk afgevlakt en verplaatst naar het oosten, waarbij erosie aan de westflank plaatsvond en sedimentatie over ongeveer 65 meter aan de oostflank van de suppletie. In het gebied met zandruggen aan de zuidrand van het meetgebied is veel dynamiek aanwezig, getuige de het chaotische patroon van sedimentatie en erosie dat hier zichtbaar is. Dit toont aan dat de zandruggen dynamisch zijn. 


\section{Conclusie en aanbevelingen}

De huidige monitoringopzet, met halfjaarlijkse bathymetrische opnamen met behulp van een Single Beam Echolood en een drijfconstructie met DGPS, volgt de ontwikkeling van de suppletie goed. Hiermee wordt veel nieuwe kennis over het systeem opgedaan.

De verwachting voor beide gebieden was dat het sediment zich kustwaarts zou verplaatsen. In het geval van Workum is er slechts een geringe hoeveelheid kustwaarts sedimenttransport. Het grootste deel van het sediment wordt getransporteerd in de dynamische zone met zandruggen, voornamelijk in noordelijke richting. Zandruggen vertonen seizonale dynamiek en verplaatsen zich lateraal zowel meerwaarts als kustwaarts, en veranderen in hoogte. Bij Oudemirdum vindt sedimentatie hoofdzakelijk aan de oostzijde van de aangebrachte suppletie plaats. Dit wil zeggen dat het gesuppleerde sediment kustwaarts wordt afgezet. Op langere termijn zou dit mogelijk kunnen leiden tot kustaanwas.

Deze pilot-experimenten geven belangrijke informatie over de werking van zandmotoren langs de Friese IJsselmeerkust. Op basis hiervan kunnen nieuwe ontwerpen worden gemaakt van strategisch geplaatste suppleties. Bovendien is de dataset zeer waardevol om morfologische modellen mee te kalibreren. Immers, als morfologische modellen de waargenomen veranderingen van de suppletie niet kunnen voorspellen (in snelheid, volumes etc.), is de voorspellende waarde voor de gevolgen van andere ingrepen ook beperkt.

Het idee van de zandmotoren is dat door golfwerking delen van de suppletie richting de kust gebracht worden en dat daarmee de kust wordt gevoed. Dit leidt tot dissipatie van golfenergie en daarmee tot een veiliger kust. Of dit effect behaald wordt kan op basis van de metingen bij Workum nog niet worden vastgesteld. Mogelijk leiden hogere zandruggen tot een toename van de golfdissipatie, waardoor de suppletie mogelijk nog steeds een versterkend effect op de oever heeft. Bij Oudemirdum wordt het sediment kustwaarts getransporteerd, en lijkt het erop dat het gewenste resultaat van het voeden van de kust wordt behaald. 


\section{Referenties}

Arcadis, 2013. Ecologische monitoring Building with Nature Friese Kust. Datarapport 2013. Rap.nr. C03041.003022.0100.

Wiersma, A.P., W. Sommer, P. Doornenbal, 2013. Morphological effects of a sand nourishment on a shallow shoreface in the IJsselmeer, offshore Workum. Dordrecht. Building with Nature.

Shore 2014a: Veldrapportage T3 April 2014 Peilwerkzaamheden BWN Pilot Oudemirdum.

Shore 2014b. Veldrapportage T5 juli 2014 Peilwerkzaamheden BWN Pilot Workum. 


\section{A Bijlagen}

\section{A.1 Workum}

A.1.1 Tabel sedimentvolume ten opzichte van T0, van T1 en van de voorgaande tijdstap.

\begin{tabular}{|c|c|c|c|c|c|c|c|c|c|}
\hline & $\begin{array}{c}\text { CELLS } \\
\text { [n] }\end{array}$ & $\begin{array}{c}\text { AREA } \\
\text { [m2] }\end{array}$ & MIN & MAX & RANGE & MEAN & STD & SUM & $\begin{array}{c}\text { VOLUME } \\
\text { [m3] }\end{array}$ \\
\hline t1 - t0 & 17735 & 443375 & -0.3966 & 1.0659 & 4625 & & & & 17863.60 \\
\hline t2 - to & 739 & 5 & & & & & & & \\
\hline t3 - to & 739 & 3475 & & 0.7 & & & & & \\
\hline t4 - to & 739 & 13475 & & 0. & & & & & \\
\hline t5 - to & 17739 & 43475 & -0.5 & 0.76 & & & & & \\
\hline t6 - to & 739 & 443475 & -0.5745 & 0.80 & 803 & & 0.13 & & 8287.36 \\
\hline t2 - t1 & 36510 & 912750 & -0.5662 & 0.6587 & 1.2249 & 001 & 0.0909 & & 12767.13 \\
\hline t3 - t1 & 36391 & 909775 & -0.7755 & $0.6 \mathrm{~s}$ & & & & & \\
\hline t4 - t1 & 36448 & 911200 & -0.7270 & 0.82 & & & & & 4212.07 \\
\hline t5 - t1 & 36521 & 913025 & -0.8880 & 0.85 & & & 0.1 & 148 & 37095.50 \\
\hline$t 6-t 1$ & 36521 & 913025 & -0.9163 & 0.7869 & 1.7033 & 0.0338 & 0.1556 & 1233.5076 & 30837.69 \\
\hline t1 - to & 17735 & 443375 & & 1.0659 & 1.4625 & & & & 17863.60 \\
\hline t2 - t1 & 36510 & 912750 & -0.5662 & 0.6587 & 1.2249 & 0.0140 & & 510.6852 & 12767.13 \\
\hline t3 - t2 & 36509 & 912725 & -0.4289 & 0.4806 & 0.9096 & -0.0111 & 0.0647 & -406.45 & -10161.35 \\
\hline t4 - t3 & 36473 & & & & & & & & 160 \\
\hline t5 - t4 & 36577 & & & & & & & 1316.7613 & 32919.03 \\
\hline t6 - t5 & 36650 & 916250 & -0.4368 & 0.5273 & 0.9641 & -0.0070 & 0.0867 & -256.1308 & -6403.27 \\
\hline
\end{tabular}

A.1.2 Tabel sedimentvolume suppletie

\begin{tabular}{|c|c|c|c|c|c|c|c|c|c|}
\hline & $\begin{array}{c}\text { CELLS } \\
{[\mathrm{n}]}\end{array}$ & $\begin{array}{l}\text { AREA } \\
\text { [m2] }\end{array}$ & MIN & MAX & RANGE & MEAN & STD & SUM & $\begin{array}{c}\text { VOLUME } \\
\text { [m3] }\end{array}$ \\
\hline t1 - to & 17,735 & 443,375 & -0.3966 & 1.0659 & 1.4625 & 0.0403 & 0.1697 & 714.5439 & 17863.60 \\
\hline t2 - to & 1,987 & 49675 & -0.5206 & 0.7623 & 0780 & 3287 & 43 & 53.08 & 16326.94 \\
\hline t3 - to & 1,987 & 49675 & -0.4965 & 0.7793 & 0411 & 0.2743 & 0.180 & 544.98 & 13624.40 \\
\hline t4 - to & 1,987 & 49675 & -0.5105 & 0.6255 & 1.1063 & 0.2319 & 0.168 & 460.84 & 11521.12 \\
\hline t5 - to & 1,987 & 49675 & -0.5432 & 0.6041 & 1.0997 & 0.1870 & 0.180 & 371.58 & 9289.61 \\
\hline t6 - to & 1,987 & 49,675 & -0.5745 & 0.7507 & 1.2309 & 0.1767 & 0.1830 & 351.14 & 8778.54 \\
\hline t2 - t1 & 2,010 & 50,250 & -0.5662 & 0.5350 & 1.1012 & -0.0730 & 0.1776 & -146.82 & -3670.46 \\
\hline t3 - t1 & 2,010 & 50,250 & -0.7755 & 0.5471 & 1.3226 & -0.1273 & 0.2040 & -255.86 & -6396.54 \\
\hline t4 - t1 & 2,010 & 50,250 & -0.7270 & 0.5455 & 1.2724 & -0.1705 & 0.2269 & -342.75 & -8568.79 \\
\hline t5 - t1 & 2,010 & 50,250 & -0.8880 & 0.4973 & 1.3854 & -0.2164 & 0.2658 & -434.94 & -10873.44 \\
\hline$t 6-t 1$ & 2,010 & 50,250 & -0.9163 & 0.5071 & 1.4235 & -0.2261 & 0.2609 & -454.43 & -11360.67 \\
\hline t1 - to & 1,987 & 49,675 & -0.5662 & 1.0659 & 1.1789 & 0.4013 & 0.2189 & 797.43 & 19935.73 \\
\hline t2 - t1 & 2,010 & 50,250 & -0.4339 & 0.5350 & 1.1012 & -0.0730 & 0.1776 & -146.82 & -3670.46 \\
\hline t3 - t2 & 2,010 & 50,250 & -0.5583 & 0.3109 & 0.6721 & -0.0543 & 0.1121 & -109.04 & -2726.08 \\
\hline t4 - t3 & 2,010 & 50,250 & -0.6250 & 0.5334 & 1.0664 & -0.04 & 0.1549 & -86.89 & -2172.25 \\
\hline t5 - t4 & 2,010 & 50,250 & -0.4368 & 0.3372 & 0.8796 & -0.0 & 0.1485 & -92.19 & -2304.65 \\
\hline t6 - t5 & 2,010 & 50,250 & -0.3966 & 0.4653 & 0.9021 & -0.0097 & 0.1770 & -19.49 & -487.23 \\
\hline
\end{tabular}


A.1.3 Tabel sedimentvolume diep

\begin{tabular}{|c|c|c|c|c|c|c|c|c|c|}
\hline & $\begin{array}{c}\text { CELLS } \\
{[\mathrm{n}]}\end{array}$ & $\begin{array}{c}\text { AREA } \\
\text { [m2] }\end{array}$ & MIN & MAX & RANGE & MEAN & STD & SUM & $\begin{array}{c}\text { VOLUME } \\
{[\mathrm{m} 3]}\end{array}$ \\
\hline t1 - to & 3,775 & 94,375 & -0.2377 & 0.3120 & 0.5497 & -0.0006 & 0.0536 & -2.2871 & -57.18 \\
\hline t2 - to & 3,779 & 94,475 & -0.2225 & 0.5126 & 0.7351 & 0.0224 & 0.0633 & 84.4723 & 2111.81 \\
\hline t3 - to & 3,779 & 94,475 & -0.3332 & 0.5315 & 0.8648 & -0.0022 & 0.0776 & -8.4805 & -212.01 \\
\hline t4 - to & 3,779 & 94,475 & -0.1816 & 0.3363 & 0.5179 & 0.0323 & 0.0542 & 121.9070 & 3047.68 \\
\hline t5 - to & 3,779 & 94,475 & -0.1798 & 0.4560 & 0.6358 & 0.1301 & 0.0575 & 491.5380 & 12288.45 \\
\hline t6 - to & 3,779 & 94,475 & -0.2211 & 0.6758 & 0.8968 & 0.0846 & 0.0795 & 319.5535 & 7988.84 \\
\hline $\mathrm{t} 2-\mathrm{t} 1$ & 8,907 & 222,675 & -0.2438 & 0.4005 & 0.6442 & 0.0073 & 0.0595 & 65.3221 & 1633.05 \\
\hline$t 3-t 1$ & 8,788 & 219,700 & -0.3496 & 0.3268 & 0.6764 & -0.0120 & 0.0698 & -105.5151 & -2637.88 \\
\hline t4-t1 & 8,845 & 221,125 & -0.3169 & 0.4211 & 0.7380 & 0.0226 & 0.0663 & 199.6941 & 4992.35 \\
\hline t5 - t1 & 8,918 & 222,950 & -0.2667 & 0.4798 & 0.7465 & 0.1260 & 0.0573 & 1123.3040 & 28082.60 \\
\hline$t 6-t 1$ & 8,918 & 222,950 & -0.2413 & 0.6331 & 0.8744 & 0.0827 & 0.0906 & 737.5428 & 18438.57 \\
\hline $\mathrm{t} 2-\mathrm{t} 1$ & 8,907 & 222,675 & -0.2438 & 0.4005 & 0.6442 & 0.0073 & 0.0595 & 65.3221 & 1633.05 \\
\hline t3 - t2 & 8,896 & 222,400 & -0.2729 & 0.1852 & 0.4582 & -0.0194 & 0.0533 & -172.7706 & -4319.26 \\
\hline$t 4-t 3$ & 8,860 & 221,500 & -0.2048 & 0.3387 & 0.5435 & 0.0345 & 0.0600 & 306.0515 & 7651.29 \\
\hline$t 5-t 4$ & 8,964 & 224,100 & -0.1214 & 0.2436 & 0.3650 & 0.1036 & 0.0412 & 929.0641 & 23226.60 \\
\hline t6 - t5 & 9,037 & 225,925 & -0.1981 & 0.2879 & 0.4860 & -0.0434 & 0.0543 & -392.6258 & -9815.64 \\
\hline
\end{tabular}

A.1.4 Tabel sedimentvolume ondiep

\begin{tabular}{|c|c|c|c|c|c|c|c|c|c|}
\hline & $\begin{array}{c}\text { CELLS } \\
{[\mathrm{n}]}\end{array}$ & $\begin{array}{c}\text { AREA } \\
\text { [m2] }\end{array}$ & MIN & MAX & RANGE & MEAN & STD & SUM & $\begin{array}{l}\text { VOLUME } \\
\text { [m3] }\end{array}$ \\
\hline t1 - to & 13,960 & 349,000 & -0.3966 & 1.0659 & & 0513 & & 716.8310 & 17920.78 \\
\hline - to & 13,960 & 3 & 6 & 0 & & & & & \\
\hline - to & 13,960 & 49,0 & -0.4 & 0 & & & & & \\
\hline t4 - to & 13,960 & 349,000 & -0.51 & 0.74 & & & & & \\
\hline t5 - to & 13,960 & 349,000 & -0.54 & 0.76 & 082 & & & & 3.90 \\
\hline t6 - to & 13,960 & 349,000 & -0.5 & 0.8059 & 3803 & & 44 & & 2029 \\
\hline $\mathrm{t} 2-\mathrm{t} 1$ & 27,603 & 690,075 & -0.5662 & 0.6587 & 1.2249 & 0.0161 & 0.0989 & 445.3631 & 11134.08 \\
\hline$t 3-t 1$ & 27,603 & 690,075 & -0.7755 & 0.6952 & 1.4707 & 0.00 & 1167 & 9762 & 5274.41 \\
\hline$t 4-t 1$ & 27,603 & 690,075 & -0.7270 & 0.8283 & 1.5553 & -0.0011 & 0.1422 & -31.2115 & -780.29 \\
\hline t5 - t1 & 27,603 & 690,075 & -0.8880 & 0.8503 & 1.7383 & 0.0131 & 0.1727 & 360.5161 & 9012.90 \\
\hline$t 6-t 1$ & 27,603 & 690,075 & -0.9163 & 0.7869 & 1.7033 & 0.0180 & 0.1684 & 495.9648 & 12399.12 \\
\hline $\mathrm{t} 2-\mathrm{t} 1$ & 27,603 & 690,075 & -0.5662 & 0.6587 & 1.2249 & 0.0161 & 0.0989 & 445.3631 & 11134.08 \\
\hline t3 - & 27,613 & 690,325 & -0.4289 & 0.4806 & 0.9096 & -0.0085 & 0.0678 & -233.6835 & -5842.09 \\
\hline t4 - & 27,613 & 690,325 & -0.5583 & 0.5625 & 1.1208 & -0.0088 & 0.0926 & -241.7901 & -6044.75 \\
\hline & 7,613 & 690,325 & -0.6250 & 0.6153 & 403 & 0.0140 & 0.1005 & 387.6972 & 9692.43 \\
\hline & & & & & & & & 130. & \\
\hline
\end{tabular}




\section{A.1.5 Profielen}
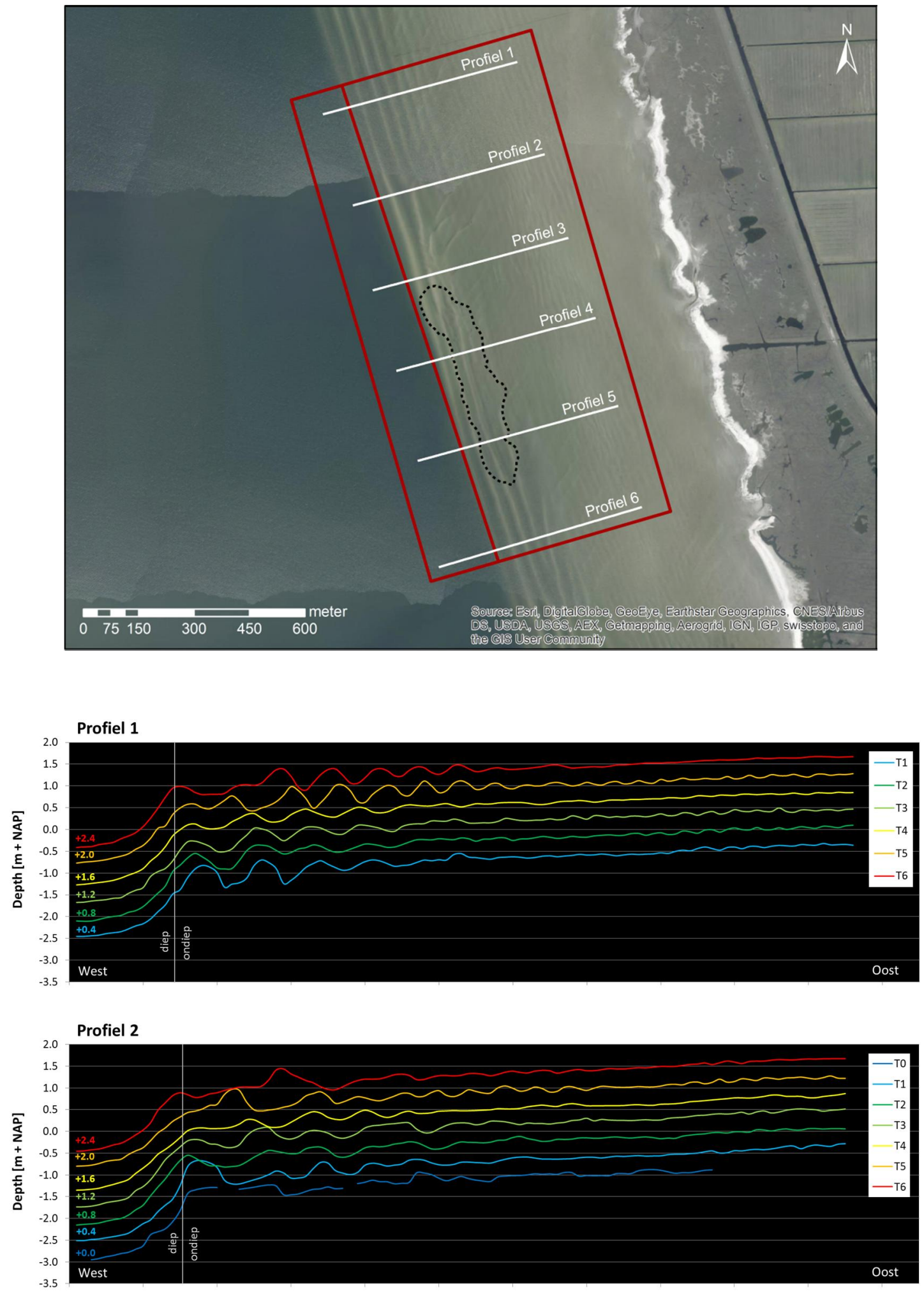


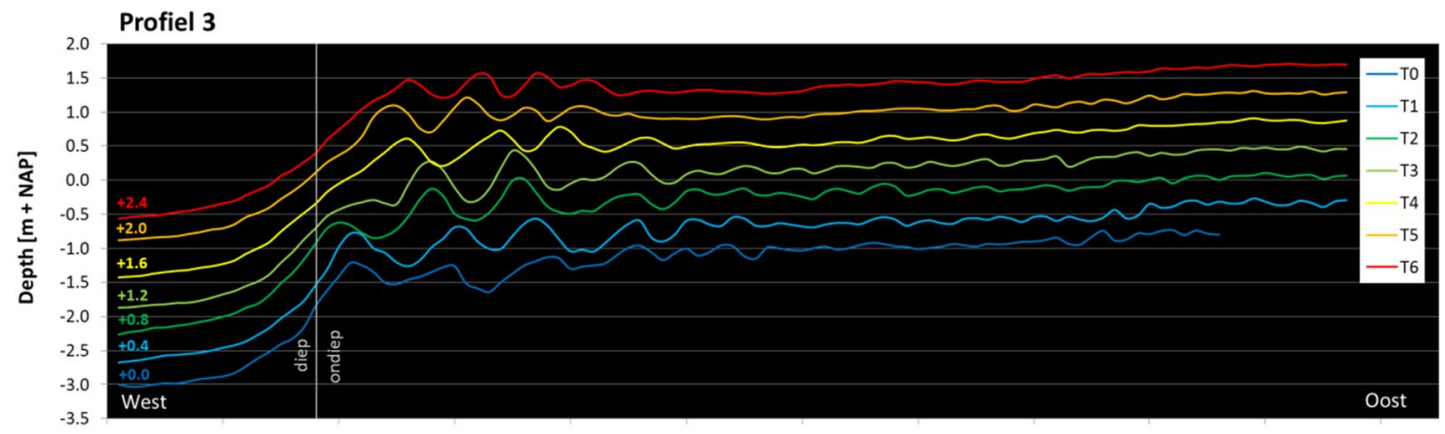

Profiel 4

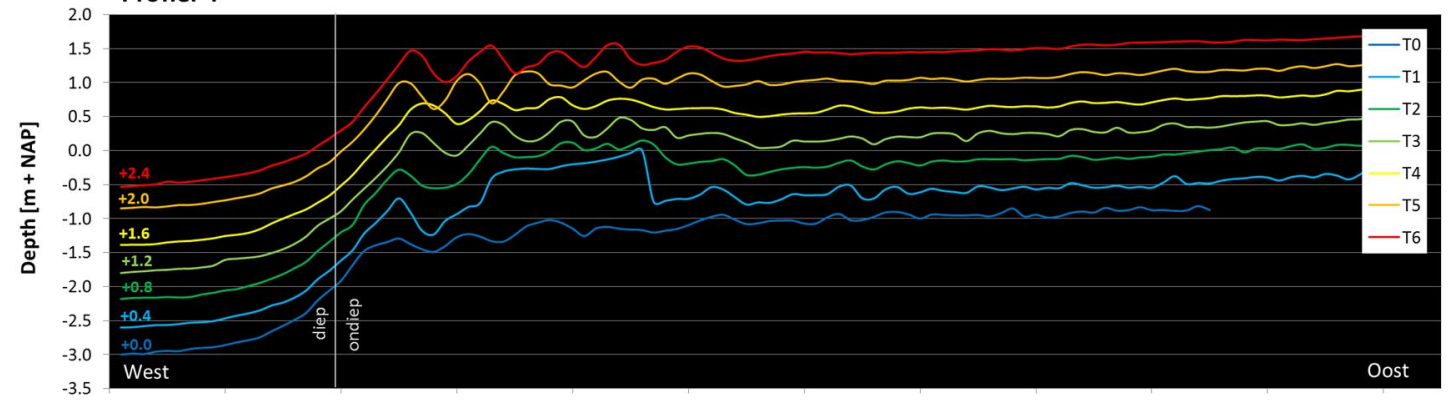

Profiel 5
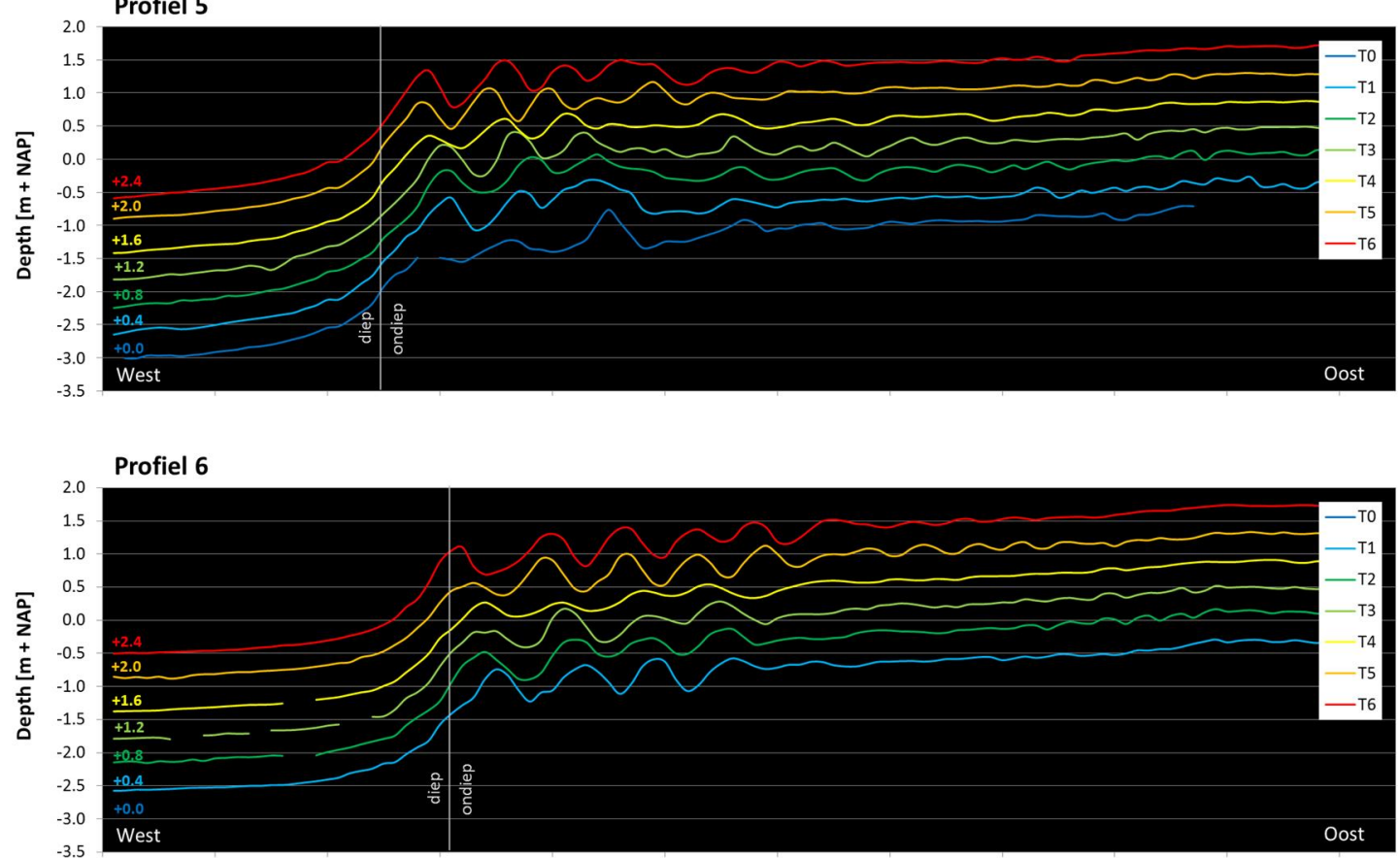


\section{A.2 Oudemirdum}

A.2.1 Tabel sedimentvolume ten opzichte van T0, van T1 en van de voorgaande tijdstap.

\begin{tabular}{|c|c|c|c|c|c|c|c|c|c|}
\hline & $\begin{array}{c}\text { CELLS } \\
\text { [n] }\end{array}$ & $\begin{array}{l}\text { AREA } \\
\text { [m2] }\end{array}$ & MIN & MAX & RANGE & MEAN & STD & SUM & $\begin{array}{l}\text { VOLUME } \\
\text { [m3] }\end{array}$ \\
\hline t1 - to & 13,225 & 330,625 & -0.4717 & 0.8577 & 1.3294 & 0,0511 & 0.13 & 675.6258 & 16890.64 \\
\hline t2 - to & 13,225 & 330,625 & -0.6128 & 0.5526 & 1.1654 & .0369 & 0.1330 & 87.8588 & 12196.47 \\
\hline t3 - to & 13,224 & 330,600 & -0.5063 & 0.6484 & 1.1547 & 0.0536 & 0.1280 & 708.6195 & 17715.49 \\
\hline t4 - to & 13,225 & 330625 & -0.5332 & 0.5653 & 1.0985 & 0.0147 & 0.1273 & 194.0817 & 4852.04 \\
\hline t2 - t1 & 13,226 & 330650 & -0.5039 & 0.4160 & 0.9198 & -0.0142 & 0.0819 & -187.7751 & -4694.38 \\
\hline t3 - t1 & 13,224 & 330600 & -0.5059 & 0.4717 & 0.9776 & 0.0025 & 0.0959 & 32.7817 & 819.54 \\
\hline$t 4-t 1$ & 13,226 & 330650 & -0.6392 & 0.4241 & 1.0633 & -0.0364 & 0.1304 & -481.3731 & -12034.33 \\
\hline t2 - t1 & 13,226 & 330650 & -0.5039 & 0.4160 & 0.9198 & -0.0142 & 0.0819 & -187.7751 & -4694.38 \\
\hline t3 - t2 & 13,224 & 330600 & -0.3452 & 0.4398 & 0.7850 & 0.0167 & 0.0632 & 220.5329 & 5513.32 \\
\hline$t 4-t 3$ & 13,224 & 330600 & -0.5165 & 0.4504 & 0.9669 & -0.0389 & 0.0910 & -514.5379 & -12863.45 \\
\hline
\end{tabular}

A.2.2 Tabel sedimenvolume suppletie

\begin{tabular}{|c|c|c|c|c|c|c|c|c|c|}
\hline & $\begin{array}{c}\text { CELLS } \\
{[\mathrm{n}]}\end{array}$ & $\begin{array}{l}\text { AREA } \\
\text { [m2] }\end{array}$ & MIN & MAX & RANGE & MEAN & STD & SUM & $\begin{array}{c}\text { VOLUME } \\
\text { [m3] }\end{array}$ \\
\hline- to & & 39275 & & & & & & & 12669.09 \\
\hline 2 - t0 & & 3927 & & & & & & & \\
\hline t3 - t0 & & 3927 & & & & & & & \\
\hline t4 - to & & 3927 & & & & & & & \\
\hline t2 - t1 & & & & & & & & & \\
\hline t3 - t1 & & & & & & & & & \\
\hline $\mathrm{t} 4-\mathrm{t} 1$ & 1,571 & 39275 & -0.5560 & 0.3630 & & -0.1672 & 0.1898 & -262.6924 & -6567.31 \\
\hline$t 2-t$ & & & & & & & & & \\
\hline & & & & & & & & & \\
\hline$t 4-t 3$ & 1,571 & 39275 & -0.3460 & 0.2795 & 0.6255 & -0.1231 & 0.0950 & -193.3160 & -4832.90 \\
\hline
\end{tabular}




\section{A.2.3 Profielen}

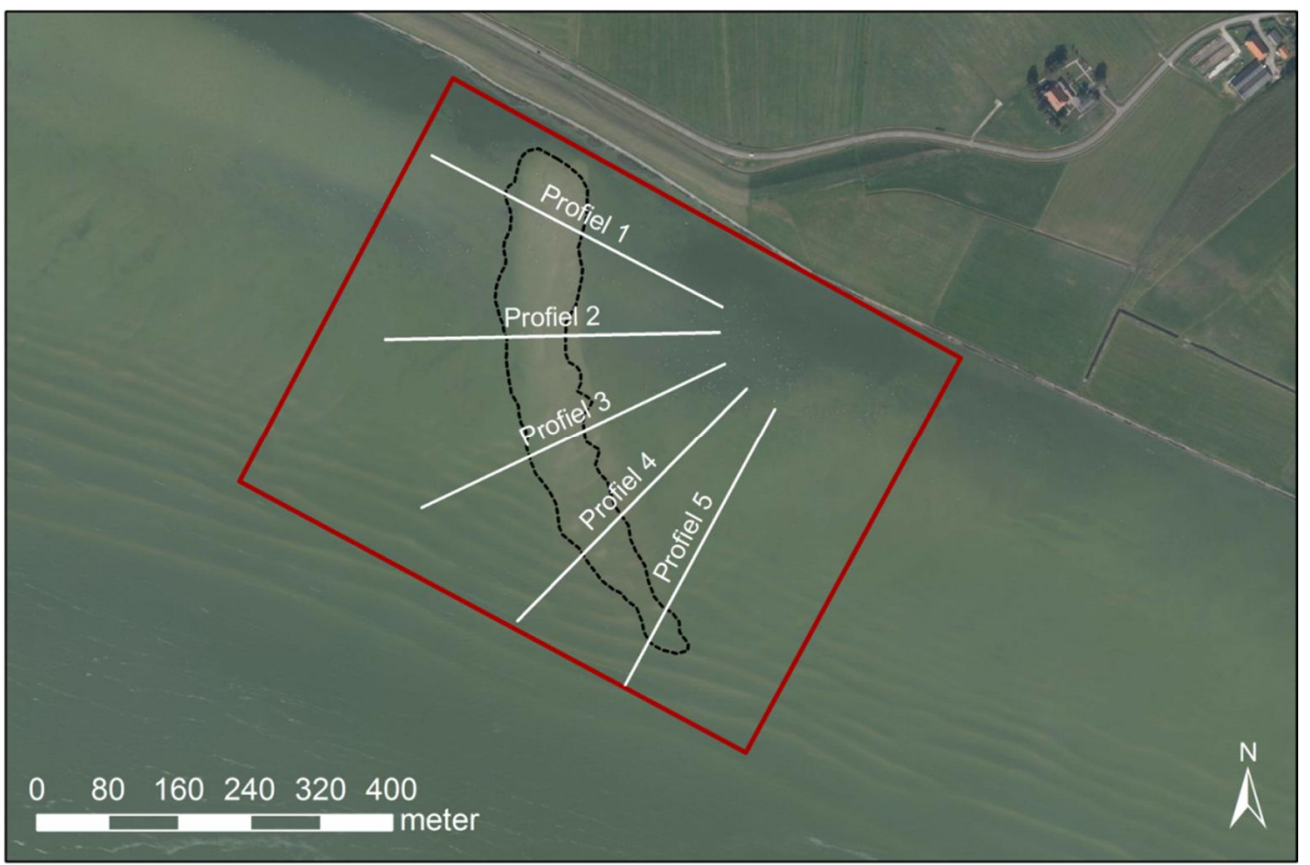

\section{Profiel 1}

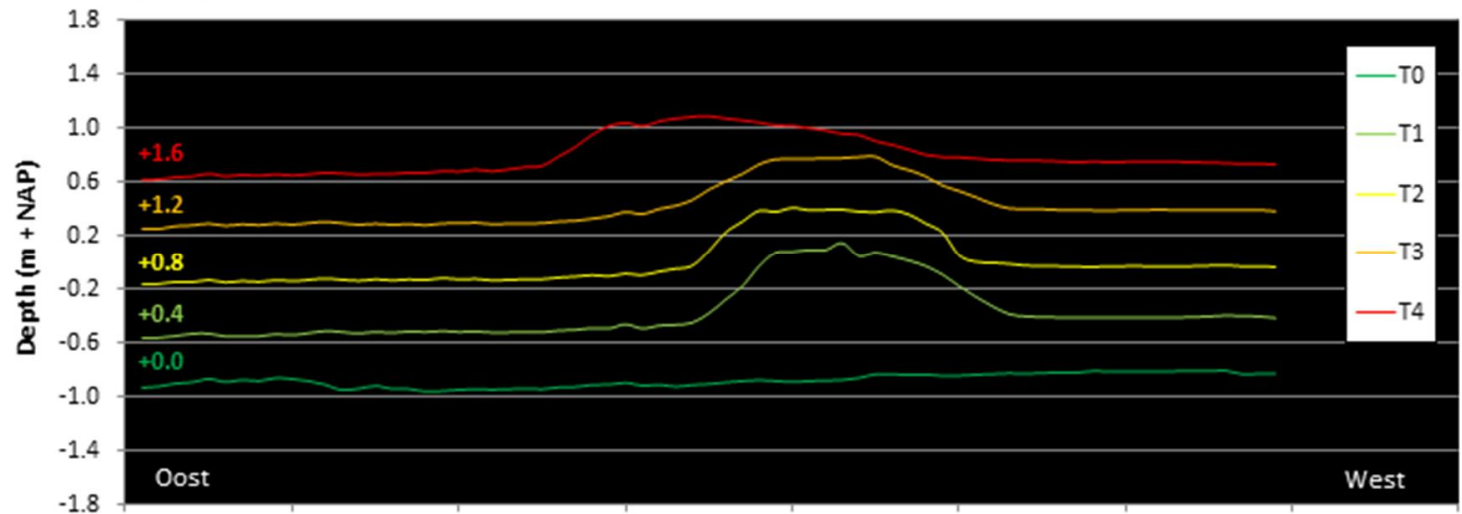

\section{Profiel 2}

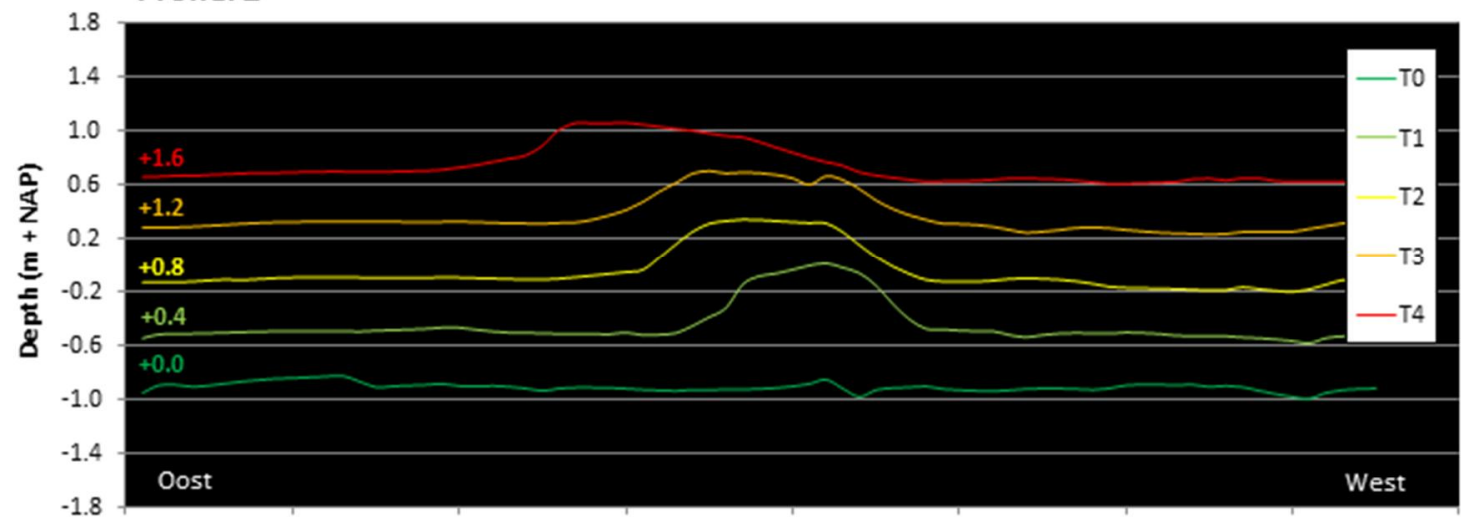



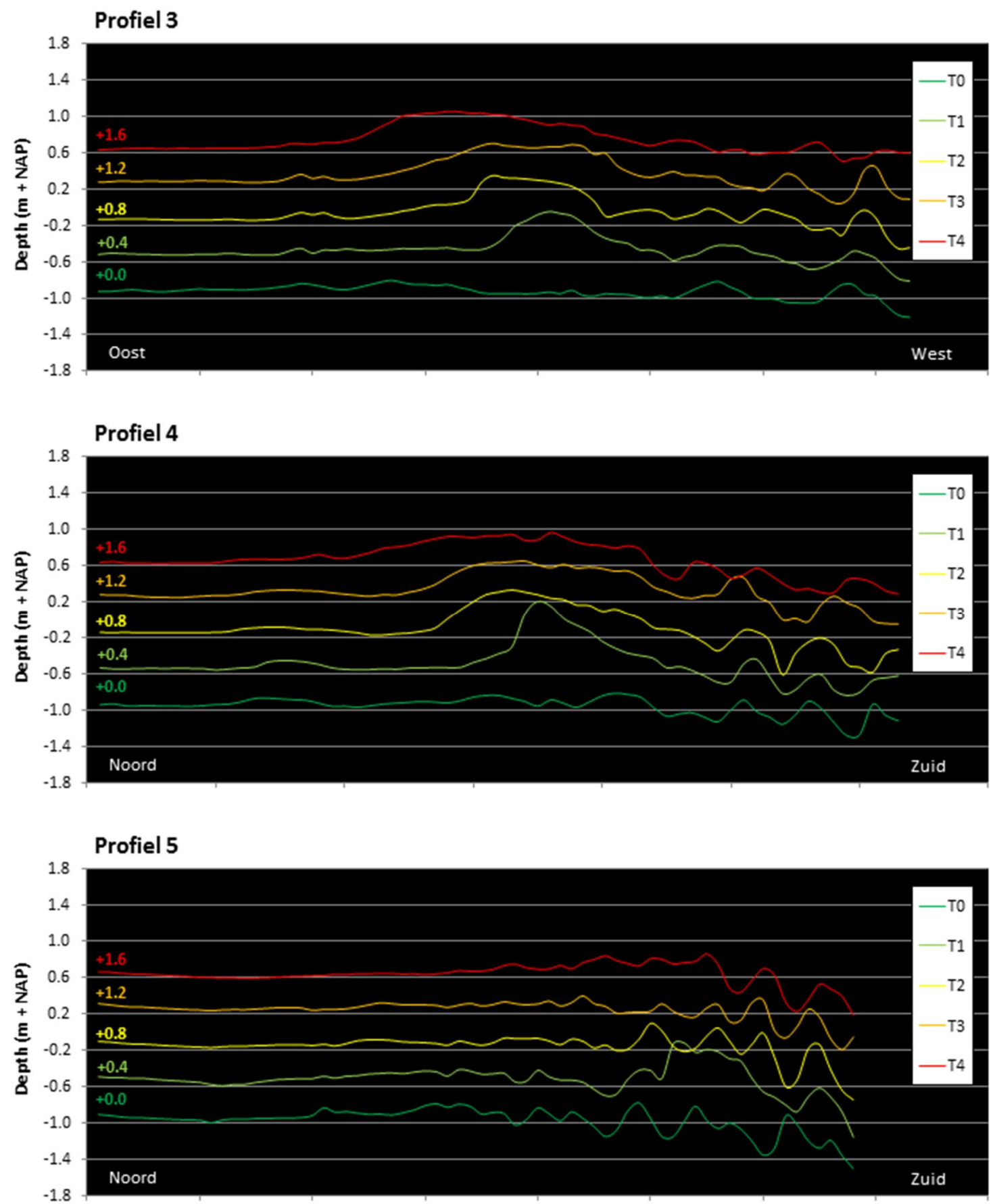


\section{B Bijlage B}

Monitoring of the vegetation development in the Workumer buitenwaarden for assessing the effects of sand nourishment 


\section{MONITORING OF THE VEGETATION \\ DEVELOPMENT IN THE WORKUMER}

BUITENWAARDEN FOR ASSESSING THE EFFECTS

OF SAND NOURISHMENT

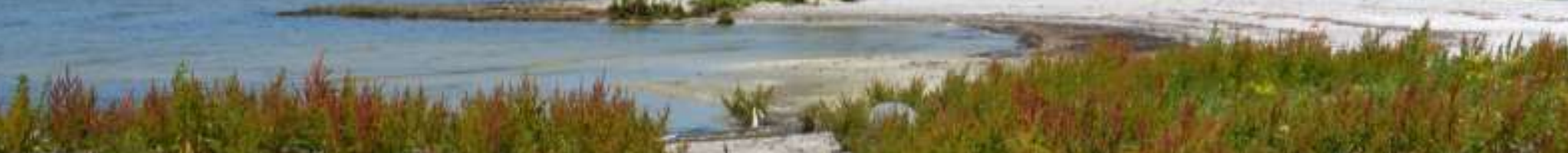

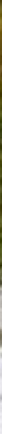

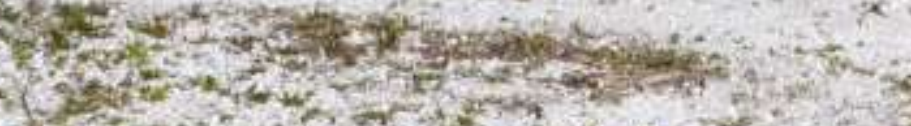

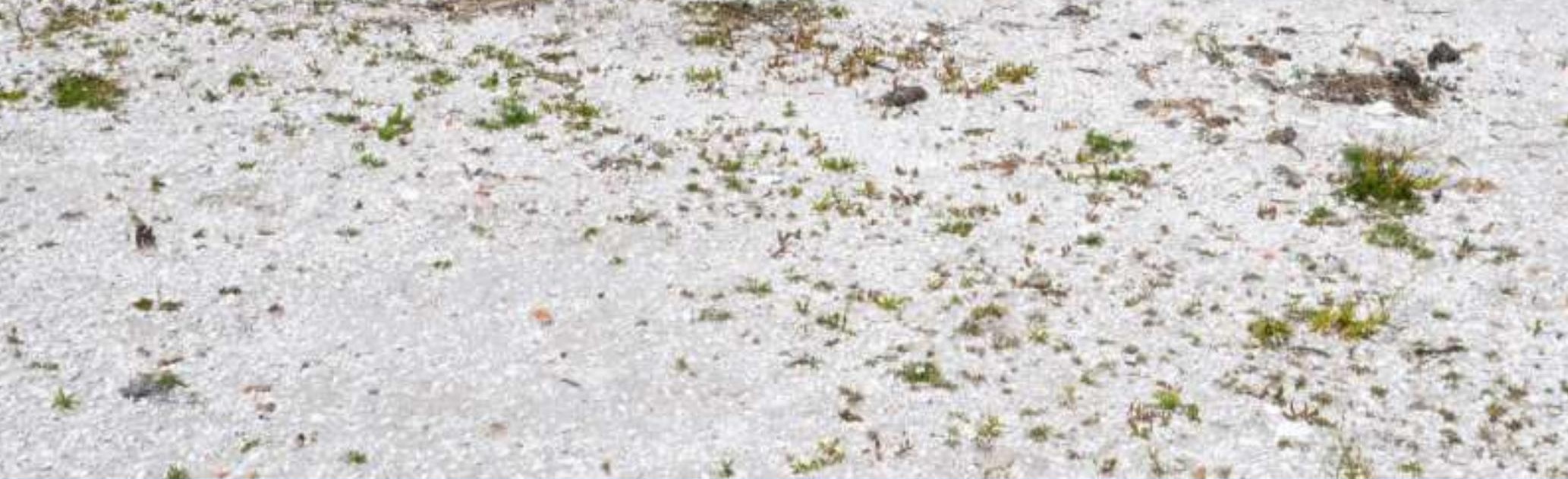

8 Econecover 


\section{MONITORING OF THE VEGETATION DEVELOPMENT IN THE WORKUMER BUITENWAARDEN FOR ASSESSING THE EFFECTS OF SAND NOURISHMENT}

Nederlandse Titel: MONITORING VAN VEGETATIEONTWIKKELING IN DE WORKUMER BUITENWAARDEN VOOR DE BEOORDELING VAN DE EFFECTEN VAN DE ZANDMOTOR

Agata Klimkowska

Commissioned by: Stichting DELTARES

Postbus 85467, 3508 AL Utrecht

Contact person: Dr. Ane Wiersma

Applied geology and geophysics

Tel: +31 (0) 883357176

E-mail: Ane.Wiersma@deltares.nl

Author: Dr. A. Klimkowska

Date: 11.08.2015

Colophon:

Eco-Recover, Ecosystem Restoration Advice Dr. Agata Klimkowska

Address: Labriehof 21, 6952 HW Dieren (NL)

Phone: (+31) 0629346019

Email: agataklimkowskajobse@gmail.com

www.agataklimkowska.eu

K.v.K. nummer 58052844 


\section{SAMENVATTING}

In dit project wordt de vegetatieontwikkeling van de Workumerwaard gemonitord om effecten van zandsuppletie op de vooroever vast te kunnen stellen. Het is een voortzetting van het project dat is begonnen in 2011 en is uitgevoerd in 2012, en nu ook in 2015. Er zijn 32 permanente plots (PQ's) van $4 m^{2}$ vastgelegd waarvan de soortensamenstelling en de structuur van de vegetatie is vastgesteld. Tevens is de hoogteligging bepaald.

De resultaten laten zien dat de vegetatie tussen 2011 en 2015 significant veranderd is, maar het is niet waarschijnlijk dat dit een gevolg is van zandsuppletie. De veranderingen in de vegetatie zelf (soortensamenstelling en abundantie) wijzen op een afname van de landhoogte en een toename van oppervlakte kale grond. Voor de vegetatie op de schelpenbanken is een afname van de oppervlakte kale grond geconstateerd. De veranderingen in hoogteligging zijn verwaarloosbaar of wijzen op een afname van de hoogte, vooral binnenlands. Het gebied wordt begraasd en dit heeft effecten op de vegetatie. Begrazing is wellicht gedeeltelijk verantwoordelijk voor de waargenomen veranderingen in de vegetatie, maar het is niet vast te stellen in welke mate.

In het algemeen is de interpretatie van de resultaten beperkt door de heterogeniteit van de vegetatie, discrepanties tussen verschillende vegetatie typen en door het ontbreken van kwantitatieve gegevens over hydrologie en begrazingsintensiteit.

Gezien de dynamiek van de veranderingen in het gebied en de aanhoudende omvorming van de vegetatie, met verzwakking van de wortelzone tot gevolg, wordt aanbevolen om de monitoring op dezelfde wijze voort te zetten, met een lage waarnemingsfrequentie (eenmaal per 3-5 jaar).

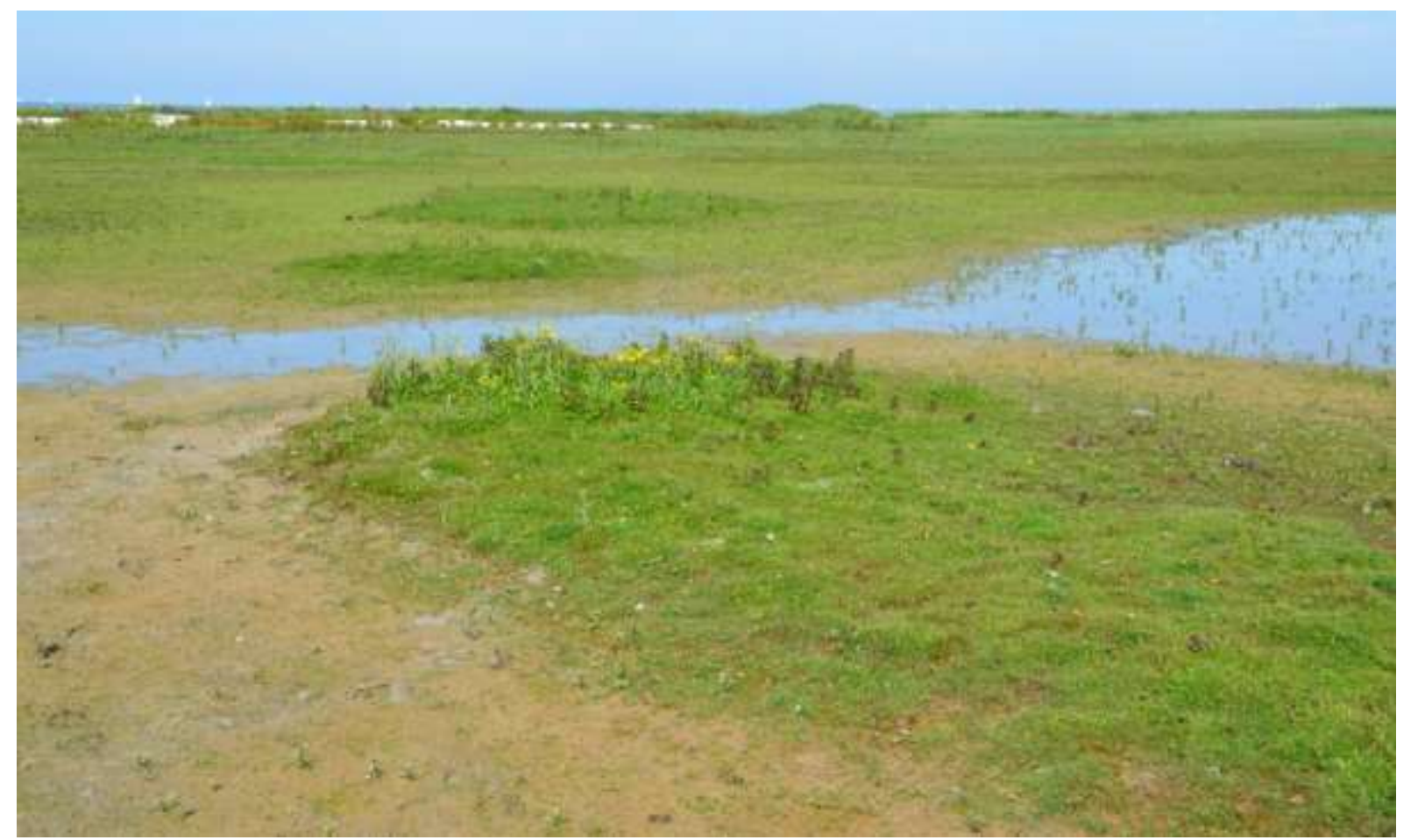

Vorming van plassen en zeer korte vegetatie op Workumerwaard. (C) A. Klimkowska 2015 


\section{Table of Contents}

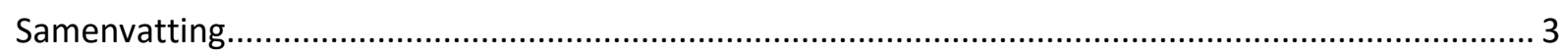

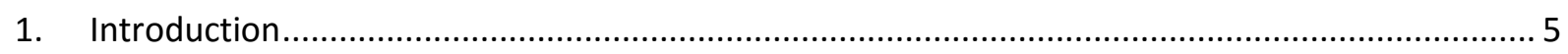

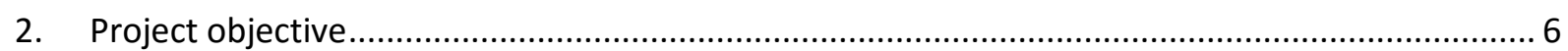

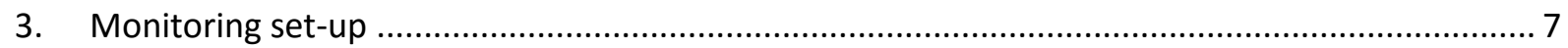

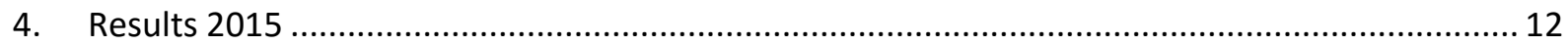

5. Vegetation development in a historical perspective ................................................................. 30

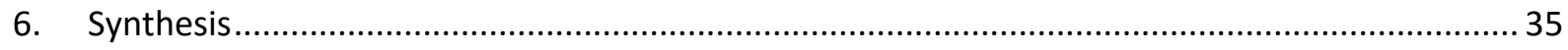

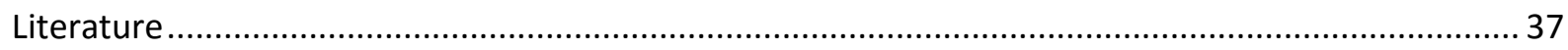

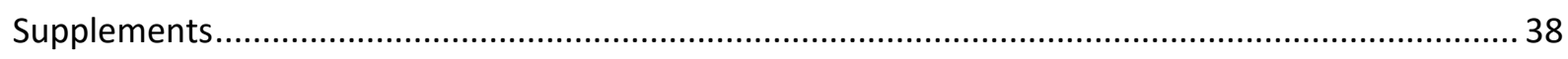

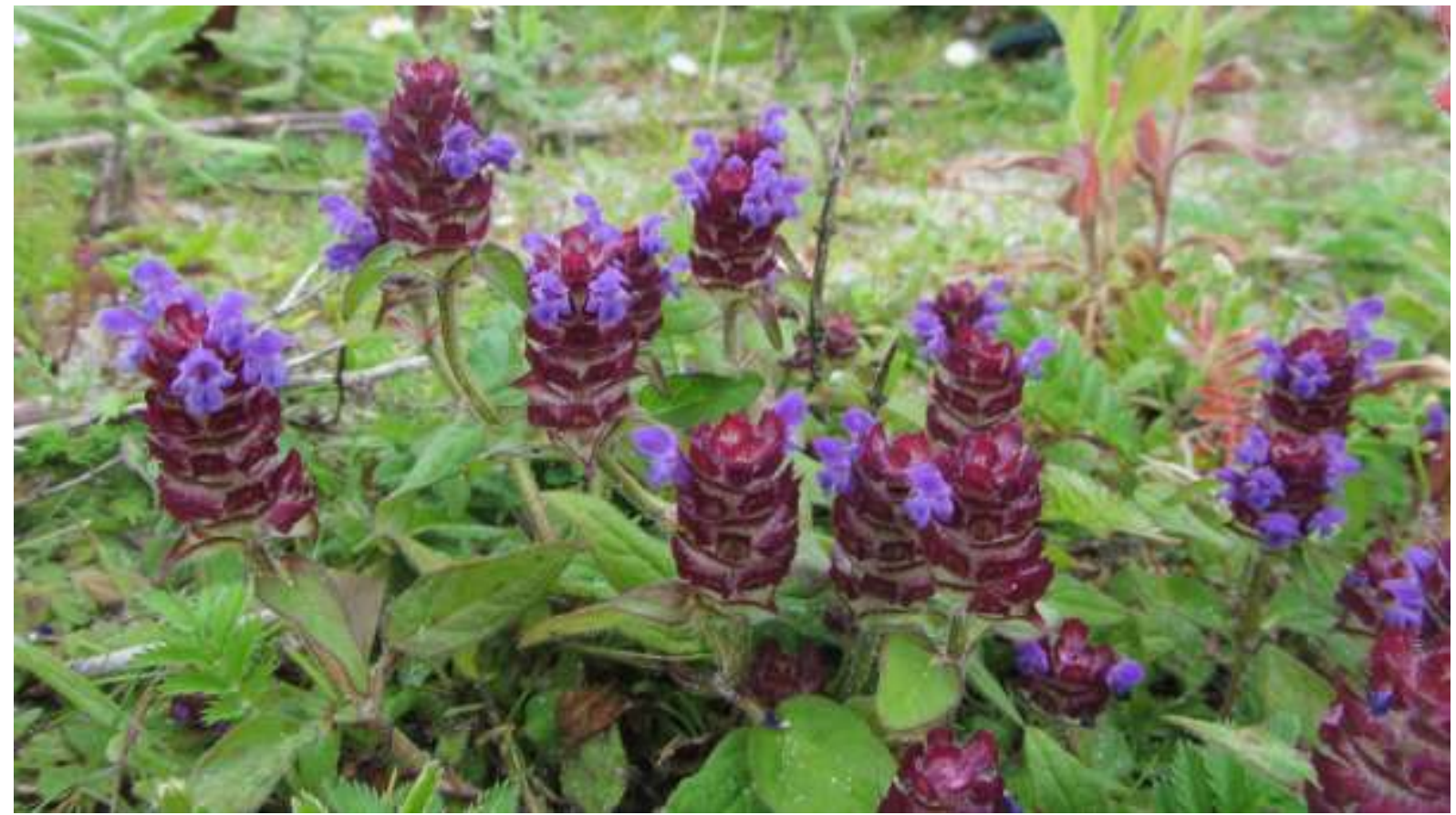

Prunella vulgaris on the sand banks of Workumerwaard. (C) A. Klimkowska 2015 


\section{INTRODUCTION}

The Workumer Buitenwaarden (or Workumerwaard) is a marshy foreland area outside the levees along the Frisian coast of Lake IJssel (IJsselmeer), nearby the town of Workum. The forelands improve inland safety by dissipating wave energy and acting as a buffer. Besides protecting the area from flooding, it is an important nature area of the organisation 'It Fryske Gea' and one of the crucial bird protection areas in the region. It belongs to a larger Natura 2000 site 'IJsselmeer'.

Workumerwaard hosts a large population of meadow birds, waders, geese, shore birds, gulls and sterns. Regionally it is also important for migratory birds (geese, swans, ruffs). Many locations along the coast are used for water recreation.

Due to the changes in water management imposed by climate adaptation (rise of the lake level to increase fresh water retention) and more frequent storms, it is expected that the forelands may be flooded and will be more often exposed to wave erosion and consequently can disappear completely. This will have large consequences for safety as well as for nature conservation on the Frisian coast. An innovative solution was proposed to sustain a safe situation along the levees while maintaining other functions of the area: 'soft sand engines Frisian IJsselmeer shore'. The sand engine ("zandmotor") approach makes use of sedimentary dynamics of a natural system to transport sediment from sand nourishment to the coast. However, this approach has not been proven in a low energy setting, such as the coast of the Lake IJssel. In the 'Building with Nature' program, a pilot design for Workumer Buitenwaarden was proposed as a measure to maintain the forelands of the Frisian coast, with the objective to explore the behaviour of the sedimentary and ecological systems.

The Workumer Buitenwaarden pilot has started in 2011 and consisted of sand nourishment in front of the nature reserve. A nourishment of $25.000 \mathrm{~m}^{3}$ sand has been added in autumn $2011, \mathrm{c} .500 \mathrm{~m}$ outside the shoreline. Additionally an 'eco-dynamic dam' (consisting of wooden poles to slow down the water movement northwards) has been built, to facilitate the deposition of sand.

For an evaluation of the effectiveness of such measures in a low wave-energy setting and for the up scaling of the pilot solutions, a clear understanding of the ecological responses of the system is crucial. Because nature conservation is an important function of the area, a detailed monitoring of the vegetation development was established.

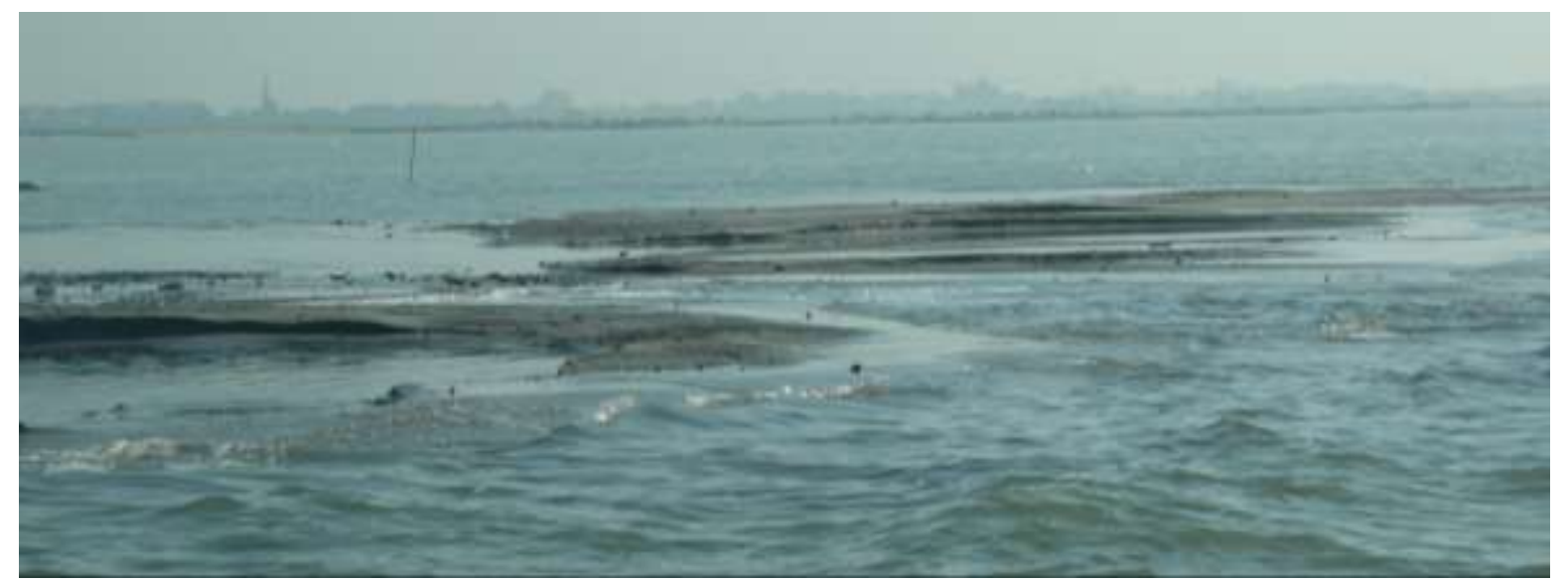

Sand nourishment of Workumer Buitenwaarden a pilot project just after construction in 2011 (source: https://publicwiki.deltares.nl/). 
The ecological processes and an enhancement of the quality of habitats (of Natura 2000) were evaluated on the bases of the vegetation development. An overall objective of the monitoring was to evaluate the effects of the pilot sand nourishment on the system development.

The aim of this project was to collect monitoring data on the vegetation development, perform a simple analysis and interpretation of the results, followed by an evaluation of the effects of the pilot sand nourishment and other observed developments. The reference situation (TO, before implementation of the pilot), and a situation in the first year after sand nourishment were recorded in 2011 and 2012, respectively. This report presents the results of the terrestrial vegetation monitoring in 2015.

For this purpose the monitoring of the following parameters was carried out: (1) vegetation composition and development; (2) vegetation structure; (3) elevation height measured within vegetation.

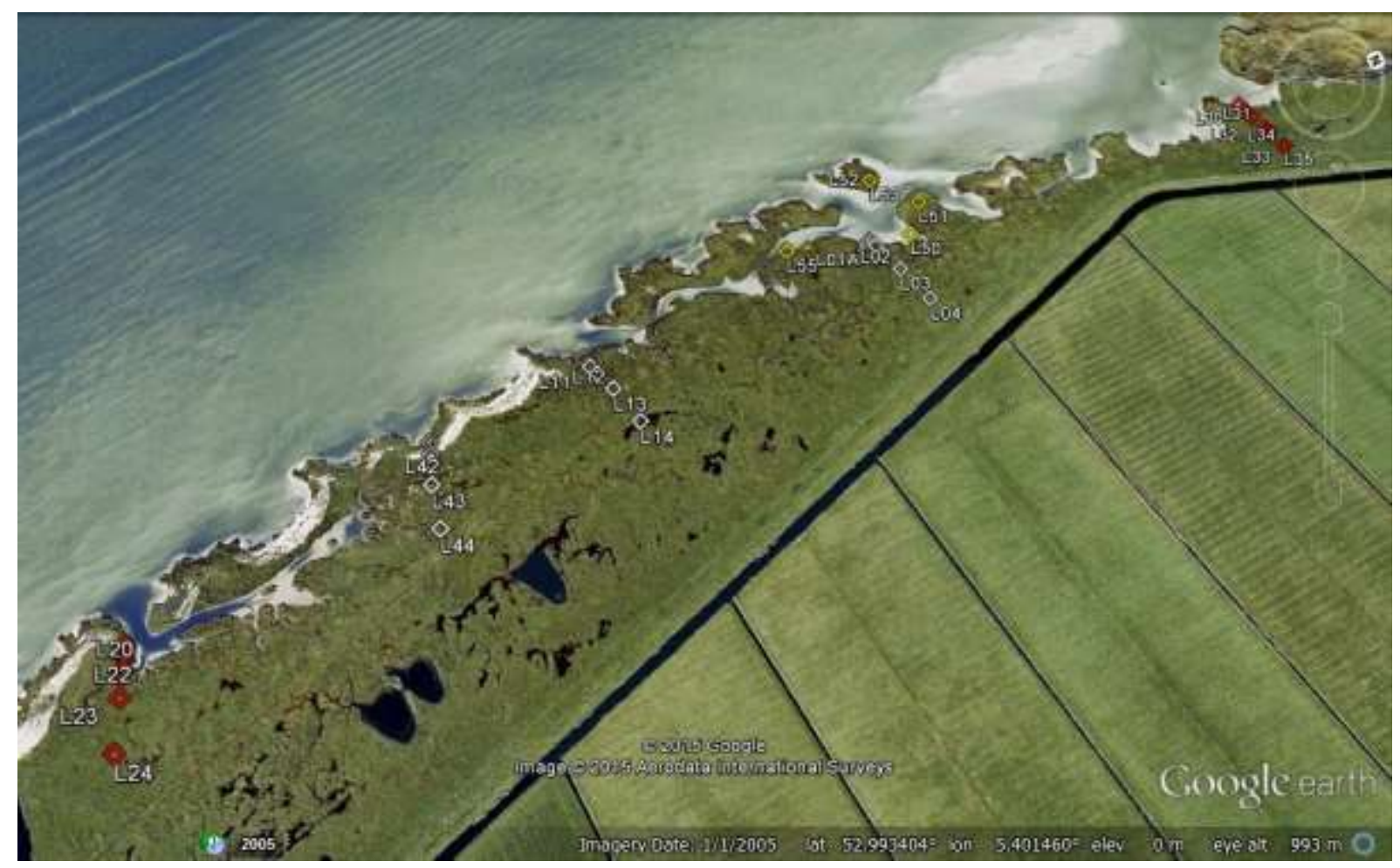

Figure 3.1: Location of the plots in the monitoring area. Symbols: white icons - effect plots; red icons - control plots; yellow icons - scattered plots near the dam. Google earth image was used as a background. 


\section{MONITORING SET-UP}

Monitoring took place in the northern part of the Workumerwaard area, on the permanent plots (Permanent Quadrants, called further PQs), that have been established in 2011, during the first monitoring round (Klimkowska et al. 2011). The same monitoring method was applied in this project. Some activities, namely evaluation of the root density, evaluation of standing crop biomass, evaluation of belowground (root) biomass, were not carried out in 2015, but only in 2011 and 2012 .

\subsection{MONITORING OF THE VEGETATION DEVELOPMENT}

In order to evaluate the effect of the sand nourishment, the vegetation composition and its development over time (before and after sand nourishment) were compared. The effects of sediment deposition on the vegetation is most likely spatially heterogeneous along the coast and decreases with the distance from the shoreline. Therefore, the PQs were located along the coast, in the zone where sediment deposition was expected, along transects perpendicular to the shoreline (Table 1, plots are also indicated on the aerial photograph in Supplement A). The monitoring was concentrated in the shore zone, where the largest changes were expected to take place. For gathering reliable data, a representative number of PQs was established. In order to account for the autonomous processes in the area, control transects were established. These transects were located where no effect of sand engine was predicted or would be negligible. In order to explore the effect of the 'eco-dynamic dam' several scattered plots were established in its vicinity. The changes in the vegetation on islands or sand banks were also monitored.

Description of the PQs:

- PQs were of a standard size of $4 \mathrm{~m}^{2}$ (a circle with $r=1.13 \mathrm{~m}$, diameter=2.26 m). A central point was precisely located with a high resolution DGPS to repeat observations in the same location as in the previous years (coordinated of the plots were provided in Supplement B);

- $\quad$ PQs were placed along 5 transects, approx. perpendicular to the shoreline (Fig. 3.1). Six PQs were located close to transect 1 , i.e. close to the biodynamic dam. In total $32 \mathrm{PQ}$ s were established;

- Transects were c. $100 \mathrm{~m}$ long and consisted of 5-6 PQs, starting from c. 1-2 m from the shoreline, and other plots at c. $12.5 \mathrm{~m}, 25 \mathrm{~m}, 50 \mathrm{~m}$ and $100 \mathrm{~m}$ from the first plot (Tab.1);

- $\quad$ PQs were recorded according to plant-sociological standards, using the (modified) BraunBlanquet scale of species abundance. All vascular plants species and dominant mosses were identified. Data were stored in format 'Turboveg for Windows' database;

- Besides plant species composition, also other characteristics of the vegetation / ground cover were recorded: vegetation height (average and maximum), cover of bare soil, cover of water, cover of litter;

- Monitoring was carried out in the beginning of July (2011 in the end of June and in 2012 in the beginning of July), which was optimal for species identification. The time and practical realisation of the monitoring was consulted with the terrain manger (It Fryske Gea); 
- $\quad$ Cattle, horses, geese, graze the Workumerwaard area. The grazing pressure varies in time and space. As grazing is considered part of the system, the PQs were not fenced.

Table 1: Short characteristic of the monitoring transects (from north to south).

\begin{tabular}{|c|c|c|c|c|}
\hline Transect & No. of PQs & PQs codes & Effects / control & Type of coast \\
\hline Transect 4 & 6 & L30 t/m L35 & Control & Marshy \\
\hline Transect 1 & 5 & L01 t/m L04 & $\begin{array}{l}\text { Effect, closest to dam, close to aquatic } \\
\text { transect }\end{array}$ & Marshy \\
\hline $\begin{array}{l}\text { Scatter } \\
\text { plots }\end{array}$ & 6 & L50 t/m L55 & Effect, vicinity of dam & Various \\
\hline Transect 2 & 5 & L10 t/m L14 & $\begin{array}{l}\text { Effect, closest to dam, close to aquatic } \\
\text { transect }\end{array}$ & Shall bank \\
\hline Transect 5 & 5 & L40 t/m L44 & Effect & Shall bank \\
\hline Transect 3 & 5 & $\mathrm{~L} 20 \mathrm{t} / \mathrm{m} \mathrm{L24}$ & Control, close to aquatic transect & Shall bank \\
\hline
\end{tabular}

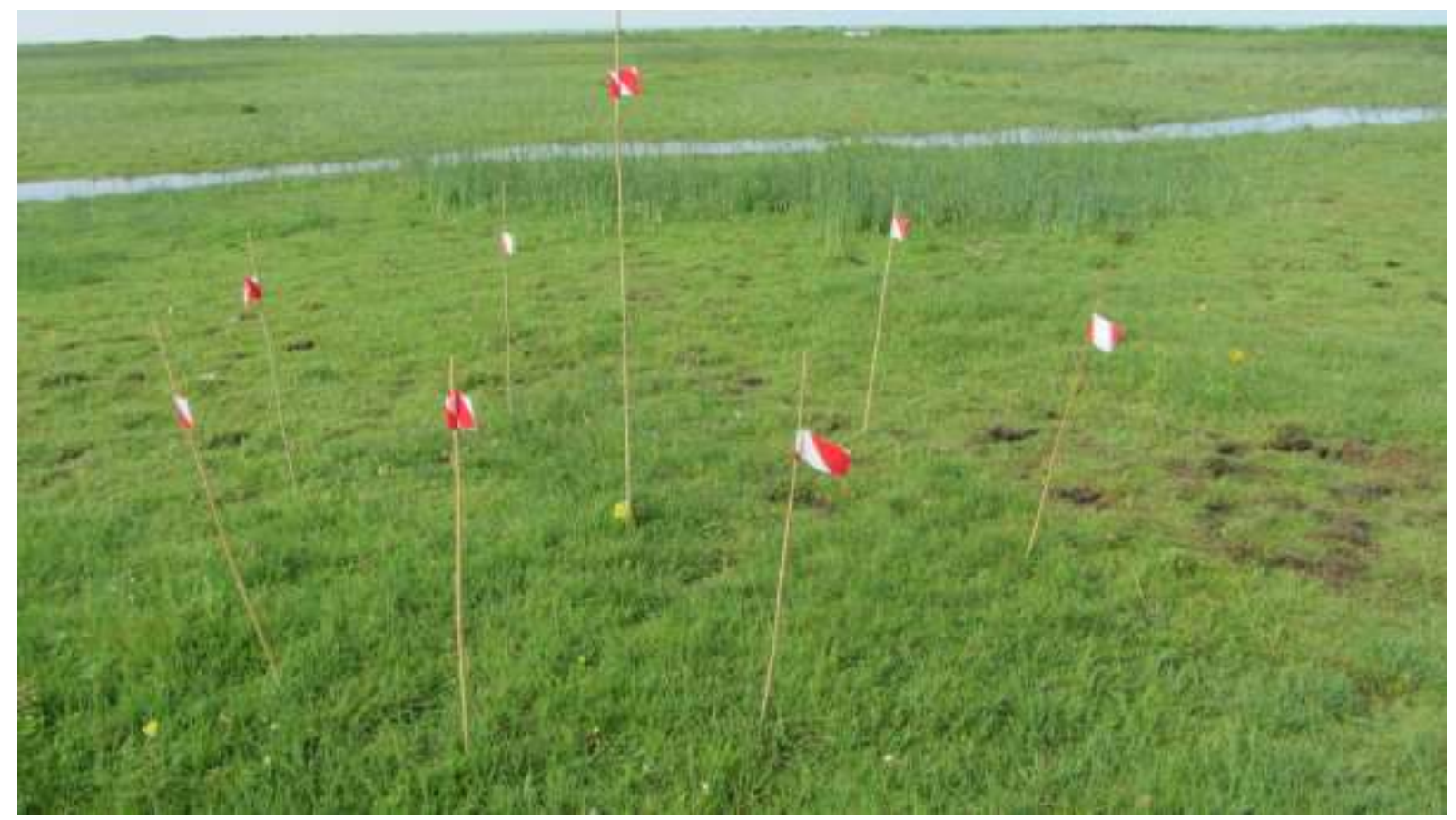

One of the monitoring PQs (C) A. Klimkowska 2015 


\subsection{LAND MORPHOLOGY WITHIN THE VEGETATION AND VEGETATION STRUCTURE}

For information on the land morphology within the vegetation or on the possible sediment deposition within the vegetation, the elevation of the permanent plots was measured using DGPS technology with a Hemisphere S320 RTK GPS receiver (with an automatic 06-GPS correction). The 06GPS RTK network provides an accuracy of $1-2 \mathrm{~cm}$ for XY coordinates, and of 2-3 cm for elevation (Zdimension). In each plot, besides measurement of the centre, 5 additional measurements were taken, within 1-meter radius, to account for micro-relief.

The formation of a zonation in the vegetation, as well as the extent to which the vegetation captures sediment or slows down wave action, depends on vegetation structure: its height, cover and roughness. Some of these characteristics were evaluated parallel to the species composition. The vegetation structure was evaluated with following parameters:

- average height of tall herb layer (and when relevant average height of low herb layer)

- maximum height (height of the tallest herbs)

- percentage cover of herbs

- percentage cover of bare soil (or water)

Although grazing is considered part of the system, it strongly influences vegetation structure and vegetation composition. The grazing pressure is locally high (cows, horses, geese). Cattle grazing intensity is relatively stable over the years, but it varies within the year: less intensive or none in spring, more intensive in summer, usually from late May / June, until late autumn. Horses are allowed to graze in the area incidentally. Geese contribute to the grazing pressure, mainly in the winter and early spring.
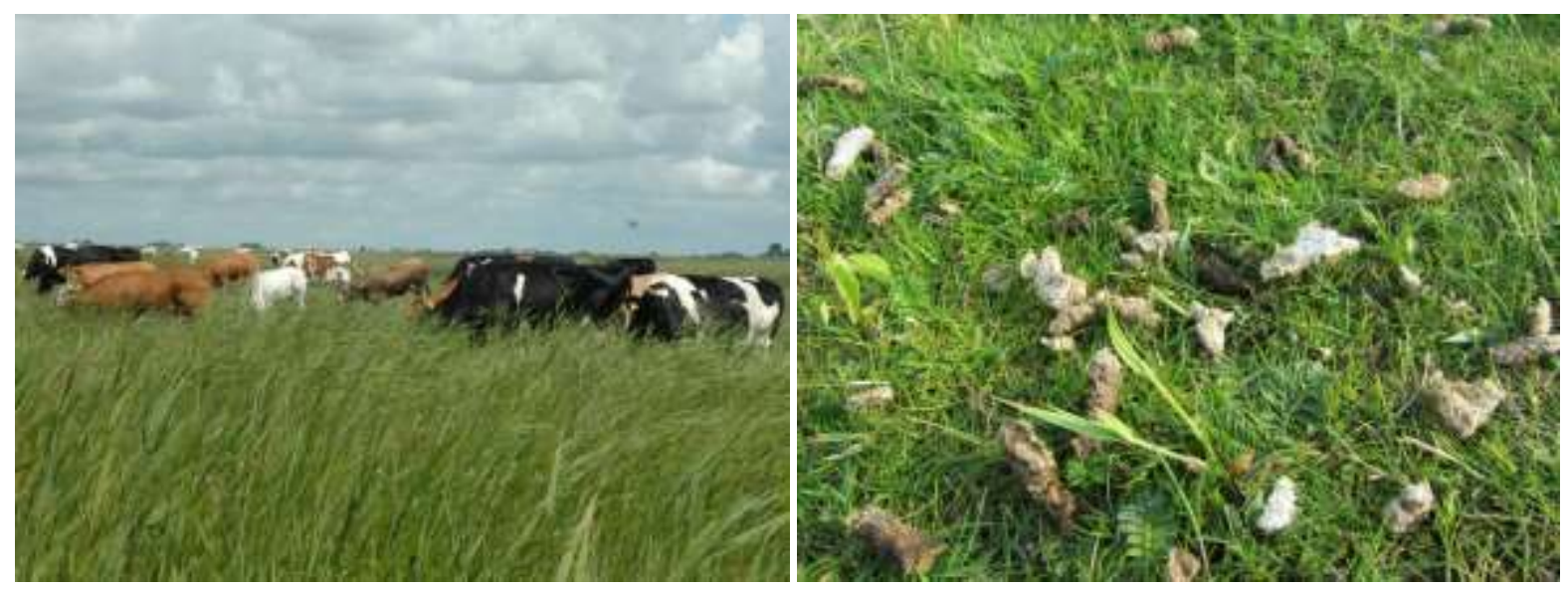

Cattle grazing in the reed vegetation and a high density of geese droppings in the short vegetation evidence of grazing pressure (c) A. Klimkowska 2011 


\subsection{METHODS OF DATA ANALYSIS}

First, the results of the monitoring in 2015 are described, followed by a short description of the analysis of the changes in parameters from 2011 to 2015.

Data on the elevation and vegetation structure was described for vegetation types and tested for differences over time. The differences in elevation between 2011 and 2015 were calculated for each plot (from DGPS data, reflecting the elevation within the vegetation). For the analysis, simple statistical methods were used (ANOVA).

The vegetation on the transects is separated into 6 classes. The species composition and contribution of each species can vary naturally within each vegetation type. Due to the large variability within each transect, the differences between control and effect transects are probably undetectable. These differences can be best analysed on the level of vegetation types and these changes are also ecologically more meaningful. Vegetation types that were identified in 2011 with TWINSPAN classification (Klimkowska et al. 2011) were used in the analysis (see Supplement D for typology).

Vegetation composition was analysed using multivariate analysis with Canoco 4.5 for Windows software (Leps and Smilauer 2003). In these analyses, which are based on ordination techniques, the similarities and differences in vegetation composition are analysed. The development of the vegetation was analysed for the relation to environmental factors and for changes over time. Species abundance data and the available environmental variables data were used. For this analysis, the abundance data were reclassified into percentage cover (see table in Supplement C) without any further transformation. The statistical significance of the change over time was tested. All relevés (2011, 2012, 2015) were analysed together. The data matrix consisted of 96 samples and 129 species. Weighting of species or samples was not used. A detrended correspondence analysis (DCA) was performed for data exploration. For testing the significance of the environmental variables (gradients), subsequent canonical correspondence analysis (CCA) was performed.

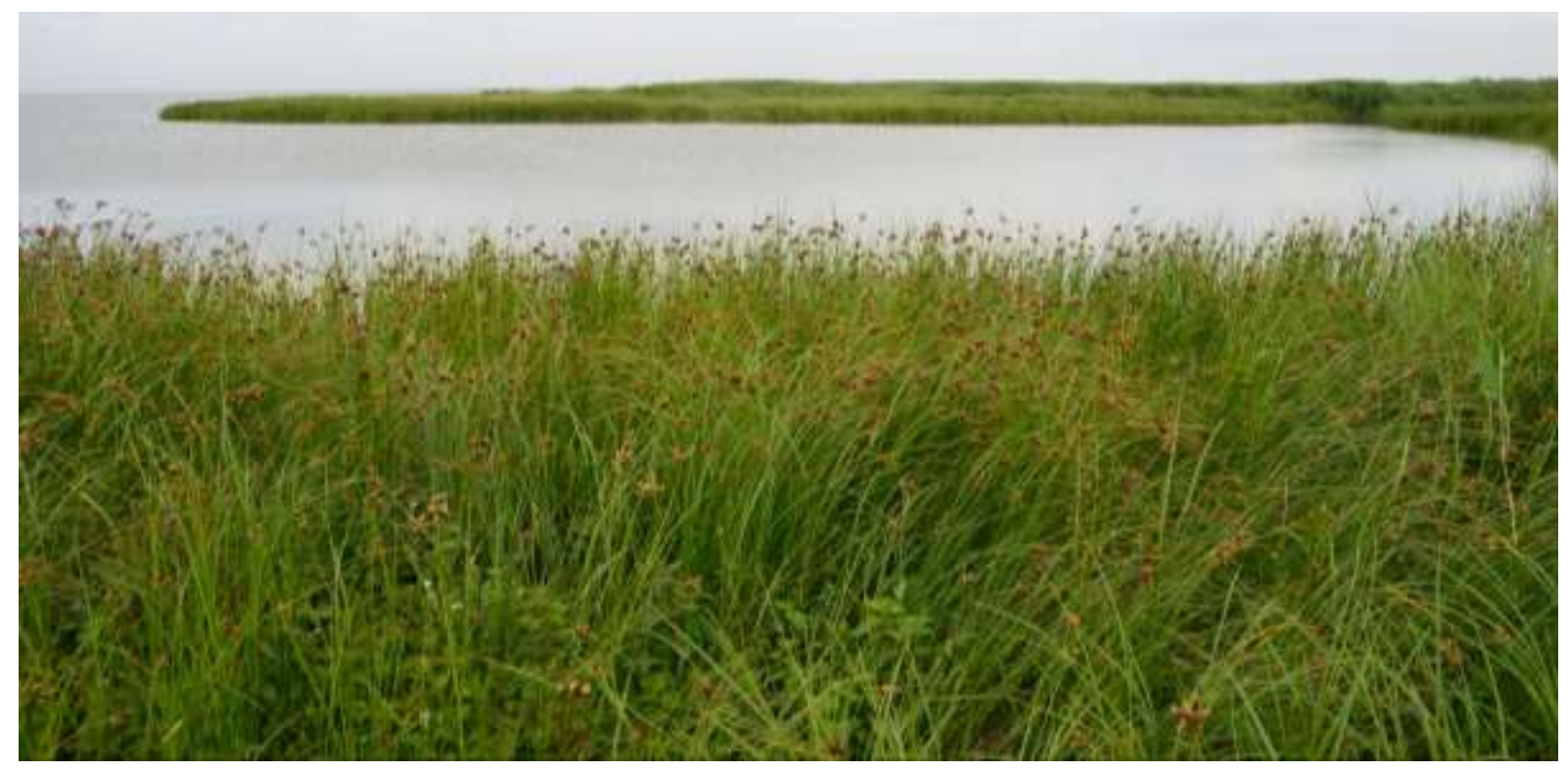

Tall vegetation on the lakeshore (C) A. Klimkowska 2015 


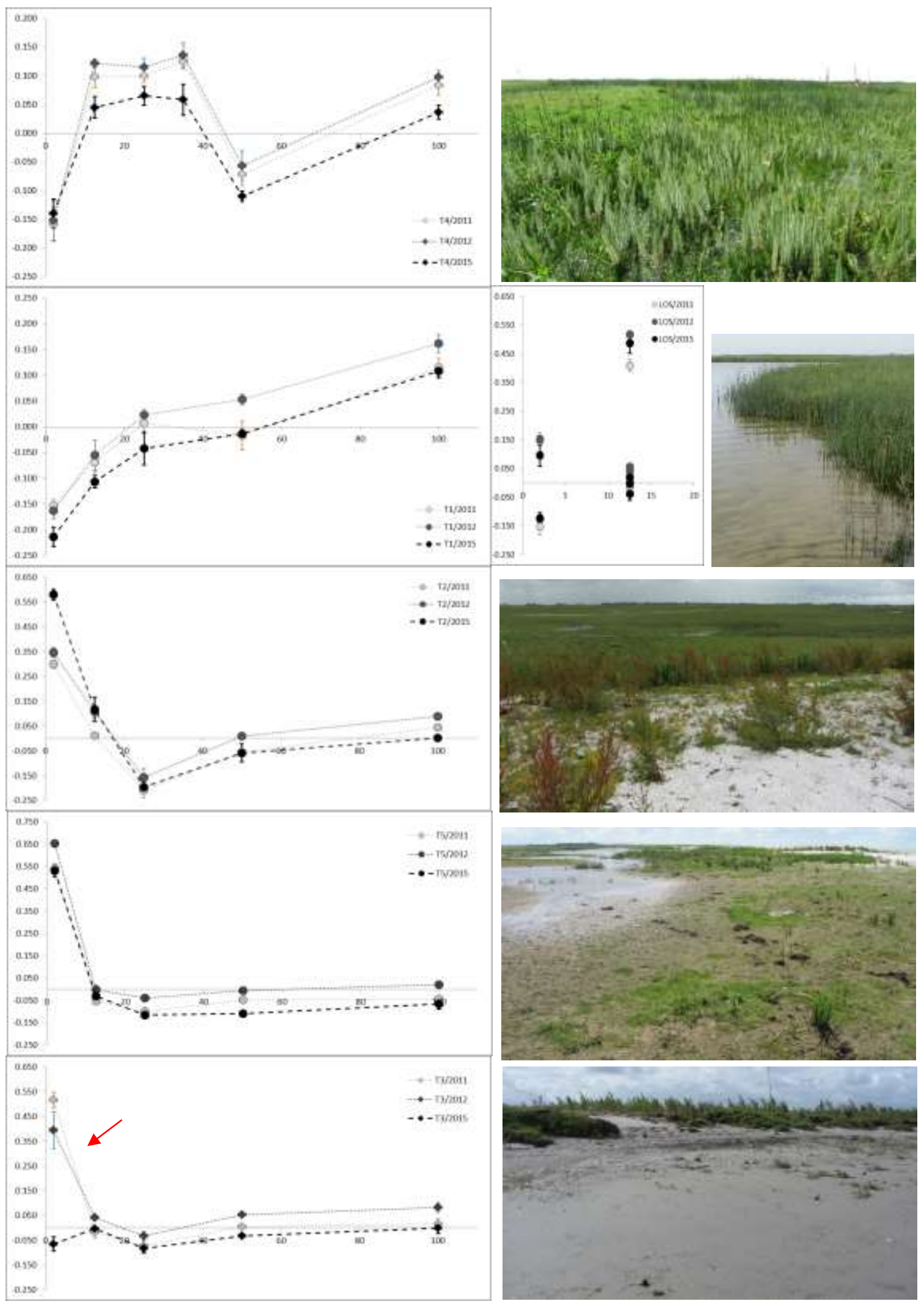

Figure 4.1: The transect profiles, together with photo impressions. The XY axes denote the distance from the shoreline and the altitude in meters above/below NAP, respectively. The average elevation of plots is shown (mean of 5 measurements, vertical error bars indicate $\pm S D$ ). 


\subsection{GEOMORPHOLOGY OF THE TRANSECTS AND VEGETATION ZONATION}

Processes of erosion and sedimentation affect the landscape of the Workumerwaard. It is characterized by sand and shell banks as well as creeks and shallow water pools. The pattern of former drainage ditches (major channels and smaller ditches) is still visible. Hydrological factors have a strong impact on the formation of the vegetation zonation. In the presented data, the role of hydrology was reflected by the elevation of the land as the lake water levels are kept artificially stable.

The northern part of the area is characterised by a rather narrow strip of foreland, marshy coast and vegetation with a diverse structure: patches of tall vegetation (reed and rushes), short and speciesrich vegetation, and some formation of shell banks (e.g. on island and in a distance from the shoreline). Wetland vegetation can be found near the shoreline and in the lower places, with water levels close to the soil surface or permanently inundated (transect 1 and 4 ). Further, away from the shoreline the summer water levels are $10-20 \mathrm{~cm}$ below soil surface. The average Lake IJssel water level in summer is $-0.20 \mathrm{~m}$ NAP.

The southern part is characterised by a broader zone of foreland with short vegetation (wet grasslands). Due to anoxia in the root zone and soil erosion in shallow puddles, formation of shallow pools takes place, with relatively large areas of an almost bare soil and germination of pioneer species. In the southern part, near the shoreline, a zone with shell banks can be found (transects 2, 3 and 5). Continuous processes of erosion, washing over and re-deposition of the material maintain the shell banks. This is a dynamic and shifting zone, providing important breeding habitats for birds. Without sufficient dynamics these banks are being overgrown by tall and ruderal species e.g. Tripleurospermum maritimum, Rumex species, Urtica dioica, Angelica archangelica, Epilobium hirsutum). As the banks are on the lakeshore and are not fixed by plant roots, there is a risk that with extreme storms and strong wave erosion large stretches of the banks can be washed away. Main observations were (Fig. 4.1):

- An overall slight decline of the elevation on two transects with marshy vegetation near the shoreline (Transect 4 and 1), except for a few plots where no change was observed;

- None or negligible changes in the elevation on the scattered plots near the dam;

- The elevation of the shell banks did not change (transect 5) or increased (transect 2), while the plots just behind the shell banks did not change;

- On the transect 3 (most southern) the shell bank moved some meters inland: the first plot on the transect was now located on a narrow beach in front of the shell bank (indicated with a red arrow on Fig. 4.1);

- The elevation of the plots further inland has decreased (zone with formation of the shallow pools), indicating soil erosion, most likely due to anoxia in the root zone, poor root development, soil washout during inundation and a high grazing pressure with frequent trampling by cattle. This is a negative development, as it makes large section of foreland susceptible to further erosion and it reduces and limits the resilience of the area. 


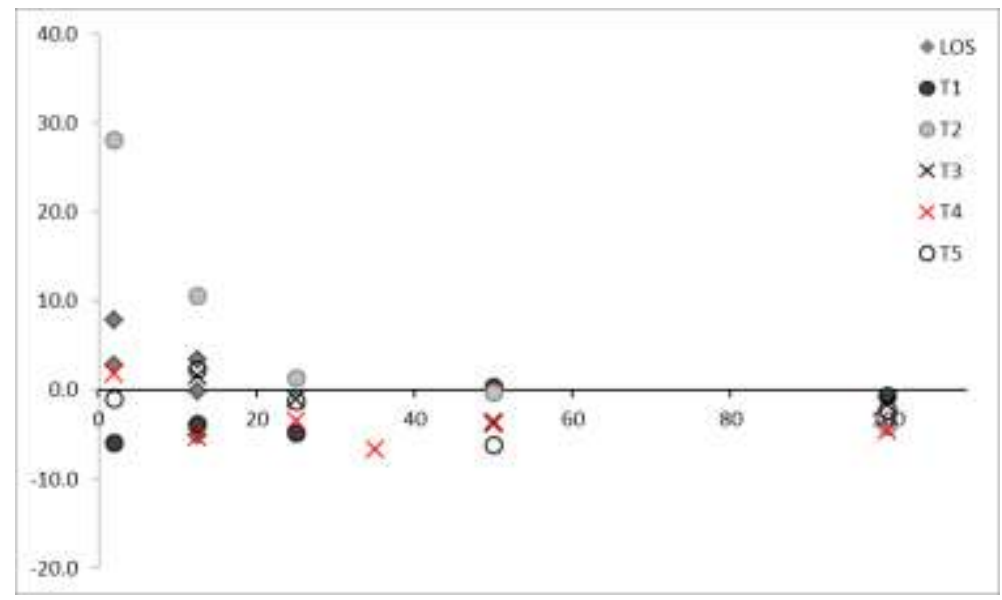

Figure 4.2: The difference in altitude between 2011 and 2015 plotted per transect. The XY axes denote the distance from the shoreline and the difference in height in $\mathrm{cm}$, respectively. The first plot on T3 (closest to the shore) is not marked. LOS indicates the scattered points near the dam.

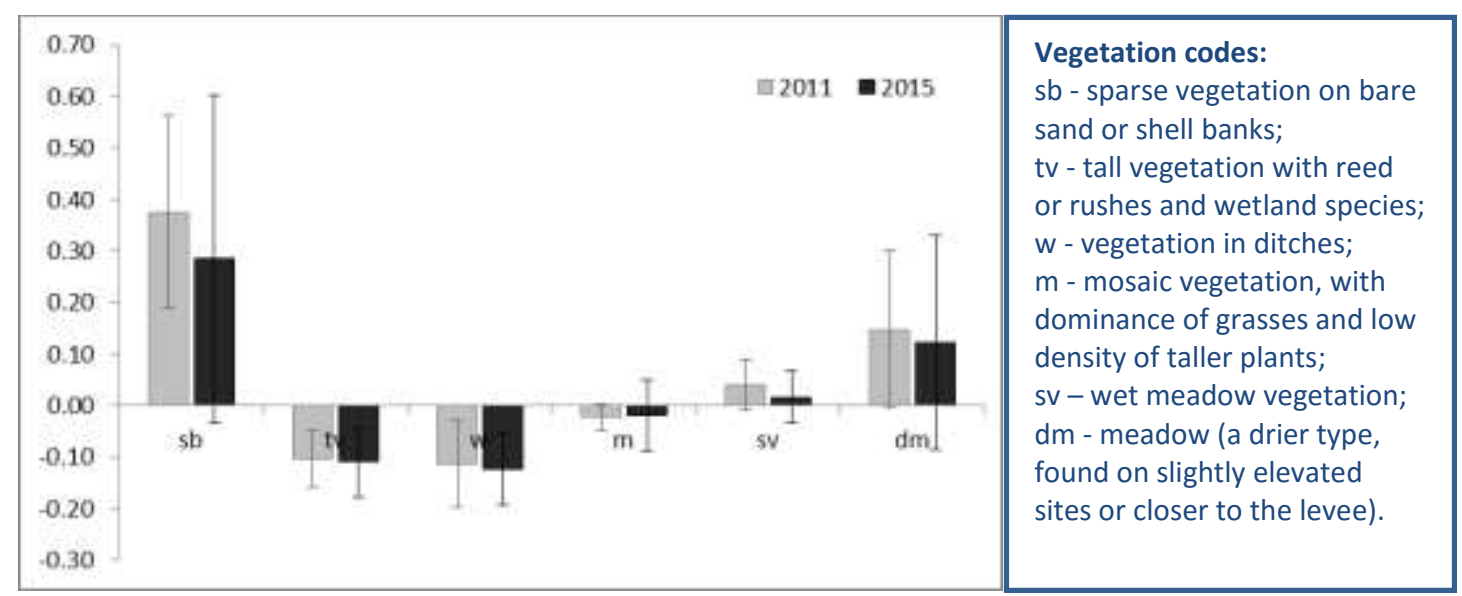

Figure 4.3: Elevation in meters ( \pm NAP) of the six vegetation types in 2011 and 2015. Mean $\pm S D$, denoted with error bars, is presented.

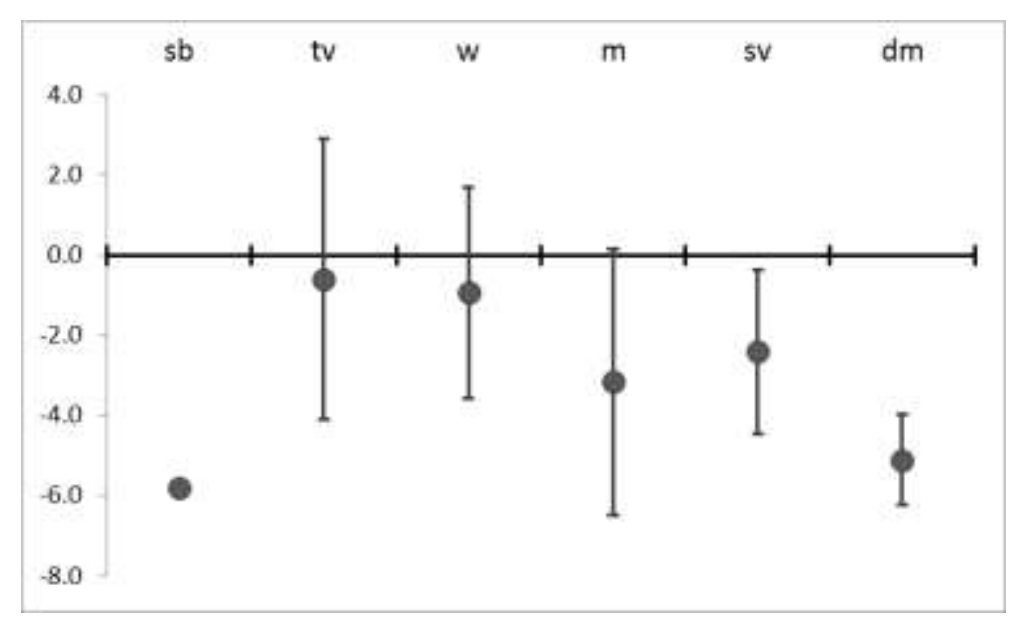

Figure 4.4: The difference in altitude (in cm) between 2011 and 2015 for each vegetation type. Mean $\pm S D$, denoted with error bars, is presented. Information for sb is not plotted, due to large variation. 
The elevation of each vegetation type (Fig. 4.3) and the difference in altitude between 2011 and 2015 per transect (Fig. 4.2) and per vegetation type (Fig. 4.4) were presented. The difference in altitude was calculated from the average height of the plots (for each plot). In general, differences less than $3 \mathrm{~cm}$ are not reliable, due to accuracy limitations. Graph 4.4 indicated a large variation within each vegetation type (information on standard deviation for shell bank vegetation ( $\mathrm{sb}$ ) is not plotted, due to large variation).

Transects 3 and 4 were 'control' transects, where no effect of the sand nourishment was expected. The elevation on the 'control' transects did not change (up to $20 \mathrm{~m}$ from shoreline), or decreased (> $20 \mathrm{~m}$ from the shoreline, mostly in sv and $\mathrm{dm}$ vegetation). The first plot on Transect 3 was an exception. It is located on a shell bank that shifted inland, resulting in a large drop of altitude (58 $\mathrm{cm})$. This exemplified process observed also elsewhere on the shore - loose material of shell banks are washed away or transported inland (by waves, during storms or by wind), exposing narrow beaches that are subjected to further erosion. The elevation on the 'effect' transects changed in an inconsistent manner: on Transect 1 and 5 it did not change or slightly decreased (up to 6-7 cm). There the situation was comparable to the control transects. On Transect 2 and on two scatter plots $(L 52, L 55)$, an increase of elevation was recorded, but only in a zone close to the shore (up to $20 \mathrm{~m}$ from the shoreline), with no change further inland. The relationship between the original elevation of the plots (measured in 2011) and the difference in height between 2011 and 2015 was examined (not shown), but no consistent relationships were found.

These results suggested that the elevation in the effect transects decreased as much as in the control transects, except for a few plots close to the shore on transect 2, in between transect 1 and 2 and on a former island in the vicinity of the dam. The increase of the elevation can be explained by "local" transport of sediment due to the continuous erosion and re-deposition of shell material or by formation of new shell banks, when material eroded elsewhere was redeposited by waves. Both of these processes were concluded in the field. As other monitoring activities have not found evidence for nourishment of sand deposition on the shore, it is not likely that the 'sand engine' contributed to an increase in elevation of the terrestrial vegetation. Moreover, the sand nourishment took place with a medium and fine sand fraction, while the plots close to the shore, where an increase occurred, were build up by shells and course sand. The transport and deposition of fresh sand within the vegetation next to the sand banks was observed in the field during strong wind ( $>5$ in Beaufort scale scale) (see photos below).

A local vegetation typology, with 6 types was developed based on data from 2011, using a TWINSPAN classification (Klimkowska et al. 2012), and was used in the current project (see brief description in the Supplement). Sparse vegetation of sandy banks (sb) was found in the highest elevations, while meadows (sv and $\mathrm{dm}$ ) were found in the intermediate sections (Fig. 4.3). The lower lying sections were occupied by a transition between meadow and wetland vegetation $(\mathrm{m})$ and in the lowest sites nearby the shore tall vegetation with reed (tv) or vegetation in the ditches (w) were found. The relations between the elevation and the vegetation types in 2011 an in 2015 were similar. On each transect, a zonation was observed with diverse vegetation types, related to the elevation. Therefore, the parameters are compared on the level of vegetation types (information on the plot level, to account for a natural variation in vegetation between sites, was used in multivariate analysis). 

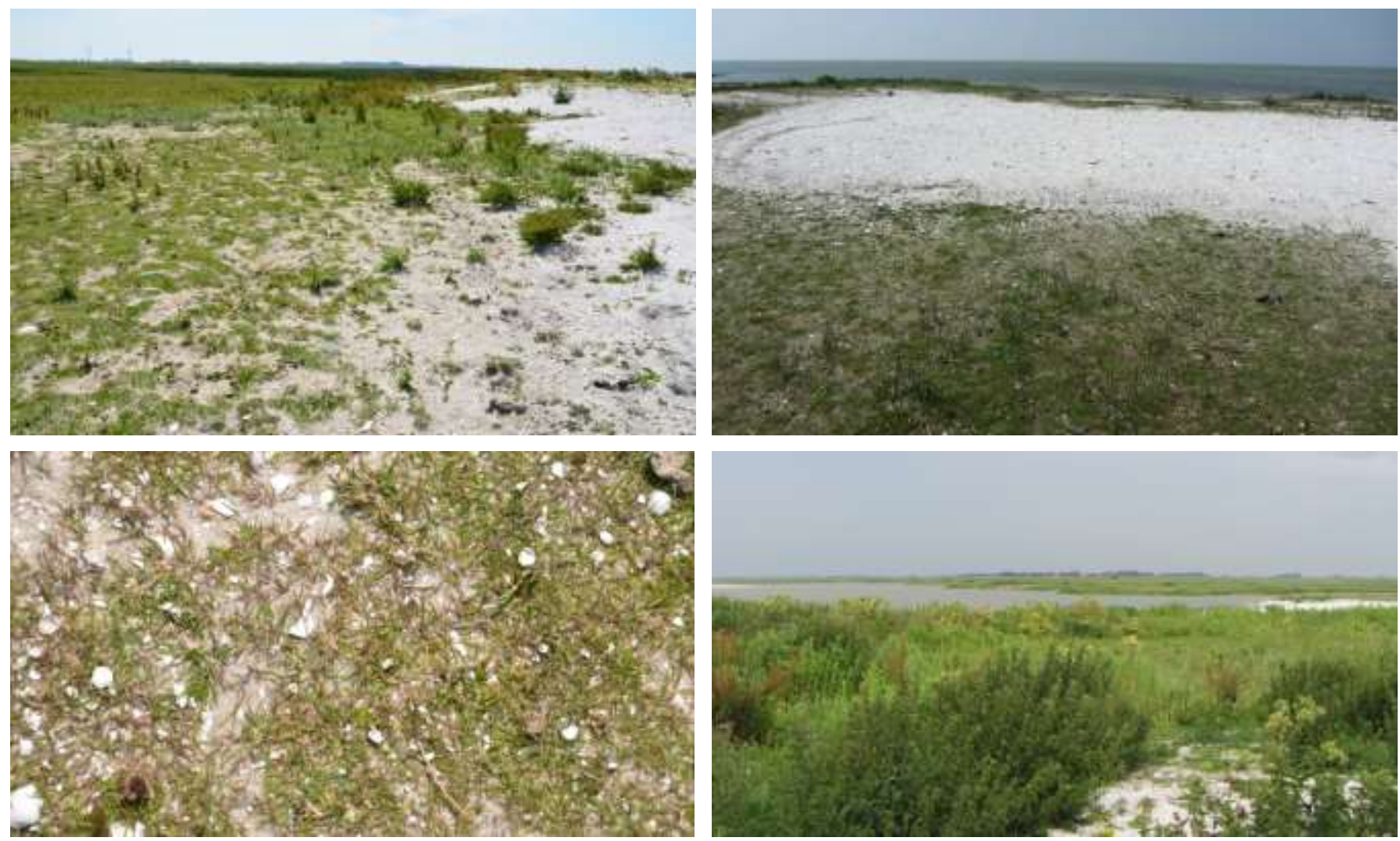

Fresh sand deposition within the vegetation just behind the sand banks (upper left and lower left in 2015, upper right in 2012) \& overgrowing of the sand banks with tall, ruderal vegetation (lower right, 2015) (c) A. Klimkowska 
On the level of vegetation types, significant differences (ANOVA single factor, p-value $<0.05$ ) in the elevation between 2011 and 2015 (including within-plot variation) were found for the drier meadow type ( $\mathrm{dm}$, all plots showed a considerable decrease), for wet meadow vegetation (sv, elevation declined with ca. $3 \mathrm{~cm}$, half of the plots showed a considerable decrease) and for the vegetation in ditches (significant, but negligible).

Changes in the wet meadows resulted most likely from the fact that these grasslands occupied an inland zone, where the formation of shallow pools and soil erosion took place. Due to the current water management, in this zone, a continuous degradation of grass swards and erosion of the thin organic soil layer (10-15 cm layer on the fine sand) takes place. In this zone, no natural processes take place that can result in an increase of the elevation, or accumulation of soil.

In tall vegetation (tv) and mosaic vegetation $(\mathrm{m})$, the majority of plots showed no considerable change, although some plots increase and some decrease. A discrepancy for the vegetation on the shell banks (the differences, calculated on each plot level ranged from +28.0 to $-58.0 \mathrm{~cm}$ ), comes from dynamic changes in this zone: shifting and eroding (or raising) of shell banks. In 2012, a slight increase of elevation was found; although no significant interaction with the vegetation type, (type of vegetation had no effect on the elevation increase). This was however close to the accuracy level of the measurements and was considered ecologically unimportant.

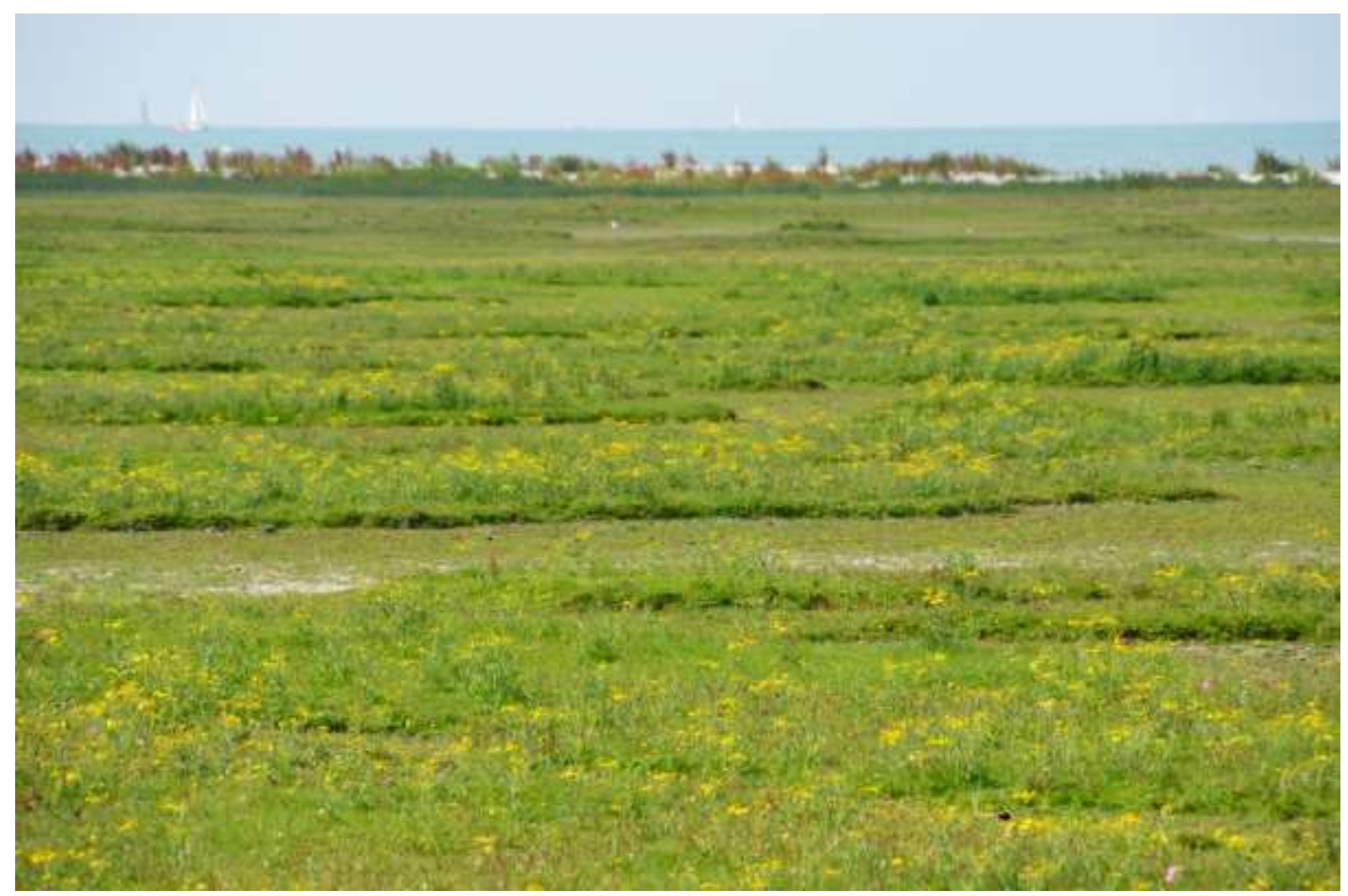

Formation of pools and puddles with 10-15 cm high erosion edges (C) A. Klimkowska 2015 


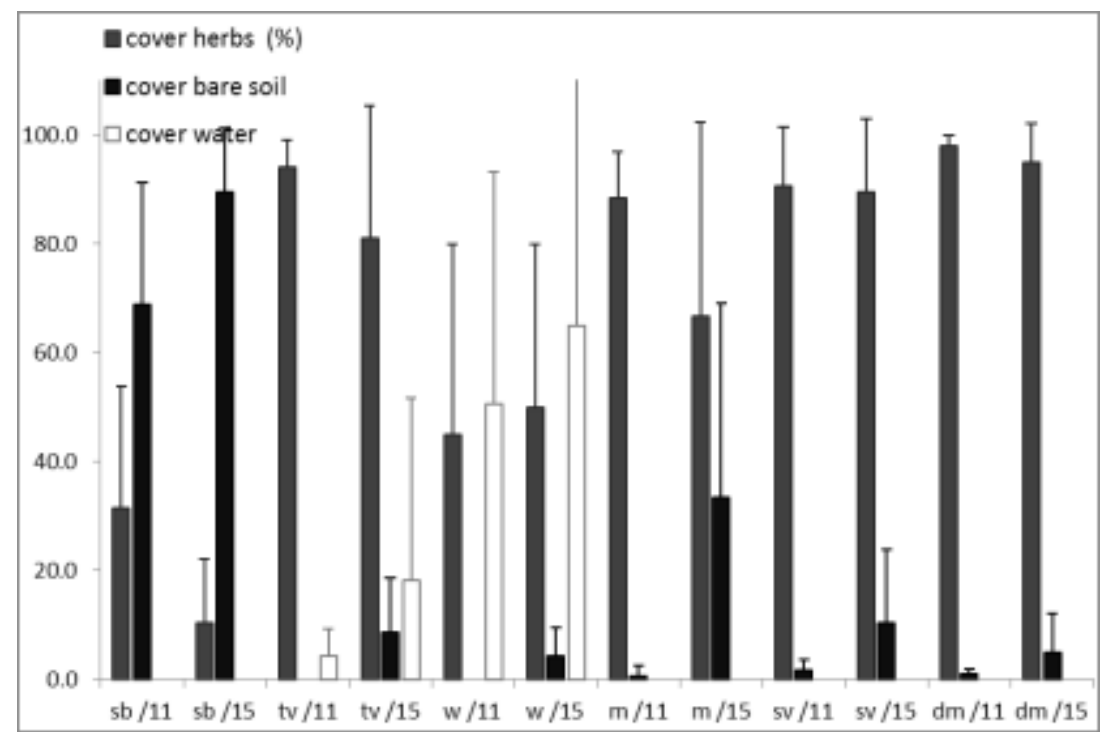
Vegetation codes:
$\mathrm{sb}$ - sparse vegetation on
bare sand or shell banks;
tv - tall vegetation
dominated by reed or rushes
and wetland species;
w - vegetation in ditches;
$\mathrm{m}$ - mixed (mosaic)
vegetation, with dominance
of grasses and low density of taller plants;
sv - meadow vegetation
(wet type);
dm - meadow (a drier type, found on slightly elevated sites or closer to the

Figure 4.5: Percentage cover of vascular plants, bare soil and water in the six vegetation types in 2011 and 2015 (average, error bars indicate +SD).

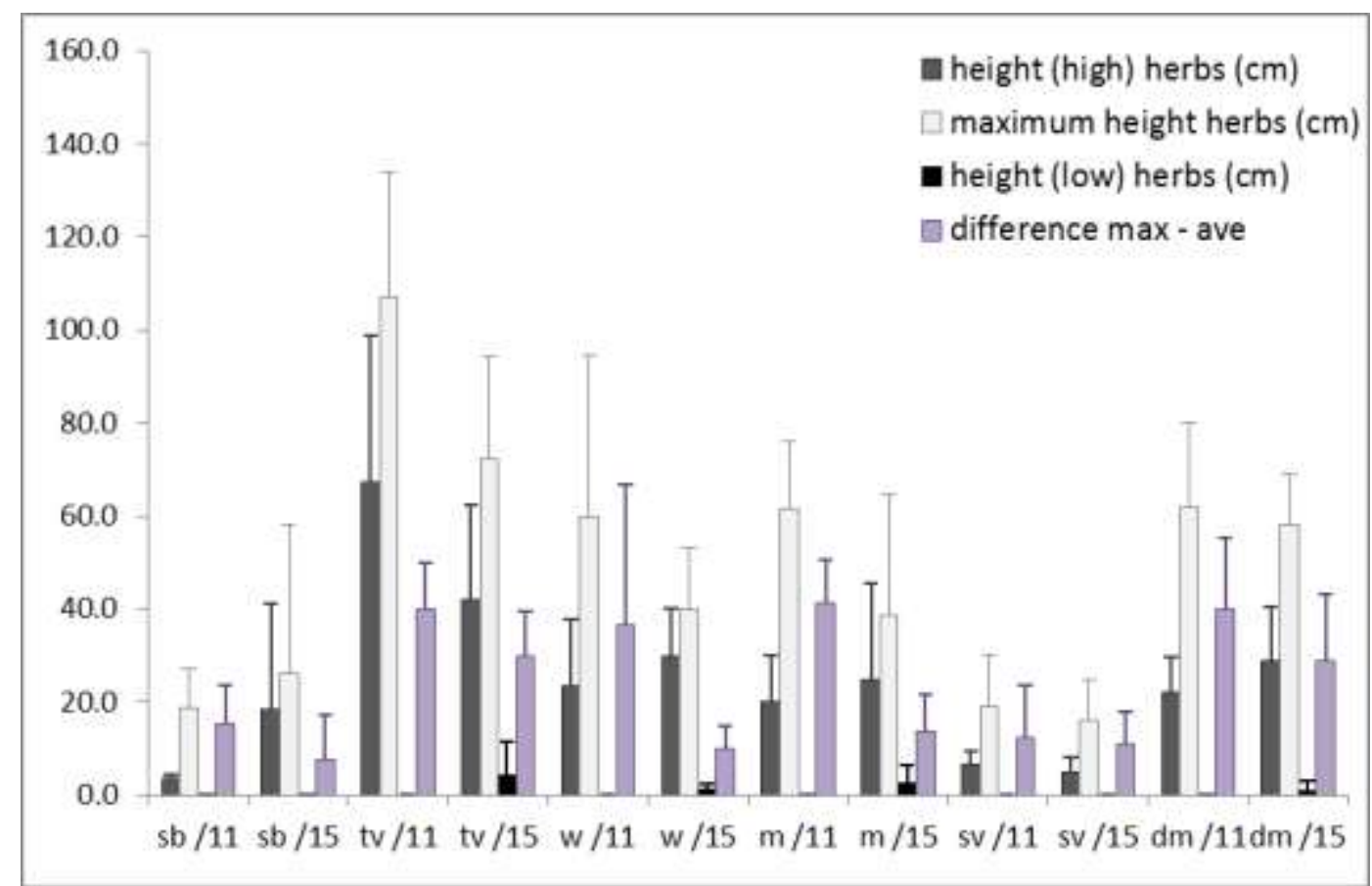

Figure 4.6: Average height of high herbs (where applicable also of low herbs), a maximum vegetation height and a difference between maximum and mean height of high herbs in the six vegetation types in 2011 and 2015 (average, error bars indicate +SD). 


\subsection{VEGETATION STRUCTURE}

For the vegetation structure, four parameters were most important: cover of plants, cover of bare soil (Fig. 4.5), average height and maximum height of plants (Fig. 4.6). Additionally the difference between maximum and average height of plants, which indicates the roughness of vegetation, is shown.

The lowest coverage of plants and a large proportion of bare soil $(60-100 \%)$ characterized the shell banks. In the channels and ditches the cover of vegetation was intermediate (ca. 50\%), while the rest of the surface was inundated. In other vegetation types, the cover of vegetation ranged from 75 to $100 \%$ and was overall similar. The difference in the percentage cover of plants (vascular plants) between 2011 and 2015 in each vegetation type was statistically tested, but no significant differences were found. In addition, the percentage cover of bare soil between 2011 and 2015 in each vegetation type was tested.

For mosaic vegetation and tall vegetation with reed or rushes, a significant increase in bare soil cover was observed (ANOVA single factor, $p$-value $<0.05$ ). Although the vegetation structure varied, the differences were not clearly reflected in the average and maximum vegetation height (Fig 4.6). No significant differences between 2011 and 2015 in these parameters were found. This was probably due to a large variation within vegetation types and a layered structure of the vegetation: e.g. in meadows the main plant layer is relatively low, but taller plants were also present, although with a low abundance.

Vegetation roughness was the highest in the tall vegetation, intermediate in vegetation in ditches; mixed (mosaic) vegetation and in drier meadow type and lowest in sparse vegetation on shell banks and short meadow vegetation (wet type). The difference between the highest plants and an average height of (high) herbs indicated the homogeneity of the vegetation. In general, sparse vegetation on shell banks and wet meadow vegetation were rather uniform, while the other vegetation types were more heterogeneous. There seems to be a decrease of this heterogeneity from 2011 to 2015 for mosaic vegetation and vegetation in the ditches. In the mosaic vegetation, it might indicate an actual change in the vegetation structure. In terms of the maintenance of the habitat quality for birds, this would be a negative development: a layered structure of the vegetation is a feature of valuable foraging habitat for young birds.

Vegetation structure depends on the species composition and is strongly affected by grazing. After an intensive grazing season in 2011, the cover of bare soil increased sharply in the following year, in all vegetation types. This can be explained as an effect of trampling. In addition, the frequency of occurrence of pioneer species, that require gaps in vegetation and bare soil for germination have increased between 2011 and 2012 (Klimkowska et al. 2012). At the same time, the vegetation roughness (height and heterogeneity within vegetation) has decreased from 2011 to 2012, especially in meadows (wet and dry) and mosaic vegetation. Keeping in mind the system of Workumerwaard, this was most likely due to grazing by cattle. The comparison between 2011 and 2015 did not show similar changes, probably due to a varying grazing pressure and other processes interacting. 


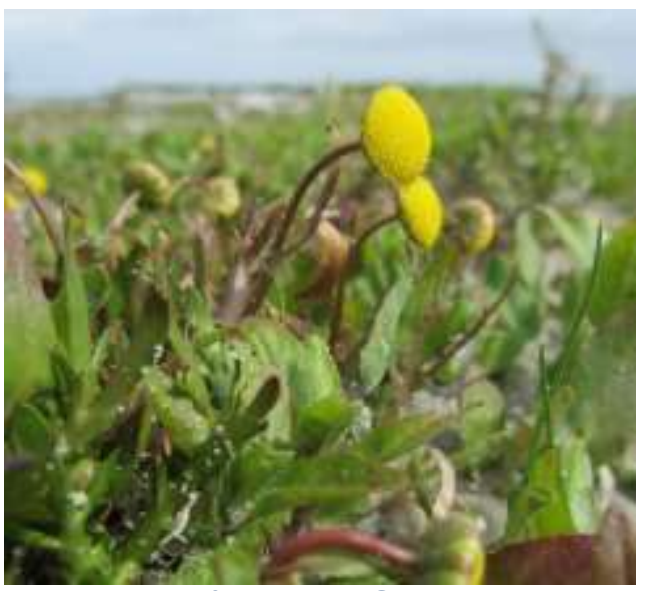

Cotula coronopifolia 2012 (C) A. Klimkowska

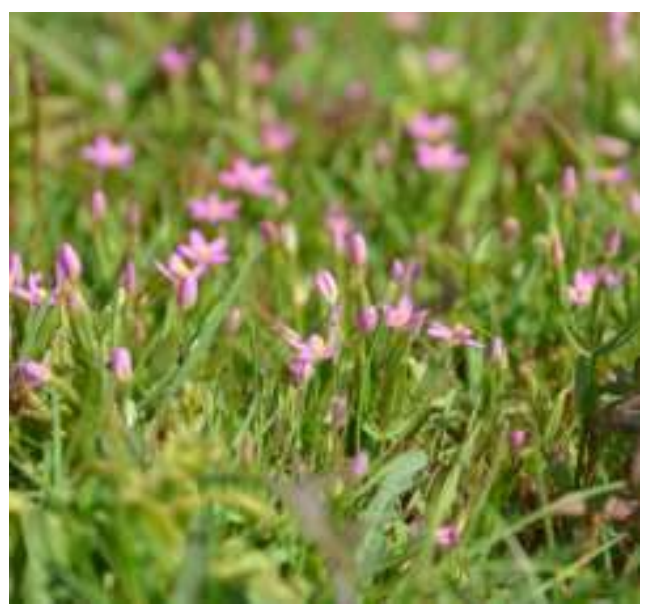

Centaurium pulchellum 2015 (c) A. Klimkowska Samolus valerandi 2015 (c) A. Klimkowska

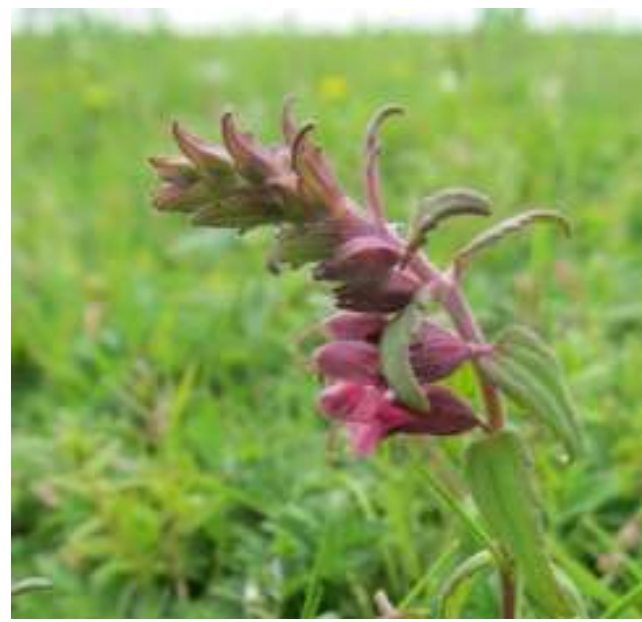

Odontites vernus 2015 (C) A. Klimkowska

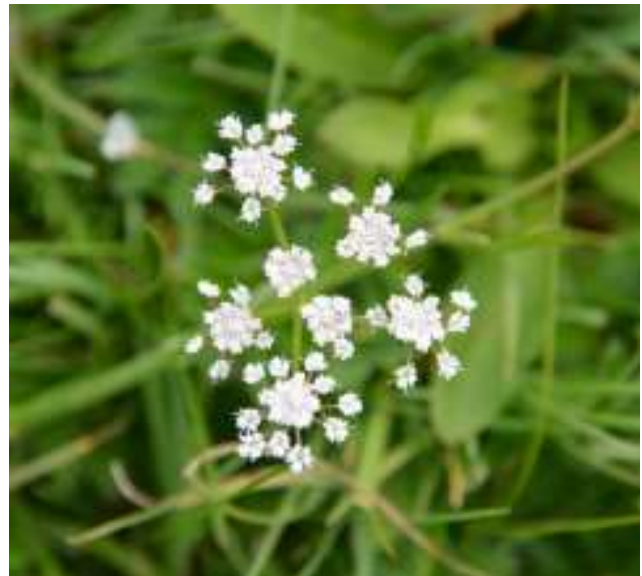

Oenanthe lachenalii 2015 (C) A. Klimkowska
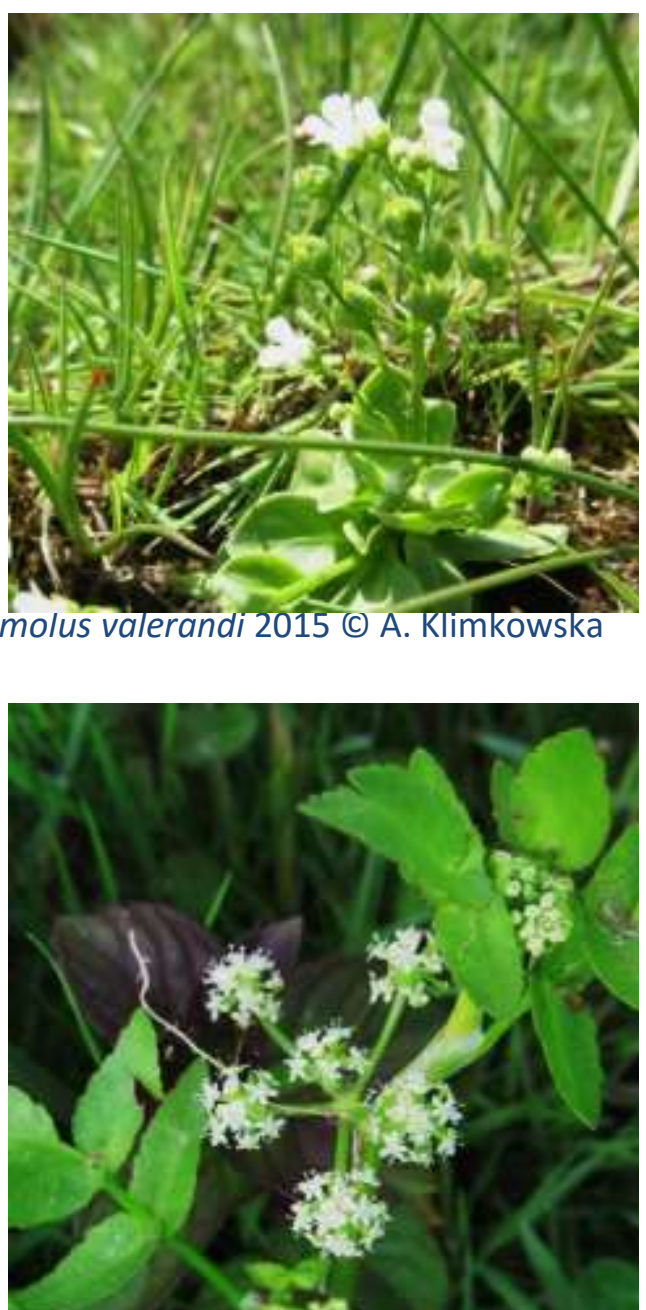

Apium nodiflorum 2015 (c) A. Klimkowska 
The vegetation of Workumerwaard is heterogeneous, moderately species-rich and represented an ecologically interesting gradient that is affected by hydrological conditions, as well as by erosion, sedimentation and locally intensive grazing. It consisted of several types of grassland and wetland vegetation, and included species indicating fresh and brackish conditions. In total 32 relevés were recorded in 2015, with 105 species.

The general impression of the vegetation in 2015 was similar as in 2011/2012: there were patches of tall vegetation with reed (Phragmites australis) and bulrush (Schoenoplectus tabernaemontani). Some elements of the vegetation resembled brackish conditions: a number of indicator species for salt or brackish conditions were found in the area. In and along the creeks and northern shoreline the vegetation consisted of Schoenoplectus tabernaemontani and Bolboschoenus maritimus, typical species for coastal vegetation of dune valleys. In the short vegetation species such as Juncus gerardii, Glaux maritima, Spergularia marina, Oenanthe lachenalii, Pulicaria dysenterica, Carex distans, $C$. otrubae were found. Wet meadows were dominated by Agrostis stolonifera, Potentilla anserina and Carex nigra. The old creeks and ditches were occupied by Mentha aquatic, Hippuris vulgaris, Veronica catenata.

Grazing had an impact on the vegetation development. Cattle is ranging over the entire gradient and grazing the reed patches. Grazing by horses was present in 2012, but later stopped. Horses avoided wetter sides and grazed mainly the drier meadows and on the levee. Trampling by cows allows small, pioneer species to endure in the vegetation. However, some locations were heavily trampled by cattle, which prevented the development of a grass sward and contributed to greater erosion. In addition, the presence of geese in winter until early spring is an important factor; geese favourably feed on freshly growing short shoots of Festuca rubra, Juncus gerardii or Agrostis stolonifera. The area hosts a large population of overwintering geese (Branta leucopsis, Anser anser), varying between $10000-30000$ birds (estimated for the entire meadow complex inside and outside the summer levee). There is a growing breeding geese population in the area, increased from c. 8000 since the 1990s. Moreover, geese tend to stay longer in the spring (in 2012 until the beginning of June) (per. comm. H. Pietersma, It Fryske Gea).

Concerning uncommon species, in 2015 a presence of Samolus valerandi (Waterpunge) was recorded and locally a high frequency of Apium nodiflorum (Groot moerasscherm), Eleocharis acicularis (Naaldwaterbies), Pulicaria vulgaris (Klein vlooienkruid) were observed. In addition, Cotula coronopifolia (Goudknopje) was observed, although much less frequent than in previous years.

In a detrended correspondence analysis (DCA) the first two ordination axes together explained $15.86 \%$ of variance in the species data (supplementary variables account for $37.3 \%$ ). All given environmental variables increased in the direction of the corresponding arrow. The gradient length was 4.18 on the first axis, which allowed the use of unimodal methods (i.e. DCA, CCA). 

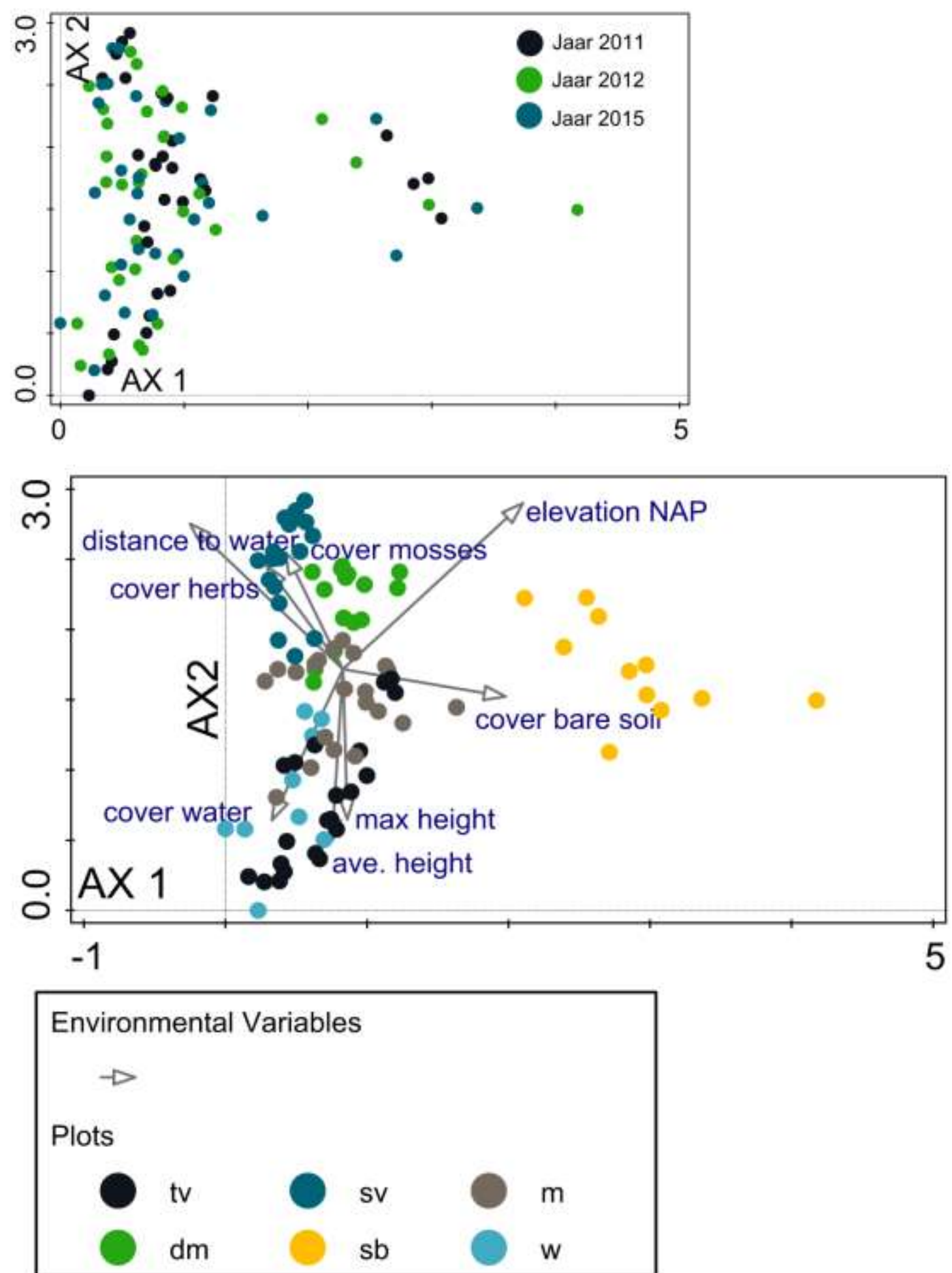

Figure 4.7: Sample plot of the DCA ordination of the vegetation (129 species, 96 samples) with supplementary variables (environmental gradients). Ordination explained $15.86 \%$ of variance in the species data on the first two axes cumulatively (eigenvalues: 0.4540 and 0.3120 , respectively). The upper graph shows a displacement of the sample scores over time. The lower graph shows a clustering of samples by vegetation types (colour symbols represent classification in 2011). 
The results were presented in Figure 4.7 and Figure 4.8. The vegetation did not change drastically over time, but, in general the vegetation types were separated (Fig. 4.7). The ordination showed that the vegetation on the sand banks (sb) was clearly different from the rest of the vegetation. The mixed (mosaic) type $(\mathrm{m})$ was overlapping with other types and tall vegetation and vegetation in the ditches were overlapping with each other. The environmental gradients were plotted passively (passively fitted to the species ordination), for easier interpretation of the results.

The horizontal axis mainly represented the contrast between the shell bank vegetation and other vegetation types, and was related to (high) cover of bare soil, and in general higher elevations. The vertical axis mainly represented a gradient from short vegetation and less wet conditions (upper part) to tall plants and overall more wet / inundated conditions (lower part). This was also apparent from the position of the species in Fig. 4.8.

In the 'constrained' CCA (Canonical Correspondence Analysis) analysis the first two ordination axes together explained $11.2 \%$ of variance in the species data (total variation 4.82896 , explanatory variables account for $20.8 \%$, adjusted explained variation is $15.5 \%$ ).

Table 2: Summary of statistics CCA.

\begin{tabular}{|llll|l|}
\hline Statistic & Axis 1 & Axis 2 & Axis 3 & Axis 4 \\
\hline Eigenvalues & 0.2814 & 0.2588 & 0.1995 & 0.1205 \\
\hline Explained variation (cumulative) & 5.83 & 11.19 & 15.32 & 17.81 \\
\hline Pseudo-canonical correlation & 0.8750 & 0.8718 & 0.8882 & 0.8444 \\
\hline Explained fitted variation (cumulative) & 27.96 & 53.67 & 73.49 & 85.46 \\
\hline
\end{tabular}

Six variables were found significant for the vegetation in the forward selection procedure (significance testing with Monte Carlo permutation test, 999 permutations). These were: elevation NAP of the plots (explained $5.4 \%$ of variability in the data, pseudo- $F=5.4, p=0.008$ ); distance to shoreline (explained $4.5 \%$ of variability, pseudo- $F=4.6, p=0.006$ ); cover of the bare soil (explained $4.2 \%$ of variability, pseudo- $\mathrm{F}=4.5, \mathrm{p}=0.008$ ); year of observation (explained $2.6 \%$ of variability, pseudo- $F=2.8, p=0.025$ ); cover of water (explained $2.5 \%$ of variability, pseudo- $F=2.8, p=0.009$ ); maximum height of plants (explained $1.6 \%$ of variability, pseudo- $F=1.7, p=0.02$ ).

Two variables - 'elevation NAP of the plots' and 'cover of water' were related to the hydrological factors and these were the most important for vegetation development. Since the hydrological parameters were not directly measured, these two variables are proxies for the wetness, and, consequently, for the anoxia conditions in the root zone. The variables: 'cover of the bare soil' and 'distance to shoreline' were related to the erosion and sedimentation processes.

Data on grazing pressure (animal density) or the effect of grazing (soil trampling), were not available, and thus not included in the analysis. The effects of grazing (soil trampling, removal of biomass, limiting growth of tall plants) can be derived from the cover of bare soil and the vegetation height. The variable 'Year of observation' indicated an effect of time and a change of the vegetation over time (related to third or fourth ordination axis). A variable 'maximum height of plants' was probably related to productivity of site and occurrence of the tall marsh species.

Summarizing, the variability of the vegetation was large. The explained variability was mainly due to hydrological conditions (associated to axis 1). Also grazing and other soil erosion factors were important factors shaping the vegetation. 


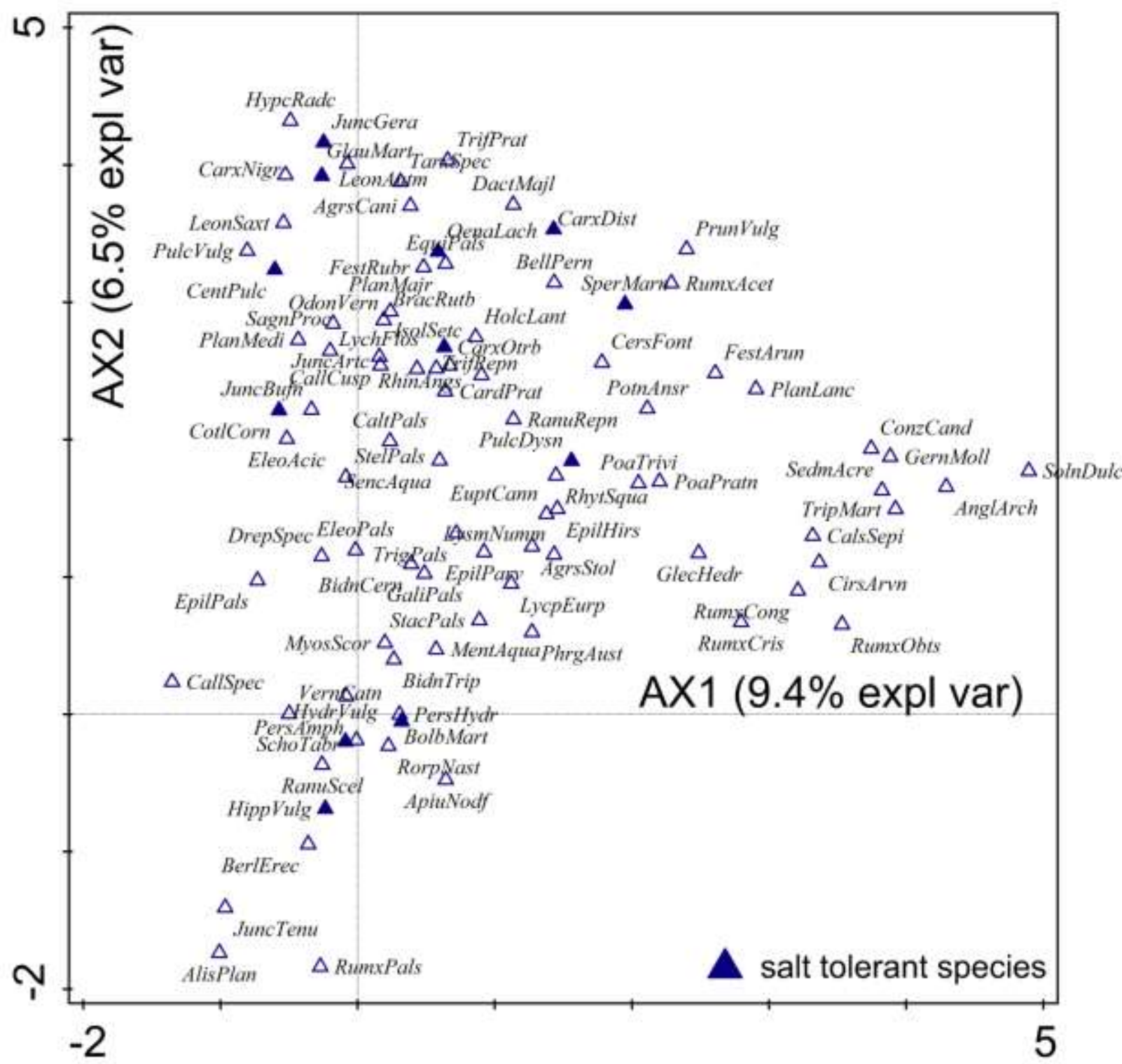

Figure 4.8: Species plot of the DCA ordination; 93 species best fitting the ordination were plotted for clarity. This plot has the same scaling as plot 4.7 and has a distance interpretation (the closer a species name is to a sample point, the higher is the probability to find it in that particular sample). Species names are the first four letters of the genus name and the first four letters of the species name. 

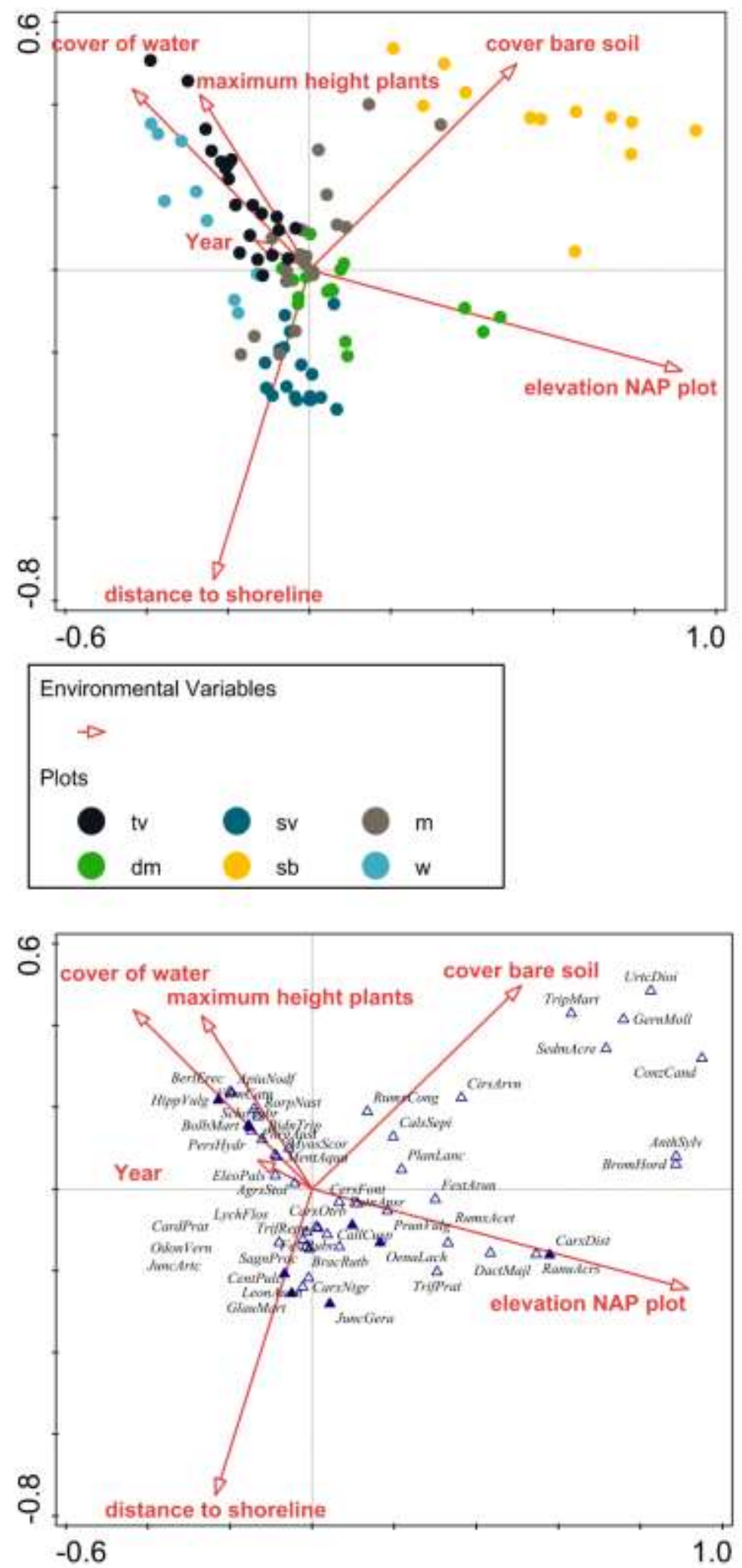

Figure 4.9: Samples and species plot of the CCA ordination (upper and lower graph, respectively, based on 96 samples, 129 species). In the lower graph, 50 bet fitting species are plotted. Statistical summary in Table 2. 


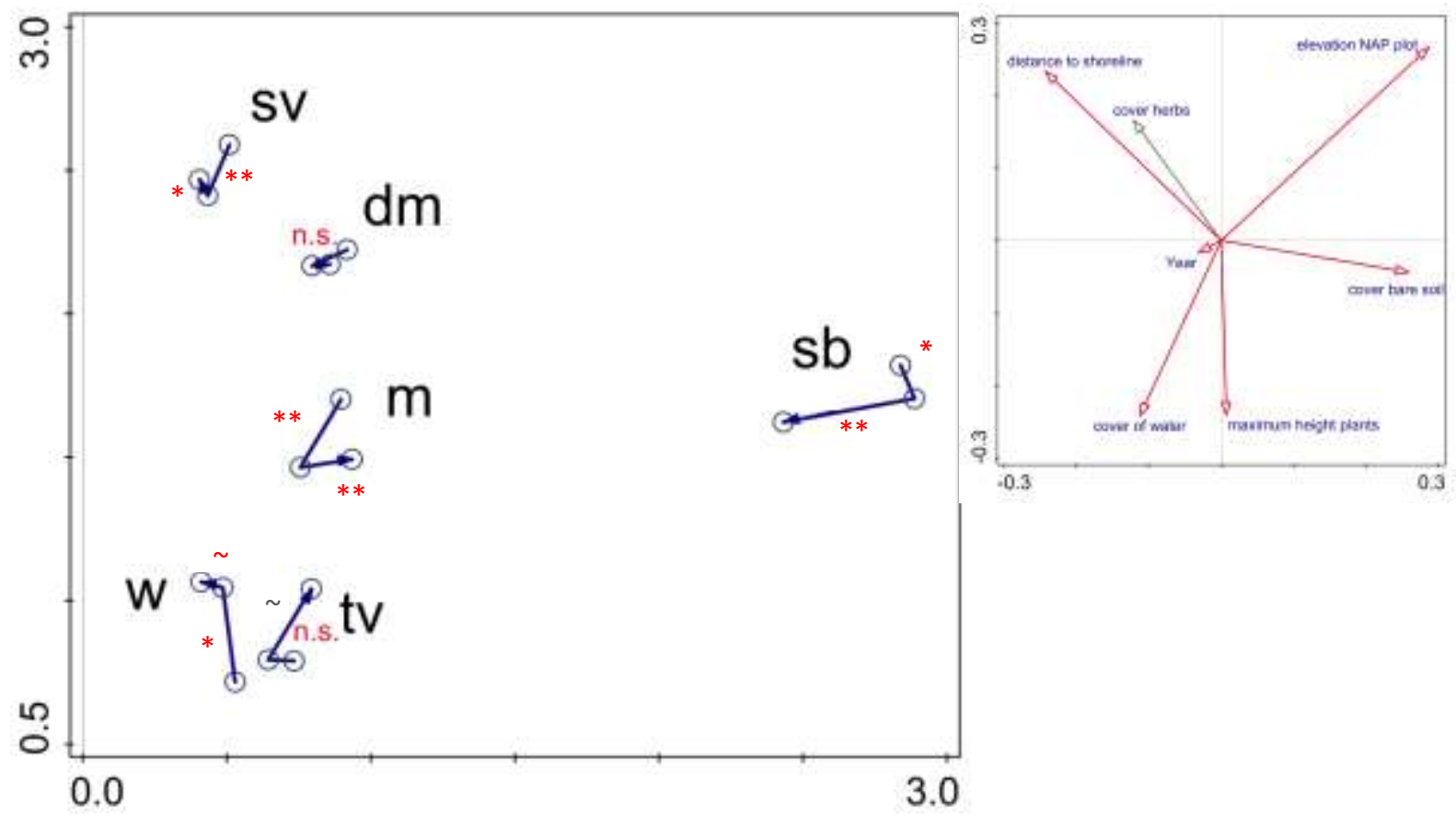

Figure 4.10: Displacement of the centroids per vegetation type over time (in DCA space). Significance of change over time: ${ }^{* *} p<0.01$; ${ }^{*} p<0.05 ; ~ p<0.07$; 'n.s.' not significant. A plot of the most important environmental gradients was supplemented (on the right side) to help an interpretation.
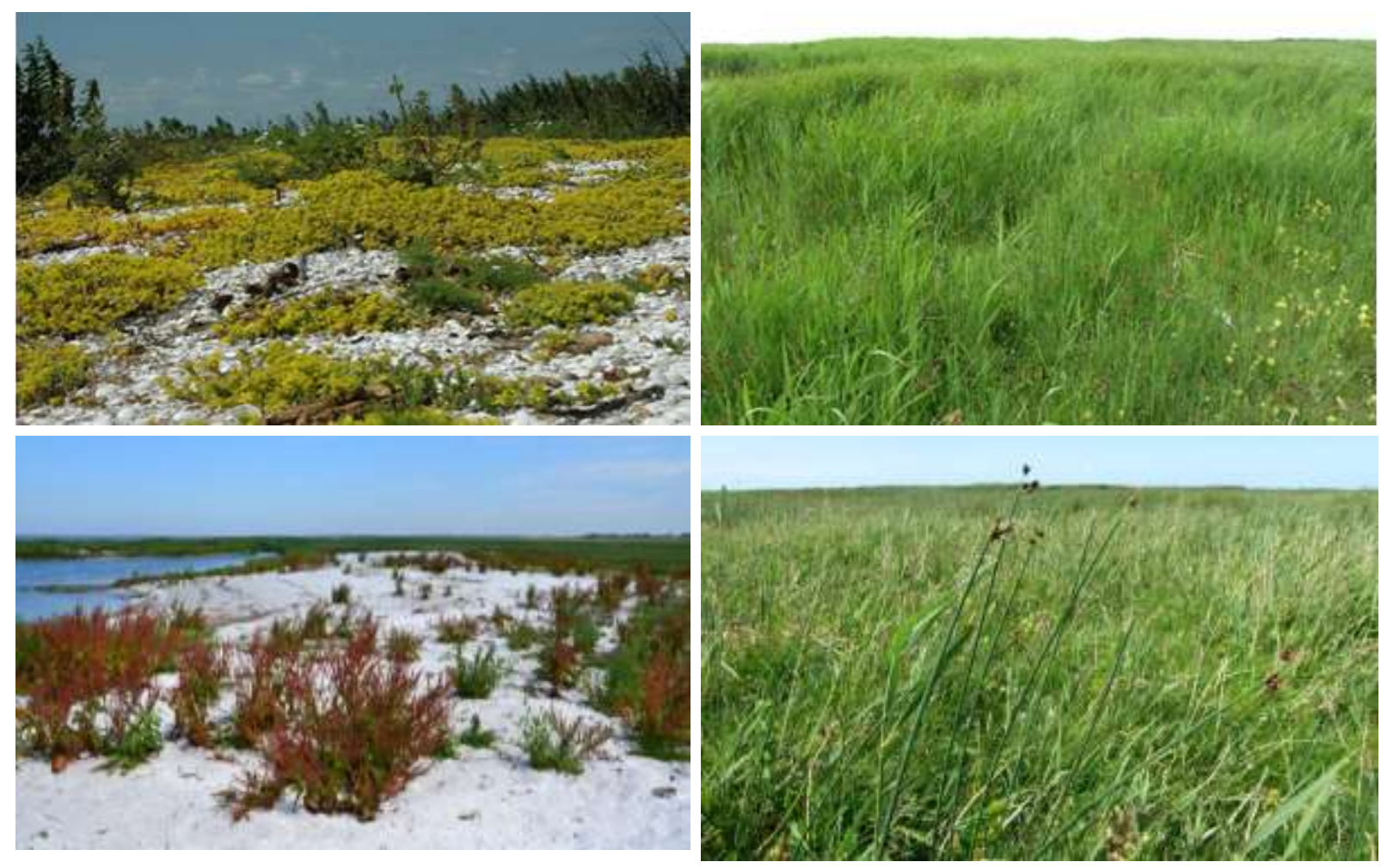

Scarce vegetation on the shell banks and tall vegetation with reed in 2011/2012 (top row) and in 2015 (bottom row) (C) A. Klimkowska 


\subsection{CHANGES IN VEGETATION COMPOSITION BEFORE AND AFTER ESTABLISHING THE SAND NOURISHMENTS}

Change of the vegetation over time was tested in two-step CCA analyses. In the first step, CCA analysis was used to test the overall significance of the change. In this test, the PQs were used as covariables to account for differences between plots and the factor of time was used as the only effect variable. The change was significant (results of Monte Carlo Permutation Test pseudo-F=3.9, $\mathrm{P}=0.001$, after 999 random permutations, partial variation 2.07691, explanatory variables account for $5.8 \%$, adjusted explained variation $4.3 \%$ ). Next, the significance of the change per vegetation type was determined in a second CCA analysis. This is accomplished by addition of interaction terms (vegetation type*year) to a model and testing the significance of the differences. Here, some changes in the vegetation were significant and others not (Table in Supplement E for details, partial variation 2.07691 , explanatory variables account for $30.4 \%$, adjusted explained variation $14.3 \%$ ).

The results were presented in Fig. 4.10, which summarized the displacement of the centroids per vegetation type (plot can be overlaid with Figs. 4.7, 4.8). The temporal changes in the vegetation (indicated by the length of the arrows) were small compared to the differences between vegetation types (indicated by the distance between the arrows). Significant changes were found in the vegetation of the shell banks (sb), mosaic vegetation $(\mathrm{m})$, and the vegetation of wet meadows (sv), and, to a lesser extent in the vegetation of ditches (w). No change was found in the vegetation of drier meadows type $(\mathrm{dm})$ and tall vegetation with reed (tv). No general trend in the diagram can be distinguished, and the direction of change differs per type.

In the case of the vegetation shell banks, the change was towards the left side of the diagram, which can be interpreted as related to a decrease of the percentage bare soil and somewhat related to a decrease of the elevation. This may indicate an ongoing establishment of the vegetation on some banks (undesirable) and erosion and washing away of vegetation on the others.

The direction of change for $\mathrm{sv}$ and $\mathrm{m}$ was towards the lower left part of the diagram. This can be related to a decrease of elevation, and for mosaic vegetation a slight increase of the cover of bare soil. This most likely indicated a response to the soil erosion, i.e. replacement of grasses by pioneer species (e.g. Juncus species).

In the wetland vegetation in the ditches and the marsh vegetation dominated by reeds and rushes, the direction of the change was upwards. This is related to a decrease of the cover of water in the plots, decrease in the height of the plants (both maximum and mean height of tall herbs) and an increase of the elevation. This most likely indicates a slow filling up of the ditches with fine sediments and litter. The lower vegetation height (shoots of Phragmites australis, Schoenoplectus tabernaemontani, Bolboschoenus maritimus or Hippuris vulgaris) may indicate an effect of grazing, strongly limiting the tall plants, but can also be related to a delayed phenology in 2015 (cold spring) or less eutrophic conditions. Considering the high nutrient availability in the Workumerwaard system, the last explanation is least likely. 


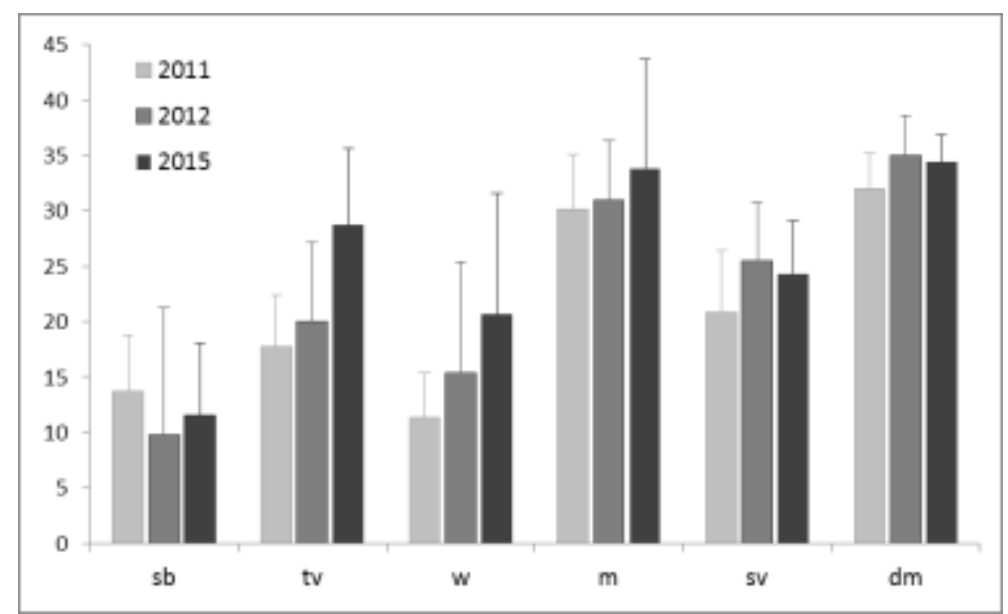

Figure 4.11: Species richness per plot $\left(4 \mathrm{~m}^{2}\right)$ in the six vegetation types in 2011, 2012 and 2015. The $\mathrm{X}$-axis denotes vegetation types; the $\mathrm{Y}$-axis represents the no. of species (mean $\pm \mathrm{SD}$ ).
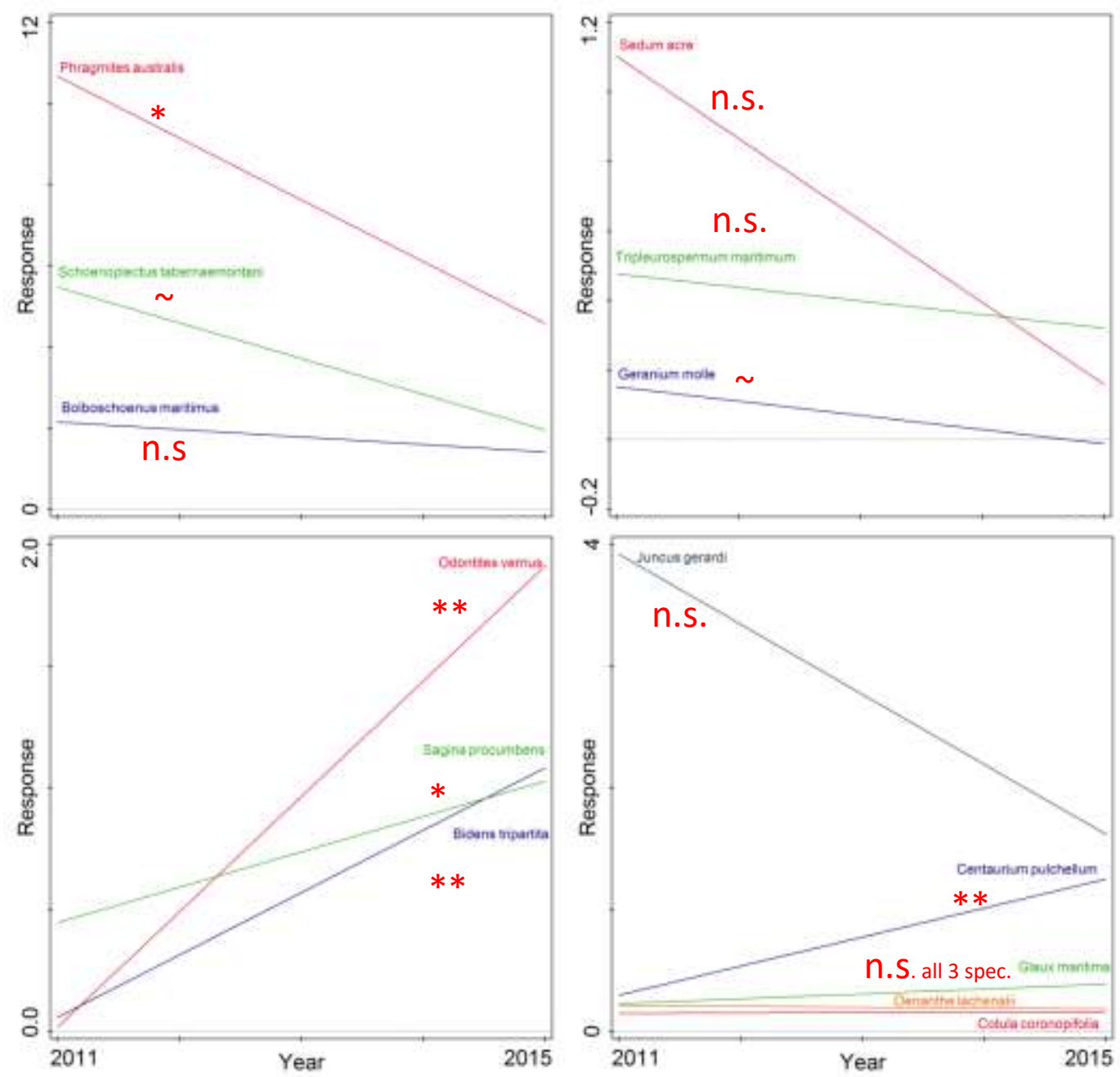

Figure 4.12: Species response over time for four groups of species. Response based on the GLM models, generated in Canoco for Windows software. Significance of change over time: ${ }^{* *} p \leq 0.001$; $p \leq 0.05 ; \sim p \leq 0.1 ;$ n.s. not significant. 
Species richness strongly varied between vegetation types, but did not considerable change over time (Fig. 4.11). This was also concluded in 2012. In the vegetation of shell banks, the number of species was lowest (usually below 10 ). The highest species numbers per plot (up to 40 species) were observed in the mosaic vegetation and in the drier meadow variant (with orchid Dactylorhiza majalis and other species occurring in Calthion palustris alliance or with species of saline meadows). In general, there was a slight trend for an increase in the species number over time, but a significant increase was found only in tall vegetation (tv) (ANOVA single-factor, $F=5.9, p=0.01$ ). A slight increase in the species numbers in the mosaic vegetation and drier meadow type $(\mathrm{m}, \mathrm{dm})$ was observed already between 2011 and 2012 .

The response of selected species, based on occurrence and abundance of species (Fig. 4.12), indicative for specific environmental conditions, supported earlier conclusions. A sharp increase in species of wet, bare soil after disturbance was observed (Odontites vernus, Bidens tripartita, Sagina procumbens), similarly as described in 2012. Species indicating brackish conditions did not change substantially, exempt for Centaurium pulchellum, which increased significantly. A numerous occurrence of this species was observed mainly on bare, moist soils. Overall, the occurrence of salttolerating species did not change over time (Juncus gerardi, Glaux maritima, Cotula coronopifolia, Oenanthe lachenalii). Some tall plants of wet conditions (Bolboschoenus maritimus, Phragmites australis, and Schoenoplectus tabernaemontani) showed a moderate decrease, although this was significant only for reed. This is probably related to the impact of cattle grazing. In 2012, a slight increase of frequency in tall wetland plants was observed, associated with less intense grazing. Species of dry and bare sand banks (Tripleurospermum maritimum, Geranium molle, Sedum acre) showed a decline, although not significant. A decrease for these species was also identified in 2012.

Limited trampling results in 'safe site' for plant germination and establishment in hoof print (C) A. Klimkowska 2012

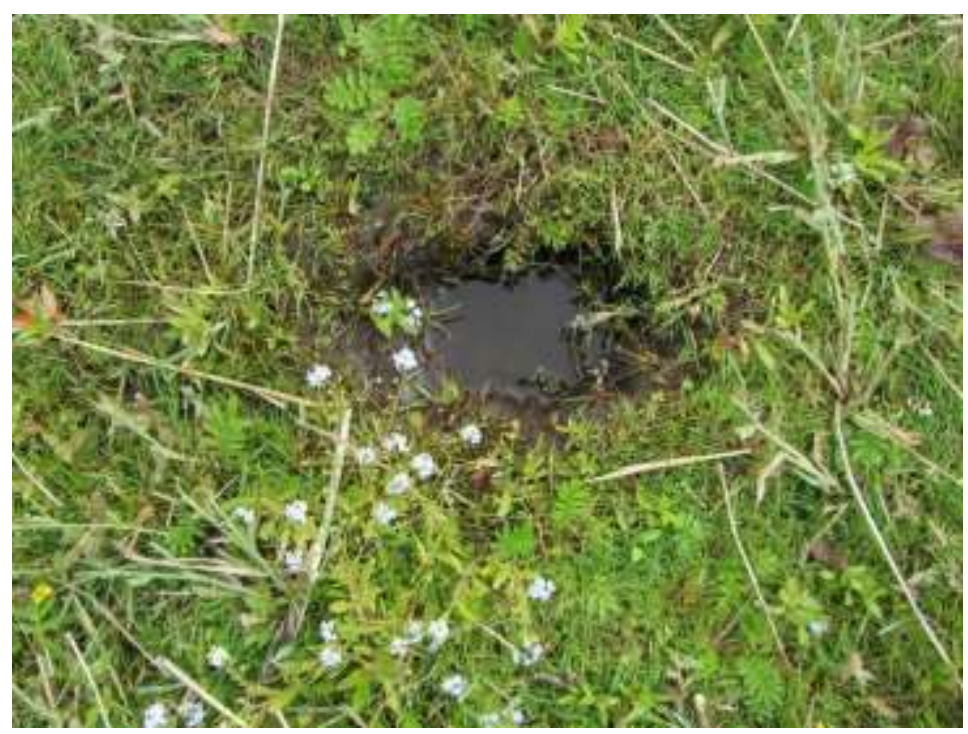




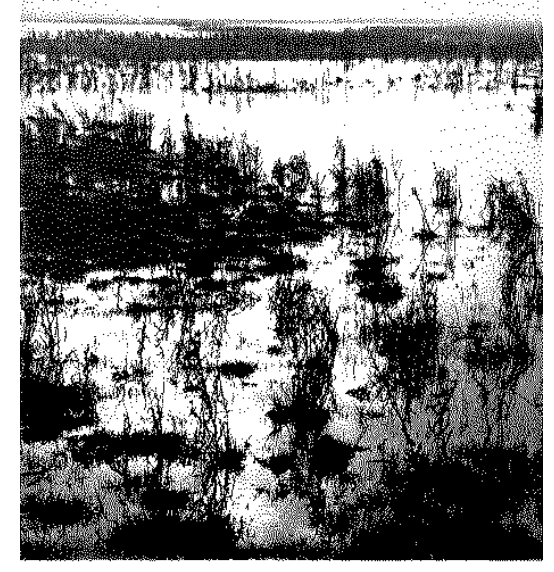

de wopkumerwaapd
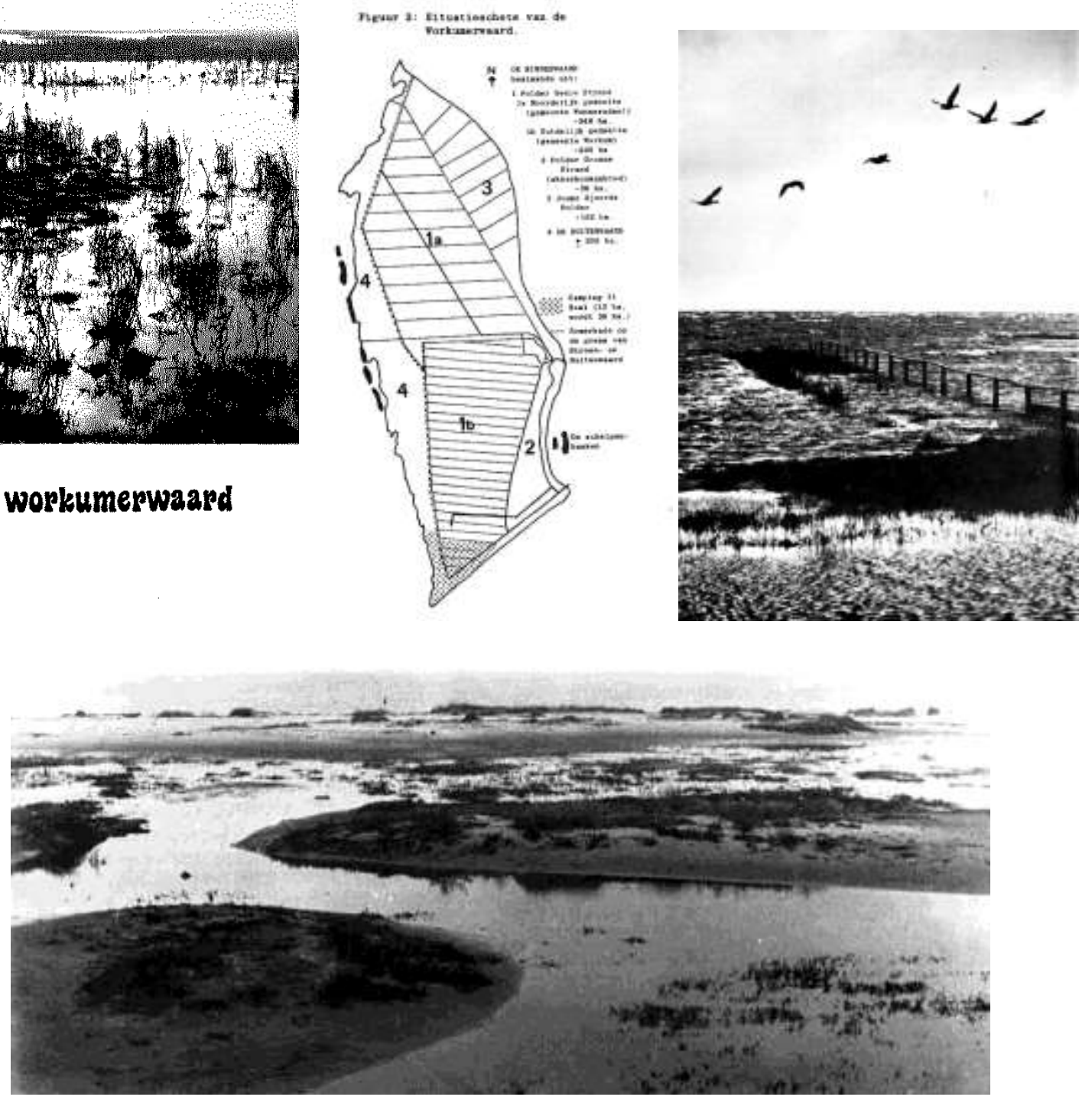

Winter aspect of the vegetation in the Buitenwaard (foreland)

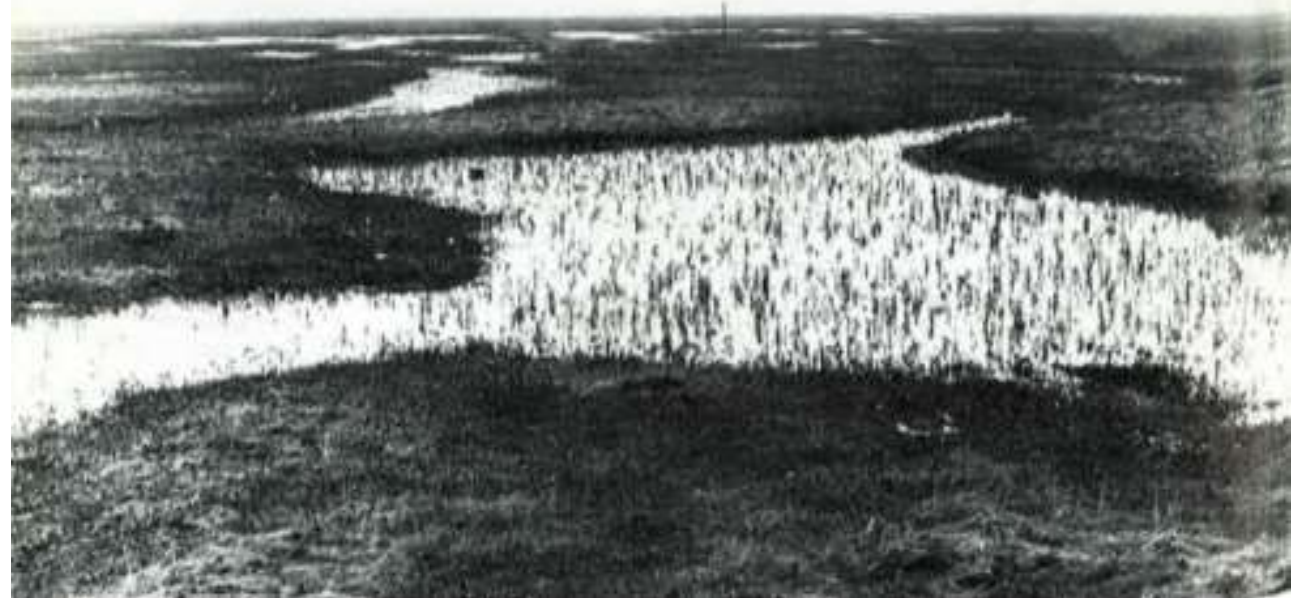

Vegetation with Hippurus vulgaris (Lidsteng) in the Buitenwaard (foreland)

All information (section 5) and photos from Bakker et al (1978). 


\section{VEGETATION DEVELOPMENT IN A HISTORICAL PERSPECTIVE}

Before the construction of the Afsluitdijk, the area of the present Binnenwaard (nowadays a complex of intensively and extensively used meadows) was characterised by clay soils, while the area of the present Buitenwaard was characterised by sandy soils. Sandy salt marshes were dominated by species such as Puccinellia sp., Glaux maritima, Limonium vulgare, Honkenya peploides, Aster tripolium. After the construction of the Afsluitdijk, a large sand bank had developed in the place of present Workumerwaard and was overgrown by Salicornia europea and Suaeda maritima. Reclamation of Workumerwaard started in 1934.

A survey of the Workum Buitenwaard from the 1970-ties emphasized the high environmental dynamics in the area (see photos opposite page). A temporary flooding in winter and spring during storms with strong southwest winds was common. Elongated sand and shell banks were formed and have been elevated due to sediment transport during storms and by drifting ice. Due to the high winter water levels, the shell banks were often flooded and remained bare in early spring. The area was characterised by presence of shallow, muddy pools with stagnating water and no vegetation. The area was grazed with cattle and occasionally with horses. Due to the variation in soil because of calcareous sea sand, pockets of clay deposits and organic peaty soils, enhanced by a rich land relief (a remnant of the salt marshes), the vegetation was also diverse. The lowest parts were overgrown by tall marsh vegetation, while higher parts were covered with grass swards.

Over 200 plant species were observed in the area. Some rare species reported in the late 1970-ties included: Scirpus rufus, Eleocharis quinqueflora, Orchis incarnata (=Dactylorhiza incarnata). In the moist and wet grassland species such as Caltha palustris, Pedicularis palustris were found, with a regular occurrence of Oenanthe lachenalii, Samolus valerandii, and sporadically Orchis praetemissa. Species-rich marsh vegetation included species: Butomus umbellatus, Sium latifolium, Peucedanum palustre, Valeriana officinalis, Lythrum salicaria, Aster tripolium and Sonchus palustris. Nowadays, many of these species are not - or rarely - observed. In well-developed AgropyroRumicion crispi vegetation, Triglochin palustris, Eleocharis palustris, Stellaria palustris and Rumex crispus were abundant. Sand banks were scarcely overgrown by Sedum acre.

Although some juvenile Potamogeton pectinatus were present, the large patches of this species had disappeared already than. In the channels and pools with silty and muddy deposits species such as Hippurus vulgaris, Zannichellia palustris and Myriophyllum spicatum were found. Salt-tolerant species were reported, mainly in the northern part of the area,: Plantago coronopus, Glaux maritima, Trifolium fragiferum, Spergularia marina, Armeria maritima, sporadically Salicornia europaea. 

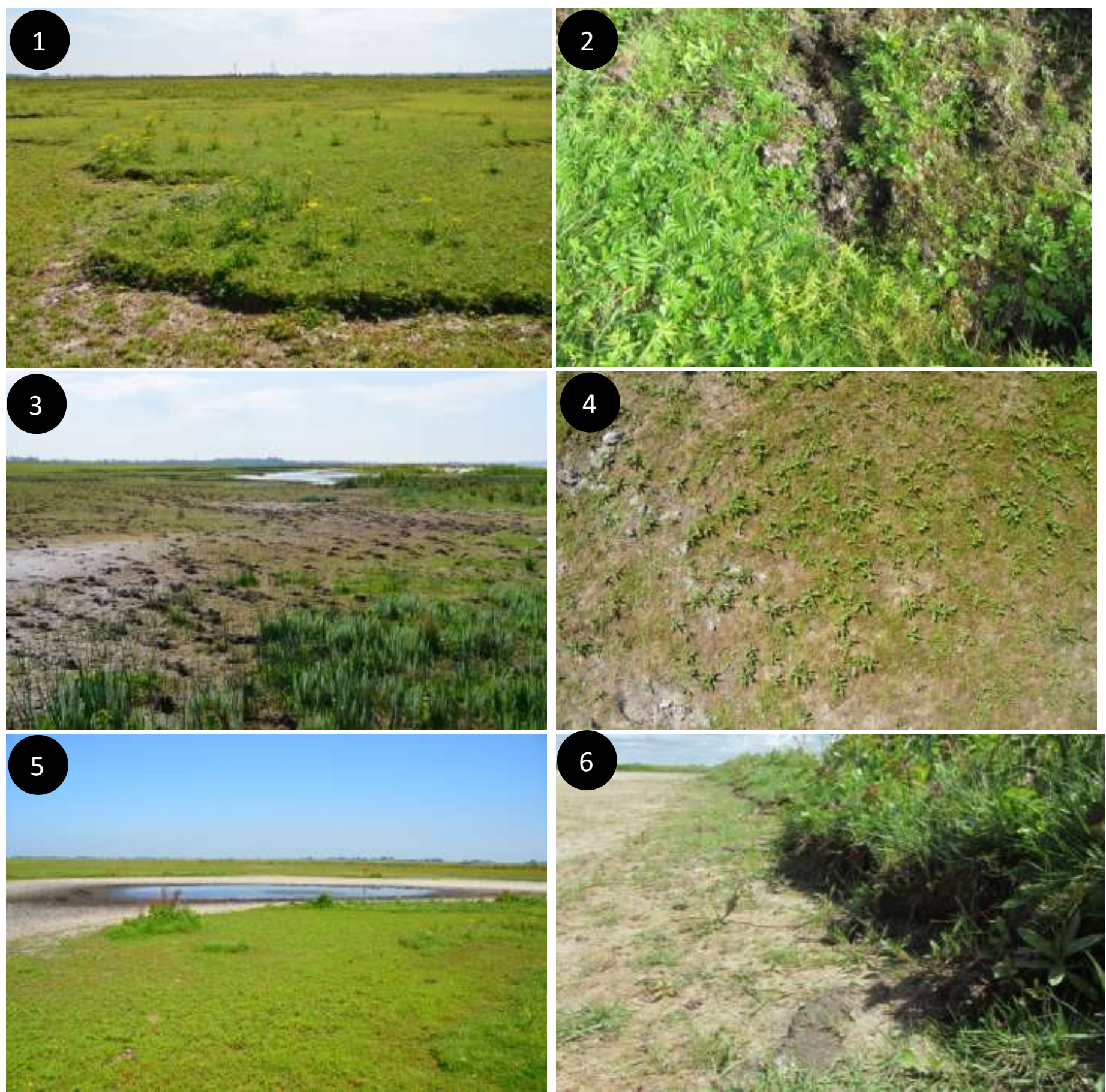

Patterns of soil erosion and formation of shallow pools (photo 1,5 ), dieback of the vegetation after inundation (photo 2,4 ), erosion edges of the puddles (photo 1, 6), trampling of the soft soil (photo 3 ) (C) A. Klimkowska 2015 
Forming of shallow pools and puddles, which is taking place inlands (>20 $\mathrm{m}$ from the shoreline), especially in the southern part of the monitored area, seems to be progressing quickly. It was addressed already in 2012, but it appeared to advance since then and transformed large parts of the former wet meadows. While sedimentation of new deposits takes place in the zone close to the shore and mainly in winter/early spring, the high water tables, causing inundation of wet meadows inland occur regularly in summer. The network of shallow pools expanded probably due to a dieback of the vegetation during long-term inundation (anoxic conditions in the soil) in the growth season combined with soil erosion due to waves in shallow water. This process leads to a loss of area and quality of the existing wet meadow habitat (breeding and foraging areas for birds), as well as it results in washing away the shallow organic soil layer, eventually leading to exposition of bare and loose sand material. This development can make the area less resilient to further soil erosion, speed up the disappearance of large parts of the forelands and, consequently, lead to a decrease of the flood protection function.

In the evaluation based on the root density (2011), the short and inundated vegetation in shallow pools had the lowest rooting densities and, therefore, the least erosion resistance. The ongoing forming and extending of pools is also supported by an increase in species indicative for pioneer conditions: small, often annual, germinating on bare, muddy soils (observed in 2012 and in 2015). These species benefit from the soil disturbances in the soft, moist, organic or silty soils. This increase was most likely related to the intensive grazing and trampling by cattle: e.g. after an intensive grazing in 2011, such plants were observed mainly in the hoof prints in the moist, organic soil. An increase in species indicative for brackish conditions and wet, muddy soil was also observed in 2015 (see Fig. 4.12).

Although cattle grazing in not the main cause of this problem, it can accelerate the erosion if the root development has deteriorated, due to trampling and a consequent heavy soil disturbance. Normally the root biomass in such a grass vegetation is substantially greater than the aboveground biomass (Bekisa 2012). Plants that experience a strong anoxia stress in the root zone and additionally experience temporary high grazing, are weakened and cannot effectively re-grow or re-establish within a relatively short period of time when the growth conditions are good. However, bare, muddy soil also offers an opportunity for germination (e.g. from the soil seed bank) for some early succession species that are uncommon elsewhere, e.g. Eleocharis acicularis, Pulicaria vulgaris, Limosella aquatica. In the past, the muddy pools and temporary flooding of meadows were present, although the inundation was mostly in winter; while water levels in summer were lower (see section $5)$. 

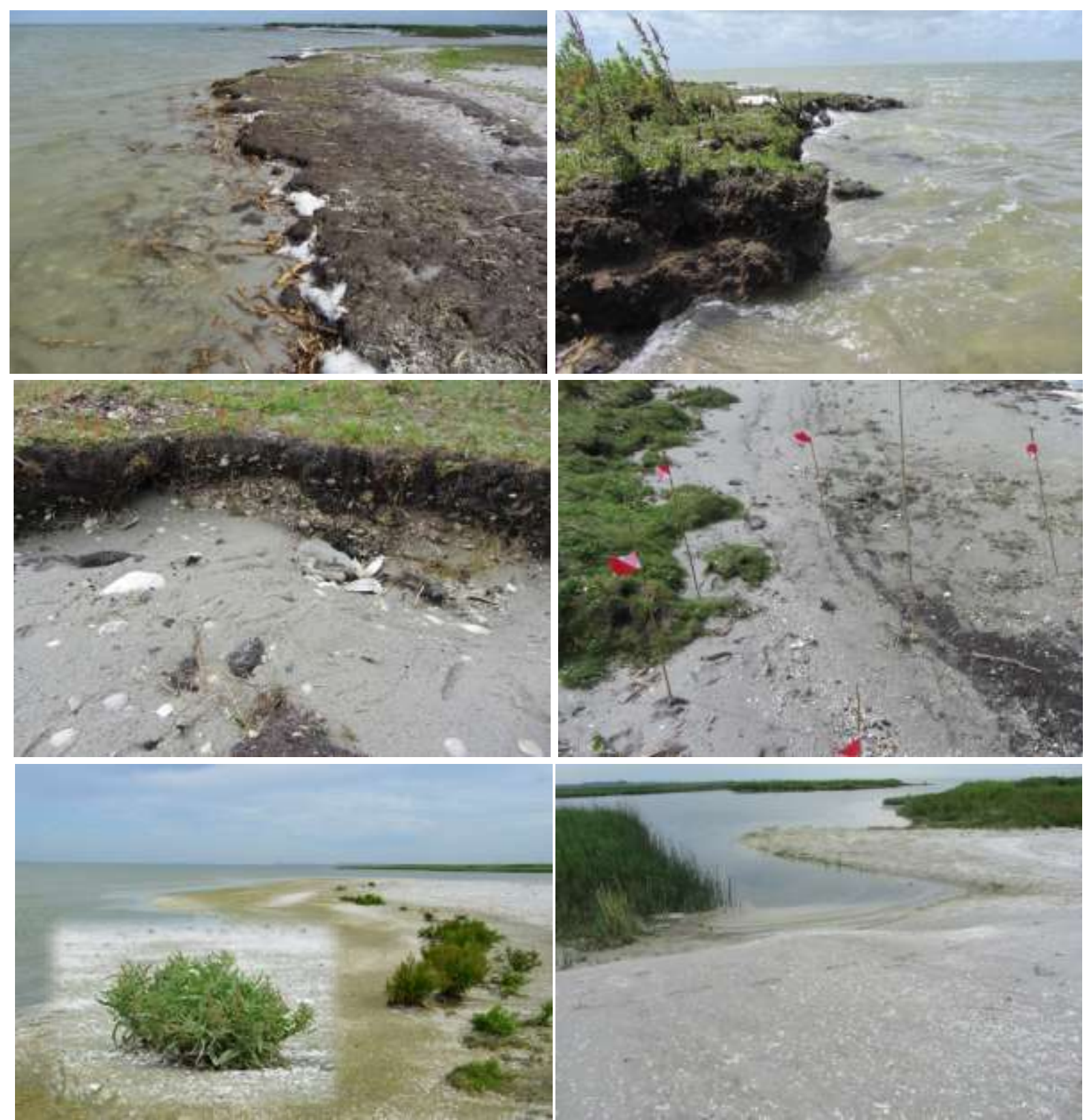

Erosion on the coast due to wave actions and re-deposition of the material (bottom row)

(C) A. Klimkowska 2015 
Recent shore erosion was observed in 2015. Shallow soil that developed in past 70 years is being eroded away and the shoreline slowly retreats. In addition, exposition of peat-like deposits, with remnants of root and rhizomes of reed on the lakeshore indicated constant erosion. The sand and shallow soil on the border between the sand shore and established vegetation was washed away during recent storms. This indicated that erosion takes place on not only shell banks, but also further inland. Vegetation in coastal areas can act as an ecosystem engineer e.g. by fixing the sediment with roots and reducing the erosion rates, particularly in the case of low aboveground biomass (Borsje et al. 2011). In the monitored area it seems that the "ecosystem engineering" effect of the vegetation: preventing the erosion and keeping the shallow soil in place, is only possible under moderate (wave) erosion pressure. The erosion processes seems to be stronger in the southern part of the monitored area and the erosion resistance of the vegetation is low (varies from moderate to bad) (Klimkowska et al 2012).

Also, formation of new shall banks and filling up of the gullies was observed in 2015: the shallow water between a former 'island' and the main forelands was filled up by course sand and shell deposits (vicinity of $L 51, L 53$ ); some vegetation (mainly Rumex sp.) was found on the shell bank located ca. $50 \mathrm{~m}$ from the shoreline inward (vicinity of transect 4); in the southern part of the area (vicinity of transect 3), a deep gully was closed from the lake with the fresh shell banks (visible on the aerial image from 2011).

All three processes can be also observed on the aerial photographs of the area (e.g. via Google Earth), especially if the image from 2005 is compared with the image from 2015. 


\section{SYNTHESIS}

The aim of the project was to evaluate the effectives of the 'soft sand engine' located on Frisian Lake IJssel shore. The secondary objective was to gather information on the system and its response to the applied measures, in order to develop better adaptation strategies in the future. Due to the low dynamics of the system (i.e. absence of tidal movement), the dynamics of sediment deposition was predicted to be low. In general, an increase of the elevation due to more sediment deposition and subsequent changes in the vegetation were expected. The terrestrial part of the Workumerwaard was monitored for changes in vegetation. Parallel, information on the elevation height and vegetation structure was collected. The results of the monitoring were evaluated after 1 year and after 4 years since creation of the sand nourishment in 2011. Overall, the elevation within the vegetation did not show the expected change.

In 2012, a tendency for a small increase of the elevation was observed, but this was still within the error range of the measurement accuracy and was discarded as unreliable. In 2015, dynamic changes in the shell bank zone and shifting of these banks were observed: a large decrease or moderate increase of the elevation. Further inland though, no change or decrease of the elevation was found. For some vegetation types: mainly in short wet meadows and drier meadow type, the decrease of land height was considerable.

The processes of erosion and deposition of sediment varied among the transect locations, although no consistent differences between control and effect transect can be concluded. In general, some gains in the elevation were recorded in the shore zone in the northern part of the area, while in the rest of the area no change or decrease of the elevation was found. These changes cannot be clearly ascribed however, to sediment transport and the effect of sand nourishment or the 'eco-dynamic' dam. The results of the land morphology and bathymetry monitoring are not supporting this.

Based on the analysis of the vegetation it was concluded that the vegetation in the area is mainly driven by hydrological factors and by the occurrence of soil disturbance, due to both sedimentation and erosion, or is related to grazing. The effect of the sand nourishment on the vegetation composition was expected in the vegetation close to the shore: vegetation on the shell banks (sb), tall vegetation of the marsh zone on the coast (tv) or vegetation in the ditches ( $w$ ), just behind sand banks, and to a lesser extent in mosaic vegetation $(\mathrm{m})$, slightly further from the shoreline. Overall, no clear effect of the sand nourishment on the vegetation composition has been found. The changes (if any) that were found in these vegetation types were related to erosion and decrease of elevation (sb) or autonomous processes in the area (influence of grazing or overgrowing of the ditches), rather than to the sand nourishment.

The change of the vegetation on the sand banks was related to dynamics of the sediment, mainly erosion. Due to lower dynamics, some plots were overgrown by ruderal plants species.

The changes in the short, wet meadow vegetation were most likely related to prolonged inundation (formation of shallow pools), and secondary to grazing and trampling of the soft soils, due to the high grazing pressure. The trampling and poorly developed sward that is wakened by prolonged inundation results in soil disturbances and patches of bare soil, which provide space for pioneer, often short-living plants and small, low-competitive species. The results of the vegetation structure analysis indicated that the variability was naturally high in the study area and no clear difference 
over time was found. The vegetation structure was probably strongly controlled by grazing that varied in pressure and grazing period.

The patches of tall vegetation with reed and rushes contribute to a higher soil erosion resistance, due to accumulation of belowground biomass, roots deeper in the soil, while grasses or meadow herbs usually do not have extensive belowground structures and only have shallow roots that extend horizontally near the soil surface (Bekisa 2012). Taller and rougher vegetation slows down the current velocity, reduces wave energy and traps sediments more effectively than short vegetation (Borsje et al. 2011). Maintaining a gradient with a mosaic of tall and short vegetation supports best the function of soil erosion prevention, due to differences in allocation of biomass above- and belowground biomass.

There was no clear effect of the sand nourishment on the vegetation in this pilot, even after 4 years. However, this project provided valuable information, helped to identify the erosion processes and documented different developments in the area. This contributed to a better understanding of the vegetation development and the potential for adaptation measures.

The detected changes in the vegetation are partly consistent with the results if the analysis in 2012 . The strong impact of the hydrological conditions on vegetation, the impact of grazing (especially trampling), and variation in the vegetation of the shell banks, due to the dynamics of the sediment (mainly erosion), were already indicated after first year of the pilot (2012). In the current analysis, these patterns were confirmed and in addition, change due to soil erosion inland was demonstrated. Given the dynamics of the changes and the continuous transformation of the vegetation related to the soil erosion inland, it is recommended to continue the monitoring in the same way, with a low frequency of observations (once every 3-5 years).

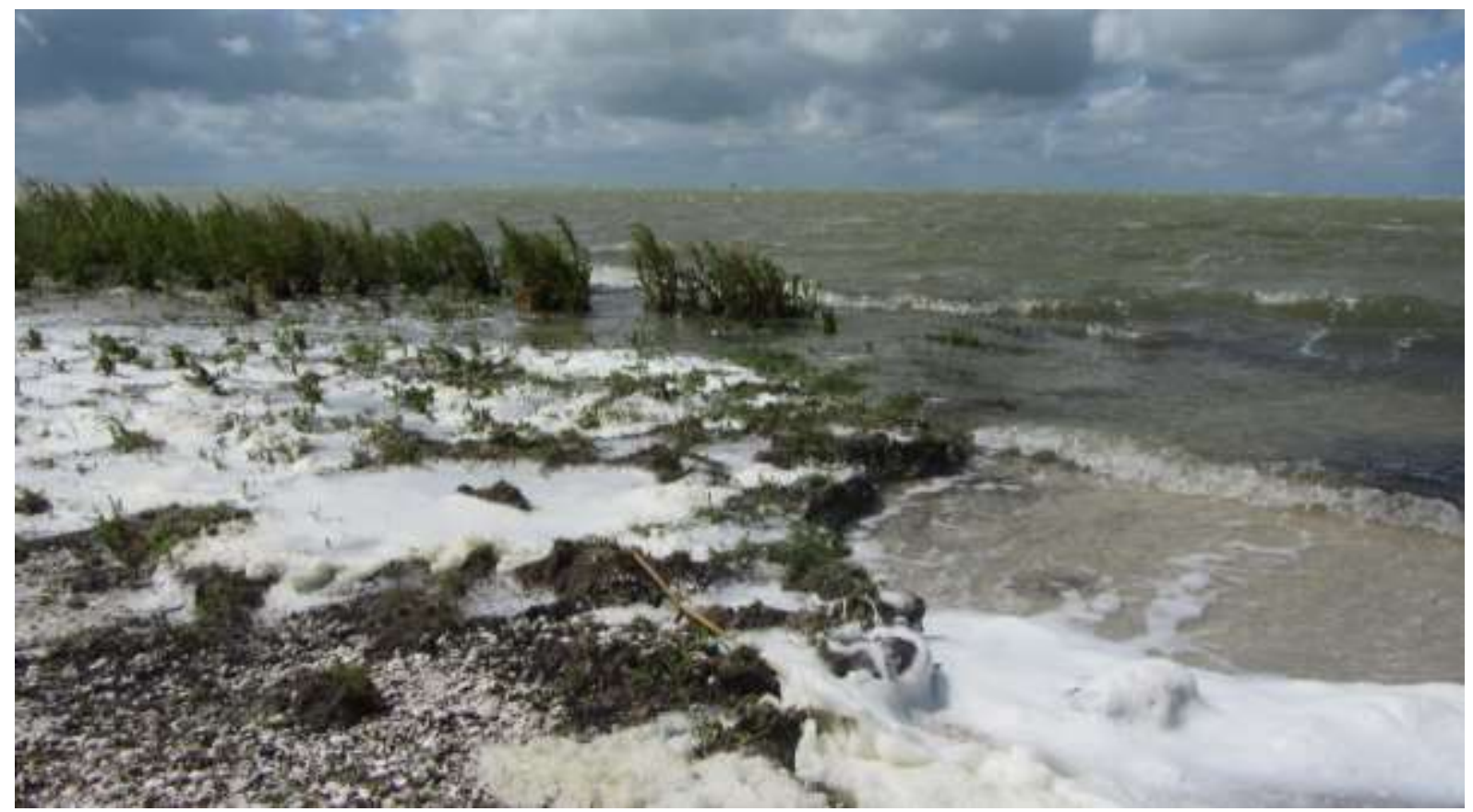

Eroding shore of the lake exposed to the waves (C) A. Klimkowska 2015 


\section{LITERATURE}

Bakker, S., Bouma, P., van Duin, G., Philippona, J., Sjouken, R., Tanger, D., Zomerdijk, P., 1978. De Workumerwaard. Watervogels Mei 1978.

Bekiša, B. 2012. Quantitative evaluation of root biomass and small fauna in Workumerwaard for assessing main functions of this system: erosion prevention and provision of food for breeding birds. Internship project report Stichting Bargerveen, Radboud University Nijmegen, Nijmegen 2012. Available on request from Agata Klimkowska

Brosje B.W., van Wesenbeeck B.K., Dekker F., Paalvast P., Boums T.J., van Katwijk M.M. \& de Vries M.B. 2011. How ecological engineering can serve in coastal protection. Ecological Engineering, 37, 113-122.

Klimkowska A., Wegman R \& Dobben H. 2011. Effects of pilot eco-dynamical design 'sand engine' on the vegetation of Workumer Buitenwaarden, Frisian IJsselmeer coast. Monitoring set-up. Report of the terrestrial vegetation study. Alterra, 28. pp.

Klimkowska, A., Dobben, H, Wegman, R. 2012. Monitoring of effects on the shore vegetation of a sand engine in Lake IJssel, offshore Workum. Results of the terrestrial vegetation monitoring 2011-2012. Eco-Shape Report.

Leps, J., Smilauer, P., 2003. Multivariate analysis of ecological data using CANOCO. Cambridge University Press, New York. 


\section{SUPPLEMENTS}

\section{SUPPLEMENT A}

Location of the PQs (red dots) in the northern (first image) and southern (second image) part of the study area, projected on the high-resolution aerial photograph of the Workumerwaard, taken in early spring 2011 for this monitoring project (from Klimkowska et al 2012).

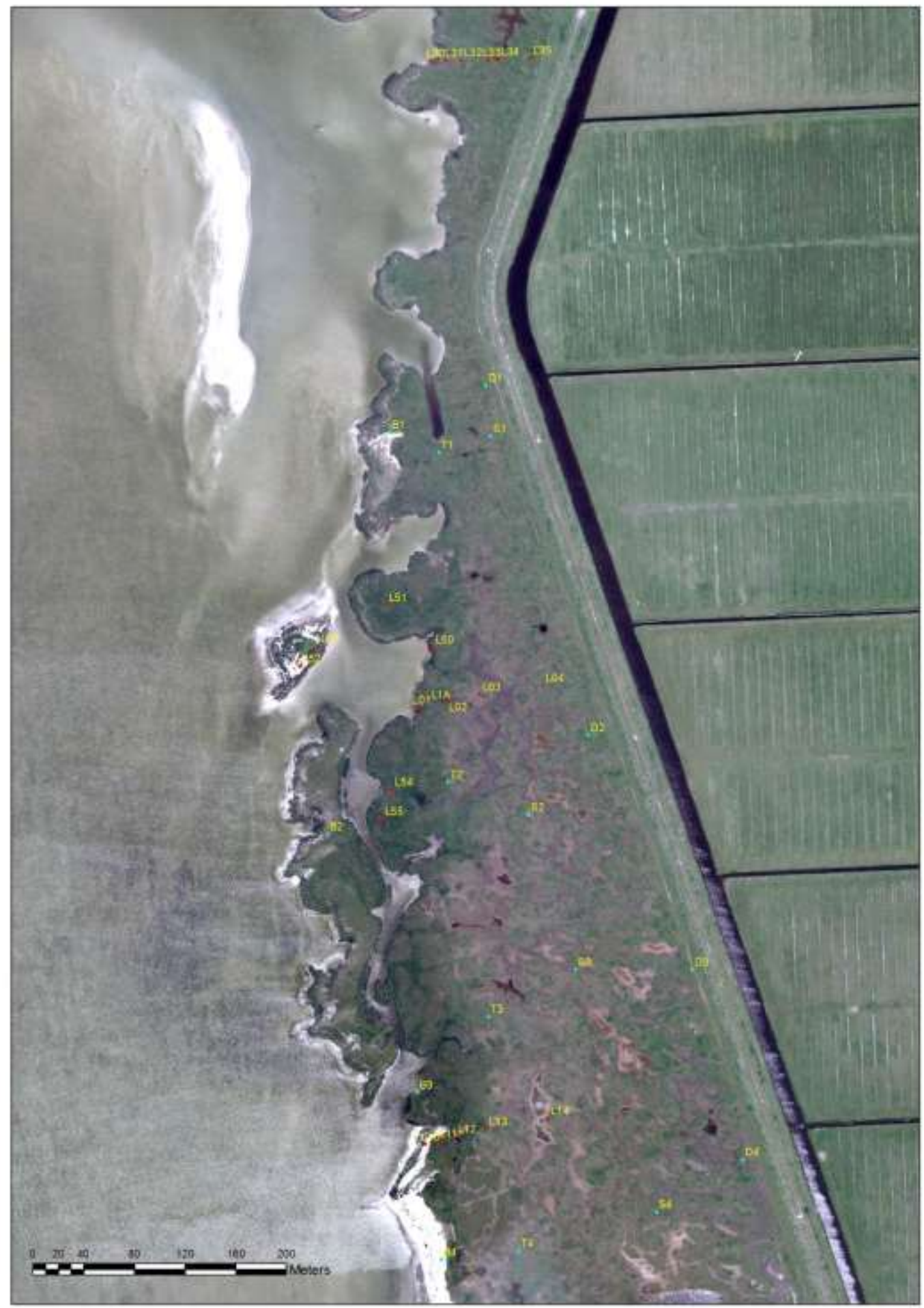




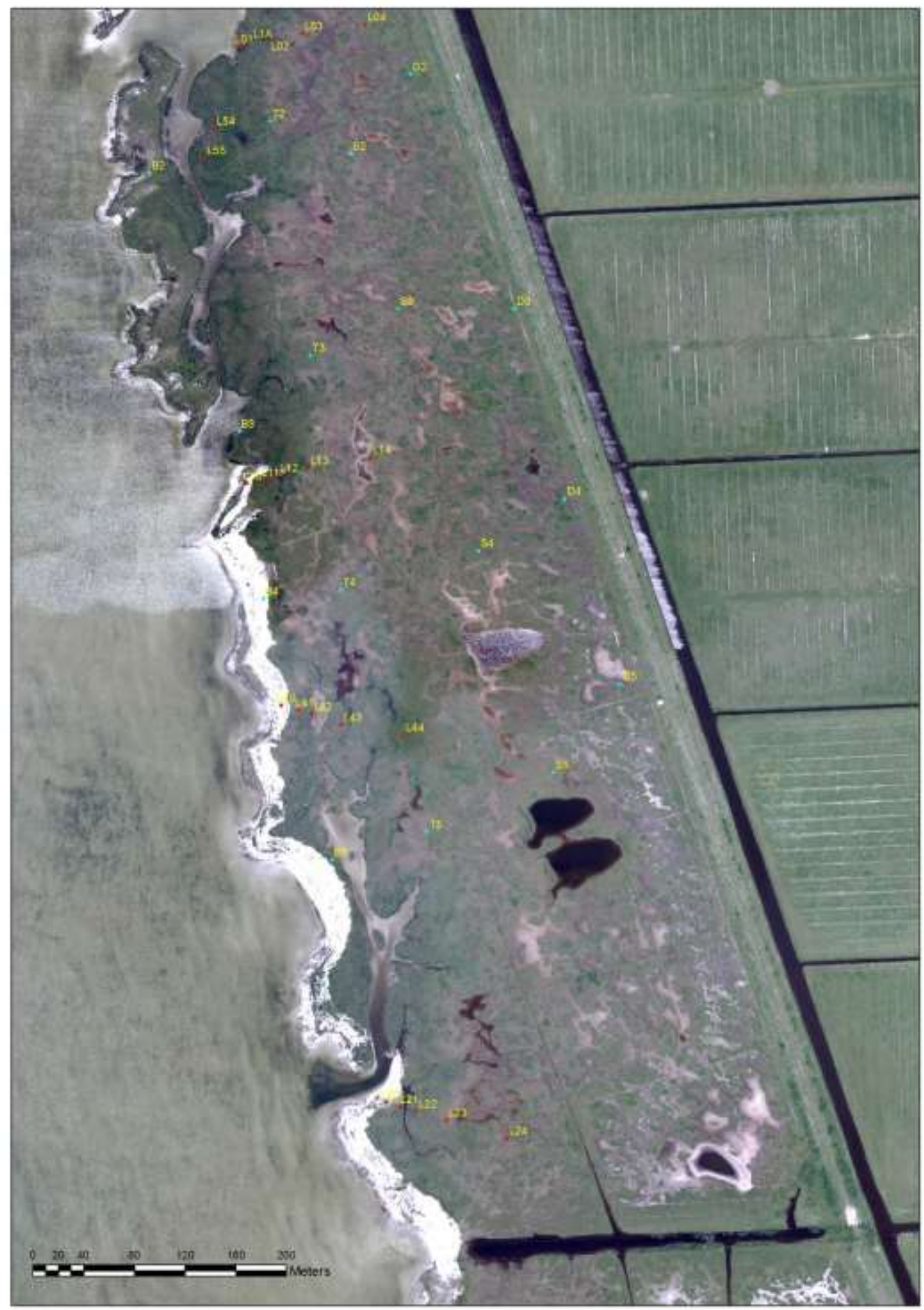




\section{SUPPLEMENT B}

The coordinates of the PQ plots. The elevation measurement of 2015 are provided in the digital format (excel sheet).

\begin{tabular}{|c|c|c|c|c|}
\hline No. & Plot ID & Coordinates RD-X & Coordinates RD-Y & transect \\
\hline 1 & L01 & 155818.89 & 556540.65 & transect 1 \\
\hline 2 & L01A & 155828.07 & 556544.97 & transect 1 \\
\hline 3 & L02 & 155841.75 & 556546.23 & transect 1 \\
\hline 4 & L03 & 155868.57 & 556551.02 & transect 1 \\
\hline 5 & LO4 & 155918.29 & 556558.06 & transect 1 \\
\hline 6 & L10 & 155825.01 & 556196.04 & transect 2 \\
\hline 7 & L11 & 155837.14 & 556198.97 & transect 2 \\
\hline 8 & L12 & 155849.09 & 556202.29 & transect 2 \\
\hline 9 & L13 & 155873.30 & 556208.11 & transect 2 \\
\hline 10 & L14 & 155922.17 & 556216.57 & transect 2 \\
\hline 11 & L20 & 155934.82 & 555707.46 & transect 3 \\
\hline 12 & L21 & 155946.16 & 555704.06 & transect 3 \\
\hline 13 & L22 & 155958.51 & 555700.59 & transect 3 \\
\hline 14 & L23 & 155982.47 & 555693.43 & transect 3 \\
\hline 15 & L24 & 156030.35 & 555679.17 & transect 3 \\
\hline 16 & L30 & 155829.50 & 557051.10 & transect 4 \\
\hline 17 & L31 & 155841.67 & 557051.15 & transect 4 \\
\hline 18 & L32 & 155853.84 & 557051.55 & transect 4 \\
\hline 19 & L33 & 155874.84 & 557051.70 & transect 4 \\
\hline 20 & L34 & 155882.92 & 557052.28 & transect 4 \\
\hline 21 & L35 & 155908.49 & 557053.53 & transect 4 \\
\hline 22 & L40 & 155851.92 & 556020.84 & transect 5 \\
\hline 23 & L41 & 155865.40 & 556017.12 & transect 5 \\
\hline 24 & L42 & 155875.90 & 556014.16 & transect 5 \\
\hline 25 & L43 & 155899.37 & 556005.62 & transect 5 \\
\hline 26 & L44 & 155948.39 & 555997.25 & transect 5 \\
\hline 27 & L50 & 155831.08 & 556588.01 & loose punten nabij L1 \\
\hline 28 & L51 & 155794.33 & 556621.50 & loose punten nabij L1 \\
\hline 29 & L52 & 155726.35 & 556573.37 & loose punten nabij $L 1$ \\
\hline 30 & L53 & 155740.43 & 556588.85 & loose punten nabij L1 \\
\hline 31 & L54 & 155798.95 & 556476.09 & loose punten nabij L1 \\
\hline 32 & L55 & 155791.56 & 556452.90 & loose punten nabij L1 \\
\hline
\end{tabular}


SUPPLEMENT C

Reclassification of the abundance data for multivariate analysis.

\begin{tabular}{|ccc|}
\hline Abundance species & $\%$ & Averaged for analysis \\
\hline$r$ & rare, $<1 \%$ & 0.1 \\
\hline+ & few, $<5 \%$ & 2 \\
\hline 1 & abundant, $<5 \%$ & 3 \\
\hline $2 m$ & numerous, $<5 \%$ & 4 \\
\hline $2 a$ & $5-12.5 \%$ & 8 \\
\hline $2 b$ & $12.5-25 \%$ & 18 \\
\hline 3 & $25-50 \%$ & 38 \\
\hline 4 & $50-75 \%$ & 68 \\
\hline 5 & $75-100 \%$ & 88 \\
\hline
\end{tabular}




\section{SUPPLEMENT D}

Vegetation typology (Klimkowska et al. 2011):

- $\quad$ Type 1: sparse vegetation on bare sand or shell banks with Sedum acre and Tripleurospermum maritimum (4 relevés: $13,18,24,33^{*}$ )

- $\quad$ Type 2: vegetation in ditches, or vegetation dominated by Hippurus vulgaris and Eleocharis palustris, (3 relevés: $7,15,16^{*}$ )

- Type 3: tall vegetation dominated by reed Phragmites australis or Schoenoplectus tabernaemontani, Scirpus maritimus, with wetland species such as Mentha aquatica, Rorippa nasturtium-aquaticum (7 relevés: $\left.3,9,20,23,26,30,35^{*}\right)$

- Type 4: vegetation dominated by Agrostis stolonifera with co-dominance of Carex nigra, Juncus gerardii, Potentilla anserina ( 6 relevés: $8,11,12,17,27,28^{*}$ )

- Type 5: meadow (a drier type) vegetation with grasses: Festuca rubra, Holcus lanatus, Agrostis stolonifera, and herbs Dactylorhiza majalis, Pulicaria dysenterica, and Plantago lanceolata (5 relevés: 4,5,6,10,31*)

- Type 6: mixed (mosaic) vegetation with dominance of Agrostis stolonifera, with low density of taller plants: Schoenoplectus tabernaemontani, Scirpus maritimus, and some other indicators of brackish conditions (7 relevés: $14,19,21,25,29,32,34 *)$

* Original Turboveg coding 


\section{SUPPLEMENT E}

Details of the CCA analysis of the effect of time on the vegetation types. Partial variation in CCA was 2.07691; explanatory variables accounted for 30.4\% (adjusted 14.3\%). Eigenvalues of the first four axes: 0.1362, 0.0910, $0.0777,0.0694$. Explained variation (cumulative) on the first four axes is $6.56,10.94,14.68,18.02$. Term of simple effects (from Monte Carlo permutation test, 999 permutations):

\begin{tabular}{|c|c|c|c|c|c|c|c|}
\hline Name & $\begin{array}{l}\text { Explains } \\
\%\end{array}$ & pseudo-F & $\mathbf{P}$ & Name & $\begin{array}{l}\text { Explains } \\
\%\end{array}$ & pseudo-F & $\mathbf{P}$ \\
\hline 2015*sb & 4.2 & 2.8 & 0.005 & $2012 * m$ & 2.3 & 1.5 & 0.091 \\
\hline $2012 * s b$ & 3.9 & 2.5 & 0.013 & $2015 *$ tv & 2.3 & 1.5 & 0.067 \\
\hline 2011*sv & 3.8 & 2.5 & 0.004 & $2011 *$ tv & 2.1 & 1.4 & 0.112 \\
\hline 2011*sb & 3.5 & 2.3 & 0.015 & $2011 * d m$ & 1.7 & 1.1 & 0.272 \\
\hline $2015 * m$ & 3.4 & 2.2 & 0.003 & $2015^{*} \mathrm{dm}$ & 1.7 & 1.1 & 0.293 \\
\hline $2015 * w$ & 3.3 & 2.1 & 0.02 & $2012 * s v$ & 1.4 & 0.9 & 0.558 \\
\hline 2011*m & 3.2 & 2.1 & 0.006 & $2012 *$ tv & 1.2 & 0.8 & 0.717 \\
\hline 2015*sv & 2.8 & 1.8 & 0.018 & $2012 * w$ & 1.1 & 0.7 & 0.732 \\
\hline $2011 * w$ & 2.7 & 1.7 & 0.066 & $2012 * d m$ & 1.1 & 0.7 & 0.831 \\
\hline
\end{tabular}

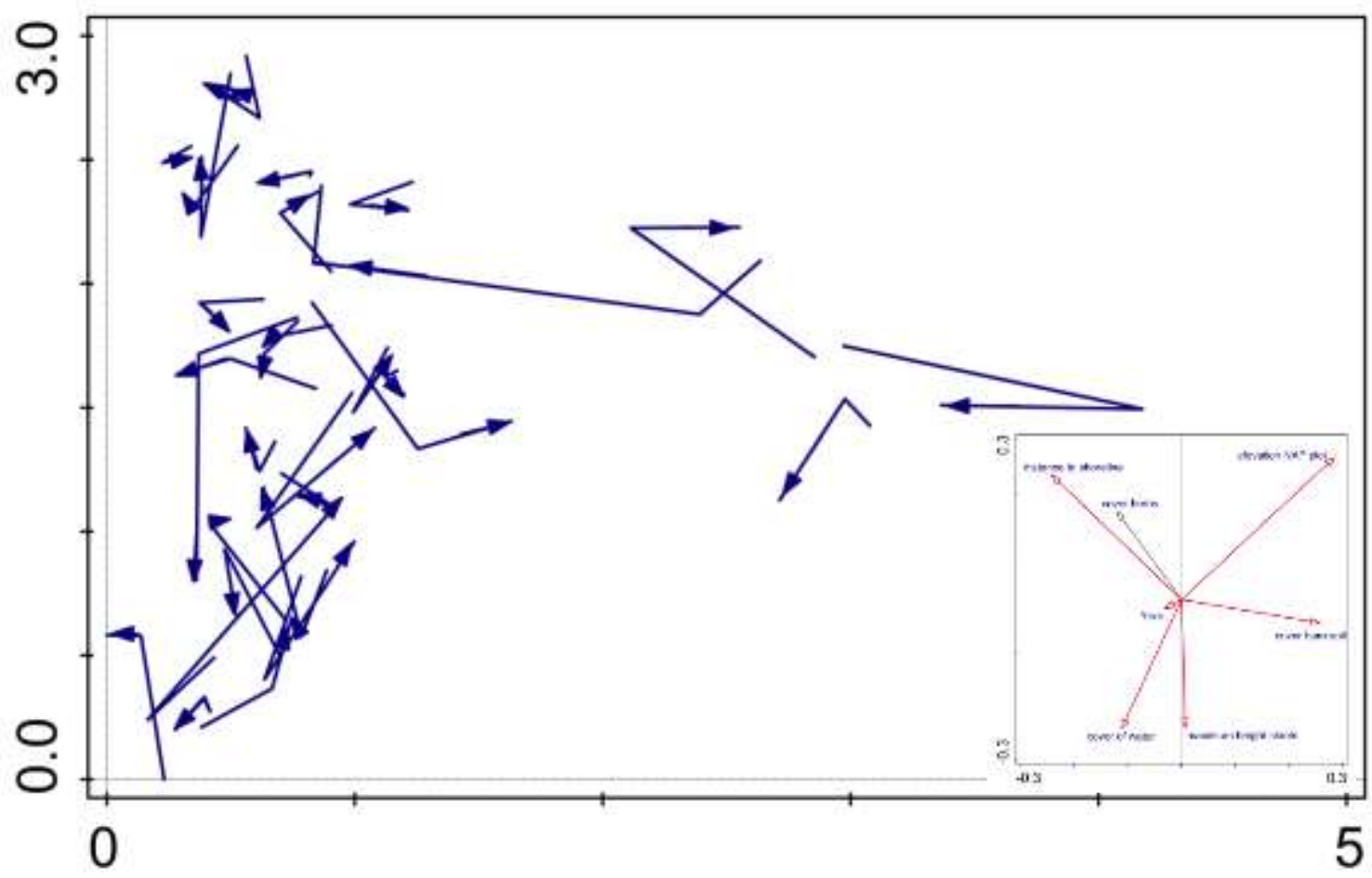

Figure E: Displacement of the plots (PQs) in the DCA ordination space over time. Arrows indicate location of each permanent plot and its shift over time. Statistical sig. was not tested for each plot. Graph illustrates that some plots changed considerable, but in many cases plots of the same vegetation types 'moved' in the opposite directions. 